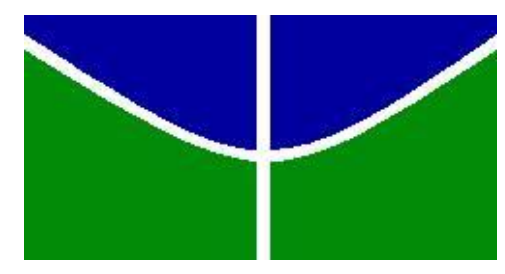

UNIVERSIDADE DE BRASÍLIA

FACULDADE DE EDUCAÇÃO FÍSICA

PROGRAMA DE PÓS-GRADUAÇÃ̃O STRICTU-SENSU EM EDUCAÇÃO FÍSICA

JORGE ADILSON GONDIM PEREIRA

FORMAÇÃO EM EDUCAÇÃO FÍSICA: DISCURSOS E A PRÁTICA CURRICULAR 


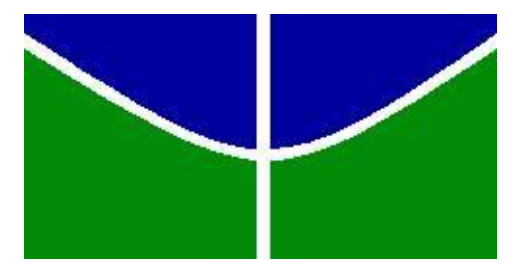

JORGE ADILSON GONDIM PEREIRA

\title{
FORMAÇÃO EM EDUCAÇÃO FÍSICA: DISCURSOS E A PRÁTICA CURRICULAR
}

Dissertação apresentada à Faculdade de Educação Física da Universidade de Brasília como requisito parcial à obtenção do título de Mestre em Educação Física.

\section{Orientador: Dr. Lino Castellani Filho}

\author{
Brasília - DF
}

2014 


\section{DEDICATÓRIA}

Dedico esse trabalho ao meu pai Everardes Marques Pereira (in memorian), como forma de agradecimento a todo esforço que fez em vida pela educação dos seus filhos. Com ele, não aprendi nada sobre ciência, porém, ajudou a tornar-me um ser humano bem melhor. 


\section{AGRADECIMENTOS}

Agradeço primeiramente a Deus por ter me dado forças para resistir às adversidades e obstáculos típicos de um mestrando em idade madura, com filhos em idade escolar e uma série de responsabilidades que nem sempre conseguimos assumir tendo em vista a distância e para persistir no desenvolvimento desse trabalho.

Embora a produção de uma dissertação exiga esforço individual e isolamento como condições essenciais ao desenvolvimento da escrita textual, o processo formativo que antecede esse produto é perpassado também por encontros, atividades e experiências coletivas que, sem dúvida alguma, determinam o amadurecimento das nossas ideias e o enriquecimento do trabalho.

Assim, gostaria de demonstrar a minha gratidão com todos aqueles que direta ou indiretamente contribuiram comigo ao longo dessa caminhada. Inicio pela minha esposa Andréia e minhas filhas Flávia e Roberta pelo apoio e compreensão. Agradeço também a minha querida mãe pela sua preocupação e orações por ocasião das minhas viagens a Brasília. Aos meus irmãos Maria de Lourdes, Welton, Marco e Emerson pelo apoio à minha família durante as minhas ausências.

Agradeco especialmente ao meu orientador, Prof. Dr. Lino Castellani Filho, pela contribuição na minha formação, pelas lições de humildade e solidariedade e por ter me concedido a honra de ser seu orientando.

Agradeço a todos os membros do AVANTE, grupo de pesquisa que me acolheu e me ajudou nas reflexões relativas ao meu trabalho. Aos professores Marcelo Húngaro e Fernando Mascarenhas pelos ensinamentos e, sobretudo, pela amizade, companheirismo e acolhimento em Brasília.

Agradeço também os professores José Vieira(FE/UNB) e o professor Nivaldo Nogueira David(FEF/UFG). Este último, fonte de inspiração e de diálogo em torno dos dilemas da formação profissional em Educação Física.

Agradeço aos meus amigos do "baba" e dos encontros "pós-baba" no Bedrock: Juarez, Pedro, Robson, Erick, Tatu, Liáo, Jonatas, Daniel e demais companheiros não citados, pela amizade, discussões e momentos de descontração essenciais à nossa humanização.

Aos meus colegas da pós-graduação Danielle, Willian, Thiago pelo convívio, discussões, interações e pela solidariedade. Ao meu ex-aluno Nadson pelo seu exemplo de luta e determinação em seu percurso formativo na graduação e na pós-graduação.

Aos funcionários da Secretaria da Pós-graduação, Alba, Quélbia e Tiago pelo apoio e presteza.

À professora Mariângela Ribeiro pelo incentivo à minha vinda para Brasília e, em seu nome, aos professores e alunos do Curso de Educação Física da UNEB-Campus XII pela compreensão e apoio ao meu processo de formação. 
Finalmente, agradeço aos professores membros da banca pela participação. Não tenho dúvida que as suas notoriedades e expertises intelectuais serão determinantes para a qualidade final deste trabalho, além de ser motivo de orgulho para esse pesquisador. 


\section{EPÍGRAFE}

"Se a aparência e a essência das coisas coincidissem, a ciência seria desnecessária"

Karl Marx 


\section{RESUMO}

Por meio dessa dissertação, investigamos as repercussões das atuais Diretrizes Curriculares, Resoluções CNE/CP n 01 e 02/2002 e 07/2004, sobre o processo formativo da Educação Física. Para tanto, trabalhamos em três frentes: análise histórica da formação profissional em Educação Física; o estado da arte da formação profissional em Educação Física, tendo como referência o debate sobre os currículos construídos a partir da Resolução CFE $n^{\circ}$ 03/87 e as diretrizes curriculares atuais, além de reinterpretar o seu processo de constituição histórica; por último, um estudo empírico sobre a Licenciatura Ampliada do Curso de Educação Física da UNEBCampus XII no município de Guanambi-BA. Utilizamos o materialismo histórico-dialético como princípio orientador do percurso metodológico do nosso estudo, utilizando como técnicas a pesquisa bibliográfica e documental. Nosso objetivo foi aproximar ao máximo da essência do objeto por meio de sucessivas aproximações, identificando nexos e contradições presentes nos "discursos" legais, acadêmico-cientíticos e na experiência concreta da formação em Educação Física. Assim, concluímos, entre outros aspectos, que são poucos os estudos empíricos em relação aos resultados da formação em Educação Física a partir do atual marco normativo; que existem margens para a escolha de competências críticas no processo de formação profissional tanto na licenciatura como nos cursos de Graduação/bacharelado em Educação Física; que é falacioso o embate sobre o divórcio entre a diretriz de graduação/bacharelado com a diretriz da licenciatura. Na verdade elas se complementam, sobretudo, a resolução CNE/CES n ${ }^{\circ}$ 07/2004, quando apresenta a especificidade da Educação Física; que o CONFEF não foi protagonista exclusivo do processo de construção da Diretriz de Graduação da Educação Física e que a participação democrática dos diversos segmentos vinculados à essa área foi fundamental para a criação de um documento mais avançado; que licenciatura ampliada ou unificada não é o mesmo que formação ampliada. A primeira se refere aos campos de intervenção profissional, ou seja, à atuação profissional, e a segunda ao aprofundamento e consistência do processo de formação profissional. Assim, entendemos que a defesa da licenciatura ampliada ou unificada esbarra numa absoluta contradição com aquilo que os seus defensores vêm pregando. Criticam as diretrizes curriculares com o argumento de que empobreceram a formação pelo seu pragmatismo sendo que a licenciatura ampliada ou unificada causaria o mesmo em virtude do seu foco estar voltado para a atuação no vasto mercado da Educação Física; e, por último, que a licenciatura ampliada atualmente em vigor na UNEB de Guanambi apresenta uma configuração equivocada, além de estar desamparada legalmente, tendo como exemplo gritante a divisão do Estágio Curricular Obrigatório em duas modalidades: Estagio Formal e Não Formal.

Palavras-chave: formação profissional; diretrizes curriculares da Educação Física; licenciatura; bacharelado. 


\begin{abstract}
Through this dissertation, we investigate the impact of current Curriculum Guidelines, Resolutions CNE/CP n 01 and 02/2002 and 07/2004 on the formation process of physical education. To this end, we work on three fronts: historical analysis of vocational training in Physical Education; the state of the art training in Physical Education, with reference to the debate on the curriculum built from the CFE Resolution $n^{\circ}$ 03/87 and current curriculum guidelines, and reinterpret its historical development process; finally, an empirical study of the Extended Degree Course of Physical Education UNEB Campus XII in the city of Guanambi BA. We use the historical and dialectical materialism as a guiding principle of methodological course of our study, using techniques such as bibliographic and documentary research. Our goal was to bring the most the essence of the object through successive approximations, identifying links and contradictions in the "speeches" legal, academic and cientíticos and concrete experience of training in physical education. Thus, we conclude, among other things, that there are few empirical studies about the results of training in physical education from the current regulatory framework; that there are margins for the choice of critical skills in vocational training methods in the degree as in undergraduate courses/BA in Physical Education; that is fallacious the clash on the divorce of the guideline undergraduate/bachelor's degree with the directive of the degree. In fact, they complement each other, Overcoat, CNE / CES Resolution $\mathrm{n}^{\circ}$ 07/2004, when special feature of Physical Education; That was not CONFEF exclusive protagonist of the construction process of Graduate Guideline of Physical Education and The democratic participation of several segments linked to area was fundamental to the of creation document most advanced; that increased degree or unified there is the same as training enlarged. The first up, communicate to professional intervention fields, the professional practice, second a by deepening and consistency of vocational training Process. So, we understand what the defense of larger degree or unified coming up absolute contradiction with what their comes defenders preaching. Criticize as curriculum guidelines with the argument to que impoverished training your hair pragmatism Being that a larger degree or unified cause the same in virtue do his being focus turned to the vast market performance in Physical Education; and lastly, that one currently magnified degree in force on the UNEB of Guanambi presents a wrong configuration, addition to be legally helpless, tendon how glaring example the curricular training division required two in terms: Formal Stage and Non-formal.
\end{abstract}

Key-words: vocational training; physical education curriculum guidelines; degree; Bachelor's degree. 


\section{LISTA DE FIGURAS}

Quadro - 1: $\quad$ Currículo de formação em educação física(1939)

Quadro - II: $\quad$ Currículo de formação em Educação Física (1969)

Quadro - III : $\quad$ Currículo de formação em educação física (1987)

Quadro IV: $\quad$ Produção de artigos sobre a formação profissional de 1990 a 2001

Quadro V: $\quad$ Dados sobre a produção relacionada com a formação profissional naRevista Brasileira de Ciências do Esporte

Quadro VI: $\quad$ Dados sobre a produção relacionada com a formação profissional na Revista Movimento

Quadro VII: $\quad$ Dados sobre a produção relacionada com a formação profissional naRevista Pensar a Prática

Quadro VIII: $\quad$ Orientações e aprisionamentos legais em relação às Diretrizes de Formação de Professores

Quadro IX: $\quad$ Produção de artigos sobre a formação profissional de 2002 a 2013

Quadro X: $\quad$ Dados que analisam a produção sobre formação profissional após publicação das Diretrizes Curriculares da Educação Física na Revista Brasileira de Ciências do Esporte

Quadro XI: $\quad$ Dados que analisam a produção sobre formação profissional após publicação das Diretrizes Curriculares da Educação Física na Revista Movimento

Quadro XII: $\quad$ Dados que analisam a produção sobre formação profissional após publicação das Diretrizes Curriculares da Educação Física na Revista Pensar a Prática

Quadro XIII: $\quad$ Comparativo entre as críticas/reivindicações da formação profissional antes e depois das diretrizes curriculares atuais.

Quadro XIV: $\quad$ Estrutura Curricular do Curso de Educação Física da UNEB - Campus XII 


\section{LISTA DE GRÁFICOS}

Gráfico I : Evolução da produção de conhecimento no Curso de Educação Física via TCC.

Gráfico II : Evolução dos trabalhos de tcc por categorias temáticas.

Gráfico III : Abordagem da pesquisa.

Gráfico IV : Abordagem Metodológica da pesquisa.

Gráfico V : Áreas de conhecimento/TCCs.

Gráfico VI : Relação orientador/ área de conhecimento que atua no curso.

Gráfico VII : Área de conhecimento/atuação docente nas ciências Biomédicas.

Gráfico VIII : Área de conhecimento/atuação docente nas ciências sociais e pedagógicas.

Gráfico IX : Nível de formação dos orientadores.

Gráfico X : Nível de formação/Área de conhecimento dos trabalhos de TCC. 


\section{LISTAS DE SIGLAS E ABREVIATURAS}

\begin{tabular}{|c|c|}
\hline $\mathrm{CNE}$ & Conselho Nacional de Educação \\
\hline CES & Câmara de Educação Superior \\
\hline CONFEF & Conselho Federal de Educação Física \\
\hline CREF & Conselho Regional de Educação Física \\
\hline UNEB & Universidade do Estado da Bahia \\
\hline CFE & Conselho Federal de Educação \\
\hline TCC & Trabalho de Conclusão de Curso \\
\hline LDBEN & Lei de Diretrizes e Bases da Educação Nacional \\
\hline CAPES & Coordenadoria de Aperfeiçoamento de Pessoal de Nível Superior \\
\hline EsFEEx & Escola de Educação Física do Exército \\
\hline ENEFD & Escola Nacional de Educação Física e Desportos \\
\hline DEF & Divisão de Educação Física \\
\hline MEC & Ministério da Educação \\
\hline SESC & Serviço Social do Comércio \\
\hline SESI & Serviço Social da Insdústria \\
\hline UNE & União Nacional dos Estudantes \\
\hline USP & Universidade de São Paulo \\
\hline PT & Partido dos Trabalhadores \\
\hline CEEOESP & Congresso Estadual do Ensino Oficial do Estado de São Paulo \\
\hline FBAPEF & Federação Brasileira das Associações dos Professores de Educação Física \\
\hline APEF & Associação dos Professores de Educação Física \\
\hline IES & Intituição de Ensino Superior \\
\hline ISEF & Instituição Superior de Educação Física \\
\hline COESP & Comissão de Especialistas \\
\hline FHC & Fernando Henrique Cardoso \\
\hline $\mathrm{BM}$ & Banco Mundial \\
\hline UAB & Universidade Aberta do Brasil \\
\hline
\end{tabular}




\begin{tabular}{|c|c|}
\hline PROUNI & Programa Universidade para Todos \\
\hline FIES & Fundo de Financiamento Estudantil \\
\hline UNESCO & United Nations Educational, Scientific and Cultural Organization \\
\hline UFPE & Universidade Federal de Pernambuco \\
\hline UFSM & Universidade Federal de Santa Maria \\
\hline CBCE & Colégio Brasileiro de Ciências do Esporte \\
\hline UFRGS & Universidade Federal do Rio Grande do Sul \\
\hline RBCE & Revista Brasileira de Ciências do Esporte \\
\hline UFG & Universidade Federal de Goiás \\
\hline GTT & Grupo de Trabalho Temático \\
\hline NUTESES & Núcleo Brasileiro de Dissertações e Teses \\
\hline UFU & Universidade Federal de Uberlândia \\
\hline UFSC & Universidade Federal de Santa Catarina \\
\hline PUC & Pontifícia Universidade Católica \\
\hline FEF & Faculdade de Educação Física \\
\hline UNICAMP & Universidade Estadual de Campinas \\
\hline UNESP & Universidade Estadual de São Paulo \\
\hline UFMA & Universidade Federal do Maranhão \\
\hline FMI & Fundo Monetário Internacional \\
\hline SBPC & Sociedade Brasileira para o Progresso da Ciência \\
\hline SESU & Secretaria de Educação Superior \\
\hline CEE & Conselho Estadual de Educação \\
\hline SNDEL & Secretaria Nacional de Desenvolvimento de Esporte e de Lazer \\
\hline MEEF & Movimento Estuantil da Educação Física \\
\hline LEPEL & Linha de Estudos e Pesquisas em Educação Física, Esporte e Lazer \\
\hline \multirow[t]{2}{*}{ CONDIESEF } & Conselho de Dirigentes das Instituições de Ensino Superior de Educação \\
\hline & Física \\
\hline EXEENEF & Executiva Nacional dos Estudantes de Educação Física \\
\hline UFES & Universidade Federal do Espírito Santo \\
\hline
\end{tabular}


DEDC

IBGE

IDH

PNUD

PIB

FAEG

CONSEPE

CONSU

PARFOR

PROESP

PIEF

PPP

ENADE

SEED
Departamento de Educação

Instituto Brasileiro de Geografia e Estatística

Indice de Desenvolvimento Humano

Programa das Nações Unidas para o Desenvolvimento

Produto Interno Bruto

Faculdade de Educação de Guanambi

Conselho Superior de Ensino, Pesquisa e Extensão

Conselho Universitário

Plano Nacional de Formação de Professores

Programa de formação de Professores do Estado

Produção do Conhecimento e Intervenção Pedagógica

Pesquisa e Prática Pedagógica

Exame Nacional de Desenvolvimento de Estudantes

Secretaria de Educação Física e Desportos 


\section{SUMÁRIO}

INTRODUÇÃO 15

\section{CAPÍTULO 1 - O CONTEXTO HISTÓRICO DA FORMAÇÃO PROFISSIONAL EM EDUCAÇÃO FÍSICA

1.1 - As origens da formação em Educação Física 31

1.2 - Educação Física, Estado Novo e o primeiro modelo de formação profissional: a Educação Física como artífice da segurança nacional......................................................... 34 1.3 - Educação Física e democracia "populista": desdobramentos sobre a prática curricular. 39

1.4 - A Ditadura Militar e o segundo modelo curricular de formação profissional em Educação Física.

1.5 - Reabertura política e a nova proposta de formação curricular: o adeus ao currículo mínimo

\section{CAPÍTULO 2 - O DEBATE ACADÊMICO-CIENTÍFICO SOBRE AS DIRETRIZES CURRICULARES DE FORMAÇÃO EM EDUCAÇÃO FÍSICA A PARTIR DA

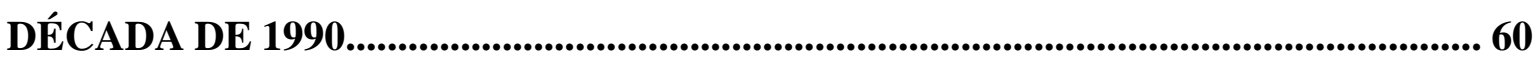

2.1 - Crise do capitalismo, neoliberalismo e as reformas na Educação Superior no Brasil 62

2.2 - Os impactos da crise capitalista atual na Educação Superior 66

2.3 - Neoliberalismo e a Reforma da Educação Superior. 68

2.4 - As reformas curriculares dos cursos de graduação. 70

2.5- O debate sobre a formação profissional em Educação Física que antecede a criação das novas Diretrizes Curriculares.

2.6 - Reflexões nada "aleatórias" sobre o processo de constituição histórica das Diretrizes Curriculares da Educação Física.

2.7 - Diretrizes Curriculares da Educação Física: reconhecendo limites, identificando possibilidades. 
CAPÍTULO 3 - EDUCAÇÃO FÍSICA E HIBRIDISMO CURRICULAR: O CASO DA

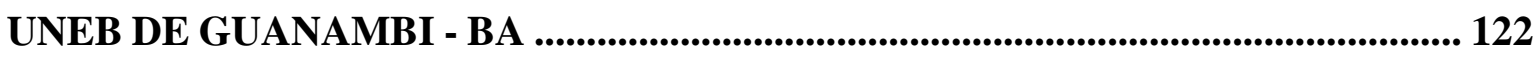

3.1 - Delineando o espaço da pesquisa.......................................................................... 123

3.1.1 - Caracterizando o estudo empírico............................................................. 125

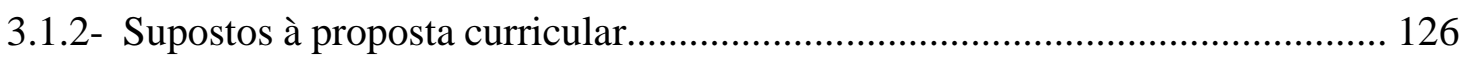

3.2 - O Projeto Curricular do Curso de Educação Física da Uneb - Campus XII -

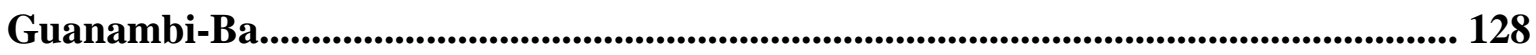

3.4.1 - Justificativa Curricular................................................................................... 130

3.4.2 - Concepções, Finalidades e Objetivos do Curso.............................................. 135

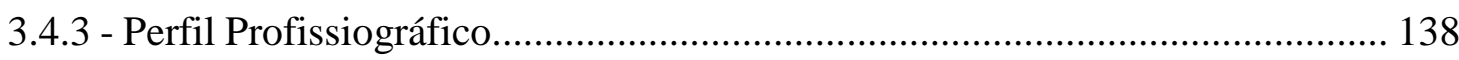

3.4.4 - Habilidades e Competências........................................................................ 139

3.4.5 - Estrutura Curricular e Abordagem Metológica.............................................. 140

3.4.6 - Formas de Avaliação..................................................................................... 148

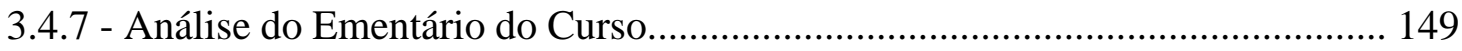

3.4.8 - Análise do Referencial Bibliográfico.......................................................... 151

3.3 - A Produção do Conhecimento no Curso de Educação Física da Uneb - Campus XII: evidenciando a divisão da formação profissional...................................................... 151

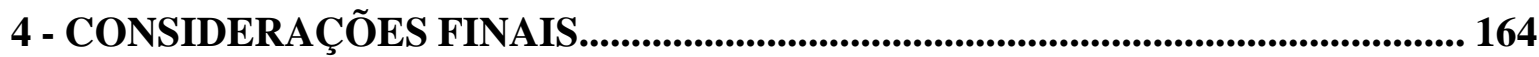

5 - REFERÊNCIAS BIBLIOGRÁFICAS.......................................................................... 173

6- ANEXOS 


\section{INTRODUÇÃO}

Nos últimos dez anos a formação profissional em Educação Física tem sido objeto de discussões acaloradas. $\mathrm{O}$ embate se dá fundamentalmente pelas repercussões das Diretrizes Curriculares da Educação Física, as Resoluções CNE/CP 01 e 02/2002 que fixam orientações não só para a formação em Licenciatura Plena em Educação Física, como também para todas as outras licenciaturas existentes em nosso país e a Resolução CNE/CES nº 07/2004 que trata do conhecimento identificador da área servindo, portanto, como complemento à diretriz de licenciatura, além de fixar orientações para a graduação/bacharelado em Educação Física.

Observando os trabalhos acadêmicos produzidos sobre formação profissional após a publicação dos referidos documentos, é possível identificar uma grande polêmica movida por parte de setores críticos da Educação Física associados ao Movimento Estudantil acusando as novas diretrizes curriculares de gerar o empobrecimento da formação profissional, além de contribuir para a redução do campo de atuação profissional da categoria. Ademais, atribuem protagonismo ao sistema CONFEF/CREF pela divisão da formação em Licenciatura e Graduação/Bacharelado.

Em outra perspectiva, existem análises também no campo progressista de que a divisão da formação em Educação Física não decorreu do protagonismo do CONFEF e por mais que possa se configurar como uma manobra neoliberal inspirada na crise do capitalismo do fim do século XX no Brasil, o contraditório nela presente pode ser explorado no sentido de qualificar a licenciatura no âmbito da educação escolar. Além disso, para esses pesquisadores, a formação em Educação Física apresenta problemas históricos que ainda não foram superados. O que parece existir é uma análise e interpretação do ordenamento legal da Educação Física a partir de postulados ideopolíticos que acabam impedindo uma mediação com a totalidade do problema. A análise fatorialista, levando em consideração apenas as determinações econômicas sobre o objeto estudado, acaba, contraditoriamente, estreitando a análise. Buscando estabelecer mediações com o método de conhecimento em Marx, José Paulo Netto (2011) nos revela essa mesma preocupação.

Assim, o conhecimento da realidade não demandaria os sempre árduos esforços investigativos, substituídos pela simples "aplicação" do método de Marx, que haveria de "solucionar" todos os problemas: uma análise "econômica" da sociedade forneceria a "explicação" do sistema político, das formas culturais, etc" ( p. 13). 
Podemos ainda arrematar que é o "ponto de vista da totalidade e não a predominância das causas econômicas na explicação da história que distingue de forma decisiva o marxismo da ciência burguesa" (LUKÁCS, 1974, p. 14).

Talvez essa fórmula mágica empregada por grande parte dos pesquisadores ao analisarem as Diretrizes Curriculares justifique a escassez de trabalhos que se proponham a avaliar concretamente as repercussões das orientações curriculares sobre a prática formativa dos profissionais da Educação Física. Vemos muitas profecias, entretanto, não é possível afirmar que elas estejam acontecendo pela ausência de dados empíricos que comprovem isso.

É a partir desse quadro saturado de contradições e antagonismos que extraio minha problemática, qual seja analisar as repercussões das Diretrizes Curriculares sobre a formação em Educação Física, um debate rico e ainda muito distante do seu término. A escolha desse problema de pesquisa justifica-se pela necessidade de ampliação dos estudos sobre a formação profissional em Educação Física a partir das novas diretrizes curriculares deslocando o olhar sobretudo para os currículos em vigor nos espaços formativos.

Em nosso entendimento, as pesquisas atualmente realizadas têm sido feitas muito mais com o foco nas possíveis determinações das orientações curriculares do que no processo de formação profissional. Compreendemos que as análises relacionadas com as determinações da economia política sobre o ordenamento jurídico da formação em Educação Física é apenas uma parte do problema, sendo necessário estabelecer mediações com a realidade concreta desse importante processo.

Tais relações nunca são diretas; elas são mediadas não apenas pelos distintos níveis de complexidade, mas, sobretudo, pela estrutura peculiar de cada totalidade. Sem o sistema de mediações (internas e externas) que articulam tais totalidades, a totalidade concreta que é a sociedade burguesa seria uma totalidade indiferenciada - e a indiferenciação cancelaria o caráter concreto, já determinado como "unidade do diverso". (NETTO, 2011, p. 57-58)

Em outra perspectiva, a análise precisa se debruçar no processo formativo, ou seja, como isso acontece no real concreto identificando novas categorias explicativas a fim de apreendermos a sua verdadeira essência.

Quando analisamos as diretrizes curriculares, que embora seja resultado do conjunto de intenções/aspirações de determinados grupos e, portanto, emana orientações normativas e 
curriculares a serem seguidas. Entretanto, devemos compreender seus limites em termos de abrangência e determinação.

Nesse sentido, a atribuição excessiva de importância às diretrizes como instrumentos capazes de determinar unilateralmente a formação, acaba por desprezar todas as outras determinações que incidem sobre o objeto aqui pensado, formação profissional em Educação Física. E para comprovar isso, podemos citar farto número de variáveis que têm significativa influência sobre a formação, como a qualificação dos professores, o currículo prescrito e vivido, que não são exatamente as diretrizes curriculares. A infraestrutura dos cursos acaba passando despercebida, isto porque, a análise corrente na ambiência acadêmica tem se detido apenas ao documento diretrizes curriculares, como se o processo de formação derivasse apenas e tão somente dele.

A partir dessas argumentações, é possível apontar inúmeras hipóteses associadas à problemática. A primeira delas é que, embora as diretrizes curriculares tenham sido construídas num momento histórico perpassado pela crise do capitalismo tardio e, dessa forma, associados por grande monta de pesquisadores ao projeto neoliberal, não necessariamente se consubstanciam como um documento exclusivamente a serviço dessa lógica. O que parece ter existido, e pretendemos ao longo do trabalho identificar, é que as diretrizes curriculares da Educação Física foram construídas a partir do embate entre grupos divergentes, e como tal, se revelando um documento contraditório.

Outra hipótese é que existem possibilidades concretas a partir do novo ordenamento legal de se estruturar projetos que contribuam para uma formação mais consistente, aprofundada e contextualizada tanto na licenciatura voltada para a atuação docente na Educação Básica, quanto na graduação/bacharelado. Ademais, apresentamos sumariamente outras hipóteses que analisaremos no curso desse estudo, além de se consubstanciarem em vetores reflexivos por parte de pesquisadores e dos professores envolvidos na formação em Educação Física.

1) Que a formação em Educação Física cumpriu a função de legitimação do modelo de sociedade idealizado pelos governos ditatoriais ao longo do século XX, com forte viés higienista, esportivista e moralista/patriótico;

2) Que setores conservadores da Educação Física já anunciavam na década de 80 a possibilidade da criação do bacharelado, porém, voltado para a formação do pesquisador, sobretudo nas grandes Universidades; 
3) Que licenciatura ampliada ou unificada não é o mesmo que formação ampliada. A primeira se refere aos campos de intervenção profissional, ou seja, a atuação profissional e a segunda à densidade, aprofundamento e consistência do processo de formação profissional;

4) Que é falacioso o embate sobre o divórcio entre a diretriz de graduação/bacharelado e a diretriz da licenciatura. $\mathrm{Na}$ verdade elas se complementam mais do que promovem a divisão da formação em Educação Física.

5) Que embora as diretrizes curriculares sejam de inspiração neoliberal, devemos reconhecer que, frente ao debate histórico sobre a formação profissional, representa não só limites, mas também possibilidades a partir de uma perspectiva dialógica, reflexiva, integrada e flexível de currículo;

6) Que parte das análises do processo de construção histórica das diretrizes apresenta contradições e um profundo maniqueísmo, em que determinados grupos se colocam na condição de defensores dos direitos dos trabalhadores enquanto situam outros atores reconhecidamente à esquerda, como traidores do projeto histórico de uma sociedade mais justa e fraterna;

7) Que a discussão sobre currículo e formação profissional tem apresentado maior ênfase em relação aos aspectos ideopolíticos do que sobre as questões que se referem ao currículo de formação;

8) Que o currículo escrito nem sempre determina o tipo de formação que sofrerá o aluno, uma vez que existem outras variáveis intervinientes no percurso formativo;

9) Que as diretrizes curriculares, a depender do contexto, são apropriadas e materializadas de formas diferenciadas nos projetos curriculares dos cursos;

10) Que podem existir tanto aproximações como distanciamentos nos projetos curriculares de cursos de Educação Física em relação às atuais diretrizes curriculares;

11) Que ao estabelecer integralidade e terminalidade próprias às licenciaturas, a Resolução 01/02 contribui para romper com o antigo modelo dual conhecido como $3+1$, abrindo espaço para o fortalecimento da base de formação do professor;

12) Que houve por meio da participação de diversos coletivos da Educação Física, avanços no processo de construção da Resolução CNE/CES nº 07/04, sobretudo, do parecer CNE/CP n ${ }^{\circ}$ 138/02 para o parecer CNE/CES 058/04, subsidiador da resolução em pauta;

13) Que não existem estudos empíricos em quantidade e qualidade que demonstrem os resultados do ponto de vista da formação profissional desse novo modelo curricular a partir das Resoluções CNE/CP n 01 e 02/2002 e CNE/CES nº 07/2004; 
14) Que a divisão na formação profissional em Educação Física se dá por dentro do próprio currículo de formação, consubstanciados por práticas de conhecimento e convívio ligados ao campo da saúde em detrimento das áreas sociais e pedagógicas.

Considerando esse enfoque, estruturaremos a nossa caminhada tendo em vista os seguintes objetivos:

\section{Objetivo Geral}

Analisar as repercussões das diretrizes curriculares (Resoluções CNE/CP n 01 e 02/2002 e Resolução CNE/CES nº 07/2004) sobre formação profissional em Educação Física, em especial, no curso da UNEB de Guanambi.

\section{Objetivos Específicos}

- Discutir o processo de constituição e evolução histórica dos currículos de formação profissional em Educação Física no Brasil tendo em vista as orientações e normativas legais;

- Refletir sobre a formação profissional a partir de artigos, teses, dissertações e capítulos de livros relacionados com os modelos curriculares orientados pelas Resoluções CFE $n^{\circ}$ 03/87, CNE/CP 01 e 02/2002 e CNE/CES 07/2004;

- Avaliar o ordenamento legal e o debate sobre a formação profissional, a estrutura e organização curricular do Curso de Educação Física da UNEB de Guanambi;

- Analisar criticamente a produção de conhecimento do Curso de Educação Física da Uneb de Guanambi a partir dos trabalhos de conclusão de curso - TCC.

\section{O caminho percorrido}

O objeto enquanto expressão fenomênica se apresenta com uma aparência imediata que nem sempre representa a sua verdadeira essência. O sujeito, a princípio, capta o objeto em sua imediaticidade ou em sua aparência. Essa apropriação sincrética do objeto revela o primeiro esforço de abstração sobre a realidade. O objeto a ser investigado possui uma característica 
própria, uma existência material própria independente do sujeito. O processo de compreensão da realidade e, portanto, do objeto, passa pela capacidade do sujeito identificar, o mais próximo do real, as propriedades que revelam a essência do objeto. Esse movimento é feito por meio de sucessivas aproximações sobre o objeto a fim de captar as suas determinações.

Nesse sentido, existe uma ontogênese no processo de conhecimento da realidade que nos permite desnudá-la e apreendê-la tomando como referência o movimento real, a coisa concreta. Assim, para analisar um determinado fenômeno, é preciso partir da sua concreticidade. Torna-se necessário estudar o objeto identificando sua natureza constitutiva, sua gênese, suas expressões imediatas, suas determinações, etc. Portanto, não podemos partir apenas da lógica formal para compreender o objeto, ou seja, a superestrutura, a economia, o modo de produção para compreendermos um determinado fenômeno da realidade. Nessa perspectiva,

O conhecimento teórico é o conhecimento do objeto - de sua estrutura e dinâmica - tal como ele é em si mesmo, na sua existência real e efetiva, independente dos desejos, das aspirações e das representações do pesquisador. A teoria é para Marx, a reprodução ideal do movimento real do objeto pelo sujeito que pesquisa: pela teoria, o sujeito reproduz em seu pensamento a estrutura e a dinâmica do objeto que pesquisa. E esta reprodução (que constitui propriamente o conhecimento teórico) será tanto mais correta e verdadeira quanto mais fiel o sujeito for ao objeto. (NETTO, 2011, p. 20-21)

Desta forma, o verdadeiro ofício e intento do pesquisador é reunir estratégias que permitam aproximá-lo ao máximo da essência do objeto tentando reproduzir idealmente o seu movimento real. Assim, tendo em vista o nosso objeto principal que é identificar as repercussões das diretrizes curriculares sobre a formação profissional, procuraremos, inicialmente, entrar em contato com os discursos produzidos pelos estudiosos da Educação Física a respeito da formação profissional em Educação Física objetivando captar as suas impressões sobre a maneira pela qual esse processo se deu e foi evoluindo em nosso país. Importa, também, identificar ao longo desse percurso os avanços e retrocessos em relação ao processo de formação desses profissionais. Esse estudo terá como categoria fundante a totalidade, ao analisar e considerar a formação profissional em Educação Física como um complexo envolvido por um complexo maior que lhe impõe determinações.

Para Marx, a sociedade burguesa é uma totalidade concreta. Não é um todo constituído de partes funcionalmente integradas. Antes, é uma totalidade 
concreta inclusiva e macroscópica, de máxima complexidade, constituída por totalidades de menor complexidade. (NETTO, 2011, p. 56)

Assim, poderemos perceber que o nosso objeto se modifica a partir das determinações da economia, da política, mas, também da cultura, da correlação de forças que geram relações de poder tanto verticalmente como horizontalmente. Dessa forma, foi possível identificar variadas contradições em nosso objeto de estudo que relataremos na continuidade desse estudo.

Em seguida à análise dos discursos legais e acadêmicos relacionados à formação profissional em Educação Física, optamos por nova frente de estudos voltada para o conhecimento do objeto nos espaços em que se materializa como fenômeno social e educacional. Para tanto, escolhemos o projeto do Curso de Educação Física da Universidade do Estado da Bahia - Campus XII em Guanambi-BA. O nosso intuito foi estabelecer mediações com o projeto pedagógico do curso a fim de identificarmos suas aproximações e distanciamentos em relação às Diretrizes Curriculares da Educação Física. Também foi relevante destacarmos as contradições presentes no currículo de formação, sobretudo no desvirtuamento das suas finalidades formativas, uma vez que se configura como um curso de Licenciatura que, embasado na Resolução CNE/CP 01 e 02/2002, deveria estar focalizando a formação do professor para atuar na Educação Básica. Ao contrário disso, parece se organizar e se estruturar para dar ênfase à formação de um profissional capaz de atuar tanto na escola como no mercado emergente da Educação Física, qual seja, as Academias, Clubes e outros espaços que desenvolvem atividades físicas, de lazer e esporte. É possível entendê-la como uma licenciatura ampliada na medida em que prioriza muito mais a abrangência da atuação profissional do que o aprofundamento em termos do domínio de conhecimento para essa atuação. As consequências desse modelo resultam na precarização e empobrecimento da formação do docente para atuar na Educação Básica.

Por fim, foi necessário para o estudo definir técnicas e selecionar instrumentos de coleta e análise dos dados que permitissem alcançar os objetivos da pesquisa. Neste processo, os instrumentos e também as técnicas de pesquisa são os mais variados, desde a análise documental até as formas mais diversas de observação, recolha de dados, quantificação, etc. Vale ressaltar que esses instrumentos são apenas meios que se vale o pesquisador para apoderarse da matéria, não devendo se confundir com o método, inclusive porque os mesmos podem ser utilizados em outros tipos de concepção metodológicas diferentes (NETTO, 2011). Assim, explicaremos a seguir a estratégia utilizada para esse estudo. 


\section{Pesquisa sobre o "estado da arte" da formação profissional em Educação Física}

Fizemos uma análise da produção acadêmico-científica sobre os trabalhos vinculados à formação de professores de Educação Física desenvolvidas no Brasil. Para tanto, tomamos como base uma pesquisa do "estado da arte" ou "estado do conhecimento", com a finalidade de mapear e discutir a produção acadêmica no âmbito da Educação Física.

Intentamos com isso realizar um balanço sobre o debate teórico na área de formação profissional num período compreendido entre 1990 a 2013. A opção por esse período se justifica por ter sido aquele onde se deram as principais reflexões do campo quanto à necessidade de reformulação dos currículos, período que coincide com o processo de reorientação das políticas sociais (via diretrizes dos organismos multilaterais e reforma de Estado) culminando com aprovação da Lei de Diretrizes e Bases da Educação Nacional (LDBEN no 9.394/96) e, também, da Reforma da Educação Superior, sobretudo com a aprovação das Resoluções CNE/CP nº 01 e 02/2002 e a Resolução CNE/CES nº 07/2004.

Nesse sentido, fizemos no período indicado acima, um estudo das publicações relacionadas à formação profissional em Educação Física, objetivando levantar, organizar e analisar a produção acadêmica publicada em periódicos da área da Educação Física pertencentes aos estratos A2, B1, B2, B3, B4 nos periódicos da Área 21 (Educação Física, Fisioterapia, Fonoaudiologia e Terapia Ocupacional) da Coordenadoria de Aperfeiçoamento de Pessoal de Nível Superior (CAPES), que veiculam sua produção científica em diálogo com as Ciências Humanas e Sociais.

Esse levantamento foi feito de acordo com os pressupostos apresentados por Saviani (1991), relacionados à produção de monografia de base. De acordo com esse autor, a monografia de base constitui um estudo detalhado de um tema específico e restrito que visa organizar as informações disponíveis sobre o assunto em estudo, de modo a servir de embasamento para o desenvolvimento de estudos futuros.

Dessa forma, procuramos identificar e sistematizar os estudos e pesquisas produzidos; reconhecer os principais resultados das investigações realizadas; identificar temáticas e abordagens dominantes ou emergentes, bem como lacunas e campos inexplorados abertos à pesquisa futura. 


\section{Pesquisa documental}

Segundo Gil (2007), a pesquisa documental vale-se de materiais que ainda não receberam um tratamento analítico ou que ainda podem ser reelaborados de acordo com os objetivos da pesquisa. Esse tipo de pesquisa apresenta-se vantajosa, pois os documentos constituem fonte rica e estável de dados, gera poucos custos, pois a análise dos documentos, em muitos casos, além da capacidade do pesquisador, exige apenas disponibilidade de tempo.

Nesse estudo, avaliamos documentos relacionados ao processo de elaboração, estruturação, organização e execução curricular do curso em pauta, dentre os quais: Lei n ${ }^{\circ} 9.394$ de 20 de dezembro de 1996, que estabelece as diretrizes e bases da educação nacional, bem como o Decreto n ${ }^{\circ}$ 6.755, de 29 de janeiro de 2009 que institui a Política Nacional de Formação de Profissionais do Magistério da Educação Básica; Resoluções CNE/CP 01 e 02/2002 (Diretrizes curriculares para a formação de professores); Resolução CNE/CES 07/2004 (Diretriz para a Graduação/Bacharelado em Educação Física); e os demais documentos referentes ao currículo de formação, entendido aqui como o percurso formativo do aluno. Entre eles estão: Estatutos, Regimentos, Projeto do Curso, Resoluções, Atos, Atas de reuniões, etc. Com essas fontes documentais tivemos a pretensão de analisar, interpretar a estrutura e a organização curricular do curso de Educação Física da UNEB de Guanambi.

Outra importante análise documental foi feita em relação aos Trabalhos de Conclusão de Curso - TCC que são produzidos pelos graduandos por ocasião da conclusão do Curso. Esses trabalhos são desenvolvidos desde o ano de 2003, entretanto, para efeito desse estudo, nos ocupamos apenas dos trabalhos produzidos após o processo de redimensionamento do currículo em 2004, derivando os primeiros trabalhos somente a partir do ano de 2008. Desta forma analisamos todos os trabalhos produzidos no intervalo entre 2008 a 2013, definindo categorias que melhor explicassem o tipo de conhecimento que vem sendo refletido/produzido e, a partir disso, o perfil de profissional e sua compreensão sobre a função social da Educação Física.

\section{Estrutura e organização do trabalho}

Para além desta introdução, este trabalho encontra-se organizado da seguinte forma:

Introdução - Esse primeiro tópico teve a intenção de servir como um "aperitivo" aos leitores da dissertação. Nele a problematização do tema pesquisado, enfocando as suas questões principais e o debate que tem sido feito pelos diversos setores da Educação Física. Ainda nesse 
tópico, apresentamos as finalidades do trabalho, hipóteses, bem como os caminhos a serem trilhados para tal fim.

Ao final, apresentou a estrutura dissertativa, ou seja, como o trabalho foi organizado em termos do número e nomes dos capítulos, além de descrever sucintamente o que foi tratado em cada um deles.

\section{Capítulo 1 - O contexto histórico da formação profissional em Educação Física -}

Neste capítulo, foi realizada uma incursão histórica a fim de resgatar elementos que contribuíram para a caracterização da formação profissional nesta área de atuação profissional. A intenção foi de identificar os aspectos por meios dos quais foram assentadas as bases para a construção dos modelos de formação profissional desta área de conhecimento; quais os objetivos da sua formação; qual o contexto histórico-social, econômico e político e suas repercussões sobre o processo de organização dos currículos. São questões necessárias de serem respondidas para melhor clarificar a evolução histórica da formação profissional na área em análise. Para tanto, organizamos o capítulo a partir de quatro recortes históricos: Educação Física, Estado Novo e o primeiro modelo de formação profissional: a Educação Física como artífice da segurança nacional; Educação Física e democracia "populista": desdobramentos sobre a prática curricular; o modelo curricular de 69 e a ditadura militar; e a Reabertura política e a nova proposta de formação curricular: o adeus ao currículo mínimo.

Por meio do subtópico "As origens da formação em Educação e em Educação Física" buscamos identificar os primeiros movimentos da sociedade em busca da construção de uma cultura formativa no âmbito da Educação Física.

Depois desse primeiro esforço para identificar a gênese da formação em Educação Física em nosso país, passamos a analisar mais detidamente os modelos curriculares de formação profissional. Com essa finalidade, tivemos como primeiro recorte de análise o subtópico "Educação Física, Estado Novo e o primeiro modelo de formação profissional: a Educação Física como artífice da segurança nacional”.

É precisamente nesse período que analisamos o surgimento do primeiro modelo curricular de formação em Educação Física com a publicação do Decreto-lei no 1.212 , que cria na Universidade do Brasil a Escola Nacional de Educação Física. Encontra-se também alinhavados neste Decreto-lei, as bases mais elaboradas daquele que poderíamos chamar de primeiro currículo - de nível superior - de formação de profissionais de Educação Física e Esporte no Brasil, evidentemente sincronizado com os objetivos estadonovistas anteriormente mencionados ( CASTELLANI FILHO, 1988). 
No subtópico Educação Física e democracia "populista": desdobramentos sobre a prática curricular, identificamos que, em relação à Educação Física, inaugurou-se um grande debate em torno da revisão de paradigmas na área, tendo como principal reivindicação o processo de desmilitarização da Educação Física Escolar.

No subtópico "o modelo curricular de 69 e a ditadura militar", observamos que a ambiência social em que se dá a aprovação do segundo currículo de formação profissional em Educação Física é bastante autoritária, repressiva e conflituosa. A sua regulamentação se dá por intermédio do Parecer 894/69 e da Resolução no 69, de 06 de dezembro de 1969, do Conselho Federal de Educação (CFE), tendo como principal aspecto a fixação do currículo mínimo dos Cursos de Educação Física.

Finalmente, no subtópico "Reabertura política e a nova proposta de formação curricular: o adeus ao currículo mínimo", vimos como a Educação Física nos anos 1980 inaugurou uma nova fase em que se busca encontrar a sua identidade histórico-social e seu sentido pedagógico. Essa terceira perspectiva curricular foi regulamentada por meio da Resolução CFE nº 03/87 em 16 de junho de 1987.

Capítulo 2 - $O$ debate acadêmico-científico sobre as Diretrizes Curriculares de formação em Educação Física a partir da Década de 1990 - Neste capítulo buscamos interpretar a discussão curricular em torno das novas diretrizes levando em conta o contexto mais geral da sociedade e seus processos históricos. Analisamos, também, a evolução das discussões sobre formação no campo da Educação Física.

Ao final, após as mediações feitas ao longo do capítulo, buscamos refletir sobre as atuais diretrizes curriculares da Educação Física enquanto marco legal, mas também contraditório e inacabado, reconhecendo os seus limites e identificando avanços e possibilidades no processo de formação profissional que não estejam restritos apenas ao currículo escrito, mas sobretudo ao currículo vivido, à experiência no processo de execução curricular e suas contradições históricas.

\section{Capítulo 3 - Educação Física e hibridismo curricular: o Curso da UNEB de} Guanambi - BA - Aqui nos importou analisar a experiência dos coletivos envolvidos na formação profissional da Educação Física, avaliando como esses atores sociais interpretaram as novas diretrizes curriculares e, a partir delas, construiram e executaram projetos curriculares e as alternativas pedagógicas vinculadas a formação dos novos professores. 
Além disso, nos preocupamos em analisar a produção do conhecimento sobre a Educação Física produzida pelos alunos em seus Trabalhos de Conclusão de Curso na tentativa de encontrar nexos e contradições com o que prevê as normas atuais e o projeto do Curso.

Considerações finais - Nesse capítulo, respaldado pelas análises consubstanciadas nas pesquisas bibliográficas e documentais, coube a nós apresentar as conclusões/sugestões sobre o assunto. 


\section{CAPÍTULO 1 - O CONTEXTO HISTÓRICO DA FORMAÇÃO PROFISSIONAL EM EDUCAÇÃO FÍSICA}

Os estudos históricos relacionados com a Educação Física remontam a 1916 e 1920 quando é publicado o "Da Educação Physica” de Fernando de Azevedo. Na década de 40, Inezil Pena Marinho dá continuidade à esses estudos a partir de uma abordagem cronológica e linear da história. Somente a partir dos anos 1980, com a redemocratização da sociedade brasileira, é que autores como Castellani Filho, Vitor Marinho, Paulo Ghiraldelli Júnior e outros apresentam as primeiras leituras críticas sobre esta temática.

Nesse trabalho analisamos a formação profissional na área da Educação Física, em particular as relações entre as atuais Diretrizes Curriculares de formação e a prática curricular ou prática formativa no âmbito das Instituições de Ensino, especialmente o Curso de Educação Física da UNEB - Campus XII no município de Guanambi. Os princípios teóricometodológicos que norteiam a nossa pesquisa apontam para a análise do objeto tendo como referência o materialismo histórico-dialético sendo, portanto, necessário o uso de categorias marxianas como a totalidade, particularidade, mediação, contradição entre outras categorias identificadas no processo de estudo. Nesse sentido, a identificação e a reflexão crítica sobre as determinações sociais, econômicas, políticas e culturais que incidem sobre o objeto serão, em conjunto, fundamentais para captarmos a sua essência.

Além do princípio da totalidade, devemos estar atentos à outras categorias e variáveis capazes de determinar o objeto, ou seja, além das suas determinações gerais e globais, notadamente às que se referem à política e à economia, se faz necessário avaliarmos outros determinantes presentes no processo de formação na ambiência formativa.

Baseado nessas premissas teórico-metodológicas, iniciaremos o nosso estudo tentando compreender o contexto geral, o pano de fundo em que se dá o percurso da formação profissional, exibindo as contradições no seu processo de evolução, resultante das tensões entre capital e trabalho.

Como categoria básica do nosso trabalho, é importante refletirmos sobre o significado de formação profissional. A princípio a expressão nos remete a compreendê-la enquanto processo, ou seja, um processo de formação de um profissional. O termo profissional deriva de profissão, ou seja, de alguém que realiza algum trabalho específico. Para Schon (1992) apud Sherer (p. 36, 2005), 
profissional é alguém que recorre ao conhecimento extraordinário em assuntos de grande importância humana. Ao profissional outorga-se um mandato especial para o controle social em assuntos próprios de sua perícia, uma licença para determinar quem fará parte de seu campo profissional e quem terá um relativo grau elevado de autonomia na regulamentação de sua prática.

Marques (2000) citado por Sherer (2005, p. ), diz que “ a profissão não é apenas uma atividade ocupacional, mas um compromisso social que é inserido na política da sociedade de maneira diferenciada e que exige qualificação técnico-científica específica para campos de atuação."

Desta forma, podemos inferir que um profissional deverá estar sempre munido de conhecimentos instrumentais e científicos que o habilitarão a atuar profissionalmente. Além disso, deverá possuir uma conduta ética e um compromisso social que moverão o seu trabalho com vistas a atender as aspirações de uma determinada sociedade num determinado contexto social e histórico.

A formação do profissional deverá adquirir então contornos no campo teórico e metodológico que possibilitem a formação de um profissional realmente preparado para atuar em seu contexto societário de modo que atenda as demandas sociais. É verdade que na atualidade e no contexto societário dominante, o que vemos é a formação profissional para atender aos ditames do capital ou à maximização dos lucros daqueles que controlam os meios de produção.

Visando compreender o processo de formação profissional, em especial na Educação Física, faremos, a partir de agora, uma incursão histórica a fim de resgatar elementos que contribuíram para a caracterização do profissional da Educação Física. Sobre quais aspectos foram gestados os modelos de formação profissional na área da Educação Física? Quais os objetivos dessa formação? Qual o contexto histórico-social, econômico e político e, a partir dele, quais tensões se deram sobre a organização dos currículos de formação profissional em Educação Física? São questões a serem respondidas para que tenhamos uma noção mais clara em torno da evolução histórica da formação profissional na área em análise. 


\section{1 - As origens da formação em Educação Física}

A primeira metade do século XX no Brasil é marcada por radicais transformações sociais, políticas e econômicas que conferem definitivamente ao Brasil o título de país capitalista. Para Castellani Filho,

Constituíram, a nosso ver, os anos 1930, uma importante etapa na definição dos rumos do capitalismo industrial no país, no lançamento das bases de um novo modelo; pressupostos necessários à que esse modelo viesse a se desenvolver plenamente na década de 1950. Marcado por um intenso processo de modernização e por reformas políticas bastante significativas operou-se no país, naqueles anos, a transição de uma sociedade agroexportadora para uma sociedade de base urbano-industrial; processo de transição esse que definia a passagem de uma ordem social essencialmente rural para uma ordem urbana, na qual o setor industrial passaria a ser o elemento dinâmico da economia (1988, p.63-64).

A transição do modelo agroexportador para o urbano-industrial provocaria desdobramentos sociais significativos. A economia capitalista impõe à sociedade novos conceitos, novas necessidades de consumo e, contraditoriamente, a intensificação da miséria, assim descrita por Soares,

Uma economia urbano-comercial é desenhada, uma elite com ideias burguesas, europeias se projeta, a miséria e a prostituição crescem nas cidades, as doenças e as epidemias de mãos dadas com a morte, são o cartão de visitas dos portos... O capitalismo está nascendo no Brasil (1994, p.108).

Nesse capitalismo de características hostis e peculiares a um país colonizado por Portugal, nação que não conseguiu o mesmo grau de desenvolvimento dos outros países Europeus, expõe uma realidade difícil no que se refere à expansão e qualificação desse sistema em terras brasileiras. Cresce, com isso, os esforços da intelectualidade burguesa no sentido de pensar políticas públicas que pudessem assegurar o pleno desenvolvimento dessa economia. Rui Barbosa talvez tenha sido o principal protagonista desse processo. Para ele, a chave que abriria as portas para o desenvolvimento brasileiro seria a educação. Combatia a ignorância de forma veemente em seus discursos como sendo “... a mãe da servilidade e da miséria, (como) a grande ameaça contra a existência constitucional e livre da nação; (como) o formidável inimigo intestino que se asila nas entranhas do país.” Barbosa apud Soares, (p. 107, 1994).

Mas, além da educação, Rui Barbosa defendeu também a necessidade da saúde, afinal, num país pretenso a potência capitalista, seria inconcebível permanecer nas condições de saúde 
em que se encontrava. Para tanto, defendeu a higiene a ser disseminada por meio da educação no interior das escolas a partir de práticas já estruturadas nos países capitalistas centrais (SOARES, 1994).

Como artífices dessa política, estariam os médicos, profissionais identificados com os preceitos científicos, produzindo ações como a difusão de conhecimentos voltados para a higiene, vacinações em massa e, especialmente, os cuidados com o corpo no processo educacional dos jovens.

É dever primário da existência humana "cuidar do corpo", "da saúde", e a ginástica seria o elemento capaz de promover a saúde através do "saudável" exercitar dos músculos, atividade esta que deveria tornar-se hábito. (...) Uma educação popular que não contemplasse a ginástica seria considerada indigna desse nome, porque a ginástica deveria acompanhar todo o ensino e plantar no homem o sentimento de usa necessidade, assim como "... do pudor, da urbanidade e do asseio.” (BARBOSA apud SOARES, p.111, 1994)

Os cuidados com o corpo acima referenciados deveriam se materializar por meio do desenvolvimento muscular, da atitude e disciplina dos jovens. Esses atributos físicos e morais deveriam ser desenvolvidos pela ginástica. No século XIX na Europa, a partir dos estudos de professores como Guts Muts, Friederich Ludwig Jahn e Adolph Spiess na Alemanha, Pehr Henrick Ling na Suécia, D. Francisco de Amorós, George Demeny, Philipe Tissié, Fernand Lagrange e Esteban Marey na França fundam, respectivamente os métodos Alemão, Sueco e Francês ${ }^{1}$.

A racionalidade científica, pilar para o desenvolvimento social, seria aqui empregada e defendida no Brasil a partir dos discursos da intelectualidade brasileira, em especial os de Rui Barbosa ao observar que

... a ginástica, além de ser o regimen fundamental para a reconstituição de um povo cuja virilidade se depaupera e desaparece de dia em dia a olhos vistos, é ao mesmo tempo, um exercício eminentemente, insuperavelmente moralizador, um germem de ordem e um vigoroso alimento da liberdade. Dando a criança uma presença erecta e varonil, passo firme e regular, precisão e rapidez de movimentos, prontidão no obedecer, asseio no vestuário e no corpo, assentamos insensivelmente a base de hábitos morais, relacionados pelo modo mais íntimo com o conforto pessoal e a felicidade da futura família, damos lições práticas de moral, talvez mais poderosas do que os preceitos inculcados verbalmente. (BARBOSA apud SOARES, p. 112, 1994)

\footnotetext{
${ }^{1}$ Métodos ginásticos desenvolvidos no século XIX na Europa com o objetivo de desenvolver a aptidão física, a disciplina, higiene e a moral como forma de atender as demandas do trabalho e da guerra, além de outras finalidades.
} 
Portanto, a ginástica aqui defendida, para além do desenvolvimento muscular harmonioso, da postura, etc, estaria atrelada também ao cultivo da disciplina, da moral e da ordem imprescindíveis à sustentação e legitimação da nova sociedade.

Os métodos ginásticos foram desenvolvidos inicialmente com finalidades militares e só depois adaptados para a população de um modo geral. Portanto, não havia escolas de formação de professores de ginástica, sobretudo no Brasil do início do século XX. Os primeiros esforços de difusão dos métodos e, consequentemente de formação de instrutores de ginástica se deram na ambiência militar. Foi comum nesse período a visita de missões militares da Europa para instruir os militares brasileiros em relação aos métodos ginásticos. Inicialmente, atuavam na caserna sendo requisitados a posteriori para atuarem nas escolas.

Os métodos também foram sendo adaptados para civis e, nesse intento, dando maior ênfase ao que se convencionou chamar pelos estudiosos da área como ginástica pedagógica que concentrava seus objetivos na postura, na definição das formas e na reabilitação do corpo de seus participantes.

A formação em Educação Física no Brasil originou-se nas Escolas da Marinha e Militar. Inicialmente, o método alemão era o mais utilizado nos estabelecimentos militares, até ser substituído pelo método francês em 27 de abril de 1921. Nas escolas, os métodos mais aceitos e utilizados no Brasil foram o Francês e o Sueco.

Por meio do decreto $\mathrm{n}^{\circ}$ 23.252, em 19 de outubro de 1933, o Governo Vargas criou a Escola de Educação Física do Exército- EsEFEx no Rio de Janeiro formando além de oficiais e sargentos, também civis como monitores. Em maio de 1936, foi criada a Escola da Educação Física da Força Pública de São Paulo por meio do decreto n ${ }^{\circ}$ 7.688. Vale ressaltar que esse foi o primeiro programa civil de um curso de educação física de que se tem notícia, mas, que só começou a funcionar em 1943. É possível identificar durante a década de 1930, outras inciativas em relação à formação profissional em estados como o Espírito Santo, Pará, Pernambuco, São Paulo, porém, sem regulamentação oficial e pautado no modelo dos cursos militares que, por sua vez, utilizavam o chamado método francês para o ensino das atividades ministradas (SOUZA NETO et ali, 2004).

Além desses cursos, houve também a criação em 1938, de um curso de emergência, promovido pelo Departamento de Educação Física e orientado didaticamente pela EsEFEx. Esse curso de emergência foi criado para formar instrutores de educação física da sociedade civil, mas, parte do corpo docente da ENEFD foi formado por pessoas que o concluíram. Assim, 
pressupõe-se que o referido curso tenha também tido como objetivo a formação de profissionais para atuar na docência da ENEFD (MALINA e AZEVEDO, 1998).

Desta forma, podemos analisar que o cenário social, político e econômico da época exigia medidas urgentes no sentido de promover a formação de professores de Educação Física que pudessem estender o seu conhecimento, sob bases biológicas, difundindo a prática da ginástica nas escolas em nome da disciplina, higiene e saúde da população brasileira. O conjunto desses esforços resultará pela primeira vez na Constituição de 1937, da obrigatoriedade da Educação Física nas escolas, fazendo surgir outras reivindicações, como, por exemplo, a exigência de um currículo mínimo para a graduação.

\section{2 - Educação Física, Estado Novo e o primeiro modelo de formação profissional: a Educação Física como artífice da segurança nacional}

Para analisarmos o primeiro modelo de formação profissional em Educação Física é fundamental que compreendamos os seus nexos com o modelo político-social vigente neste período. O Brasil entrava em contato com o seu primeiro regime ditatorial, nomeado como Estado Novo. Protagonizado pelo presidente Getúlio Vargas, conhecido, também, como o pai dos pobres em virtude da sua face populista ${ }^{2}$, mas, também, pelos avanços em relação aos direitos trabalhistas ${ }^{3}$, caracterizava-se como um regime antidemocrático e de exceção, mas, com forte viés desenvolvimentista. Vargas, simpatizante do nazi-fascismo ${ }^{4}$, acreditava na força da coerção e da manipulação da população para conduzir a nação rumo ao desenvolvimento. Ideais de patriotismo e civismo aliado à prática de exercícios físicos como forma de preparação para o trabalho e para a guerra eram algumas das frentes de ação político-governamental priorizadas por Getúlio.

A Educação Física tendo como suporte os métodos ginásticos e o esporte numa abordagem moralista e disciplinadora, se ajustaram perfeitamente aos ideais estadonovistas ${ }^{5}$. Restava, então, o desenvolvimento de políticas visando à formação de professores que pudessem executar eficientemente essas ações educativas. Para tanto, foram criados órgãos

\footnotetext{
${ }^{2}$ Estratégia política que visa criar e divulgar uma imagem positiva de uma determinada personalidade em detrimento de suas fragilidades.

${ }^{3}$ No governo Vargas foi criada a Consolidação das Leis Trabalhistas - CLT, que assegurava a garantia de direitos no campo trabalhista a todos os trabalhadores regidos por esse regime.

${ }^{4} \mathrm{O}$ nazi-fascismo foi uma doutrina política que surgiu e se desenvolveu, principalmente, na Itália e Alemanha entre o começo da década de 1920 até o final da Segunda Guerra Mundial.

${ }^{5}$ Os ideais estadonovistas referiam-se ao controle da população por meio do cultivo à ordem, patriotismo e nacionalismo e a repressão aos insurgentes.
} 
governamentais que tinha como missão estruturar a formação de professores de Educação Física com o perfil requisitado pelo regime ditatorial de Vargas. Um desses órgãos se chamava Divisão de Educação Física - DEF e foi criado em 1937 por meio da lei 378 de 13 de janeiro de 1937. Era ligado ao Ministério da Educação e da Saúde com funções ligadas à formação do professor de Educação Física. Um dos seus principais objetivos era fiscalizar a prática curricular da Educação Física no sistema educacional no país, em especial a do Método Francês, recémoficializado. Para se ter uma ideia da sua efetividade em relação a esse processo, o professor Cantarino Filho, em sua pesquisa, afirma que:

A rigorosa fiscalização empreendida pela DEF levou o Método Francês a ser, em pouco tempo, efetivamente adotado em todos os cursos secundários: em 1938, 61,6\% dos estabelecimentos de ensino secundários adotavam o Método Francês; em 1939, essa porcentagem subiu a $81,3 \%$; em 1940, a 90,6\% e, em 1941, sua adoção foi praticamente integral (1982:137). (...) Outros métodos de ginástica existentes, como o sueco e o alemão, rapidamente desapareceram de cena. Ao mesmo tempo, houve uma rápida profissionalização dos professores: em 1939 havia 50,8\% de leigos, em 1941 apenas 36,3\% $(1982: 160)$.

Além da fiscalização da execução curricular nos estabelecimentos de ensino, a DEF foi também responsável pela formação profissional na Educação Física, marcando, com isso, a presença militar em relação a esse processo em nosso país. Sobre esse prisma Melo acrescenta que,

Este órgão era o primeiro especializado no nível administrativo federal, sendo responsável por sistematizar e regulamentar todo o processo de formação profissional. Para funcionar os cursos primeiramente deveriam solicitar a autorização para tal e, somente depois do seu reconhecimento, estariam legitimados a iniciar as atividades, porém, seriam periodicamente inspecionados (MELO, 2007).

Contemplando os esforços da ESEFEx ${ }^{6}$ e da DEF, no dia 17 de Abril de 1939, foi criada a ENEFD - Escola Nacional de Educação Física e Desportos da Universidade do Brasil.

Ela será, antes do mais, um centro de preparação de todas as modalidades de técnicos ora reclamados pela educação física e pelos desportos. Funcionará, além disso, como um padrão para as demais escolas do país, e, finalmente, como um estabelecimento destinado a realizar pesquisa sobre o problema da

\footnotetext{
${ }^{6}$ Escola de Educação Física do Exército (EsEFEx), criada em 1932, para formar instrutores, monitores, mestre d'armas, médicos especializados. Os cursos eram destinados aos militares, mas muitos civis realizaram o curso de monitor.
} 
educação física e dos desportos e a fazer permanente divulgação dos conhecimentos relativos a tais assuntos. (MARINHO, 1952, p.51)

Portanto, a criação da ENEFD, representa um marco importante em relação à formação profissional em Educação Física porque, para além de ser uma escola de formação de professores, estaria se constituindo numa referência para as outras escolas. Precisamos ainda destacar que há uma vinculação clara entre os interesses políticos do estado e essa inciativa quando promove o adestramento físico do trabalhador, enquanto destinava às instituições patronais a responsabilidade pela formação técnica.

(...) o poder executivo, através do Decreto-lei $\mathrm{n}^{\circ} 1.212$, cria na Universidade do Brasil a Escola Nacional de Educação Física. Encontra-se também alinhavados neste Decreto-lei, as bases mais elaboradas daquele que poderíamos chamar de primeiro currículo - de nível superior - de formação de profissionais de Educação Física e Esporte no Brasil, evidentemente sincronizado com os objetivos estadonovistas anteriormente mencionados. (CASTELLANI FILHO, 1988, p. 22-23)

Do ponto de vista curricular os cursos eram estruturados por um núcleo de disciplinas básicas e um conjunto de matérias específicas em função da modalidade de atuação profissional pretendida. A diferença entre um técnico e o professor era que o segundo deveria possuir disciplinas pedagógicas que o identificasse como educador. Interessados em compreender melhor essa proposta, apresentamos no quadro abaixo alguns dados sobre os saberes e a habilitação profissional oriundas desse currículo.

\section{Quadro 1 - Currículo de formação em Educação Física(1939)}

\begin{tabular}{|c|c|}
\hline Saberes & \\
\hline $\begin{array}{l}\text { Estudo da vida humana em seus aspectos } \\
\text { celular, anatômico, funcional, mecânico, } \\
\text { preventivo }\end{array}$ & \multirow{7}{*}{$\begin{array}{l}\text { Instrutores de Ginástica (professoras } \\
\text { primárias) } \\
\text { Instrutor de Ginástica } \\
\text { Professor de Educação Física } \\
\text { Técnico em Massagem Técnico Desportivo }\end{array}$} \\
\hline $\begin{array}{l}\text { Estudo dos exercícios físicos da infância à } \\
\text { idade madura }\end{array}$ & \\
\hline $\begin{array}{l}\text { Estudo dos exercícios motores lúdicos e } \\
\text { agonísticos }\end{array}$ & \\
\hline Estudo dos exercícios motores artísticos & \\
\hline $\begin{array}{l}\text { Estudo do processo pedagógico (psicologia } \\
\text { aplicada) }\end{array}$ & \\
\hline $\begin{array}{l}\text { Estudo da administração do trabalho humano } \\
\text { em instituições (organização; legislação) }\end{array}$ & \\
\hline $\begin{array}{l}\text { Estudo dos fatos e costumes relacionados às } \\
\text { tradições dos povos na área dos exercícios } \\
\text { físicos e motores }\end{array}$ & \\
\hline
\end{tabular}

Fonte: Adaptado de (SOUZA NETO et ali, 2004) 
Com exceção do curso para formar professores que era de dois anos, os demais duravam apenas um ano. É importante registrar, também, que cerca de dois anos mais tarde passou-se a exigir o diploma de graduação para a atuação profissional nas escolas.

\begin{abstract}
A partir de $1^{\circ}$ de janeiro de 1941 , será exigido, para o exercício das funções de professor de educação física, nos estabelecimentos oficiais (federais, estaduais ou municipais) de ensino superior, secundário, normal e profissional, em toda a República, a apresentação de diploma de licenciado em educação física.

Parágrafo único - A mesma exigência se estenderá aos estabelecimentos particulares de ensino superior, secundário, normal e profissional de todo o país, a partir de $1^{\circ}$ de janeiro de 1943. (SÃO PAULO, 1985, p. 38).
\end{abstract}

Em 1945, esse modelo curricular sofreu uma reforma por meio do Decreto-lei no 8.270. Em relação aos saberes, a proposta segue o modelo do antigo currículo, apenas reorganizandoos. A exigência do diploma como pré-requisito para os cursos de educação física infantil, técnica desportiva e medicina aplicada à educação física e desportos foi uma das alterações significativas, embora continuasse pré-fixado o ensino secundário fundamental (antigo ginásio), para a submissão a uma vaga nos cursos de graduação, caracterizando a educação física até 1957 como um curso técnico, pois não se exigia o certificado do secundário complementar?.

A duração do curso de formação do professor passou de dois anos para três anos. Além disso, passou-se a exigir para a formação em Educação Física um currículo mínimo e um núcleo de matérias que contribuissem para a formação cultural e profissional.

Portanto, esses são os pilares do primeiro modelo de formação profissional em Educação Física que, em síntese, foi moldado com o objetivo de promover o adestramento físico dos jovens brasileiros tendo como finalidade educativa, a consolidação do modelo desenvolvimentista de Getúlio Vargas presente no que se convencionou chamar de "Estado Novo".

Ademais, esse modelo contribuiu para “... uma formação de cunho técnico-instrumental, excluindo - mais do que secundarizando - a estruturação de uma sólida base teórica de cunho humanístico (...) o que favoreceu a formação de profissionais acríticos” (CASTELLANI FILHO, 2013, p. 18).

\footnotetext{
${ }^{7}$ Nível educacional correspondente ao que é hoje considerado Ensino Médio.
} 
Esse modelo inspirará a formação em Educação Física até a década de 60, quando se iniciará um novo debate em torno das questões que envolvem a formação profissional nessa área.

\section{3 - Educação Física e democracia "populista": desdobramentos sobre a prática curricular}

O contexto socioeconômico que antecede a formulação do segundo modelo curricular de formação profissional em Educação Física é conhecido como democracia populista ${ }^{8}$. Estamos agora no processo de industrialização e internacionalização da economia em virtude da política "desenvolvimentista" do governo de Juscelino Kubitschek.

Com o processo de abertura política e democratização do país abrem-se, em todas as áreas sociais, possibilidades de diálogo com a população por meio dos seus representantes a fim de criar políticas públicas que viessem a atender aos clamores populares.

O grande marco desse momento foi a promulgação da Constituição de 1946 elaborada pela Assembleia Nacional Constituinte embora fosse de inspiração ideológica liberaldemocrática. Entre os avanços desta constituição, inclui-se a competência da União para legislar sobre as diretrizes e bases da educação nacional além de delegar aos estados a organização de seus sistemas de ensino, cabendo à União um caráter Supletivo.

Do ponto de vista educacional, temos a aprovação em 1961 da Lei de Diretrizes e Bases da Educação Nacional sob o número 4.024, após intenso debate assim caracterizado por Castellani Filho,

O que se deu, portanto, a partir daquela data até à promulgação, 13 anos depois, da Lei $\mathrm{n}^{\circ} 4.024$ - Lei de Diretrizes e Bases da Educação Nacional foi todo um debate em torno das questões atinentes à Educação Nacional. Centrado, num primeiro instante, na questão da organização dos sistemas de ensino - na qual despontavam duas posições divergentes, a primeira delas

\footnotetext{
${ }^{8}$ Octávio Ianni procurando analisar a história política brasileira e as razões do golpe civil-militar de 1964, publicou, em 1968, O colapso do populismo no Brasil. Nessa obra, Ianni vai delimitar temporalmente o populismo entre os anos de 1945 a 1964, período denominado de "democracia populista". Ademais, Ianni vê no golpe civil-militar de 1964 o resultado do esgotamento do "populismo" no Brasil, isto é, o colapso de um modelo de desenvolvimento econômico característico de um período de transição (de uma sociedade de base agrária para uma sociedade urbana e industrial) conduzido por um Estado intervencionista e por líderes carismáticos, que buscam legitimar-se através da política de massas. Ainda segundo Ianni, essa política de massas seria uma forma de organizar, controlar e utilizar a força política da classe trabalhadora, que, em virtude da sua origem rural, seu atraso cultural e sua inexperiência política, estava destituída de uma consciência de classe. Dessa forma, eram facilmente galvanizados e instrumentalizados pelas lideranças carismáticas.
} 
defendendo uma concepção centralizadora, aparentemente pautada ainda nos princípios presentes na Constituição de 1937, e a segunda, apoiada na Carta de 1946, deixando antever uma concepção federativo-descentralizadora dos sistemas de ensino - teve, a partir de 1958, uma mudança de enfoque no rumo das discussões, passando, em razão do substitutivo de Carlos Lacerda, a enfocar a questão do, nele denominado, monopólio estatal das "coisas" da Educação, atendendo às pressões contra esse monopólio, a interesses privatistas, o qual, por sua vez, contava com o respaldo das instituições confessionais, na busca de resgatar a sua influência na gerência das questões da educação. (1988, p. 79)

Embora tenha acontecido todo um debate dos segmentos representativos da educação autores como Romanelli (1984), Saviani (1983), Bergo (1979), avaliam que a referida lei não apresentou avanços significativos no que se refere às necessidades populares. Ao final, limitouse apenas à organização do sistema de ensino e, mais tarde, ajustando-se à continuidade "sócioeconômica" daquele período. De acordo com Romanelli apud Castellani Filho, intencionava-se adotar, “... em definitivo, as medidas para adequar o sistema educacional ao modelo de desenvolvimento econômico que então se intensificava no Brasil” (1988, p. 82).

Em relação à Educação Física, abre-se um grande debate em torno da revisão de paradigmas na área, tendo como principal reivindicação o processo de desmilitarização da Educação Física Escolar. Tendo como inspiração os conceitos da Escola Nova, questiona-se a homogeneização do Método Francês que não atendia a todas as fases do desenvolvimento humano. Portanto, o conceito Anátomo-fisiológico necessitaria ser modificado para um emergente conceito bio-psico-social da Educação Física. O objetivo era promover uma formação integral, em suas dimensões físicas, psicológicas e sociais.

Do ponto de vista prático, esperava-se que os antigos métodos puramente voltados para o desenvolvimento físico e da disciplina pudessem ser revistos, dessa vez com a introdução de práticas mais dinâmicas e menos enfadonhas e desinteressantes aos alunos. Os métodos deveriam, portanto, ser mais lúdicos e mais direcionados para a fase de desenvolvimento dos alunos.

Na esteira dessa revisão de paradigmas metodológicos da Educação Física, em que se busca destituir a antiga "ginástica" ${ }^{9}$ em prol de um método mais condizente com a realidade histórico-político vivida pelo país, surge com grande força o esporte.

...um método de Educação Física baseado no esporte, atendendo aos seguintes objetivos e características: saúde, pela melhoria das condições psico-morfofisiológicas; desenvolvimento intelectual, porque obriga o aluno a raciocinar;

\footnotetext{
${ }^{9}$ Designação para os métodos ginásticos largamente utilizados na Educação Física Brasileira.
} 
desenvolvimento moral, porque cria o hábito de vencer as dificuldades; é adaptável a todas as idades e sexos; permite a execução de lições atraentes e o professor é incentivado pelos resultados obtidos. (MUSA in BETTI, 1992, p. 96)

É importante destacar o descompasso entre as propostas metodológicas emergentes e o processo histórico do país. Embora estivéssemos saindo de uma ditadura e clamando por liberdade, por protagonismo social, etc, na Educação Física ainda conviveríamos com uma produção científica enraizada nas ciências biomédicas.

Portanto, não conseguimos nesse período avançar o suficiente para produzir métodos mais críticos que contribuíssem para o desenvolvimento das potencialidades humanas requeridas no momento.

$\mathrm{Na}$ ausência de proposições recorremos mais uma vez à Escola Francesa de Educação Física. Se no momento anterior prevaleceu o método francês, dessa vez, teremos a introdução do chamado método desportivo generalizado.

O Método Desportivo Generalizado visa proporcionar uma atividade física prazerosa e que englobe o indivíduo como um todo, numa ação psico-morfofisio-sociológica. Desejava-se, tendo em vista "a experiência, a psicologia da juventude e os conhecimentos filosóficos e científicos autais", substituir o exercício " feito por obrigação, pelo exercício executado por prazer ou por necessidade imperiosa". (BRASIL, MEC, DEF, p.1 in BETTI, 1992, p. 98)

Há de se ressaltar que, dessa vez, a contribuição da Escola Francesa será no sentido da contraposição aos velhos métodos ginásticos e de manter o esporte sob o domínio pedagógico da Educação Física, impedindo assim a sua completa esportivização ${ }^{10}$ (BETTI, 1992).

No que se refere à estrutura e organização curricular da Educação Física Escolar teremos como principal novidade o Art. 22 da Lei 4.024/61 que determina a obrigatoriedade da sua prática nos cursos primários e médios, atual ensino básico, até a idade de 18 anos. Com relação à formação profissional em Educação Física temos em igual importância naquela LDB o Art. 70 que produzirá desdobramentos significativos em todas as licenciaturas

Art. 70. O currículo mínimo e a duração dos cursos que habilitem à obtenção de diploma capaz de assegurar privilégios para o exercício da profissão liberal ... vetado ... serão fixados pelo Conselho Federal de Educação.

\footnotetext{
${ }^{10}$ O neologismo "esportivização" deriva do que Norbert Elias (1992) denomina de "desportivização" ou o processo mediante o qual, os passatempos, divertimentos e jogos vão se convertendo em práticas institucionalizadas denominadas desportos, no âmbito da sociedade inglesa do século XIX, daí exportados em escala global como avanço civilizatório.
} 
Parágrafo único. Vetado.

(BRASIL, 1961)

Do ponto de vista da formação em Educação Física, a aprovação do currículo mínimo para os cursos de licenciatura em Educação Física e Desportos se daria no ano de 1962, por meio do parecer $n^{\circ} 298$ (BRASIL, CFE, 1962).

A adoção do currículo mínimo tinha como fundamento assegurar, em nível nacional, o acesso uniforme aos conteúdos culturais, sociais e biológicos da Educação Física em todos os cursos de formação da referida área.

Em sua dissertação de mestrado, o professor Nivaldo Nogueira David (2003) analisa a adoção do currículo mínimo em relação à formação comparando o currículo da ENEFD (1939) e seu rol de disciplinas, com o currículo da Escola Superior de Educação Física e Desportos, incorporada em 1958 no sistema estadual de ensino superior de São Paulo. Para ele, embora tenha aumentado a quantidade de disciplinas, o caráter biologicista e desportivizante permanece semelhante ao de 1939.

Nesse mesmo estudo, cita Silva (1983) para dar destaque aos aspectos inovadores dessa nova proposta curricular assim por ele descrito. “... o que se destaca nesse currículo e, de certo modo, o inovou, foi a presença da disciplina Educação Física Infantil, evidenciando, naquela época, uma preocupação com os conteúdos voltados para a atuação com crianças e para a escola primária na formação de recursos humanos (DAVID, 2003, p.30).

Há de se ressaltar a menção anterior em torno da redefinição de rumos na formação profissional e na concepção de Educação Física nesse novo momento histórico. A necessidade de se desvencilhar dos ranços de uma perspectiva anátomo-fisiológica em prol de uma concepção bio-psico-social da Educação Física se tornava evidente com a inclusão de disciplinas que permitissem aos professores, mesmo que parcialmente, compreenderem a complexidade da sua prática.

Ainda em torno da avaliação desse novo esboço curricular o professor Nivaldo David, conclui da seguinte forma:

À primeira vista, constituem mudanças importantes a introdução das disciplinas pedagógicas e uma certa redução das disciplinas técnicodesportivas, o que só comprova a coerência do projeto para atender aos princípios da Lei n. ${ }^{\circ} 4.024 / 61$, que previa a obrigatoriedade da Educação Física em todos os níveis e ramos de escolaridade, exceto no ensino superior. Com isto, sem sombra de dúvidas, a formação acadêmica estaria fortalecendose com elementos pedagógicos e metodológicos, com destaque para o estágio e a prática de ensino articulados à formação educativa da escola. ( 2003, p.30) 
Entretanto, não se consegue auferir qualquer tipo de avanço no campo pedagógico da formação em Educação Física em virtude da concepção biologicista da área, profundamente enraizada na prática dos professores formadores vinculados às estrutura responsáveis pela organizacão da Educação Física no país, fazendo prevalecer uma visão técnico-instrumental em relação à formação.

\section{4 - A Ditadura Militar e o segundo modelo curricular de formação profisssional em Educação Física}

A ambiência social em que se dá a aprovação do segundo modelo curricular de formação profissional em Educação Física é bastante autoritário e conflituoso. A expectativa de democracia popular criada pelos governos de Jânio Quadros e, a posteriori, de João Goulart e o não alinhamento aos Estados Unidos da América, foi visto como um risco de aproximação brasileira ao eixo soviético.

Se por um lado eram crescentes as manifestações públicas em torno dos direitos populares, a opinião pública se nutria do ideário da defesa da pátria e da segurança e integridade nacional. A ameaça comunista se fazia presente no país, corroborada pela guerra fria entre Estados Unidos e União Soviética. Nesse contexto, o regime instaurado pelo golpe militar em $1^{\circ}$ de abril de 1964 ganhou legitimidade entre os amplos setores da classe dominante e de grande parte da classe média brasileira. Dessa forma, haveria de se instaurar medidas que pudessem retomar o consenso e a normalidade política do sistema.

Em relação à política educacional, foram produzidas medidas que intencionavam privar os educandos de qualquer senso crítico, portanto, extinguindo do currículo disciplinas que viessem a promovê-la e, por outro lado, preparando-os instrumentalmente para agregar a mais valia aos detentores dos meios de produção. Nesse sentido, envidaram esforços no sentido de fortalecer a estrutura técnico-profissionalizante no país, além de medidas de controle do tempo livre do trabalhador com a proliferação de estruturas como o SESC, SESI, SENAI, etc.

Para fazer frente ao protagonismo universitário, principal opositor do regime, foi aprovada a Lei n 5.540 de 28 de novembro de 1968, conhecida como a Reforma Universitária. Em sua essência, buscava promover a desmobilização dos estudantes universitários e o processo de alienação com a retirada de disciplinas que promovessem quaisquer perspectivas de leitura crítica da realidade. Antes, no período de 1964 a 1968 sofreu a UNE todo tipo de repressão, sendo, por meio do Decreto $\mathrm{n}^{\circ} 57.634 / 64$, proibida de exercer as suas atividades por um período de seis meses. Como forma de promover e incentivar outras formas menos reativas de 
protagonismo estudantil, foi criada também em 1966 a Lei Suplicy n ${ }^{\circ} 4.464$ que, além de disciplinar a atividade das organizações estudantis, criava para substituir a UNE, o Diretório Nacional dos Estudantes (CASTELLANI FILHO, 1988).

Com relação à Educação Física, temos na mesma Lei de Reforma Universitária em seu artigo 40, letra C, o estímulo por parte das Instituições de Ensino Superior às atividades desportivas. Mais tarde, a publicação do Decreto Lei no 705 de 25 de julho de 1969 torna obrigatória a prática da Educação Física em todos os níveis e ramos de escolarização. Assim resume o professor Castellani Filho sobre a participação da Educação Física no ensino superior no referido período:

Nesse cenário, coube à Educação Física o papel de, entrando no ensino superior, por conta do Decreto-lei $n^{\circ} 705 / 69$, colaborar, através de seu caráter lúdico-desportivo, com o esvaziamento de qualquer tentativa de rearticulação política do movimento estudantil. Evidenciava-se, dessa forma, os traços alienados e alienantes absorvidos pela "personagem" vivida pela Educação Física. (1988, p. 95)

Portanto, a presença da Educação Física, contribuiu para o enriquecimento cultural esportivo sem, no entanto, contextualizar esse conhecimento com a realidade política enfrentada naquele momento no país. Nesse sentido, atendeu aos interesses do regime militar em promover a pacificação e o arrefecimento das tensões entre universidade e governo, sendo, a primeira, uma das principais instâncias de questionamento e reação à violenta repressão imposta pela ditadura militar de 64 .

Todavia, nos afastando da tentadora e legítima reflexão sobre os desdobramentos políticos do período militar e nos mantendo próximo daquilo que é o foco desse capítulo, isto é, avaliar historicamente os modelos curriculares de formação profissional em Educação Física e, levando-se em conta o contexto social em tela, destacamos a segunda perspectiva curricular para a formação na área. Regulamentada por intermédio do Parecer 894/69 e da Resolução no 69, de 06 de dezembro de 1969, do Conselho Federal de Educação (CFE) ${ }^{11}$, vem fixar o currículo mínimo dos Cursos de Educação Física. Segundo Pereira Filho,

(...) esse modelo nacional de currículo se caracterizava por um bloco de matérias obrigatórias, subdivididas em básicas e profissionais, que constituía o chamado currículo mínimo. Cada Instituição Superior de Educação Física teria a liberdade de complementá-lo de acordo com as características e necessidades de suas regiões. O curso passa a ter uma duração mínima de 1800

${ }^{11}$ Betti, 1992, p.114 
horas/aula, ministradas, no mínimo, em três anos e, no máximo, em cinco anos (2005, p.56).

Segundo Betti (1992), as Escolas de Educação Física articuladas pela DEF reuniramse e apresentaram um anteprojeto de currículo mínimo ao CFE. Preocupavam-se prioritariamente com a formação do técnico esportivo, em virtude da legislação vigente à época não ser exequível na maioria dos estabelecimentos de formação por não estarem aparelhados para manterem cursos com muitas especialidades esportivas. Com isso, o mercado de trabalho não era atendido nem em quantidade e nem em qualidade em suas demandas esportivas. Sugeriram, portanto, que a profissão de "técnico esportivo" prevista no Decreto Lei 1212, de 1939, fosse exercida pelos licenciados em Educação Física, cursando além das matérias obrigatórias do currículo mínimo, uma ou duas modalidades esportivas para a sua especialização. Assim, a formação em nível de graduação nessa área, a partir da Resolução CFE n ${ }^{\text {0 }}$ 9, passaria a conferir o título de Licenciado em Educação Física e Técnico em Desportos. Essa Resolução também listou seis matérias básicas da área biológica e seis matérias profissionais, além das matérias pedagógicas previstas no parecer 672/69. Acrescentando-se a esse elenco mais duas matérias de cunho esportivo, o aluno poderia obter também o título de Técnico Esportivo. No quadro abaixo temos um esboço esquemático dos saberes e da formação viabilizada por esse modelo.

\section{Quadro - II: Currículo de formação em Educação Física (1969)}

\begin{tabular}{|l|l|}
\hline \multicolumn{1}{|c|}{ Saberes } & \multicolumn{1}{|c|}{ Habilitação Profissional } \\
\hline $\begin{array}{l}\text { Estudo da vida humana em seus aspectos } \\
\text { celular, anatômico, fisiológico, funcional, } \\
\text { mecânico, preventivo }\end{array}$ & \\
\cline { 1 - 1 } $\begin{array}{l}\text { Estudo dos exercícios gímnico desportivos } \\
\text { em seus aspectos físicos, motores, lúdicos, } \\
\text { agonísticos, artístico }\end{array}$ & $\begin{array}{l}\text { Professor de Educação Física ou de forma } \\
\text { concomitante o Técnico Desportivo }\end{array}$ \\
\cline { 1 - 2 } $\begin{array}{l}\text { Estudo das matérias pedagógicas: didática, } \\
\text { estrutura e funcionamento do ensino, } \\
\text { psicologia da educação e prática de ensino }\end{array}$ & \\
\hline
\end{tabular}

Fonte: Adaptado de (SOUZA NETO et ali, 2004) 
É importante ressaltar que a antiga formação realizada em apenas dois anos passará, sob os auspícios dessa nova lei, para três anos de duração com uma carga horária mínima de 1800 horas-aula e redução das matérias básicas de fundamentação científica.

O professor João Bosco da Silva, autor da primeira dissertação de mestrado em Educação Física produzida no Brasil em 1983, junto ao programa de pós-graduação da Escola Superior de Educação Física da USP, faz uma análise da formação pautada na Resolução CFE 069/69.

Em seu trabalho busca analisar as relações existentes entre a legislação que orienta a formação dos especialistas em Educação e Desportos e os planos nacionais nas áreas educacional e desportiva chegando às seguintes conclusões:

a) Inexistência de debates, em termos filosóficos, científicos e legais não permitindo a discussão e reflexão que pudessem encaminhar soluções para os problemas da formação;

b) Projetos existentes na área educacional e desportiva voltados para o desenvolvimento do desporto de alto nível em detrimento das questões pedagógicas;

c) Influência da militarização dos processos pedagógicos e formativos.

Conclui, finalmente, que não houve avanços significativos entre esse modelo curricular e o último preconizado pelo Decreto Lei $n^{\circ} 1.212 / 39$ que criou a ENEFD.

Embasados nessas premissas e no contexto autoritário da época, pode-se afirmar que o modelo curricular implantado por essa legislação acabou garantindo os interesses do Estado no que se refere à massificação esportiva e coesão social. Não bastasse o engessamento proporcionado pelo currículo mínimo que não deixava brechas para a diversificação das matérias, as que existiam, promoviam uma formação incipiente, puramente voltada para as questões biológicas e esportivas. Parece-nos, estar aí, o requisito para a formação profissional da época e ainda presente nos currículos atuais.

Para nós, a qualidade e a consistência da formação profissional, podem ser traduzidas pela capacidade do aluno compreender criticamente a realidade concreta em que intervém pedagogicamente, sem a qual, contribuirá apenas para a reprodução das relações sociais vigentes. 
Isto posto, seguiremos na análise dos paradigmas curriculares da Educação Física, tendo como objeto a terceira perspectiva curricular da Educação Física em meio ao processo de redemocratização do país na década de 1980.

\section{5 - Reabertura política e a terceira proposta de formação curricular: o adeus ao currículo mínimo}

Após tenebrosos anos de ditadura militar, descortina-se no horizonte, mais uma vez, os ares da democracia. Com ele, um tempo de novas esperanças, de liberdade e de possibilidades de construção de um projeto popular para o país. Nesse sentido, a década de 80 no Brasil foi um período de significativas mudanças e de reordenamento no quadro político. O início do processo de abertura política, após longo período de ditadura Civil-militar, possibilitou o surgimento de novas organizações da sociedade civil e da sociedade política. A população foi mobilizada a participar dos destinos do Estado e a intervir nos diferentes níveis de governo.

O país, embora vivenciasse essa efervescência de mudança, convivia e ainda hoje convive com grandes contrastes sociais e econômicos, fruto de um modelo de sociedade extremamente excludente, em que a maioria da população não tem acesso aos bens sociais básicos $^{12}$, entre estes, a educação, saúde, saneamento básico e habitação.

Diante dessas condições surgirá, nos anos 80, um novo cenário político e social, por meio de organização de sindicatos, associações científicas e comunitárias, novos partidos políticos e organizações não governamentais que começavam a desenvolver ações que não eram assumidas pelo Estado.

No campo educacional o período caracterizou-se pelo questionamento à crise educacional a qual atravessava o país. Para termos uma ideia, em 1980, 26\% da população brasileira acima de 15 anos eram analfabetos. De cada 1.000 alunos que adentraram na $1^{\mathrm{a}}$ série do $1^{\circ}$ grau em 1969, apenas 178 concluíram a $8^{\text {a }}$ série e 110 o $2^{\circ}$ grau em 1980. Em diagnóstico feito à época, identificava como principais obstáculos à melhoria do desempenho escolar no Brasil, a evasão e a repetência, a falta de valorização do professor do $1^{\circ}$ grau, a centralização administrativa e a incipiente relação entre a escola e a sociedade (BETTI, 1991).

\footnotetext{
${ }^{12} \mathrm{O}$ Brasil ocupa um dos primeiros lugares no mundo em concentração de renda, e um dos mais baixos lugares na qualidade de vida da população.
} 
Em abril de 1984, milhões de brasileiros foram às ruas pleitear a realização de eleições diretas para presidente da República, um episódio que marcou o processo de redemocratização do Brasil. A Campanha das "Diretas Já" surpreendeu o país com as dimensões da mobilização popular alcançada. A reivindicação social por eleições diretas, contudo, resultou frustrada com a rejeição, no dia 25 de abril de 1984, pelo Congresso Nacional, da Emenda Dante de Oliveira, que previa a realização de eleições diretas para presidente da República. As eleições seriam, desse modo, mais uma vez indiretas.

A derrota no Congresso, porém, não significou a derrocada do processo político que conduzira à apresentação da Emenda do deputado Dante de Oliveira. Em artigo publicado em maio de 1984, Florestan Fernandes pondera que,

...em troca de uma 'derrota parlamentar', ganhamos um exército pronto para o combate político e, pela primeira vez em vinte anos, a ditadura não só foi virada pelo avesso, posta no pelourinho e desafiada por milhões de cidadãos conscientes e dispostos a tudo - foi batida dentro do campo da ordem ilegal que ela forjou" (1986, p. 179)

Como observou o Constituinte Juarez Antunes (PT -RJ) (Diário da Assembléia Nacional Constituinte, 15 de Maio de 1987, p. 1968): “O projeto de transição em curso estava previsto pelos militares. Uma transição lenta e gradual, limitada aos estratos dominantes, sendo altamente controlada. O objetivo era transferir o poder aos civis, sem ruptura, mantendo o modelo político-econômico".

Com relação à Educação Física, os anos 1980 inauguram uma nova fase em que se busca encontrar a sua identidade e sentido pedagógico outrora solapado pelos governos militares. No nível governamental temos a criação da SEED - Secretaria de Educação Física e Desportos em substituição ao antigo DED - Departamento de Educação Física e Desportos. Essa medida aparecia à sociedade como uma valorização da Educação Física naquela atual conjuntura, muito embora Faria Junior denunciasse mais tarde que "ao contrário do discurso oficial ufanista, essa importância não era tão grande, como se podia inferir das previsões orçamentárias do MEC para 1984, em que apenas 0,65\% era alocado para a educação física e os desportos" (1987, p. $62)$.

Com status de subsidiar a formulação de políticas públicas para a Educação Física e os Desportos, a referida secretaria adotou uma postura diferenciada, questionando o modelo de massificação esportiva, então conhecido como o modelo piramidal ${ }^{13}$, amplamente utilizado nas

\footnotetext{
${ }^{13}$ Sobre modelo piramidal, consultar Betti, 1991, p.59
} 
décadas de 1970 e parte da década de 1980. Em resposta a essa situação, em 1985, por meio do documento "Proposta da Política Nacional de Educação Física e Desportos 1986 - 1989" (BRASIL, MEC, SEED, 1085b), manifestou sua opção por um modelo de subsistemas, considerando o esporte em três dimensões: como fenômeno social, elemento no processo educacional e elemento de ocupação do tempo livre. Essas dimensões resultariam na conceituação do esporte sugerindo três manifestações: esporte-educação; esporte-participação e esporte-performance (BRASIL, 1986).

É importante salientar que essa postura representou grande avanço, definindo conceitos e objetivos próprios em cada subsistema esportivo. Entretanto, foram conservados ainda resquícios do modelo piramidal, ao recomendar-se que o esporte-educação seja também um meio de descoberta e desenvolvimento de futuros participantes do esporte-performance (BETTI, 1991).

No âmbito acadêmico-científico, a Educação Física experimenta a partir de 1982 uma grande efervescência no campo teórico-metodológico com a realização de vários congressos, simpósios e cursos de especialização com a participação de professores pós-graduados em Educação Física no exterior.

Citado por Betti (1991), as conclusões do II Congresso Estadual do Ensino Oficial do Estado de São Paulo, em 1983 apontaram para o seguinte diagnóstico da Educação Física

... tem sido historicamente usada, no Brasil, para reforçar condutas estereotipadas do homem e da mulher, contribuir para a segurança nacional e os interesses econômicos vigentes e para a repressão e desarticulação do movimento estudantil universitário, o que a descaracteriza como prática educativa. A Educação Física para esses fins "deve-se à sua origem militar e à influência que a categoria de médicos exerceu sobre a mesma" e levou à formação de "profissionais ingênuos, despreparados para exercer um legítimo papel educativo e facilmente manipulados por forças políticas das quais não tem consciência"(II CEEOESP apud BETTI, 1991, p. 125).

Portanto, vemos aqui o descontentamento por parte de entidades representativas da Educação Física, reiterada em outros documentos, em especial a "Carta de Belo Horizonte" 14, extraída do II Congresso Brasileiro de Esporte.

\footnotetext{
${ }^{14}$ Historicamente, "cartas" e "manifestos" são expressões de alguma vanguarda ou movimento organizador de uma nova ordem, em curso ou pretendida. Geralmente eles expõem sinteticamente os pontos essenciais da nova ideologia (ou da contra-ideologia), com o objetivo de ganhar adeptos, despertar simpatias ou influenciar politicamente. As cartas e manifestos podem também ser uma forma de protestar contra alguém, ou alguma coisa, preparada por um grupo insatisfeito. (FARIA JUNIOR, 2001, p. 19-31)
} 
Segundo Faria Junior (2001), a Carta de Belo Horizonte não era a expressão de nenhum movimento da Educação Física, tendo tido assim pouca repercussão entre a comunidade da Educação Física. Somente mais tarde seria reconhecida nos meios acadêmicos da área, constituindo-se em referência de vários livros, monografias, teses e dissertações.

O documento foi escrito por doze experientes professores de Educação Física com várias tendências político-ideológicas, sendo alguns defensores da Universidade Pública e gratuita e outros de interesses privatistas escolhidos por dirigentes da FBAPEF e APEFs. Portanto, é plausível reconhecer a contraditoriedade do documento que por um lado expressa a defesa intransigente da gratuidade e qualidade do ensino e, por outro, reivindica espaço para o avanço de medidas, sobretudo no processo de formação profissional, que atendam às exigências do suposto crescimento de um mercado de trabalho na área da Educação Física para além dos muros escolares.

Muito embora o documento faça um diagnóstico amplo das condições da Educação Física, nos interessa destacar o diagnóstico e as propostas referentes à formação profissional, dispostas abaixo:

Formação do Professor de Educação Física - Considerando-se:

- $\quad$ que há uma proliferação indiscriminada de cursos de Educação Física e uma mercantilização do seu ensino, o que compromete a qualidade da formação profissional;

- $\quad$ que existem, na legislação, dispositivos que permitem uma formação inadequada à realidade atual, deturpando-se, assim, o exercício da profissão de professor de Educação Física (escolas militares, cursos em nível de $2^{\circ}$ grau, licenciatura curta e programas de treinamento para leigos);

- que a exigência de um currículo mínimo - fruto do autoritarismo e intervencionismo do Estado na educação - tem-se revelado inibidor da qualidade dos cursos de formação, estimulando a fraude e a simulação;

- $\quad$ que os atuais currículos das escolas superiores de educação física estão defasados em relação às novas exigências da sociedade, que determinam um novo perfil para o professor de Educação Física;

- $\quad$ que esse novo professor de Educação Física deve apresentar condições de atuar nas novas demandas do mercado de trabalho, em empresas privadas, organismos públicos e entidades comunitárias, utilizando metodologias adequadas, que atendam á especificidade dos diversos campos de atuação, como a recreação, a dança, o desporto, a ginástica e outros;

- que a necessidade de permanente atualização e aperfeiçoamento de professores, após sua formação escolar, é imperativa,

Sugere-se:

- $\quad$ que haja uma preocupação com a qualidade do ensino, por parte das instituições formadoras do professor de Educação Física;

- $\quad$ que as associações de classe assumam sua responsabilidade no acompanhamento dessa formação profissional;

- que as universidades e estabelecimentos isolados de ensino superior, responsáveis exclusivos pela formação do professor de Educação Física, 
sempre no nível de licenciatura plena, tenham autonomia para elaborar seus próprios currículos;

- $\quad$ que se objetive, na formação de professores de Educação Física, um profissional generalista, com possibilidade de acesso à especialização, com uma consciência ética e democrática e a necessária competência técnica para atuar em sistemas formais e não formais, interpretando a realidade em que atuará e comprometendo-se com a construção de um novo modelo de sociedade;

- que sejam criados mecanismos para o controle da qualidade de programas de atualização, especialmente aqueles desvinculados da universidade e com finalidade exclusivamente lucrativa (FARIA JUNIOR, 2001, p. 19-31).

Em que pese os elementos contraditórios do texto, fruto da correlação de forças na composição do coletivo responsável pela escrita, cabe-nos analisar os principais pontos que irão influenciar o novo modelo curricular de formação em Educação Física. Iniciamos com o principal, que é o questionamento em relação ao currículo mínimo. Desse modo, no terceiro ponto, denunciam "que a exigência de um currículo mínimo - fruto do autoritarismo e intervencionismo do Estado na educação - tem-se revelado inibidor da qualidade dos cursos de formação, estimulando a fraude e a simulação". Aqui poderíamos comentar o seguinte: Não seria responsabilidade constituicional do Estado a elaboração/execução/normatização de políticas educacionais? E mais, para nós representaria um grande equívoco deixar o mercado regular a formação profissional.

Mais à frente, sugerem "que as universidades e estabelecimentos isolados de ensino superior, responsáveis exclusivos pela formação do professor de Educação Física, sempre no nível de licenciatura plena, tenham autonomia para elaborar seus próprios currículos". Duas questões importantes, a defesa da licenciatura plena ${ }^{15}$ e o questionamento ao currículo mínimo com a consequente reivindicação da autonomia por parte das universidades e instituições superiores no processo de elaboração curricular, outrora restringida pela ditadura militar. Esses aspectos, mais tarde, serão levados em conta na construção da nova Resolução CFE nº 03 em 1987.

Outra preocupação do referido coletivo foi a falta de adequação do currículo de formação profissional aos interesses do emergente mercado de trabalho ${ }^{16}$. Dois pontos da

\footnotetext{
${ }^{15}$ A utilização do termo licenciatura plena se dá em contraposição à até existente licenciatura de curta duração.

${ }^{16}$ Pelos debates sobre a formação de professores na conjuntura daquela época, percebe-se que os cursos de licenciatura em Educação Física eram pressionados pelas novas determinações do mercado e pelo surgimento das novas ocupações de trabalho, com destaque para aqueles criados em razão dos interesses do processo de esportivização e das novas práticas corporais decorrentes de academias, clubes, serviços
} 
carta são dedicados a esse tema e devem ser analisados com bastante rigor em virtude destes impactarem, em nossa visão, negativamente o currículo. Explicitando melhor essa visão, me amparo na assertiva do professor Mauro Betti que adverte para o fato de que,

Equivocadamente, alguns de nós julgam que valorizam a licenciatura transformando-a numa imensa coleção de disciplinas ligadas a recreação, dança, esporte etc., de conteúdos necessariamente superficiais em função dos limites da carga horária. Licenciatura em Educação Física têm fracassado, fundamentalmente, porque seu foco prioritário de estudo não está na préescola e nas escolas de $1^{\circ}$ e $2^{\circ}$ graus, e na utilização das atividades físicas dentro delas, mas em outra parte qualquer onde o aluno possa futuramente encontrar emprego [...] (BETTI, 1987, p. 249-250).

Portanto, a tão ressaltada necessidade de adequação dos currículos ao mercado de trabalho compromete a qualidade da formação na medida em que transforma os currículos num amontoado de disciplinas, desarticuladas entre si e, invariavelmente, com abordagem instrumental, dificultando com isso a apropriação crítica da essencialidade da sua prática, que é a intervenção pedagógica.

Tendo em vista o cenário de discussões da época em relação à formação profissional, podemos concluir que os principais limites atribuídos ao currículo eram a crítica ao currículo mínimo que dificultava a adequação da formação tanto numa perspectiva mais crítica como voltada para os interesses do mercado de trabalho. A defesa da divisão da formação, abrindo espaço para uma especialização nas áreas mais técnicas com vistas ao mercado de trabalho, aventando com isso, a possibilidade de criação do bacharelado, posição defendida por grupos privatistas e, por outro lado, a defesa da formação generalista com possibilidades de atuação na escola e fora dela. Para melhor elucidação do conjunto das posições sobre a configuração curricular da formação em Educação Física recorremos à seguinte síntese:

De um lado, existia um grupo de especialistas que defendia a manutenção da licenciatura naquela perspectiva ampliada, de formação generalista. Este grupo respaldava-se no argumento de que em todos os campos de trabalho da

de atendimento personalizados, dentre outros. Começavam então a surgir elementos novos e/ou alternativos para atender aos alunos ante as novas exigências de trabalho colocadas para a IES. Novos cursos de atualização, cursos técnicos ligados ao esporte, novas disciplinas opcionais voltadas para assuntos do cotidiano, novos campos de estudos dedicados ao treinamento desportivo, administração esportiva, direito esportivo, dentre outros e novas frentes de pesquisas aplicadas, davam provas de que as novas transformações do processo produtivo e a organização do trabalho, tanto em escala internacional quanto locais, apresentavam os primeiros sinais do esgotamento do modelo de currículo mínimo estabelecido pelo CFE (DAVID, 2003, p. 39). 
Educação Física Escolar (escolar e não-escolar), o profissional exercia uma intervenção essencialmente pedagógica. A dinâmica da intervenção profissional pressupunha um indivíduo que ensinava, um conteúdo/conhecimento/habilidade de ensino e um ou mais que aprendiam. Este profissional era um professor, independentemente da especificidade do campo de atuação. Por outro lado, existia um grupo de especialistas que defendia uma outra titulação para a Educação Física. Idealizava-se a formação de um profissional mais qualificado e especializado para atuar nos diferentes campos de trabalho denominados de não-escolar. Este grupo amparava seus argumentos em prol de uma outra titulação, na finalidade genuína dos cursos de licenciatura que em termos legais, deveriam qualificar e habilitar somente aqueles que queriam atuar na educação escolar. Neste sentido era necessário dar respaldo e melhor formação àqueles que queriam atuar profissionalmente fora do âmbito escolar.(KUNZ et ali. 1988, p. 39)

Em 16 de junho de 1987, após oito anos de discussões envolvendo toda a comunidade da Educação Física, foi implementado o terceiro modelo curricular de formação com a publicação da Resolução CFE $n^{\circ}$ 03/87, dando total autonomia às instituições formadoras para criarem seus próprios currículos.

Quanto à estrutura curricular, os cursos de Educação Física passariam a compreender duas partes: Formação Geral (em bases científicas, considerando os aspectos humanísticos e técnicos) e Aprofundamento de Conhecimentos (realização de pesquisas e estudos teóricos de acordo com as possibilidades de cada ISEF). Ainda nessa resolução, aparece pela primeira vez a possibilidade de titulações em Licenciado em Educação Física e ou Bacharel em Educação Física. No quadro abaixo, podemos visualizar melhor a referida configuração curricular:

\section{Quadro - III : currículo de formação em Educação Física (1987)}

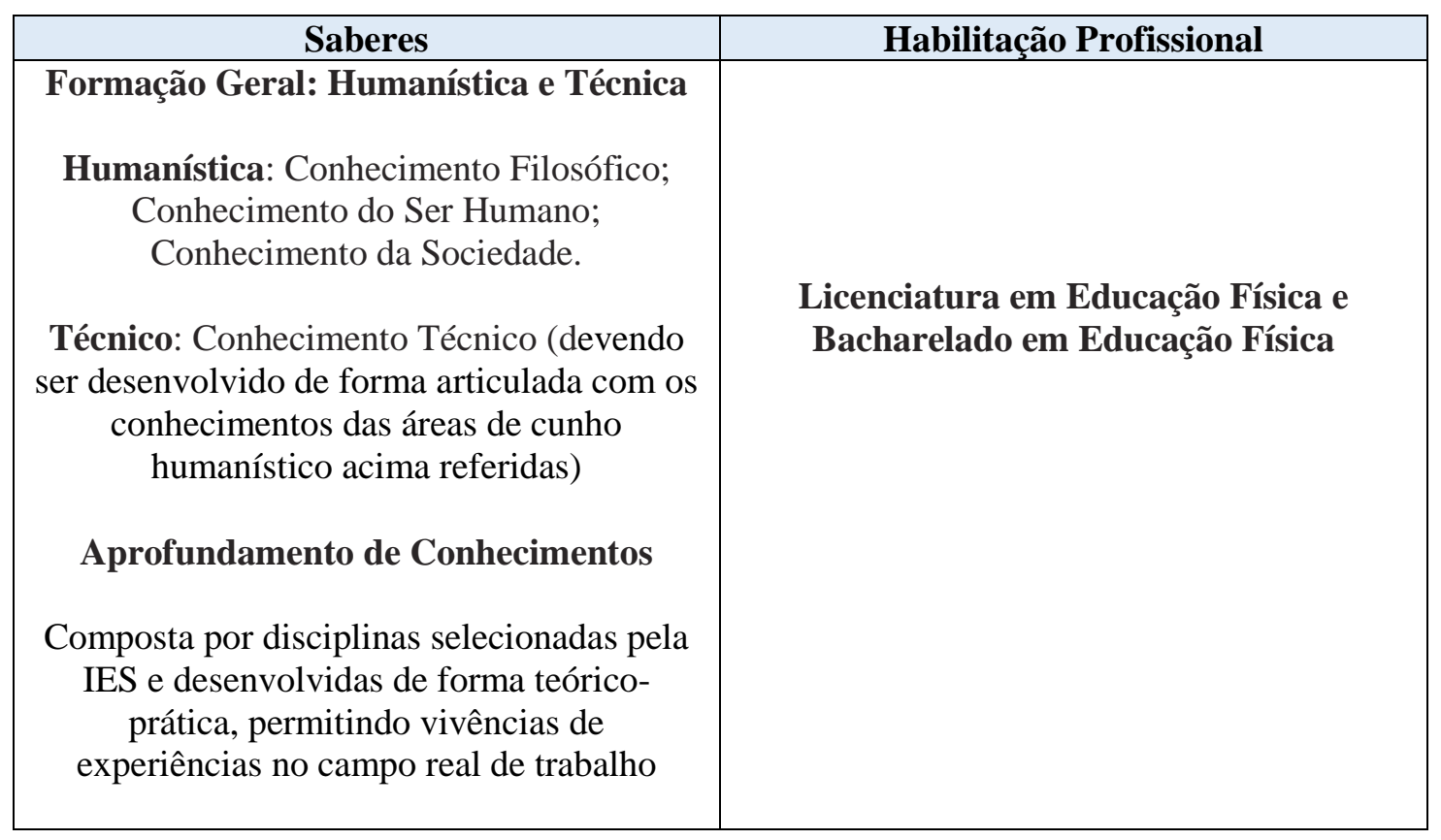


Fonte: Adaptado de (SOUZA NETO et ali, 2004)

É importante ressaltar que o bacharelado proposto na Resolução 03/87 era integrado à licenciatura, diferente do proposto pela atual Resolução 07/2004, que apresenta duas formações distintas com integralidade e terminalidade próprias.

Dois aspectos merecem também destaque em relação à configuração curricular. A primeira é que a carga horária do curso das 1.800 horas-aula anteriores amplia-se para 2.880 horas-aula. O segundo refere-se ao prazo para integralização curricular que salta dos antigos três anos para um prazo mínimo de quatro anos, tanto para o bacharelado quanto para a licenciatura, estabelecendo, assim, uma nova referência para a formação profissional.

Sobre esse modelo curricular é válido ressaltar que representa um divisor de águas em relação à formação profissional em Educação Física. Além disso, existe elevado consenso quanto às significativas mudanças por ocasião da sua concretização. Nesse sentido,

Pode-se verificar, com base na história da formação de professores de Educação Física, que somente com o estabelecimento da Resolução $\mathrm{n}^{\circ}$ 03/CFE/87 o projeto curricular sofreu mudanças profundamente importantes e diferenciadas de toda a trajetória da Educação Física. Embora se confirme que houve continuidade quanto à instituição de duas habilitações/titulações para a graduação em Educação Física, de um lado, ficou reconhecido que a Educação Física desempenha um papel importante no sistema educacional como instrumento de formação de hábitos e de comportamentos moral, cívico, cultural e político em todos os níveis de escolaridade da criança e do jovem brasileiro; de outro, expressa-se o entendimento de que as ações da educação física não se limitam ao espaço escolar, mas em diversas práticas, envolvendo tempo e espaços sociais, com expressões notoriamente reconhecidas no campo da saúde, do esporte, do lazer e das diversas práticas corporais existentes, sob a forma de linguagens. (DAVID, 2003, p. 43)

A despeito da afirmação do professor Nivaldo David, é importante destacar que a ideia do bacharelado trazida pela Resolução CFE nº 03/87 está muito mais associada à pesquisa do que à docência nos espaços não escolares. É importante também destacarmos e analisarmos alguns limites vinculados à esse modelo curricular. O principal deles ou, talvez, o mais questionado, refere-se à dupla possibilidade de formação com praticamente o mesmo currículo, mudando-se apenas a terminação dos cursos. Seria por assim dizer um aprofundamento em determinadas áreas do mercado profissional, como: desporto, lazer, administração esportiva, condicionamento, etc.

A COESP - Comissão de especialistas, criada para avaliar esse modelo curricular e esboçar um parecer com vistas à criação de um novo marco organizativo para a formação em Educação Física, “... informa que grande parte dos cursos reconhecidos ou em processo de 
solicitação de abertura de cursos propõe duas titulações com uma única estrutura curricular" (Kunz et al, 1998). Além desse aspecto podemos analisar, quanto a divisão da formação profissional em Licenciatura e bacharelado, a rejeição de parte de setores progressistas quanto a sua vinculação à interesses de grupos privatistas vinculados à Educação Física, porém, pertencentes à uma realidade urbana não condizente com o restante do país. Nesse sentido, Faria Junior $(1987,1992)$ vai defender a formação do professor generalista. Em sua visão o professor generalista é compreendido como o profissional formado sob uma perspectiva humanística, com licenciatura plena em Educação Física, podendo atuar tanto em sistemas educacionais formais quanto em não-formais. Ainda para o professor a justificativa para a criação do Bacharelado,

[...] calca-se numa visão do profissional de Educação Física, para as necessidades de uma realidade urbana, de cidades de grande e médio porte, apontadas, em pesquisas sobre mercado de trabalho, utilizando-se amostras não representativas. Nos países pobres e subdesenvolvidos do terceiro mundo, como o Brasil, tem-se defendido com propriedade, a formação inicial dos profissionais da área de educação, com perspectivas generalistas (FARIA JUNIOR, 1987, p. 26-27).

Portanto, observamos que por mais que tenhamos avançado com a Resolução $n^{\circ}$ 03/87 em relação aos aspectos curriculares de modelos anteriores, as avaliações apresentadas demonstram ainda limites significativos no que se refere à estrutura curricular. A tentativa de abarcar as especificidades e necessidades da formação em licenciatura e bacharelado num mesmo currículo acaba fragilizando a formação dos futuros professores. Esse, sem dúvida, é um dos aspectos que merece atenção de todos nós, pois a aposta feita atualmente no que se convencionou chamar de licenciatura ampliada ${ }^{17}$ embora anuncie uma formação de caráter

\footnotetext{
${ }^{17} \mathrm{O}$ termo Licenciatura ampliada ou unificada, vem sendo defendida por parte de setores críticos da Educação Física e das representações estudantis. Dentro desta concepção de formação de professores e formação humana, a Licenciatura Ampliada está fundamentada na [...] docência sobre a base do domínio de três eixos chave. O primeiro é o domínio dos Macro-conceitos da área (Esporte, Saúde, Lazer, Ginástica etc.). O segundo trata do domínio dos fundamentos para o trato com o conhecimento (Teoria do conhecimento X teoria da aprendizagem - como o conhecimento é construído e como se aprende); e o terceiro diz respeito ao domínio dos elementos específicos da docência (Organização do trabalho pedagógico - teoria pedagógica X metodologias específicas). Este tripé, caso não esteja articulado, estarão comprometidas às possibilidades de atuação dos futuros professores. (TAFFAREL e SANTOS JÚNIOR, 2010, p. 38).
} 
ampliado tentando abranger o todo da formação com ênfase nos aspectos político-pedagógicos, se depara com uma realidade contraditória. Se fizermos mediações com os espaços formativos poderemos perceber que, onde existem experiências com cursos de licenciatura ampliada e, nesse trabalho apresentaremos um estudo a respeito da realidade do curso de Educação Física da UNEB de Guanambi, a proposta se apresenta com uma série de limites, seja na apropriação e interpretação da sua concepção formativa em virtude das diversas linhas de trabalho dos atores pertencentes à esses espaços formativos, seja na própria gênese da criação do currículo que, semelhante ao exemplo de Guanambi, foram criados a partir da combinação das Resoluções CNE/CP 01 e 02 e Resolução CFE 03/87, produzindo currículos hibridizados, termo este discutido com maior profundidade no capítulo III desse trabalho.

A nossa hipótese é que as Licenciaturas Ampliadas realmente existentes têm trabalhado para oferecer uma formação generalista, superficial e pragmática, voltada muito mais para o atendimento da demanda emergencial do mercado de trabalho da Educação Física. Nesse sentido, a unificação não se dá em torno de uma compreensão da totalidade do conhecimento da Educação Física Física tomando-a como referência a docência, ao contrário, acontece visando o domínio de conhecimentos, técnicas e habilidades que abranjam as áreas de atuação profissional da Educação Física, notadamente localizadas mais fora da escola do que dentro.

Portanto, entendemos que o termo Licenciatura Plena seria mais adequado para darmos ênfase a uma formação ampliada. Na verdade a Licenciatura Plena veio em substituição ao termo Licenciatura Curta que não abrangia todos os conhecimentos necessários à uma formação ampla e contextualida. A licenciatura ampliada ou unificada, que tem como finalidade principal fazer o contraponto aos novos projetos elaborados sob a égide das atuais diretrizes, parece indicar muito mais o domínio de conhecimentos voltados para a atuação profissional do que em se consubstanciar como uma formação ampliada.

Outra análise possível é que um dos fatores que impedem essa pretensa qualidade reside no elevado número de conhecimentos e habilidades passíveis de serem dominadas pelos alunos. Ademais, diante de tantas demandas, o processo de aquisição do conhecimento acaba se tornando fragmentado e desarticulado. A esse respeito, poderíamos fazer uma analogia com outras áreas de formação profissional. Um exemplo emblemático para nós seria o curso de Pedagogia que, semelhante à Educação Física, também se apresenta com características generalistas, desde a especificidade do conhecimento por meio do qual o aluno irá organizar e estruturar a sua prática pedagógica, como o domínio de várias áreas de conhecimento: português, matemática, história, geografia, ciências, Educação Artística, Educação Física, etc. 
Ainda assim, abre-se possibilidades para atuar como docente (sala de aula) e bacharel (Supervisão Pedagógica, Orientação Pedagógica, Administração Pedagógica, etc).

Embora, existam todas essas possibilidades, a organização e a estrutura curricular são previamente pensadas e materializadas no sentido de particularizar as diversas atuações. Nesse sentido, existe uma formação em docência para atuar na Educação Infantil, nos Anos Iniciais do Ensino Fundamental e uma formação para atuar no nível de bacharel como Supervisão, Orientação, Administração, etc.

Ao contrário da Educação Física, a discussão da área da pedagogia vinha se dando no sentido de dar materialidade no currículo da pedagogia em relação às duas áreas de atuação, ou seja, de dividir a atuação profissional em Licenciatura e Bacharelado. Assim como na Educação Física e, a partir dessa divisão, existem esforços também no sentido da regulamentação da profissão. O que vem se consubstanciando no cenário acadêmico da área é a homogeneidade das análises que apresentam, invariavelmente, uma relação de causalidade entre o modelo capitalista atual e suas determinações sobre a formação de professores. Diante disto, parece claro que existe relação entre economia política e políticas públicas na configuração dos modelos de formação profissional de acordo com as características de cada contexto históricosocial. Marx chama a atenção para o fato de que quando analisamos a particularidade de um determinado objeto é preciso levar em conta suas contradições internas, os limites estruturais dos cursos superiores na formação de professores, a estrutura física e as diferentes formas de relações humanas existentes. Nesse sentido, a formação profissional se dá no conjunto das determinações complexas em que as contradições inerentes a elas repercutem tanto num sentido geral como no particular. Não podemos analisar apenas as determinações políticas e econômicas que incidem sobre a formação profissional, o que é bastante importante, entretanto, devemos tentar compreender as nuances do processo de constituição dos documentos legais que, inequivocamente são determinadas política e economicamente e, sobretudo, no processo de objetivação dessas diretrizes no interior de cada instituição, para somente aí, sabermos quais de fato são as variáveis que determinam a formação dos nossos professores de Educação Física.

Portanto, queremos conferir essa conotação ao trabalho, analisando como se dá a formação na prática cotidiana dos cursos, com os seus limites e contradições. A história da formação não para aqui. No próximo capítulo, faremos uma análise histórica das principais questões associadas à formação profissional, tendo como referência, um período compreendido entre 1990 a 2013. O nosso intuito é situar o debate em torno da formação profissional nesse período identificando aspectos que fizeram parte da crítica ao modelo de 1987, possíveis elementos inspiradores para o modelo atual, Resolução CNE/CES nº 07/2004 e Resoluções 01 
e 02/2002. Ainda no período, analisaremos a crítica ao modelo atual em busca de relações com as críticas/ reivindicações anteriores. Para tanto, ainda nesse trabalho, estudaremos o curso de Educação Física da UNEB-Campus XII em Guanambi-BA que possui um modelo curricular semelhante à licenciatura ampliada nos moldes da formação generalista, muito embora apresente aspectos inovadores em sua configuração curricular emanadas pelas Resoluções CNE/CP 01 e 02/2002. 


\section{CAPÍTULO 2 - O DEBATE ACADÊMICO-CIENTÍFICO SOBRE AS DIRETRIZES CURRICULARES DE FORMAÇÃO EM EDUCAÇÃO FÍSICA A PARTIR DA DÉCADA DE 1990}

A aprovação do quarto e atual modelo curricular da Educação Física vêm sendo objeto de questionamentos por uma grande parcela de pesquisadores do campo da Educação Física. Autores como Taffarel (2005), David (2003), Ventura (2010), Nozaki (2006), Molina (1998) e outros, apontam para um suposto pragmatismo do processo de formação profissional a partir das novas Diretrizes Curriculares, tanto a que se refere à Licenciatura (Resolução CNE/CP n ${ }^{\circ}$ 01 e 02/02) quanto à do bacharelado(Resolução CNE/CES no 07/04). Em suas formulações teóricas, estabelecem nexos entre o atual modelo de formação profissional para a Educação Física e o avanço do capital sobre o trabalho ao final do século XX e início do século XXI no Brasil. Em consonância com essa posição de natureza ideológica, defendem a revogação das atuais diretrizes supostamente causadoras da divisão da formação em Educação Física em licenciatura e graduação/bacharelado e a proposta de formação por meio da Licenciatura Unificada ou ampliada. Sobre isso, gostaríamos de observar que a licenciatura ampliada ou unificada estabelece como referência curricular a atuação profissional na medida em que colocam como principal argumento a destituição do direito dos trabalhadores da Educação Física de atuarem em seu vastíssimo campo que inclui a área escolar e não-escolar. O nosso entendimento é que licenciatura ampliada não é o mesmo que formação ampliada. A primeira se refere aos campos de intervenção profissional, ou seja, uma formação profissional que abranja todos os campos de atuação profissional e a segunda, formação ampliada, se refere ao aprofundamento e consistência do processo de formação profissional.

Ainda sobre o embate acadêmico-científico em torno das atuais diretrizes de formação profissional em Educação Física, destacamos os pesquisadores que buscam analisar a formação reconhecendo as suas relações com a economia no modo de produção capitalista, porém entendendo que existem outras variáveis capazes de interferir neste processo. Compreendem, inclusive que as atuais diretrizes curriculares apresentam limites associados à lógica capitalista, entretanto, procuram, embasados na teoria curricular e a partir do local onde as experiências curriculares acontecem, reconhecer seus limites e, também, identificar suas possibilidades em relação à superação desta lógica.

Na primeira perspectiva de análise, os aspectos políticos que envolvem a vinculação das diretrizes curriculares a uma lógica neoliberal são mais enfocados. Nesse sentido, a estratégia 
adotada por esses intelectuais é a negação da lei e o permanente estado de mobilização em torno da sua revogação e aprovação de uma nova resolução de caráter ampliado. Já a segunda, compreendendo os limites históricos na correlação de forças políticas para a aprovação da lei e, consequentemente, a sua natureza contraditória, dá prosseguimento à sua luta no espaço de formação profissional numa espécie de subversão à lei, na medida em que investiga os seus limites e possibilidades na prática curricular, desde o processo de elaboração dos currículos até à sua execução, definindo estratégias que possibilitem uma formação mais humana e crítica para os alunos.

Em nossa compreensão, essa divisão acontece em virtude das diferentes formas de apropriação do referencial marxista. Por um lado a análise fatorialista em que a economia política se torna o principal determinante das relações sociais e culturais da sociedade. Com isso,

\begin{abstract}
Marx aparece geralmente como um teórico fatorialista - ele teria sido aquele que, na análise da história e da sociedade, situou o " fator econômico" como determinante em relação aos "fatores" sociais, culturais, etc. Também Engels, em carta de setembro de 1890, já advertira contra essa deformação: recordando que Marx e ele sustentavam tão somente a tese segundo a qual a produção e a reprodução da vida real apenas em última instância determinavam a história. (PAULO NETTO, 2011, p. 13-14).
\end{abstract}

Por outro lado, busca-se utilizar outras categorias de análise da realidade como a contradição, mediação e particularidade que nos possibilita interpretar e identificar com maior rigor as verdadeiras propriedades do objeto, ou seja, seu movimento e essência.

Buscaremos aqui, avaliar a discussão curricular em torno das novas diretrizes levando em conta o contexto mais geral da sociedade e seus processos históricos. Nesse sentido, analisaremos as Reformas Educacionais, mais especificamente no âmbito da Educação Superior, tentando alocar esse processo no contexto da reestruturação produtiva do final do século XX e início do século XXI determinada pela crise do capitalismo a partir da década de 1970. Analisaremos, também, a evolução das discussões sobre formação no campo da Educação Física. Embora tenhamos feito um estudo histórico dos modelos curriculares anteriores, é importante, diante da atual polêmica em torno das diretrizes da Educação Física, analisar mais detidamente a produção de conhecimento de 1990 a 2013, fazendo um balanço das principais discussões/reivindicações sobre a formação após o modelo de 1987e antes e após o modelo de $2002 / 2004$. 
Reconhecendo a correlação de forças políticas que expressa projetos antagônicos de sociedade no interior do campo da Educação Física, recorreremos à história a fim de analisar o processo de constituição das diretrizes buscando desmitificar questões como a vinculação direta da aprovação da diretriz de graduação da Educação Física (Resolução CNE/CES nº 07/2004) ao Conselho Federal de Educação Física (CONFEF). Nessa mesma linha, revelar o protagonismo de agentes e grupos que, mesmo em condições adversas, defenderam posições importantes ao longo do processo que redundaram no avanço da atual diretriz, sobretudo quando comparada ao Parecer CNE/CP n ${ }^{\circ}$ 138/02, reconhecidamente conservador e repudiado por todos os setores críticos da Educação Física.

Ao final, tentaremos refletir sobre as atuais diretrizes curriculares da Educação Física enquanto marco legal, mas também contraditório e inacabado, reconhecendo os seus limites e identificando avanços e possibilidades no processo de formação profissional que não estejam restritos apenas ao currículo escrito, mas sobretudo ao currículo vivido, à experiência no processo de execução curricular e suas contradições históricas.

\section{1 - Crise do capitalismo, neoliberalismo e as Reformas na Educação Superior no Brasil}

A formação profissional em Educação Física vem sofrendo nos últimos tempos os efeitos daquilo que se convencionou chamar de "capitalismo tardio" 18 (MANDEL, 1982). Nesse contexto, em que as taxas de lucros são reduzidas, emergem reações da classe dominante em termos paradigmáticos no modo de produção capitalista. Essas transformações societárias serão, portanto, objeto de análise cuidadosa a fim de levarmos em consideração as suas determinações sobre as relações sociais, mas não tendo somente elas como explicação dos fatos sociais.

O capitalismo enquanto sistema social, historicamente tem evoluído por meio de crises cíclicas. Assim,

\footnotetext{
${ }^{18}$ Seguindo uma periodização do capitalismo, Mandel (apud BEHRING, 2009:23) denomina o período atual como capitalismo tardio, época em que suas tendências de desenvolvimento alcançaram a maturidade e suas contradições estão ainda mais latentes, promovendo como nunca, efeitos regressivos. Insere-se numa fase do capitalismo denominado de imperialismo, onde o capital financeiro possui centralidade. Os traços principais do imperialismo são: 1) a concentração da produção e do capital levada a um grau tão elevado de desenvolvimento que criou os monopólios, os quais desempenham um papel decisivo na vida econômica; 2) a fusão do capital bancário com o capital industrial e a criação, baseada neste capital financeiro, da oligarquia financeira; 3) a exportação de capitais, diferentemente da exportação de mercadorias, adquire uma importância particularmente grande; 4) a formação de associações internacionais monopolistas de capitalistas, que partilham o mundo entre si; e 5) o termo da partilha territorial do mundo entre as potências capitalistas mais importantes.
} 
...é preciso ter em mente que as novas forças de produção e relações de produção não se desenvolvem a partir do nada, não caem do céu, nem das entranhas da ideia que se põe a si própria; e sim no interior e em antítese ao desenvolvimento existente da produção e das relações de propriedade tradicionais herdadas. Se no sistema burguês acabado cada relação econômica pressupõe outra sob a forma econômica-burguesa, e assim cada elemento posto é ao mesmo tempo pressuposto, tal é o caso em todo sistema orgânico. Este próprio sistema orgânico, enquanto totalidade tem seus pressupostos e seu desenvolvimento, até alcançar a totalidade plena, consiste, precisamente, na subordinação de todos os elementos da sociedade a si próprio, ou na criação, a partir dele, dos órgãos que ainda lhe fazem falta; desta maneira chega a ser historicamente uma totalidade (MARX, 1983, p. 278).

Nesse sentido, é possível identificar ao longo dos últimos dois séculos (XIX e XX) crises que exigiram por parte do Estado, enquanto representante legítimo dos interesses da classe dominante mediados por seus intelectuais, soluções do ponto de vista da economia política a fim de assegurar as condições de exploração e, em tempos de insatisfação popular, contornos dóceis e menos hostis a um sistema completamente desumano.

Podemos destacar como primeira crise do capitalismo a que aconteceu em meados do século XIX, caracterizada pelas péssimas condições de vida e de trabalho enfrentadas pelos trabalhadores da época como: condições insalubres nas fábricas, jornadas de trabalho de 13 a 16 horas diárias, exploração de mulheres e crianças, etc. Associado a isso, as condições urbanas nas cidades e a falta de assistência à saúde por meio de políticas públicas adequadas, fez precipitar uma série de epidemias em toda a Europa, gerando a barbárie total.

O movimento operário de 1848 representa uma reação da classe trabalhadora, um levante contra as classes dominantes da época, muito embora tenha sido sufocado com violência descomunal. A contra-hegemonia ${ }^{19}$ em alguma medida serviu para que a burguesia buscasse estabelecer medidas capazes de remodelar o sistema produtivo e conter a insatisfação popular. Moralização sanitária, redução da jornada de trabalho, proibição do trabalho feminino e infantil foram algumas das políticas adotadas resultantes dessas lutas. Contraditoriamente, também serviram para a legitimação do status quo. Muitas outras crises econômicas e sociais aconteceram ao longo do século XX, entretanto,

\footnotetext{
${ }^{19}$ Gramsci situa as ações contra hegemônicas como "instrumentos para criar uma nova forma éticopolítica", cujo alicerce programático é o de denunciar e tentar reverter as condições de marginalização e exclusão impostas a amplos estratos sociais pelo modo de produção capitalista. ( 1999, p. 314-315)
} 
Vivemos na era de uma crise histórica sem precedentes. Sua severidade pode ser medida pelo fato de que não estamos frente a uma crise cíclica do capitalismo mais ou menos extensa, como as vividas no passado, mas a uma crise estrutural, profunda, do próprio sistema do capital. Como tal, esta crise afeta - pela primeira vez em toda a história - o conjunto da humanidade, exigindo, para esta sobreviver, algumas mudanças fundamentais na maneira pela qual o metabolismo social é controlado. (MÉSZÁROS, 2000, p.7)

Para cada crise uma correspondente transformação na economia política com repercussões sociais, sobretudo nas relações entre o trabalho e o capital. Mészáros (2009) nos diz que o capital respondeu à diversas crises, inclusive trazendo guerras mundiais antes impensáveis, aceitando o que ele definiu como "hibridização" a partir da crescente intromissão do Estado no processo econômico de produção como um forma de superar suas dificuldades, ignorando os perigos que essas intervenções podem acarretar em longo prazo.

Compreendendo que a atuação do Estado em tempos de crise do capital tem contribuído para a formação de um sistema hibrido e que, em sua essência, não corresponde à forma clássica do capitalismo, podemos inferir que, nessa hipótese, existe um capitalismo latente, muito mais nocivo do que se apresenta e que tende a eclodir em proporções jamais vista. O suposto é de que estamos muito mais próximos da barbárie do que de um sistema político-econômico que valorize de fato os seres humanos. Parece ser esse o tempo que vivemos a partir da crise do final do século XX conforme nos relata Carvalho (2003, p. 36):

Os acontecimentos que se vêm manifestando, desde o começo dos anos 70, sinalizam para o esgotamento do conjunto das relações comerciais, produtivas, tecnológicas e financeiras desse período, sinalizando para uma nova fase, ainda difícil de apreender, mas que revela um ambiente de instabilidade financeira, ações genéricas de globalização, desregulamentações, etc.

Sabemos, por meio das lições sobre economia política de Marx, que as condições sob as quais um modelo de produção se dá tem repercussões nas outras dimensões sociais, sobretudo nas relações entre o capital e o trabalho, ou seja, em como a força de trabalho será absorvida pelos controladores dos meios de produção. Assim,

Sob este aspecto, está em curso nos países desenvolvidos uma tendência à desregulação e à flexibilidade em termos de contratação e uso da mão de obra. Ela se expressa na variação do nível de emprego e das horas trabalhadas; na polivalência, permitindo atribuir ao trabalhador várias funções e, ainda, na modificação da estrutura de salários e de remuneração. (CARVALHO, 2003, p.36) 
Este quadro, muito mais presente nos países onde foram geradas e aplicadas estas inovações, agrava ainda mais o problema do desemprego nos países que possuem uma industrialização intermediária combinada a uma grande desigualdade econômica e social, como o Brasil, no momento em que se adequa a nova ordem econômica mundial sem levar em conta o agravamento dos problemas socioeconômicos existentes.

Dentre estes, estamos vivenciando o aprofundamento da miséria da classe trabalhadora de modo inversamente proporcional à acumulação de riqueza de posse da burguesia. Todavia, tais transformações surgem da concorrência intercapitalista em busca da conquista de mercados e, conseqüentemente, da necessidade do aumento da produtividade e da competitividade.

Na esteira desse processo de acumulação de capital, ocorre uma redução do valor das mercadorias, levando a uma diminuição considerável da taxa global de produção de mais-valia. Isto significa dizer que, em virtude do considerável desenvolvimento das forças produtivas decorrente da concorrência intercapitalista -, o capital, de um modo geral, necessita de cada vez menos trabalho para produzir uma mesma quantidade de mercadorias. Entretanto, para o modo de produção capitalista não interessa a sobra de tempo que a sociedade ganha com o desenvolvimento das forças produtivas. A produtividade só importa ao capital quando aumenta o tempo de trabalho excedente da classe trabalhadora possibilitando ampliar a extração de maisvalia, permitindo assim, a acumulação e a reprodução do capital.

Conforme Sguissardi (2001, p. 102), “a expansão do capital na sociedade, em suas diversas atividades, produz uma tendência de saturação e uma consequente queda da taxa geral de lucros, obrigando o movimento de expansão a redirecionar-se para outros espaços nos quais a saturação ainda não se deu...". Na mesma direção, estamos constatando um "tendencial esgotamento, ou pelo menos, o questionamento do modelo clássico taylorista/fordista de organização da produção e a decorrente emergência de novos modelos" (TUMOLO, 1998, p. 19), dentre os quais um modelo de acumulação flexível de capital que se transforma “provavelmente, na maior referência do período recente". Tal modelo de acumulação flexível tem sido denominado sistema toyota de produção ${ }^{20}$; “que se converteu numa das principais

20

Segundo o autor do Toyotismo, o Sistema Toyota de Produção foi concebido e sua implementação começou logo após a Segunda Guerra Mundial; porém, passou a ser implantado na indústria japonesa na década de $70 \mathrm{com}$ a primeira crise do petróleo de 1973 (OHNO, 1997, p. 23, et seq.). Genericamente visa a redução de custos no processo produtivo, evitando os desperdícios da produção em "larga escala". Utiliza-se de uma progressiva inovação tecnológica articulada com novas formas de gestão e organização do trabalho, tendo como objetivo o aumento da produtividade e da competitividade. Nas palavras do criador do "just in time”, "o sistema toyota (...) não é apenas um sistema de produção (...); 
referências teórico-práticas" (TUMOLO, 1999, p.2) - difundida inclusive no setor de serviços do capital, tendo como objetivo aumento da produtividade e obtenção de maiores índices de lucratividade através da racionalização do processo de trabalho e da consequente intensificação da exploração sobre a força do trabalho, que se configura enquanto característica fundamental do novo padrão de acumulação de capital.

\section{2 - Os impactos da crise capitalista na educação superior}

Assim, as mudanças por que vem passando a Educação Superior no Brasil têm como pano de fundo "um movimento mais amplo de mudanças na economia (base produtiva) e na reconfiguração do Estado..." (SGUISSARDI, 2001, p. 19), o que "requer que se considere como pressuposto e como hipótese" que um processo de contra-reforma na Educação Superior "está se dando no contexto e como consequência (...) do movimento de passagem do regime de acumulação fordista para o denominado de acumulação flexível (...), [e] do movimento da propalada diminuição do Estado...”, levada a cabo pelas políticas neoliberais $^{21}$ (SGUISSARDI, 2001, p. 19).

Comecemos a análise sobre os impactos sofridos pela Educação Superior pela aprovação da LDB n 9394/1996. No tocante ao processo de elaboração da referida Lei, é possível concluir que embora tenha existido uma intensa mobilização dos atores sociais que militam nesse campo e, com isso, a construção de um documento comprometido com os interesses e necessidades da população brasileira, houve, inadvertidamente e intempestivamente, a interferência do governo FHC, dando a ela uma conotação conservadora. De acordo com Alves (2002), a lei aprovada é o cumprimento de um programa tornando-se um marco simbólico de uma guinada neoconservadora da educação no Brasil na década de 90, nos moldes do ideário neoliberal. Esse programa começou a ser implementado no Brasil de forma mais sistemática e incisiva no governo de Collor e de FHC.

A partir disso, é possível identificar os desdobramentos dessa lei na materialização das políticas públicas expressa em parâmetros da qualidade total e demais aspectos inerentes às

revela sua força como um sistema gerencial adaptado à era atual de mercados globais e de sistemas computadorizados de informação de alto nível” (OHNO, 1997, p. 23, et seq.).

${ }^{21}$ As políticas neoliberais se configuram na implementação de políticas pautadas num arcabouço ideológico-político de defesa de um Estado mínimo, ou seja, significa "o desmonte do Estado (...) na sua capacidade de financiar a educação e outros serviços, como a saúde..." "Na realidade a idéia de Estado mínimo significa o Estado máximo a serviço dos interesses do capital” (FRIGOTO, 1999, p. 59). 
exigências do processo de reestruturação produtiva e da política neoliberal implantada naquele governo, mediatizada pelos organismos financeiros internacionais. Segundo David,

\footnotetext{
"Desde a promulgação da nova LDB (1996), estão surgindo as reformas preconizadas sob a forma de parâmetros e diretrizes curriculares, demarcando oficialmente os caminhos a serem trilhados pela educação, para que atenda aos reclames da nova ordem econômica internacional e das necessidades da sociedade brasileira (2003, p. 5).
}

Ainda reitera que a implementação de modelos pedagógicos instrumentais e técnicos, as novas perspectivas da qualidade da educação pelo viés do pragmatismo de resultados e implementação de pressupostos baseados na competência técnica, coloca o processo de formação em estreita relação com o mercado e na direção contrária de uma formação de professores comprometida com a emancipação do sujeito histórico-social (DAVID, 2003).

$\mathrm{Na}$ esteira dos questionamentos em torno desse importante marco legal da educação, ainda é levantado o fato de que muito embora o governo da época a tenha proclamado como um avanço em torno da qualidade da educação, é possível constatar que não houve em proporções satisfatórias a alocação de recursos que permitissem, por exemplo, a valorização dos professores e investimentos na educação superior com a revitalização das estruturas físicas e abertura de novas universidades públicas, acontecendo completamente ao contrário. A categoria dos professores continuou desvalorizada e desrespeitada e a expansão da oferta de cursos se deu por meio da proliferação das IES privadas. Passemos então a analisar esse movimento da Reforma da Educação Superior, algo que vai modificar o cenário da formação profissional no Brasil.

\section{3 - Neoliberalismo e a Reforma da Educação Superior}

A década de 1990 foi, no Brasil, o período em que se efetivaram tentativas de submeter a necessidade de crescimento econômico do país às mudanças em curso no mundo, tidas por Silva Jr. (2003, p. 53) como “a universalização do capitalismo como marco nos anos 1970”. Nesse contexto,

... O governo brasileiro desenvolve um processo de reforma do Estado que encontra o ensino superior brasileiro como uma etapa, a partir de um conjunto de ações consentidas e realizadas pelas autoridades educacionais "(...) direcionadas por uma razão instrumental, que se constitui no epicentro de um processo de mercantilização do trabalho imaterial, em geral, e em particular, da esfera educacional em seu nível superior”. (SILVA JR. , 2003, p. 61) 
Analisando a interferência dos organismos internacionais nas políticas públicas para a Educação, em especial a Reforma da Educação Superior e a formação de professores, David (2003) identifica, a partir de documento do Banco Mundial, quatro orientações:

1. Fomentar a maior diferenciação das instituições, incluindo o desenvolvimento de instituições privadas;

2. Proporcionar incentivos para que as instituições diversifiquem as fontes de financiamento, por exemplo, a participação dos estudantes nos gastos e a estreita vinculação entre o financiamento fiscal e os resultados;

3. Redefinir a função do governo no ensino superior;

4. Adotar políticas destinadas a outorgar prioridade aos objetivos da qualidade e da equidade ( BM, 1994, apud DAVID, 2003, p.16)

Com relação à primeira orientação, o autor destaca seus desdobramento no Brasil em função do considerável aumento de escolas particulares nos diversos níveis de escolaridade, o crescimento de novas modalidades de ensino com destaque para a Educação à Distância e a implementação dos institutos superiores de educação, com predominância para o ensino privado.

A segunda se refere à cobrança de taxas para cursos de extensão e especialização administrada por Fundações no interior das universidades públicas e demais iniciativas de cunho privado estão diretamente ligadas à segunda orientação.

A terceira orientação do BM diz respeito à redefinição do papel do Estado no ensino superior, ou seja, a adoção de políticas públicas que permitam ampliar a participação da iniciativa privada em relação ao ensino superior.

E, por último a quarta orientação, que se refere à implementação de diretrizes curriculares que assegurem a qualidade total do ensino, a gestão gerencial e a racionalidade técnica com a formação ligada à noção de competências e avaliação institucional, que inclui a avaliação da produtividade e o desempenho dos docentes. Ao Estado restaria o papel de reduzir o financiamento e ampliar o poder de controle, credenciamento, fiscalização e avaliação dos cursos.

Atualizando o debate em torno das políticas públicas em relação à Educação Superior poderíamos observar que a lógica expansionista da educação superior privada adotada no governo FHC tem continuidade no governo Lula. Embora existam semelhanças entre as políticas públicas do governo Lula com as de FHC, é possível identificar também alguns distanciamentos. Autores como (GOMES, 2008; SANTOS, 2004; CORBUCCI, 2004) 
identificam que algumas medidas pontuais distinguem-se das iniciativas anteriores. Corbucci (2004) enfatiza que pelas diretrizes anunciadas e os procedimentos que foram adotados pelo governo Lula, a proposta de reforma desse governo distingue-se das iniciativas do governo FHC, “ao reconhecer que a democratização desse nível de ensino não se reduz à mera expansão da oferta de vagas e, ao mesmo tempo, ao atribuir à instituição universitária papel central no processo de desenvolvimento nacional” (CORBUCCI, 2004, p. 696).

Para Arruda in Arruda (2012, p. 87), a perspectiva de política de expansão da educação superior voltada para esfera pública pode ser caracterizada em três dimensões a saber:

I) Expansão para o Interior (2003/2006) cuja evidencia consiste na consolidação de duas universidades federais, criação de doze novas IFES e criação e consolidação de quarenta e nove campi universitários nas diversas regiões do país;

II) Expansão com Reestruturação (2007/2012), adesão da totalidade das IFES ao Programa Reuni, consolidação e implantação de 95 campi universitários e ampliação do número de vagas, especialmente no período noturno; e,

III) Expansão com ênfase na Integração Regional e Internacional (2008). Trata-se da criação da Universidade Federal da Integração LusoAfrobrasileira (Unilab), Universidade da Integração Latino-Americana (Unila) e Universidade Federal da Integração da Amazônia (Uniam). Acompanhando essas medidas foram lançadas outras estratégias envolvendo ações afirmativas como os programas para a população negra nas instituições federais e estaduais da educação (Uniafro), o Programa de Formação Superior e Licenciaturas Indígenas (Prolind) e o Programa de Acessibilidade.

É importante ressaltar também que por meio do Decreto n. ${ }^{\circ} 5.800 / 2006$, o MEC, em conjunto com o Fórum das Estatais pela Educação, criou o Sistema Universidade Aberta do Brasil (UAB), que busca por meio da modalidade de educação a distância, expandir e interiorizar a oferta de cursos e programas de educação superior no país (ARRUDA, 2012).

A partir desses dados, é possível inferir que embora exista uma íntima ligação entre as políticas públicas para a Educação Superior no Brasil com o modelo neoliberal/privatizante, que contribui para a mercantilização desse nível de ensino, a partir de 2002 esse quadro sofre alterações. Amplia-se a participação de setores populares que tencionam o governo a adotar programas e políticas que intensificam e ampliam a participação do Estado nesse setor. Esta forma de gestão é bastante contraditória e expõe os limites de um governo pretensamente popular no seio de um sistema marcadamente capitalista. A tentativa de conciliação de interesses de classes no governo Lula vai ser traduzida pelo caráter paradoxal das suas políticas. Ao mesmo tempo privatizante e em apoio à mercantilização da educação por meio do incentivo às instituições privadas (PROUNI, FIES, etc) e, por outro lado, a ampliação do acesso das 
classes mais baixas à Educação Superior, embora não se reconheça a qualidade da formação de todas elas.

\section{4 - As reformas curriculares dos cursos de graduação}

Ao analisarmos as transformações societárias ocorridas a partir de meados da década de 70 e no Brasil, de forma mais pronunciada nos anos 90, tivemos a oportunidade de não só identificar as mudanças no modo de produção capitalista, como também o papel do Estado na formulação de políticas públicas capazes de assegurar as condições ideais para o protagonismo do capital e seu consequente aumento dos lucros.

Vimos que, em sua gênese, a Reforma da Educação Superior baseou-se substancialmente nessa lógica, a de reduzir a presença do Estado no ensino superior abrindo, portanto, caminho para a iniciativa privada.

Percebemos, também, que esse quadro se atenua no governo Lula, exibindo políticas contraditórias em virtude da correlação de forças presente em sua gestão. Da lógica inerente à tese da conciliação de classes deriva políticas paradoxais caracterizadas ao mesmo tempo por avanços e retrocessos .

Nesse contexto, as diretrizes curriculares para a formação profissional passa ser o instrumento que dará materialidade aos preceitos e imposições do capital no processo de formação profissional. Embora reconheçamos a contraditoriedade das políticas públicas nos atuais tempos, como já abordado, é preciso reconhecer o imperativo do mercado na concepção e consecução desses documentos.

Se tomarmos os seus conceitos e princípios perceberemos que, pelo menos no texto, talvez em menor proporção no contexto formativo, em função de outras variáveis, o ideário concebido para a formação de profissionais das mais diversas áreas, seja licenciatura ou bacharelado, é a do profissional competente, que sabe operar com eficiência, criatividade, flexibilidade, compromisso e liderança em torno das situações-problemas ou dos problemas imediatos que lhes são apresentados na sua prática profissional cotidiana.

Assim, é importante também saber que a emergência do modelo de competência se dá pela necessidade de superação de dois grandes modelos historicamente dominantes: o modelo da profissão, construído a partir das corporações artesanais urbanas, e o modelo do posto de trabalho, implantado de maneira extensiva sob a égide do taylorismo (ZARIFIAN, 2003). Nesse 
aspecto a lógica do "aprender a fazer" ${ }^{22}$ se traduz pela competência e pelo domínio ampliado das condições do trabalho e da produção.

No Brasil, essa mesma lógica servirá de base para a formação profissional e, por conseguinte, de inspiração para as Diretrizes curriculares. Assim, para David,

\begin{abstract}
A partir da promulgação da Lei de Diretrizes e Bases da Educação Nacional (Lei n. ${ }^{\circ} 9.394 / 96$ ), grande parte das propostas de políticas públicas para o setor educacional provenientes do governo federal, utiliza nos documentos e nos discursos oficiais o termo competências para designar um modelo de formação capaz de gerar eficiência e melhoria da qualidade da formação de recursos humanos, tanto para o mundo do trabalho quanto para o sistema educacional como um todo. O exemplo mais comum está expresso nas Diretrizes Curriculares Nacionais, para os diversos níveis de ensino do sistema educacional brasileiro, nas quais se ressalta a presença das noções de competências. No que tange ao projeto de formação inicial para professores da educação básica e a formação de profissionais liberais para atuarem no mercado de trabalho, o pressuposto das competências torna-se evidente e repetitivo em todos os documentos oficiais. (DAVID, 2003, p. 77)
\end{abstract}

Portanto, a ideia central e que dá sustentação ao projeto de diretrizes curriculares nacionais vincula-se diretamente ao projeto neoliberal para a sociedade brasileira, expresso na desincompatibilização do Estado, redução do seu tamanho e ação frente às demandas sociais, reformas estruturais e funcionais para o ensino superior e demais níveis de ensino além da elaboração de diretrizes curriculares centradas na lógica das competências.

Com efeito, a análise da formação nos cursos de licenciatura e Bacharelado a partir das novas diretrizes curriculares é preciso ser feita de maneira a compreender a sua contraditoriedade. É preciso considerar que, ao mesmo tempo em que atende aos anseios do capital, representa também avanços no plano curricular, sobretudo se comparado aos modelos curriculares anteriores. É com esse espírito que passaremos à frente, revisitando artigos publicados na década de 1990 em três importantes periódicos da área, tendo como objetivo analisar e categorizar a crítica ao processo de formação de professores de Educação Física a partir do modelo de 1983. Esperamos com isso, identificar os principais problemas relacionados ao processo formativo da área, para que possamos a partir desses dados, vislumbrar possibilidades de avanço no atual modelo de formação.

\footnotetext{
${ }^{22}$ Relatório da UNESCO, redigido por Jacques Delors e publicado em 1981, reunindo objetivos para Educação do Século XXI. Decorrente de estudos de educadores de várias partes do mundo, o relatório propõe, para a educação do século que iniciamos a trilhar, os seguintes objetivos: aprender a ser, aprender a fazer, aprender a viver juntos e a aprender a ser.
} 


\section{5 - O debate sobre a formação profissional em Educação Física que antecede a criação das novas diretrizes curriculares}

A segunda metade da década de 80 e primeira metade da década de 90 foram bastante significativas para a Educação Física por ser um período de intensa produção na área, sobretudo em torno da prática pedagógica. Uma década atrás, nos anos 80 , acompanhando o momento de abertura política e, portanto, fase em que a sociedade civil busca repudiar as posturas autoritárias e tecnocráticas da Ditadura Militar, a tônica no campo acadêmico da Educação Física será o de avaliar criticamente as práticas da Educação Física, especialmente aquelas vinculadas ao processo de alienação e legitimação do antigo governo.

Nesse sentido, na década de 90 temos a sistematização de publicações oriundas da década anterior que em sua maioria, denunciam o viés conservador da Educação Física, a partir do postulado cartesiano, consubstanciado na ideia do cultivo da saúde e do desempenho atlético por meio da ginástica e do esporte, além de apontar para novos paradigmas pedagógicos. Assim temos, nesse período, a "Metodologia do Ensino da Educação Física" do Coletivo de Autores, “Visão Didática da Educação Física” de autoria de professores da UFPE e da UFSM, “Concepções Abertas no Ensino da Educação Física” do alemão Heiner Hildebrant em parceria com a Celli Taffarel, “ O saber e o fazer pedagógicos” de Marcílio Souza Junior e "Entre a Educação Física na escola e a Educação Física da escola: a Educação Física como componente curricular" de Francisco Caparróz, entre outros que tratam dos aspectos teórico-metodológicos da Educação Física.

A busca por referências a uma prática progressista capaz de contribuir para a formação humana e crítica dos alunos, impõe aos pesquisadores a necessidade de refletir sobre novas propostas curriculares, tanto da Educação Física Escolar como do currículo de formação de professores. Portanto, a produção sobre essa temática nesse período, reivindica currículos e abordagens pedagógicas no ensino superior que permitam contribuir com a formação de professores comprometidos com a construção de valores e atitudes democráticas, além de um senso crítico voltado para a transformação social. Além do aspecto político-pedagógico da formação, outros debates surgem no período, trazendo importantes contribuições da teoria curricular. Por outro lado, no mesmo período, temos também o movimento das políticas públicas oficiais de índole neoliberal que vão impactar decisivamente esse debate. Esse antagonismo de interesses foi analisado pelo professor Nivaldo David da seguinte forma: 
Coexistem, portanto, duas realidades e distintos mundos que se entrecruzam e se distanciam, construindo a realidade, o mundo real - vivido e determinado pelas relações das pessoas que o compõem e o mundo oficial, normatizador das regras produzidas por uma elite, a serem seguidas pelo mundo real, a serviço da ideologia capitalista e do modo de pensar neoliberal do aparelho de Estado (DAVID, 2003, p. 20).

Nesse sentido, interessados em captar as nuances desse processo de construção da formação profissional em Educação Física, adotamos como estratégia analisar os artigos relacionados com o tema em três revistas científicas da área, com o objetivo de identificar os problemas mais recorrentes em torno da formação profissional e as principais reivindicações e sugestões dos autores em termos de novas proposições e ideias para o currículo de formação nesse período.

As revistas escolhidas foram as seguintes: Revista Brasileira de Ciências do Esporte (RBCE), Revista Movimento (UFRGS) e Revista Pensar a Prática (UFG). O critério de escolha dessas revistas foi: nível de importância para os profissionais da área, tempo de existência e acessíveis digitalmente na rede web. Os artigos foram selecionados a partir da sua vinculação com as seguintes palavras chaves: formação profissional, currículo, diretrizes curriculares da Educação Física, licenciatura e bacharelado. Foram selecionados para leitura apenas os artigos que se relacionavam diretamente com a discussão de currículo e formação vinculados a modelos curriculares da Educação Física.

Para esse tópico nos dedicaremos à análise e apresentação das questões referentes à formação profissional durante toda a década de 1990 estendendo a análise até o ano de 2001, ano que antecede a publicação das Diretrizes Curriculares para formação de professores. O nosso intuito é captar as críticas e as reivindicações relacionadas com o currículo de formação a partir do modelo curricular legalmente sustentado pela Resolução 03/87. Nesse percurso, esperamos reunir dados em torno dos problemas relacionados com a formação profissional derivados dessa normativa para, depois, compará-los ao modelo curricular atual. Nosso intuito é identificar se as críticas e proposições feitas pela comunidade científica e trabalhadores da Educação Física no período avaliado persistem ou se foram contempladas nas atuais diretrizes curriculares da Educação Física. Para tanto, apresentamos no quadro abaixo dados quantitativos sobre a produção no período aludido. 
Quadro IV: Produção de artigos sobre a formação profissional de 1990 a 2001

\begin{tabular}{|c|c|c|c|c|}
\hline $\begin{array}{c}\text { Ano de } \\
\text { publicação }\end{array}$ & RBCE & Revista Movimento & $\begin{array}{c}\text { Revista Pensar a } \\
\text { Prática }\end{array}$ & Total/Ano \\
\hline 1990 & 1 & & & 1 \\
\hline 1991 & & & & \\
\hline 1992 & 1 & & & 1 \\
\hline 1993 & 1 & & & 1 \\
\hline 1994 & & & & 1 \\
\hline 1995 & 2 & 1 & & 3 \\
\hline 1996 & & & 1 & 2 \\
\hline 1997 & 1998 & 1 & 1 & 1 \\
\hline 1999 & & & 1 & 6 \\
\hline 2000 & 2001 & 2 & 4 & Total geral \\
\hline $\begin{array}{c}\text { Total por } \\
\text { Revista }\end{array}$ & 10 & & & 16 \\
\hline
\end{tabular}

Fonte: Próprio autor

A partir desse levantamento, pode-se perceber que a produção de artigos na década de 1990 sobre a formação profissional é bastante incipiente. Isso se justifica pelo fato do currículo aprovado em 1987 ter sido implementado em 1990, surtindo seus primeiros efeitos somente a partir de 1993/4. Estudos sobre os impactos das novas diretrizes na formação só iniciaram em 1994, começando a ser difundidos a partir da segunda metade daquela década. No ano 2001 essa produção aumenta significativamente quando comparado ao total das publicações. Para ilustrar isso, de um total de 16 artigos, até 1997, foram publicados apenas 04 artigos contra 12 até 2001. Para nós, o interesse dos pesquisadores sobre a temática aumenta à medida que são implementadas as Reformas na Educação Superior e potencializadas no ano de 2001 em virtude do movimento de reforma curricular nos cursos de graduação. No ano de 2001 tivemos, em decorrência desse processo, um número exclusivo da RBCE (CBCE), com a temática formação profissional, identificado também por pesquisadores do NUTESES/UFU (2005) em trabalho parecido.

É importante destacar também que, nesse período, a Revista Brasileira de Ciências do Esporte foi o espaço de maior difusão cientifica sobre a temática em tela. Dos 16 artigos relacionados nesse estudo, 10 foram publicados na RBCE, acompanhados por 04 na Revista Pensar a Prática e 02 na Revista Movimento. Além das publicações na RBCE, o referido GTT organizou em 2005 uma coletânea de trabalhos exclusivamente sobre formação que vem contribuindo significativamente para a discussão sobre a temática e, também, com o desenvolvimento desse trabalho. 
Com relação ao foco principal deste subtítulo, isto é, captar as principais discussões/proposições sobre a formação profissional no período que antecede o processo de elaboração das atuais diretrizes curriculares da Educação Física implementadas a partir de 2001, selecionamos para análise apenas os artigos que antecederam esse período e que se referiam diretamente à formação do profissional em Educação Física, ainda normatizados pela Resolução CFE nº 03/87.

Nesse sentido, de um total de 16 artigos encontrados no período objeto de análise, utilizamos apenas 13 artigos. Desse total de artigos estudados, 09 foram publicados da RBCE, 02 na Revista Movimento e 02 na Revista Pensar a Prática. Como procedimento de análise, os artigos foram lidos integralmente sendo extraídos e interpretados os dados referentes às seguintes categorias adaptadas a partir do estudo desenvolvido por Costa et. ali.(2005): Ano, Autor, Instituição de vinculação; Temática; Problemas Abordados e Proposições. Para uma melhor visualização da análise por parte dos leitores, condensamos e distribuímos os dados nos quadros seguintes:

\section{Quadro V : Produção relacionada com a formação profissional naRevista Brasileira de Ciências do Esporte}

\begin{tabular}{|c|c|c|c|c|c|}
\hline Ano & Autor(es) & Instituição & Temática & Problemas abordados & Proposições \\
\hline 1990 & $\begin{array}{l}\text { João Batista } \\
\text { Andreotti } \\
\text { Gomes Tojal } \\
\text { Mantovani, } \\
\text { Demósthenes/ } \\
\text { Celi Taffarel }\end{array}$ & UNICAMP & $\begin{array}{l}\text { A formação nos cursos de } \\
\text { Educação Física face ao } \\
\text { mercado de trabalho". } \\
\text { “ Formação acadêmica para } \\
\text { atuação profissional no campo } \\
\text { de trabalho de Educação Física } \\
\text { em São Luis/MA }\end{array}$ & $\begin{array}{l}\text { Preparação mais aprofundada } \\
\text { para atender mercado de } \\
\text { trabalho. } \\
\text { Contradição no processo de } \\
\text { formação priorizando } \\
\text { aspectos técnicos ao invés de } \\
\text { uma base crítica conforme se } \\
\text { anuncia nos objetivos }\end{array}$ & $\begin{array}{l}\text { Currículo que ofereça um } \\
\text { conhecimento mais sólido } \\
\text { para atuar nos campos } \\
\text { emergentes da Educação } \\
\text { Física. } \\
\text { Currículo e prática voltados } \\
\text { para a formação crítica. }\end{array}$ \\
\hline 1993 & $\begin{array}{l}\text { Maria Cecília } \\
\text { de Miranda } \\
\text { Mocker }\end{array}$ & UFSC & $\begin{array}{l}\text { Currículo e } \quad \text { formação } \\
\text { profissional em } \quad \text { Educação } \\
\text { Física: algumas reflexões }\end{array}$ & $\begin{array}{l}\text { Currículo acrítico com base } \\
\text { nas ciências biológicas e } \\
\text { psicológicas; }\end{array}$ & $\begin{array}{l}\text { Currículo e prática voltados } \\
\text { para a formação crítica } \\
\text { Reivindica potencial } \\
\text { emancipatório na formação }\end{array}$ \\
\hline 1995 & $\begin{array}{l}\text { Amauri } \\
\text { Bássoli }\end{array}$ & $\begin{array}{l}\text { Universidade de } \\
\text { Maringá }\end{array}$ & $\begin{array}{l}\text { A formação universitária em } \\
\text { Educação Física }\end{array}$ & $\begin{array}{l}\text { Falta de competência dos } \\
\text { professores para lidar com as } \\
\text { questões do ensino no } \\
\text { currículo; } \\
\text { Ausência } \\
\text { interdisciplinaridade; } \\
\begin{array}{l}\text { Falta de compromisso do } \\
\text { aluno com o curso }\end{array} \\
\end{array}$ & $\begin{array}{l}\text { Currículo e prática voltados } \\
\text { para a formação crítica }\end{array}$ \\
\hline 1998 & $\begin{array}{l}\text { Comissão de } \\
\text { Especialista } \\
\text { em Educação } \\
\text { Física } \\
\\
\text { Vicente } \\
\text { Molina Neto }\end{array}$ & UFRGS & $\begin{array}{l}\text { Novas Diretrizes para os Cursos } \\
\text { de Graduação em Educação } \\
\text { Física: Justificativas, } \\
\text { Proposições e Argumentações } \\
\text { A formação profissional em } \\
\text { Educação Física e Esportes }\end{array}$ & 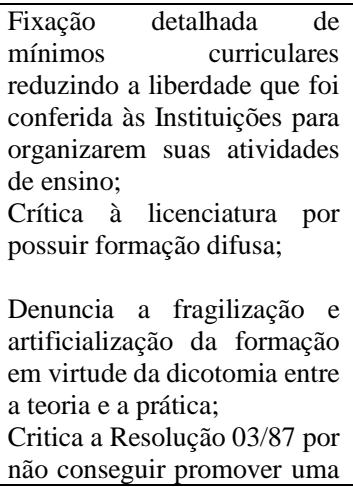 & $\begin{array}{l}\text { Criação do bacharelado com } \\
\text { formação generalista; } \\
\text { Licenciatura } \\
\text { especialização escolar } \\
\text { Forjar no aluno, ao longo do } \\
\text { processo formativo, uma } \\
\text { consciência investigativa da } \\
\text { sua prática; } \\
\text { Cultura reflexiva que possa } \\
\text { determinar a reinvenção da }\end{array}$ \\
\hline
\end{tabular}




\begin{tabular}{|c|c|c|c|c|c|}
\hline & & & & $\begin{array}{l}\text { formação que ofereça } \\
\text { condições para os professores } \\
\text { atuarem melhor nas escolas } \\
\text { de } 1^{\circ} \text { e } 2^{\circ} \text { graus. } \\
\text { Critica a fragmentação e a } \\
\text { progressão dos conteúdos no } \\
\text { currículo; }\end{array}$ & $\begin{array}{l}\text { prática pedagógica e também } \\
\text { da cultura esportiva. }\end{array}$ \\
\hline 2001 & $\begin{array}{l}\text { Leda Sheibe e } \\
\text { Vera Lucia } \\
\text { Bazzo } \\
\\
\text { Anna Maria } \\
\text { Salgueiro } \\
\text { Caldeira } \\
\end{array}$ & (1) & $\begin{array}{l}\text { Políticas governamentais para a } \\
\text { formação de professores na } \\
\text { atualidade } \\
\text { Formação de professores de } \\
\text { Educação Física: quais saberes, } \\
\text { quais habilidades? } \\
\text { Ensino reflexivo em uma } \\
\text { experiência no ensino superior } \\
\text { em Educação Física }\end{array}$ & 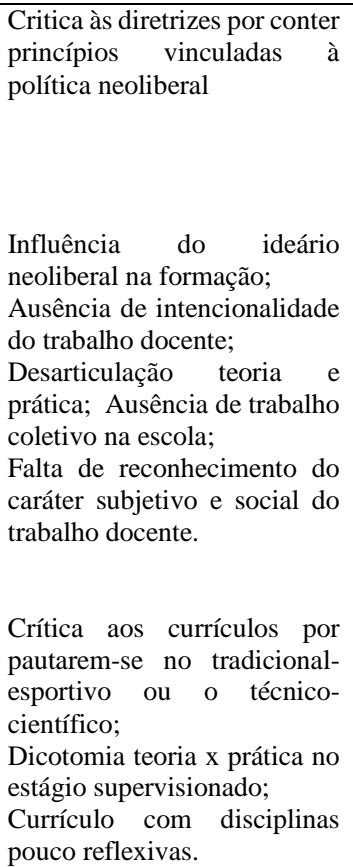 & 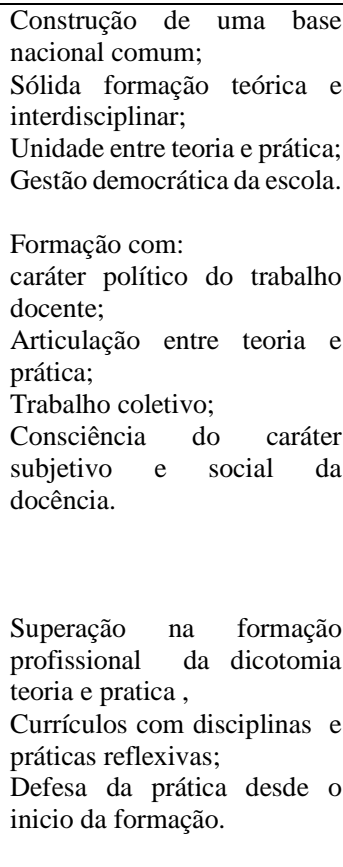 \\
\hline
\end{tabular}

Fonte: Revistas RBCE

\section{Quadro VI : Produção relacionada com a formação profissional na Revista Movimento}

\begin{tabular}{|c|c|c|c|c|c|}
\hline Ano & Autor(es) & Instituição & Temática & Problemas abordados & Proposições \\
\hline 1997 & $\begin{array}{l}\text { Celi Nelza } \\
\text { Zulke } \\
\text { Taffarel }\end{array}$ & UFPE & 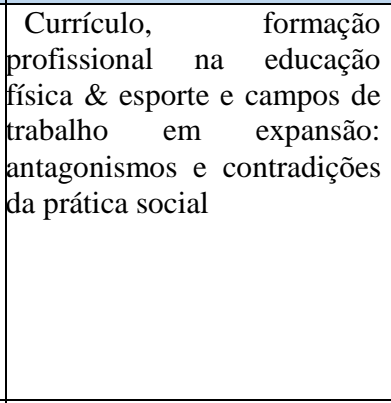 & $\begin{array}{l}\text { Currículos de formação } \\
\text { profissional em Educação } \\
\text { Física intimamente ligados } \\
\text { aos interesses do capital; } \\
\text { Crítica aos currículos } \\
\text { ordenados pela Resolução } \\
03 / 87 \text { por atenderem aos } \\
\text { interesses do mercado de } \\
\text { trabalho ao invés de } \\
\text { proporcionarem uma } \\
\text { formação humana e crítica. }\end{array}$ & $\begin{array}{l}\text { Reformular os } \\
\text { currículos visando a } \\
\text { adequá-los à uma prática } \\
\text { pedagógica } \\
\text { comprometida com a } \\
\text { transformação social }\end{array}$ \\
\hline 1999 & $\begin{array}{l}\text { Vera Brauner } \\
\text { e Flávio } \\
\text { Miiller }\end{array}$ & UFRGS & $\begin{array}{l}\text { Professor José: vivências e } \\
\text { reflexões } \\
\text { robre uma } \\
\text { formação em } \\
\text { Física }\end{array}$ & $\begin{array}{l}\text { Ausência do conhecimento } \\
\text { da realidade do mercado de } \\
\text { trabalho; } \\
\text { Ausência de experiências } \\
\text { práticas de docência; } \\
\text { Ensino artificializado }\end{array}$ & $\begin{array}{l}\text { Rompimento da } \\
\text { dicotomia teoria } x \\
\text { prática na formação; } \\
\text { Ampliação das } \\
\text { experiencias em relação } \\
\text { aos espaços de atuação } \\
\text { profissional. }\end{array}$ \\
\hline
\end{tabular}


Quadro VII : Produção relacionada com a formação profissional naRevista Pensar a Prática

\begin{tabular}{|c|c|c|c|c|c|}
\hline Ano & Autor(es) & Instituição & Temática & Problemas abordados & Proposições \\
\hline 1998 & $\begin{array}{l}\text { Anegleyce } \\
\text { Teodoro } \\
\text { Rodrigues }\end{array}$ & UFG & $\begin{array}{l}\text { A questão da formação de } \\
\text { professores de Educação } \\
\text { Física e a concepção de } \\
\text { professor enquanto intelectual } \\
\text { - reflexivo - transformador }\end{array}$ & $\begin{array}{l}\text { Formação acrítica, tecnicista } \\
\text { e instrumentalizadora; } \\
\text { Dicotomia entre teoria e } \\
\text { prática }\end{array}$ & $\begin{array}{l}\text { Currículos que permitam a } \\
\text { reflexão na ação; } \\
\text { Formação que abranja o } \\
\text { conhecimento das } \\
\text { limitações sociais, } \\
\text { culturais e ideológicas da } \\
\text { própria profissão docente. }\end{array}$ \\
\hline 1999 & $\begin{array}{l}\text { Comissão } \\
\text { Estudos } \\
\text { Curriculares }\end{array}$ & FEF/UFG & $\begin{array}{l}\text { Reforma do ensino superior: } \\
\text { diretrizes curriculares em } \\
\text { Educação Física - ponto de } \\
\text { vista da comissão de estudos } \\
\text { curriculares da fef/ufg }\end{array}$ & $\begin{array}{l}\text { Crítica à proposta de diretriz } \\
\text { curricular para a Educação } \\
\text { Física apresentada pela } \\
\text { Comissão de Especialistas } \\
\text { do MEC: } \\
\text { Modelo técnico e } \\
\text { cientificista; } \\
\text { Falta de diálogo com as } \\
\text { áreas sociais do } \\
\text { conhecimento; } \\
\text { Critica a concepção de } \\
\text { conhecimento fragmentado } \\
\text { divido em etapas, com } \\
\text { caráter de terminalidade e } \\
\text { linear. }\end{array}$ & $\begin{array}{l}\text { O projeto curricular deve } \\
\text { possibilitar: contextualizar } \\
\text { histórica, política, } \\
\text { econômica e socialmente a } \\
\text { prática docente; apropriar- } \\
\text { se dos processos de } \\
\text { sistematização, } \\
\text { organização e produção } \\
\text { dos saberes pedagógicos } \\
\text { oriundos da realidade } \\
\text { objetiva e seus problemas; } \\
\text { instrumentalizar a partir } \\
\text { de metodologias } \\
\text { interdisciplinares que } \\
\text { promovam e fortaleçam a } \\
\text { relação teoria e prática. }\end{array}$ \\
\hline
\end{tabular}

Fonte: Revistas Pensar a Prática

Pelos dados apresentados e a partir dos critérios estabelecidos para o estudo, é possível concluir que, do ponto de vista do espaço onde foram desenvolvidos estudos sobre a formação profissional no período em foco, 1990 a 2001, chegamos ao seguinte resultado: as Universidades UFSC, UFG e UFRGS aparecem em destaque com dois artigos cada, tendo em seguida as universidades UNICAMP, UFMA, Universidade de Maringá, PUC- Minas, UNESP e UFPE com um artigo cada. Tivemos também um artigo publicado por um coletivo que compunham uma Comissão de Especialistas do MEC/CNE.

Do ponto de vista temático, os artigos abordam em geral as questões relacionadas com o currículo e a formação profissional. Assim, identificamos as seguintes categorias com seu respectivo número de ocorrência no estudo: Formação profissional em Educação Física e mercado de trabalho (4 artigos); Currículo e formação profissional (4 artigos); Diretrizes Curriculares para a formação de professores (3 artigos) e Experiências docentes na formação de professores ( 2 artigos).

Em continuidade, apresentamos sumariamente, as categorias relacionadas com os problemas na formação profissional que, na opinião dos autores, se constituíam em obstáculos para uma formação de qualidade. É importante observar que a apresentação das categorias relacionadas aos problemas da formação não atende, nesse momento, a critérios pré- 
estabelecidos. Procura-se apenas apresentar um extrato das dificuldades enfrentadas e detectadas pelos estudiosos da época para posteriores análises.

1- Formação difusa e inconsistente no nível da licenciatura;

2- Formação essencialmente técnica com base nas ciências biológicas e psicológicas;

3- Professores desqualificados para lidar com os aspectos pedagógicos no currículo;

4- Currículo disciplinar, fragmentado e linear;

5- Dicotomia entre a teoria e a prática na apreensão do conhecimento da Educação Física e no estágio supervisionado;

6- Formação inconsistente para atuar na Educação Básica;

7- Falta de interdisciplinaridade e do trabalho coletivo nos espaços de formação profissional;

8- Ausência de reflexão no processo de formação;

9- Currículo a partir da Resolução 03/87 voltado para o atendimento dos interesses do mercado emergente da Educação Física;

10- Desconhecimento da realidade docente durante a formação profissional;

11- Ausência de experiências práticas em relação à docência;

12- Ensino artificializado;

13- Vinculação dos currículos dos cursos de Educação Física ao projeto neoliberal.

Podemos constatar pela extensa relação de problemas que, embora o modelo curricular de 1987 seja considerado por muitos estudiosos da área como o mais avançado até o momento, não vivíamos no melhor dos mundos quando o assunto era formação profissional. A abolição do currículo mínimo e a autonomia das IES em relação à elaboração curricular, talvez tenham sido as principais virtudes dessa perspectiva curricular para a formação em Educação Física.

Passemos então a analisar as problemáticas citadas a partir dos seus autores, apresentando também, as suas proposições em termos curriculares e da formação profissional. Iniciemos pelo primeiro ponto, Formação difusa e inconsistente no nível da licenciatura. Dois artigos apresentam essa problemática como limite para o avanço no processo de qualificação profissional a partir da Resolução CFE nº 03/87.

O professor João Batista Andreotti Gomes Tojal (1990) vem discorrer sobre a necessidade de revisar os currículos de licenciatura de modo a permitir a formação de um profissional mais qualificado para o mercado de trabalho. Segundo ele, havia um crescimento e diversificação do mercado de trabalho da Educação Física não acompanhado pela formação profissional que, majoritariamente, formava para a estrutura educacional de $1^{\circ}$ e $2^{\circ}$ graus. Nesse 
sentido, a formação com base nas disciplinas pedagógicas e esportivas dificultava a apreensão por parte dos futuros egressos dos conhecimentos necessários para atuar no mercado emergente da Educação Física.

Com argumento parecido, os membros da COESP/MEC(1998), também reconheceram uma formação difusa nas licenciaturas em Educação Física gestadas por meio Resolução CFE $03 / 87$.

\begin{abstract}
...A comissão de Especialistas de Ensino da Educação Física analisou que, com o tempo, e a diversificação do mercado de trabalho em relação à Educação Física, os cursos de Licenciatura Plena, originalmente concebidos para propiciar uma formação consistente para atuar na escola foram incorporando disciplinas tanto de fundamentação teórica como disciplinas instrumentais para atender ao crescimento do mercado. Com isso, a formação se tornou difusa em virtude de não desenvolver as competências necessárias para qualificar a intervenção do professor em sua área de atuação profissional (COESP/MEC, 1998, p.37-47)
\end{abstract}

Em ambas as situações, o argumento da formação difusa serve como justificativa para a divisão da formação profissional tanto na escola como fora dela. É bom que se diga que a divisão da formação a partir da Resolução CFE nº 03/87 previa um bacharelado pautado na formação do pesquisador e o licenciado como "dador de aulas". No Parecer 138/02, a licenciatura não era específica para a Educação Escolar e o Bacharelado era voltado para a formação do profissional liberal não ligado à docência. Esses pressuposto serve de orientação para a primeira proposta de diretriz curricular da Educação Física elaborada pela COESP/MEC no nível do bacharelado, inviabilizada mais tarde pela Diretriz de Formação de Professores, Resolução CNE/CP no 01 e 02/2002.

Em continuidade analisaremos com maior rigor mais três pontos: Formação essencialmente técnica com base nas ciências biológicas e psicológicas; Currículo a partir da Resolução CFE 03/87 voltado para o atendimento dos interesses do mercado emergente da Educação Física e formação inconsistente para atuar na Educação Básica.

Para Mantovani apud Taffarel(1990), em trabalho feito com egressos do Curso de Educação Física da UFMA, embora o perfil profissional do curso apontasse para a formação de professores críticos, capazes de transformar a realidade em que iriam atuar, na prática vinha se dando o contrário, os egressos e, portanto, profissionais formados pela instituição, vinham se mostrando acríticos, tecnicistas e a-históricos. 
Mocker(1993) nesse sentido, faz um comparativo entre duas teorias alocando conceitos tradicionais de matriz epistemológica biológica e psicológica de um lado e do outro conceitos mais críticos fundados numa matriz histórico-crítica. Para essa autora, visões de currículos fundadas em diferentes bases epistemológicas convivem na formação de professores de Educação Física, com predominância para o modelo das ciências biológicas.

Para Molina (1998), os planos de ensino de diversas disciplinas mostram que os alunos aprendem um conjunto de técnicas e sequências pedagógicas que promovem a iniciação esportiva de maneira eficaz, reforçando a perspectiva técnica na formação. Dessa forma, "muitas destas disciplinas apresentam em seus objetivos e avaliação, exigências de desempenho físico e atitudes que caracterizam uma forma higiênica e estóica de pensar a formação e o trabalho dos professores de Educação Física” (p.34-40).

Justificando a inconsistência da formação de professores para atuar na Educação Básica, observa também que “... embora o currículo tenha aumentado a sua carga horária para $2880 \mathrm{~h}$ e tenha existido uma redução nas disciplinas de técnicas corporais em favor do conhecimento biológico e pedagógico, não consegue promover uma formação que ofereça condições para os professores atuarem melhor na Educação Básica (idem, p. 34-40).

Por último, ao se referir à subsunção do currículo de formação ao mercado de trabalho emergente da Educação Física, avalia que o grande número de disciplinas no currículo manteve o enfoque enciclopédico e a perspectiva técnica na formação de professores. Completa, afirmando que “... a inclusão de novas disciplinas vinculadas às práticas esportivas emergentes evidencia a forte subordinação do curriculum aos interesses impacientes do mercado de trabalho." (MOLINA, 1998).

Tecendo críticas substanciais aos currículos orientados por uma formação técnica, a professora Anegleyce Rodrigues da UFG avalia em seu artigo publicado na Revista Pensar a Prática no ano de 1998 que,

Exercer a atividade docente, ou seja, "dar aulas" não se resume a uma atividade técnica. $\mathrm{O}$ ato de ensinar não é o mesmo que aplicar métodos $\mathrm{e}$ técnicas, ou ainda copiar a receita do bolo na resolução de um problema qualquer que possa surgir nas diversas situações de aula. A dificuldade maior não é encontrar a resposta do problema e sim identificar o problema ou as situações problemáticas. (1998, p. 48-58)

Baseado nesses estudos, conclui-se que os currículos devam ser organizados de modo a possibilitarem o desenvolvimento do senso crítico e a emancipação dos alunos com vistas a transformação social. Além disso, é fundamental a compreensão de que os problemas 
pedagógicos afetos à Educação Física estão relacionados com uma dinâmica social mais ampla, sendo portanto essencial a contextualização social, política, econômica e histórica dos fatos sociais e dos dilemas profissionais.

Bássoli (1995), ao analisar o processo de reformulação curricular desencadeado pela Resolução 03/87, aborda, além de outros problemas, que os professores estão desqualificados para lidar com os aspectos pedagógicos no currículo. Assim,

Com relação à competência para o desenvolvimento da nova estrutura curricular, assinala que a maioria dos docentes não estão preparados para atuar efetivamente com essa nova perspectiva paradigmática em função do comodismo e do aprofundamento em torno das questões teóricas. O que houve foi uma disputa por espaço no currículo, ou seja, para assegurar o seu espaço de atuação no curso sem, porém, se preparar adequadamente para atuar na disciplina que lhe foi conferida (BÁSSOLI, 1995, p. 209-212).

Finaliza conclamando a todos para lutar pela efetivação de uma formação assentada sobre parâmetros críticos e comprometida com a transformação social.

Elucidando e melhor compreendendo os problemas listados pelos pesquisadores na década de 90, passaremos agora a analisar dois pontos que estão articulados entre si e que poderiam fazer parte da mesma categoria de problemas, embora tenham sido listados separadamente. São eles: Currículo disciplinar, fragmentado e linear; e Falta de interdisciplinaridade e do trabalho coletivo nos espaços de formação profissional.

Destacaremos alguns autores estudados no período selecionado para tentarmos esclarecer melhor essas duas problemáticas. Comecemos por Bássoli (1995) que ao analisar as perspectivas dos novos currículos dos cursos de Educação Física, observa que nessa nova estrutura curricular abre-se grandes possibilidades para a efetivação da interdisciplinaridade, muito embora, na prática, isso não venha ocorrendo em função das dificuldades de organização da prática pedagógica nos cursos de Educação Física e na Universidade Brasileira de um modo geral que ainda conserva os ranços do passado.

Para Caldeira (2001), o que tem predominado na prática dos professores na escola é o individualismo com que realizam as tarefas docentes. Assinala que "entre os fatores que explicam este comportamento, encontra-se o modelo de organização do trabalho escolar centrado nas relações: professor - disciplina, professor - turma e professor - aluno" (p 93). Segundo a autora, tal modelo dificulta a integração e a discussão dos professores em torno de problemas comuns no interior do espaço educativo. 
A discussão sobre a interdisciplinaridade e a falta de integração do coletivo da escola em torno de uma prática pedagógica comum, embora fosse difundida no período estudado, no nível da formação profissional e do currículo da Educação Física, havia poucas experiências consolidadas. Por isso, a ausência dela consubstanciava-se em um limite reconhecido para uma formação de qualidade, mas do ponto de vista da estrutura e execução curricular não se conhecia muitas experiências.

Outros problemas importantes identificados são: dicotomia entre a teoria e a prática na apreensão do conhecimento da Educação Física e no estágio supervisionado; desconhecimento da realidade docente durante a formação profissional; ausência de experiências práticas em relação à docência; e ensino artificializado. Em nossa opinião, esses quatro pontos articulamse entre si e toca num aspecto importante da formação que é a compreensão crítica e global do processo de intervenção pedagógica.

A esse respeito, Molina (1998) nos traz uma reflexão e uma ideia de currículo e de formação pautada na identificação do processo de formação inicial de professores com a prática docente da Educação Física. Segundo ele, a falta dessa sintonia entre o processo formativo e os problemas concretos da prática pedagógica provoca a fragilização e artificialização do ensino, ou seja, os conhecimentos transmitidos são esvaziados de significado, perdendo assim o seu valor no processo educativo do futuro professor.

Em estudo desenvolvido pelos professores Vera Brauner e Flávio Miller pela UFRGS, identificam a figura do "professor José" que relata as suas dificuldades no desenvolvimento da sua prática pedagógica. Segundo os autores, “a constatação de José é que a realidade do mercado de trabalho, em seu caso a escola, é completamente diferente da que lhe foi passada na universidade" ( BRAUNER e MILLER, 1999, p. 21-25). Aspectos como as condições físicas e matérias das escolas e a incapacidade para lidar com os problemas objetivos da prática pedagógica também são relatados pelo professor José como limites associados à realidade escolar que, em seu processo de formação, não teve a oportunidade de vivenciar e compreender (idem, 1999).

Ao destacar os princípios que fundamentam a formação docente, Caldeira (2001) inclui a articulação teoria e prática no currículo de formação profissional. Para a autora,

... a separação entre teoria e prática está presente em grande parte das propostas de formação inicial e continuada de professores. Quando se trata de formação inicial, critica-se a desvinculação entre os conteúdos da formação e a prática profissional na escola. De modo geral, a academia privilegia a teoria(conhecimento científico) em detrimento da prática(saber da experiência). Os programas de formação inicial costumam estar separados dos 
problemas reais que o professor deve enfrentar em seu trabalho cotidiano. Por exemplo: os alunos socialmente desfavorecidos e que, hoje, constituem a maioria dos alunos da escola pública são "desconhecidos" pelos docentes em formação. Assim, um dos desafios da formação inicial é trazer, para a reflexão nos cursos de licenciatura, a realidade escolar (Idem, 2001, p. 91).

Compreendendo a preocupação da autora em relação ao contato dos acadêmicos com a realidade prática, objetivado como espaço onde futuramente iriam atuar profissionalmente, é importante ressaltar que "prática" nada mais é do que a realidade. Por sua vez não há teoria que não seja a teoria de uma prática (teoria de um dado da realidade). se não for assim, não há teoria e sim "verborragia', discurso vazio.

Ainda destacando o problema do distanciamento da formação com a prática, reitera ainda que concebe o saber docente como um processo e não como algo estático, acabado e definitivo. Nesse sentido, a sua renovação deve estar constantemente penetrando a prática e vice-versa. A reavaliação crítica da prática docente, realizada de forma contínua, coletiva e pelo intercâmbio constante de conhecimentos e práticas torna-se uma condição essencial para o aperfeiçoamento do professorado em seu trabalho (Idem, 2001). Refletindo sobre o distanciamento da formação profissional em relação à prática docente, Rangel-Betti (2001), citando estudo anterior, relata que

... os currículos formam um aluno que apresenta uma certa insegurança no início da profissão, uma vez que a preparação para o magistério ocorre principalmente no último ano, na disciplina " Prática de ensino", que não parece ser suficiente para fornecer, sozinha, segurança na atuação pedagógica(BETTI e RANGEL-BETTI apud RANGEL-BETTI, 2001, p. 106).

Ainda para a autora, parte-se do princípio de que o aluno necessita ser inserido na prática de ensinar o mais cedo possível e, nesse sentido, citando Pérez-Gomes (1992, p. 110), que também construa e compare "novas estratégias de ação, novas fórmulas de pesquisa, novas teorias e categorias de compreensão, novos modos de enfrentar e definir os problemas”. Em sua opinião, esta possibilidade ofereceria ao futuro profissional condições de experimentar a prática sem, no entanto, sujeitá-lo às pressões que a prática verdadeira carrega (Idem, 2001).

Com isso Mizukami apud Rangel-Betti (2001) propõe que os currículos de licenciatura se estruturem de forma a não considerar teoria e prática de maneira dicotomizada, mas sim que façam o aluno, a partir da prática, refletir, discutir, analisar, questionar, criticar diferentes opções teóricas em confronto com esta mesma prática. Em outras palavras, a autora afirma que 
não propõe a volta da prática pela prática, como podem erroneamente supor alguns, mas um redirecionamento "teoria-prática-teoria” por meio da reflexão (idem, 2001).

Nesse sentido, esses estudos apontam para a busca de modelos curriculares e práticas docentes no interior das Universidades e dos cursos que rompam com a dicotomia teoria e prática e que aproximem definitivamente a formação profissional aos contextos e ambientes escolares em que se darão as intervenções pedagógicas. É importante ressaltar como limite na construção teórica supracitada, a ausência de nexos entre os problemas da prática pedagógica no interior das escolas com o contexto maior, ou seja, a realidade brasileira e mundial, dando uma conotação político-pedagógica à ação do professor.

Os estudos sobre o currículo e a formação profissional em Educação Física da época denunciam a "Ausência de reflexão no processo de formação" como um obstáculo à formação crítica dos professores. Assim, para Rodrigues (1998), uma nova concepção da prática profissional que deseja superar a relação linear e mecânica entre a dimensão científico-técnica do conhecimento da Educação Física e a prática na aula pode ser construída a partir dos conceitos de reflexão na ação, teoria, segundo a autora, de Donald Schon que trata da questão da reflexão como um componente complexo e importante da atividade do professor.

Nesse sentido, a formação de professores de Educação Física deve proporcionar situações que possibilitem a reflexão e a conscientização das limitações sociais, culturais e ideológicas da própria profissão docente.

Rangel-Betti e Galvão (2001) também denunciam a ausência de reflexão no processo formativo da Educação Física e, pautadas na teoria de Schon(1992), buscam aplicar por meio de uma experiência na educação superior a interface do ensino reflexivo que favorece ao aluno refletir antes, durante e após a prática de ensinar.

Isto posto, defendem a adoção de práticas reflexivas em todas as disciplinas ao longo do processo de formação profissional e, não somente na disciplina de prática de ensino quando é mais comum a reflexão em torno da prática pedagógica.

Muito embora as autoras defendam a adoção de práticas reflexivas na escola, é preciso ressaltar que nesse período, uma série de autores entre eles, Tardif (2000), Schon (1992), Perrenoud (2002) defenderam a formação do professor reflexivo, responsável em tese pelo movimento de reflexão na ação como algo inovador e crítico na educação. Sobre esse postulado é preciso compreender que os autores recriminam o saber escolar como sendo um saber estático e normativo imposto aos alunos. Em geral, apontam para a desvalorização do papel do conhecimento científico/teórico/acadêmico na formação do professor. A reflexão nesse sentido 
se dá em torno das situações cotidianas tendo como base para a análise o relativismo e o subjetivismo próprios das teorias pós-modernas.

Como última crítica identificada no processo de formação profissional temos a Vinculação dos currículos dos cursos de Educação Física ao projeto neoliberal. Essa questão é bastante emblemática para a nossa análise, pois, atualmente, pode ser encontrada como principal crítica, talvez única e definitiva, na maioria dos trabalhos publicados que se dispõem a analisar as diretrizes curriculares da Educação Física numa perspectiva ideopolítica.

Dessa forma, pela análise da produção nas revistas no período priorizado por esse trabalho, podemos perceber que a problemática da vinculação do processo formativo ao ideário neoliberal surge já na década de 1990, em relação ao modelo tipificado pela Resolução CFE nº $03 / 87$.

A primeira justificativa teórica que fortalece a ideia de que os currículos da Educação Física estão vinculados à lógica capitalista é dada pela professora Celi Taffarel em artigo publicado na Revista Movimento em 1997. A autora busca discutir o currículo e a formação profissional na Educação Física e Esportes a partir do entendimento de que no capitalismo o processo de formação dos profissional está condicionado aos interesses econômicos (TAFFAREL, 1997). Ressalta que,

O desafio a nós colocado, sob condições de absoluta e permanente regressão sócio-econômica, de massiva miséria popular, de crescente descontentamento social, é vincular o trabalho acadêmico - na formação e produção de conhecimentos, enquanto uma instância concreta de combate à dominação imperialista global. É não aceitar que o Projeto Neoliberal e a Pedagogia do Capital continue sendo o único parâmetro orientador de políticas públicas e de currículos. E, portanto, superar o caminho doutrinário e buscar a difícil articulação entre interesses imediatos e uma ação estratégica de clara conformação anticapitalista (TAFFAREL, 1997, p. 43 - 51)

É importante fazermos ponderações à assertiva da autora citada, uma vez que a formação, independente do modelo social, necessariamente atenderá às demandas do mundo real. É uma ilusão acharmos que iremos formar profissionais sem capacidade para atuar no mundo real do trabalho. Portanto, constatar que o processo de formação se dá condicionado à lógica econômica é uma redundância.

Molina (1998), ao discorrer sobre o processo de formação profissional, o faz a partir da análise da globalização e desenvolvimento da sociedade capitalista como sendo um revés social, na medida em que o capital acumulado não é distribuído e nem existem esforços para combater as desigualdades sociais. Opina que, ao contrário disso, são criadas novas estratégias de 
dominação e exploração da classe trabalhadora, refletidas na educação e na formação por meio das estratégias de profissionalização e capacitação profissional, além da precarização das condições de trabalho.

As críticas feitas aos currículos oriundos da Resolução CFE nº 03/87 em relação à sua orientação capitalista se dava pelo crescente aumento de disciplinas voltadas para o atendimento do mercado de trabalho emergente da Educação Física, conforme já aludido em outras análises nesse mesmo tópico. As denúncias que se seguem em torno da vinculação da formação profissional ao neoliberalismo ${ }^{23}$, terão como objeto de análise o projeto de novas diretrizes curriculares para a Educação Física.

Assim, em 1999, a Comissão de Estudos Curriculares da FEF/UFG, apresenta uma crítica à proposta de diretriz curricular apresentada pela Comissão de Especialistas do MEC, alegando que há uma oposição desta com os interesses do conjunto das Universidades Brasileiras, além de expressar as políticas atualmente impostas às universidades por meio dos organismos financeiros internacionais como FMI e BANCO MUNDIAL (CEC/FEF/UFG, 1999).

Para Caldeira (2001), a visão neoliberal referente à educação “... defende uma escola que se constitua em efetivo instrumento de controle social e se paute por qualidade e produtividade, características essas definidas com base no resultado educacional obtido e estabelecidas por meio de padrões, indicadores e medidas." (MOREIRA apud CALDEIRA, 2001, p. 88)

Para Scheibe (2001), as diretrizes curriculares em questão mostram seu vínculo com um determinado projeto societário que, conforme a visão de vários autores (FRIGOTTO, 2001; KUENZER, 2000; SHIROMA, 2000), em nome da globalização, ajusta as questões educacionais muito mais às regras da mercantilização, com toda exclusão que tal escolha produz, do que a processos efetivamente inclusivos.

Nesse sentido, sugere princípios a serem levados em conta no processo de formação como: Sólida formação teórica e interdisciplinar; Unidade entre teoria e prática; Gestão

\footnotetext{
${ }^{23}$ Para Galvão (2007), desde os anos 1980, o termo neoliberalismo vem sendo utilizado para se referir a um novo tipo de ação estatal, a uma nova configuração da economia, a um novo tipo de pensamento político e econômico, que guarda algumas relações com o liberalismo clássico, ao mesmo tempo em que apresenta certo número de inovações. Suas principais características são bem conhecidas. Dentre elas, destacam-se a privatização de empresas estatais, a desregulamentação dos mercados (de trabalho e financeiro), e a transferência de parcelas crescentes da prestação de serviços sociais - tais como saúde, educação e previdência social - para o setor privado. Essas medidas concretas contribuíram para difundir a tese do Estado mínimo e "enxuto", que teria entre suas metas uma política de "austeridade fiscal".
} 
democrática da escola, Compromisso social; Trabalho coletivo e interdisciplinar; e Integração da concepção de educação continuada (SHEIBE, 2001).

Para analisarmos as ponderações acima, será necessário retomarmos a discussão sobre a interpretação do método de análise da realidade em Marx, fonte inspiradora da maioria dos intelectuais que elaboram as críticas sobre as diretrizes curriculares. O argumento é que há uma intervenção daqueles que controlam os meios de produção sobre as políticas públicas de formação com o objetivo de forjar profissionais com competências e habilidades capazes de atender às demandas de um mercado cada vêz mais carente de versatilidade e criatividade. Se a tese for verdadeira,

“...o conhecimento da realidade não demandaria os sempre árduos esforços investigativos, substituídos pela simples "aplicação" do método de Marx, que haveria de "solucionar" todos os problemas: uma análise "econômica" da sociedade forneceria a "explicação" do sistema político, das formas culturais, etc" (NETTO, 2011, p. 13).

Além disso, seria necessário relativizar a tese de que a economia não deveria influenciar o processo de formação dos profissionais, afinal, há de se ter algum tipo de competência para atuar profissionalmente, seja uma sociedade capitalista ou socialista. Embora o processo de formação não seja um ato simplista, mecânico voltado apenas para o domínio de determinadas técnicas e habilidades, não precisa ser também um ato doutrinário em que se prepara o sujeito apenas para se contrapor ao sistema econômico e político onde vive. É preciso equilibrar as duas coisas e, sobretudo, compreender que os nossos alunos estão inseridos em uma sociedade capitalista. É precisamente nela que esses profissionais irão atuar. A defesa de uma sociedade mais justa supõe o conhecimento da estrutura em que o sujeito vive e se relaciona além dos conhecimentos e habilidades que facilitarão a sua inserção no mundo produtivo. Ademais, é importante ressaltar que a escola rica é a escola que ensina a cultura em sua plenitude. A formação da classe trabalhadora foi empobrecida e se diferencia da classe burguesa precisamente pela ausência dos conteúdos, do conhecimento da realidade em sua totalidade e também do conhecimento técnico. A educação contra-hegemônica talvez seja a que forneça ao sujeito as ferramentas que lhe permitam viver e transformar o mundo.

Finalizamos essa primeira etapa do estudo após termos listado e analisado as contribuições dos autores ao debate sobre o currículo e a formação profissional em Educação Física entre 1990 a 2001. As problemáticas aqui expostas serão, mais à frente, utilizadas como referência para identificarmos possíveis avanços ou retrocessos no atual marco normativo da 
formação em Educação Física. Para tanto, daremos continuidade às análises das publicações nos mesmos periódicos no período de 2002 a 2013.

\section{6 - Reflexões nada "aleatórias" sobre o processo de constituição histórica das diretrizes curriculares da Educação Física}

A tese de que a divisão da formação em licenciatura e bacharelado foi arquitetada pelo CONFEF juntamente com setores conservadores da Educação Física é aceita com um grau elevado de confiabilidade em nossa área em virtude do grande número de trabalhos publicados com essa versão. Uma espécie de maniqueísmo em torno desse fato histórico que, conforme narram, um grupo ficou em defesa dos trabalhadores da Educação Física repudiando qualquer possibilidade de acordo e, de outro, os "algozes conservadores" e "progressistas traidores" em conluio com o Estado e os capitalistas, num consenso escuso, decretaram a sentença de morte para a formação em Educação Física.

Resguardada as proporções, as ideias vinculadas por determinados autores têm contribuído apenas para cultivar antagonismos e certo preconceito às pessoas que acreditam haver possibilidades pedagógicas importantes e avanços consideráveis do ponto de vista curricular nas atuais diretrizes quando comparado aos modelos anteriores de formação profissional.

São muitos os trabalhos que reproduzem os mesmos fatos, em geral, citando os autores que participaram do processo de constituição histórica das atuais diretrizes. O que percebemos é que o argumento de quem condena as atuais diretrizes em virtude destas estarem associadas ao ditames do mercado de trabalho, invariavelmente, contam a história de modo que fique evidente a participação do CONFEF enquanto principal agente no processo de construção das diretrizes. A impressão é que a participação do CONFEF e dos setores conservadores da Educação Física é superestimada e dos representantes do CBCE e do Ministério do Esporte enquanto agentes ativos nesse episódio é subestimada. Mais a frente, detalharemos e contextualizaremos melhor a premissa que anunciamos nesse páragrafo.

Portanto, abriremos espaço para analisarmos a história desse acontecimento a partir de óticas diferentes, tanto dos setores progressistas da Educação Física que não admitiram participar do substitutivo final, parecer 058/03, quanto os setores progressistas vinculados ao CBCE e Ministério do Esporte. Para tanto, pesquisamos trabalhos acadêmicos dedicados à essa história, tendo nos ocupado das teses de Doutorado de Hajime Nozak (2004) e Paulo Ventura (2010) além de artigo das professoras Celi Taffarel e Solange Lacks (2005). Utilizamos também 
a fala do professor Lino Castellani Filho em debate com a professora Celi Taffarel na $64^{\mathrm{a}}$ Reunião Anual da SBPC em 2012. O intuito foi confrontar as histórias contadas de modo a identificar seus nexos e contradições na tentativa de acrescentar ao debate novos dados e novas formas de compreensão em relação a este importante fato histórico da nossa área.

O processo de construção das Diretrizes para a Educação Física foi disparado pela SESU/MEC logo depois do Parecer $776 / 97$ por meio do edital 04/97 publicado no D.O. em 12.12.1997, tornando pública a convocação para que todas as IES interessadas apresentassem propostas para a construção das novas diretrizes curriculares dos seus cursos superiores. No caso da Educação Física, foi feito o aprimoramento da Resolução 03/87 bem como a correção de algumas distorções constatadas ao longo dos doze anos de vigência segundo os membros da primeira COESP em publicação de artigo na RBCE (CEE/EF-MEC, 1998).

A justificativa da comissão para a criação do bacharelado se deu pela manifestação das IES de que a formação do licenciado não desenvolvia as competências e qualificações necessárias para a intervenção profissional nos diversos campos de trabalho não-escolar.

Destarte, as distorções mais polêmicas geradas no âmbito dessa discussão diziam respeito à interpretação do que seria o bacharelado: especialização/aprofundamento e/ou formação geral/básica e aplicada, bem como à interpretação dicotomizada da atuação profissional em função da dupla graduação: intervenção escolar (licenciatura) e/ou intervenção não escolar (bacharelado) (ANDRADE FILHO, 2001).

Fato concreto é que, embora esse modelo tenha gerado polêmicas e contrariado a comunidade acadêmica comprometida com uma formação mais humana e crítica, não pode vir a cabo em virtude da publicação do Parecer 009/2001 que estabeleceu Diretrizes Curriculares para a Formação de Professores da Educação Básica, em nível superior, Curso de Licenciatura de Graduação Plena, e o Parecer 021 /2001 que dispõe sobre a duração e carga horária dos cursos de Formação de Professores, mais tarde publicados sob a forma das Resoluções CNE/CP $\mathrm{n}^{\mathrm{o}}$ 01/02 e 02/02, diferenciando a licenciatura do bacharelado, estabelecendo terminalidade e integralidade própria a esses cursos.

Com isso, impôs-se a necessidade da criação de Diretrizes para os bacharelados e complementação das especificidades das licenciaturas. É importante ressaltar que

As diretrizes para as licenciaturas apontaram para que todas as áreas científicas que tivessem formação pelo bacharelado, se debruçassem para elaborar e aprovar as diretrizes para este modelo de formação, regulamentando as necessidades na formação de bacharéis e complementando as especificidades de suas licenciaturas, naquilo que não entrasse em colisão com as Resoluções para a formação de professores. Esclarecer isso se torna 
importante, na medida em que não se devam pensar as diretrizes curriculares específicas de cada área do conhecimento, como diretrizes exclusivas para 0 bacharelado. No entanto, criou-se uma representação, levando a que muitas áreas assim tenham procedido, o que acabou por promover as fragmentações desejadas pelo sistema dominante.(VENTURA, 2010, p. 144-145)

Nozaki (2004) analisa a ingerência do sistema CONFEF/CREF por meio do processo de articulação junto aos dirigentes, sobretudo de Instituições privadas, na realização de fóruns regionais e nacionais para discutir assuntos ligados à formação profissional. Além disso, visava formular documentos e textos que objetivassem contribuir com o processo de elaboração das diretrizes curriculares. Segundo ele, isso foi decisivo na elaboração do parecer 138/02.

Além da articulação desenvolvida pelo CONFEF/CREF junto aos dirigentes de IES privadas, Castellani Filho (2012) sustenta que o referido conselho mantinha uma relação junto à Câmara de Educação Superior, com o conselheiro escolhido para relatar o projeto das Diretrizes curriculares para a Educação Física, o conselheiro Carlos Serpa que, segundo o professor Lino, era carioca e professor de uma Universidade que o professor Jorge Steinhilber, então presidente do Conselho, mantinha laços bastante fortes. Baseado nisso, o CONFEF era então um interlocutor privilegiado junto àquele conselheiro na construção das Diretrizes e, foi justamente ele, que construiu o parecer 138 aprovado em 03 de abril de 2002.

Bastante criticado pela comunidade científica da Educação Física em virtude da sua relação visceral com a área da saúde, o referido parecer sofreu diversas interpelações. Entre elas, Taffarel e Lacks (2005) citam a acontecida na 54 Reunião Anual da Sociedade Brasileira para o Progresso da Ciência (SPBC), quando o Colégio Brasileiro de Ciências do Esporte (CBCE) consegue aprovar a deliberação de enviar carta ao presidente, ao vice-presidente da Câmara Superior do CNE/MEC e ao coordenador das diretrizes da área da saúde, solicitando a não aprovação do projeto de resolução que versava sobre as diretrizes da Educação Física e ao ministro da Educação, solicitando a revogação da homologação do Parecer 138/2002.

Também em evento organizado pelo CONFEF, durante o período de 15 a 18 do mês de julho de 2002 intitulado II Fórum de Diretores dos Cursos de Educação Física, foi articulado um documento para os mesmos destinatários da carta do CBCE, subscrito por, aproximadamente, 90 das cerca de 120 instituições presentes (TAFFAREL e LACKS, 2005).

Ainda segundo as autoras, o CNE "realizou reuniões nos dias 5 a 7 de agosto de 2002 e acolheu uma solicitação do Ministério do Esporte, decidindo não aprovar o projeto de resolução sobre as diretrizes propostas pelo CONFEF, dispondo-se, ainda, a reabrir as discussões sobre as diretrizes da Educação Física"(TAFFAREL e LAKS, 2005, p. 95). 
Por outro lado, Castellani Filho (2012), destacando a participação do CBCE na I Conferência sobre Educação , Cultura e Desporto, promovida pelo Congresso Nacional, Câmara Federal e Comissão de Educação, Cultura e Desporto observa que fizeram contatos com representantes do congresso e do CNE mostrando que a construção das diretrizes não vinha se dando de forma a envolver todos os segmentos do campo da Educação Física. Já na segunda Conferência em 2002, o CNE sinaliza para a abertura de uma nova rodada de negociações, tendo percebido que o processo anterior não havia contemplado todos os seguimentos da Educação Física, ou seja, o processo anterior havia ficado restrito ao Conselheiro Carlos Serpa e ao Conselho Federal de Educação Física (CONFEF).

Essas duas informações, a primeira das professoras e pesquisadoras Celi Taffarel e Solange Laks e a segunda do professor Lino Castellani Filho se apresentam contrastantes em virtude da primeira se referir ao acolhimento por parte do CNE de uma suposta solicitação do Ministério do Esporte, ainda não existente, porque no governo FHC em 2002. Ao contrário disso, a segunda informação revela o protagonismo do CBCE junto ao CNE, o que, portanto, nos faz entender que o CNE acolheu uma solicitação do CBCE e não do Ministério do Esporte, até porque, esse Ministério foi ser criado no governo Lula em 2003. Essa informação é importante, pois os mesmos agentes do CBCE que produziram a ação junto ao CNE em 2002, irão dar continuidade ao seu protagonismo no ano de 2003, só que dessa vez, à frente do Ministério do Esporte.

Segundo Castellani Filho (2012), o conselheiro Efrem Maranhão (coordenador das diretrizes da área da saúde/CNE) estabeleceu um tempo aos segmentos da Educação Física para que realizassem os debates e produzissem novas propostas. No mesmo ano, o CBCE promoveu em Campinas um evento com a finalidade de realizar novas discussões, em que foram convidados todos os segmentos da Educação Física, professores, entidades, dirigentes de cursos, CONFEF e movimento estudantil tendo, esse evento, servido de parâmetro para a elaboração de uma diretriz de formação profissional em Educação Física.

Nozaki (2004), Taffarel e Laks, (2005) e Ventura (2010) relatam que, embora o CNE tivesse suspendido a aprovação das diretrizes da Educação Física, com a mudança de governo, aconteceram pressões do CBCE, Ministério do Esporte e MEEF no sentido de interromper a tramitação do parecer 138/02.

À frente da Secretaria Nacional de Desenvolvimento do Esporte e do Lazer - SNDEL do Ministério do Esporte na época, o professor Lino Castellani Filho, narra esse episódio por ocasião de debate travado com a professora Celi Taffarel em mesa-redonda com o tema - 
Formação profissional em Educação Física: uma antítese que se arrasta... - Realizada na programação do CBCE na $64^{\mathrm{a}}$ Reunião Anual da SBPC no dia 25 de julho de $2012 .{ }^{24}$

“... Em 2003, já no Ministério do Esporte, numa tarde, o futuro Ministro Orlando, então Secretário Nacional de Esporte, me convida para fazer uma visita ao presidente do Conselho Nacional de Educação. Nessa oportunidade, aproveitei para perguntar ao presidente do Conselho, o que vinha sendo feito para ampliar a discussão a respeito do processo de elaboração das diretrizes curriculares da Educação Física. O presidente em consulta ao Efrem Maranhão, coordenador das diretrizes da área da saúde, solicitou que o seu secretário, verificasse a situação do parecer 138/02. A informação obtida foi que o relator, Carlos Serpa, estaria se aposentando no mês seguinte e que havia encaminhado o parecer sob a forma de Resolução para a Casa Civil da Presidência, com vistas à sua aprovação. Foi patente, a decepção e o constrangimento do conselheiro Efrem em torno da questão. De volta ao ministério, não me dando por vencido, ligo para a gráfica do Diário Oficial e solicito informações quanto à publicação do referido documento. Em resposta, fui informado que o documento se encontrava por ali e que ainda levaria alguns dias para ser publicado. Perguntei se existiria a possibilidade do mesmo ser retirado, tendo tido resposta de que seria possível a retirada, desde que o órgão que havia solicitado a publicação requeresse o contrário. Diante da informação, liguei para a secretaria do Conselho Nacional de Educação, transmitindo a informação da gráfica e solicitando, portanto, a retirada do documento. Passado alguns dias, ainda incrédulo de que o Conselho fosse de fato retirar o documento em virtude da preservação de seus conselheiros, recebo a ligação do referido órgão, informando-me que a resolução ali se encontrava. Com isso, foi retirado da gráfica o parecer 138/02 e a aprovação de uma possível resolução nesses mesmos termos" (CASTELLANI FILHO, 2012).

Portanto, acrescentamos mais essa informação àquelas, invariavelmente vistas nas publicações que se dispõem a narrar esse episódio sendo que, a partir dela, acreditamos que a pressão exercida sobre o CNE se deu não pelo órgão Ministério do Esporte, mas, sim por um militante progressista da Educação Física que, chegando ao cargo de Secretário Nacional de Esporte e gozando de prerrogativas e trânsito dentro da máquina governamental, retirou, em condições puramente circunstanciais, embora politicamente guiado, um parecer que estava em vias de ser publicado e que poderia prejudicar sobremaneira a Educação Física. Não conseguimos identificar nesse episódio qual concretamente foi a participação do CBCE e do MEEF, conforme anunciado pelos outros autores.

${ }^{24}$ Mesa-redonda organizada pelo CBCE na 64 ${ }^{\text {a }}$ REUNIÃO ANUAL DA SOCIEDADE BRASILEIRA PARA O PROGRESSO DA CIÊNCIA intitulada Formação profissional em Educação Física: uma antítese que se arrasta... Maranhão, São Luis: UFMA, 2012. Disponível em: https://www.youtube.com/watch?v=WJDxzkvLN14\&list=UUDsdj4NGukumVZ_zpT9bF_w\&index= $1 \&$ feature $=$ plcp Acesso em: 17/03/2014. 
Foi precisamente a partir do protagonismo desse ator social que, na sequência, o Ministério do Esporte ocupou a cena no processo de rediscussão do parecer 138/02. Em resistência ao protagonismo do Ministério do Esporte, o professor Castellani Filho destaca que, por diversas vezes, o CONFEF tentou persuadir o novo relator das Diretrizes, conselheiro Éfren Maranhão, a não aceitar o protagonismo desse órgão de governo tendo tido como resposta que não estava ali para "editar a história".

Nozaki (2004) assinala em sua tese que foi criado um grupo de trabalho a partir do Ministério do Esporte com o objetivo de se criar uma proposta substitutiva. Posteriormente a SESU/MEC convidou o professor Helder Resende da antiga COESP e um representante do grupo de trabalho para presidirem uma comissão oficial para a reformulação das diretrizes. Agregaram-se a essa comissão novos membros da antiga COESP, CBCE e do próprio CONFEF. Sobre o grupo de trabalho criado a partir do Ministério do Esporte o professor Castellani Filho narrou da seguinte forma:

“... A partir daí, foi possível uma nova rodada de negociações e discussões de acordo com o Conselho Nacional de Educação e sob a coordenação do Ministério do Esporte envolvendo o mais amplo espectro da área possível, no sentido de ter, em sessenta dias, um novo documento para aprovação, tendo sido esse o compromisso assumido com o CNE por meio da interlocução com o conselheiro Efrem Maranhão. Para tanto, foram convidados todos os seguimentos da área da Educação Física: CBCE, LEPEL, CONDIESEF, CONFEF, EXENEEF, porque não havia hipótese política de o documento ser aprovado sem a anuência do CONFEF e CONDIESEF. Seria ingenuidade pensar que poderia bancar o projeto que vinha sendo discutido no CBCE e, simplesmente, por em cima da mesa exigindo a sua aprovação. Foram convidadas, também, pessoas que vinham apresentando trabalhos na área com o professor Nivaldo David e o professor Helder Resende pela sua relação com a SESU, ficando o referido professor responsável pela a realização de diversas plenárias de discussões.” (CASTELLANI FILHO, 2012) ${ }^{25}$

Portanto, ao que parece, buscou-se estabelecer o diálogo democrático entre as diversas representações da Educação Física em busca de avançar na proposição, se não de um

25 Mesa-redonda organizada pelo CBCE na 64 $^{\text {a }}$ REUNIÃO ANUAL DA SOCIEDADE BRASILEIRA PARA O PROGRESSO DA CIÊNCIA. intitulada Formação profissional em Educação Física: uma antítese que se arrasta... Maranhão, São Luis: UFMA, 2012. Disponível em: https://www.youtube.com/watch?v=WJDxzkvLN14\&list=UUDsdj4NGukumVZ_zpT9bF_w\&index= $1 \&$ feature $=$ plcp Acesso em: 17/03/2014. 
documento que atendesse todas as reivindicações dos campos progressista da Educação Física, pelo menos um melhor do que o parecer 138/02. ${ }^{26}$

Depois de várias reuniões a comissão de especialistas apresentou uma proposta de substitutivo ao parecer 138/02 no final de 2003, sendo apreciada em audiência pública no dia 15 de dezembro do mesmo ano. Nos dias 12 e 13 de dezembro de 2003, Grupo de Trabalho Temático "Formação Profissional e Mundo do Trabalho", do Colégio Brasileiro de Ciências do Esporte(CBCE), realizou uma reunião em Vitória, Espírito Santo, analisando-se o referido substitutivo (TAFFAREL e LAKS, 2005). Baseando-se em entendimento anteriores do CBCE e em discussões ocorridas durante a reunião, produziram o documento intitulado "Carta de Vitória" ${ }^{27}$, posicionando-se veementemente contra ao parecer 138/02 e ao parecer substitutivo.

\footnotetext{
${ }^{26}$ Ainda, relata o professor Lino, que se afastou do processo em virtude de não ser uma pessoa bem quista a determinados setores conservadores e, também, pelo interesse que o debate avançasse em meio há um coletivo tão heterogêneo. Tinha consciência que, em virtude do antagonismo de posições no interior desse coletivo, jamais seria possível a aprovação de um documento que representasse as aspirações de apenas um seguimento da área. Desse modo, a estratégia para o momento, seria avançar da configuração conservadora do parecer 138/02.
}

${ }^{27}$ Em reunião ocorrida entre os dias 12 e 14 de dezembro em Vitória - ES, o GTT 6 - Formação Profissional e Mundo do Trabalho do CBCE, discutiu uma pauta pré-agendada para subsidiar o $\mathrm{CBCE} / \mathrm{DN}$, nas políticas de formação profissional, em função dos fatos que cercaram o processo de aprovação das diretrizes, publicou, no documento denominado "Carta de Vitória", endereçada à Direção Nacional do CBCE e aos sócios da entidade, expondo os seguintes encaminhamentos: 01. Inicialmente, nos confessamos bastante surpresos sobre a veiculação nesta semana, via internet, do apoio que o CBCE/DN oferece à proposta da COESP, pois, apesar de ser do conhecimento de que estaríamos reunidos neste período, imaginamos que haveria minimamente alguma consulta ao GTT, a respeito do tema; no entanto, só tomamos conhecimento de tal fato, no sábado, dia 13, já que a mensagem de apoio não veiculou na lista do Grupo. 02. Faz-se importante também, ratificar a posição assumida nesta mensagem em referência no item anterior, de que o CBCE esteve presente de forma concreta nos trabalhos de construção do documento intitulado de "substitutivo" do Parecer CNE 0138/02, através da Professora Zenólia Figueiredo, a qual, inicialmente, "parece" não ter sido convidada nesta condição, mas assim se efetivou durante o processo. O GTT, por maioria de seus membros entende ser esta uma posição elementar, para que a sócia/pesquisadora não se consolide historicamente, como a responsável pelas consequências advindas do substitutivo, se aprovado, por duas razões relevantes: 2.1. A Professora Zenólia Figueiredo está, neste momento, solidária e fiel à posição sustentada pelo CBCE/DN, que já há algum tempo, demonstra uma tendência de apoiar um documento que, em última análise, se apresentasse melhor que o Parece CNE/0138/02. 2.2. A Sócia Pesquisadora, no interior da COESP, por várias vezes provocou embates e conflitos por tentar avançar na proposta da Comissão; em outros espaços, sua posição, por meio de textos e artigos elaborados, de palestras e debates públicos dos quais participou, mostram com clareza, inúmeras discordâncias daquilo que está posto no documento. 03. É necessário resgatar que, durante o XIII CONBRACE, houve um Seminário de Aprofundamento, mediado pelo Prof. Nivaldo Antonio David, membro deste GTT, onde estiveram presentes todo este Comitê Científico, muitos componentes do GTT, dois membros da COESP, quando o debate pontuou claramente quais as questões que, minimamente, deveriam avançar no processo; foi um momento em que, as pessoas que discutem formação profissional no interior deste Colégio, apresentaram de forma inequívoca, os pontos que necessitam de avanços. 04. A respeito do Parecer CNE-CES 0138/02, aprovado pelo Conselho Nacional de Educação, este GT tem claro que o mesmo reúne um amontoado de equívocos epistemológicos, pedagógicos, históricos e de outras montas, o que representa um atraso 
É importante, destacar alguns aspectos relacionados a esse documento. O primeiro é que para um Coletivo que se dispunha a contribuir com a reflexão sobre as políticas públicas de formação para a Educação Física, é no mínimo estranho, se reunir às vésperas da aprovação do substitutivo e se confessar "bastante surpresos com o apoio do $\mathrm{CBCE} / \mathrm{DN}$ à proposta da COESP”. O segundo, é que um documento dessa monta não poderia assumir contornos inquisitórios tão evidentes ao julgar e perdoar a professora Zenólia Figueiredo por ocasião da sua participação no referido processo, alegando que a Sócia Pesquisadora, enquanto representante do $\mathrm{CBCE}$ no interior da COESP, por várias vezes provocou embates e conflitos por tentar avançar na proposta da Comissão. Entretanto, é preciso salientar que a professora Zenólia por meio de textos e artigos elaborados, de palestras e debates públicos dos quais têm participado nos últimos anos, mostra com clareza, inúmeras discordâncias daquilo que está posto na Carta de Vitória.

Além disso, a informação em torno da discordância da referida professora ao substitutivo parece contraditória uma vez que foi a única professora presente na reunião de Vitória a não assinar o documento em pauta. E por último, o documento reporta-se sempre ao Parecer CNE 138/02 e não à proposta substitutiva a ele. Portanto, gera a impressão de que as análises feitas durante a reunião não tiveram como foco de análise a proposta substitutiva.

Com efeito, embora o propósito da Carta de Vitória fosse o de repudiar o substitutivo ao parecer 138/02, revela, nos parece, tão somente uma tática política para tornar pública a posição contrária à aprovação do referido Parecer. Ademais, a Carta de Vitória apresenta um posicionamento do GTT que em sua correlação de forças, apontava para a radicalização da questão. Talvez não fosse essa a posição geral da Entidade CBCE.

Isto posto, o substitutivo foi apreciado e aprovado em audiência pública no dia 15 de dezembro de 2003, convocada pelo CNE. Na audiência o CONFEF se posicionou contra o

de décadas para a área, desqualificando o processo de formação profissional na Educação Física brasileira. Diretrizes Curriculares vinculadas a este Parecer, seriam garantidas e consolidadas por meio dos mecanismos de avaliação, onde os cursos, para receberem credenciamento e/ou recredenciamento, seriam balizados por avaliações, cujos instrumentos implicariam relacionar o projeto pedagógico desses cursos com as diretrizes curriculares para a área, garantindo assim a influência do referido parecer nos currículos das diversas IES que oferecem formação profissional em Educação Física, subsumindo os primeiros, ao segundo. Para dirimir qualquer dúvida, esclarecemos "nossa rejeição veemente" ao Parecer CNE/CES 0138/02. 05. Por fim, tornando-se o principal ponto de pauta desta reunião, entre as estratégias definidas pelos componentes, encaminhamos cópias de nosso parecer "sobre a proposta substitutiva" da COESP, pelas mãos do Prof. Nivaldo Antônio David, indicado para representar o Comitê Científico nas Audiências Públicas que o Conselho Nacional de Educação realizará em Brasília, dias 15 e 16 deste mês, entregando ao/a Representante do CBCE/DN, a posição construída nesta reunião de Vitória. 
substitutivo e defendeu o parecer 138/02. O MEEF criticou o documento, mas, em sentido contrário, contestando a divisão da formação em licenciatura e bacharelado e suas ligações com a atual fase do capitalismo. Apoiaram o substitutivo o CBCE, o Ministério do Esporte e o Conselho de Dirigentes das Instituições de Ensino Superior de Educação Física-CONDIESEF, fundamentando-se no consenso até ali alcançado.

É interessante analisar que em sendo o documento aprovado, considerado por grande monta de pesquisadores da Educação Física, um documento conservador e retrógrado, atrelado aos interesses do mercado emergente da Educação Física, o que justificaria o posicionamento contrário à sua aprovação pelo CONFEF? Qual seriam as razões para o CONFEF votar contra o parecer 058/04? Nesta audiência, há relatos que o sistema CONFEF/CREF criticou o documento substitutivo adjetivando-o de "colcha de retalhos" e posicionou-se em defesa do Parecer CNE/CP 0138/2002 (TAFFAREL, 2003). Isso demonstra que o CONFEF/CREF não se sentiu contemplado com o document o aprovado por esse coletivo. Com isso, não se pode afirmar que o parecer 058/04 tenha sido objeto do seu protagonismo.

As análises e reflexões que imputam responsabilidade e protagonismo direto do CONFEF ao processo de normatização da formação profissional em Educação Física estariam equivocadas? Ficam os questionamentos para refletirmos à luz dos fatos que envolvem a constituição das diretrizes curriculares da Educação Física sobre a sua verdadeira orientação político-pedagógica.

Ainda sobre a posição do CBCE nesse processo, Taffarel (2003) assinala que o CBCE, contraditoriamente à sua função de entidade acadêmicocientífica, reafirma e/ou corrobora uma resolução que não considera os avanços da área no que diz respeito à teoria do conhecimento e a organização curricular. Ao contrário disso, considerarmos que o CBCE enquanto entidade científica tem a responsabilidade de fomentar o debate teórico e posições ideológicas heterogêneas. Portanto, não cabe a uma entidade científica, notadamente aberta ao processo dialético de construção de ideias e teorias sobre as diversas temáticas que envolvem a produção científica da área ser representante de um único postulado que não possui consenso interno. Cabe sim, à uma entidade desse nível, compreendendo o momento histórico e as possibilidades de avanço em relação ao documento anterior, contribuir para a construção de um documento mais coerente, que pudesse, em condições negociadas, refletir os interesses da categoria dos professores de Educação Física.

Castellani Filho (2012) reafirma que a divisão da formação não foi um movimento do CONFEF e nem foi um movimento da Educação Física, foi fruto de uma lógica maior iniciada nos finais do anos 70 e início do anos 80 , já presente na Resolução 03/87 que previa a formação 
em ambas as habilitações, muito embora fosse figurada como uma licenciatura ampla voltada para a intervenção profissional em todos os espaços de trabalho. Ainda observa esse autor que,

A questão central que está posta é que nós não tivemos nos anos 80, 90 e início da década do século XXI, condições políticas na correlação de forças estabelecidas, de termos a hegemonia do processo e, diante da ausência de hegemonia, nós construímos o que foi possível. Seria, mais tranquilo, colocar o projeto em cima da mesa e exigir que o mesmo fosse aprovado ou, ao contrário, não participaria. Recusaram de participar, o movimento estudantil e a LEPEL que, coincidentemente, apresentaram um documento ipsis litteris igual. Acredito que essas coletivos se articularam bem nesse movimento, mas, se preocupa com o que chamou de um certo aparelhamento da instância estudantil, provocado por um processo muito mais de inculcação do que de educação sofrida por determinados grupos. $\mathrm{O}$ movimento de bater às portas do Conselho Nacional em torno da revogação das atuais diretrizes é, no mínimo, irresponsável, uma vez que a correlação de forças políticas e muito pior do que àquela do início do século XXI.(CASTELLANI FILHO, 2012) 2 $^{28}$

Ao finalizarmos esse tópico, esperamos ter contribuído com a discussão sobre o processo de constituição histórica das Diretrizes Curriculares da Educação Física, especialmente, no sentido de desmitificar a ideia de que a Resolução CNE/CES No 07/2004 tenha sido fruto de ingerência exclusiva do CONFEF sobre o CNE.

Pelo que apresentamos aqui, houve ingerências diversas, tanto no sentido da construção de um documento voltado aos interesses de setores conservadores como também de setores progressistas da Educação Física.

Esses dados e reflexões são importantes, pois nos ajudam a compreender as Diretrizes Curriculares da Educação Física exatamente como elas são, um documento contraditório que expressa bem a correlação de forças políticas e interesses antagônicos em seu processo de elaboração. A contradição nesse caso, não significa demérito ao documento, ao contrário, representa os seus avanços e retrocessos, seus limites e possibilidades e, o mais importante, o reconhecimento de que a luta principal está completamente em aberto no interior das universidades, faculdades e centros universitários de todo o país, na elaboração e execução desses currículos. É precisamente nesse espaço que a luta é mais relevante e onde a correlação de forças é também desfavorável aos segmentos mais progressistas da Educação Física.

28 Mesa-redonda organizada pelo CBCE na 64 $^{\text {a }}$ REUNIÃO ANUAL DA SOCIEDADE BRASILEIRA PARA O PROGRESSO DA CIÊNCIA. intitulada Formação profissional em Educação Física: uma antítese que se arrasta... Maranhão, São Luis: UFMA, 2012. Disponível em: https://www.youtube.com/watch?v=WJDxzkvLN14\&list=UUDsdj4NGukumVZ_zpT9bF_w\&index= 1\&feature=plcp Acesso em: 17/03/2014. 
Portanto, a luta pela revogação das atuais diretrizes não parece ser uma boa estratégia em virtude dos setores progressistas da Educação Físíca estarem ainda mais frágeis e desarticulados politicamente.

O Parecer aprovado pelo CNE de $n^{\circ}$ 058/04 e materializado pela Resolução CNE/CES $n^{\circ} 07 / 2004$ em vigor,

....apesar dos seus problemas e dubiedades epistemológicos, como exemplo os inúmeros termos utilizados para representar o objeto da educação física, como se fossem todos advindos de uma única matriz epistemológica, há de se considerar que essa resolução não apriosiona os currículos de formação das IFES, ao contrário, amplia as possibilidades de interpretação para além do campo da saúde, superando a proposição do Parecer CNE/CP 138/20027, articulado pelo Conselho Federal de Educação Física e quase viabilizado oficialmente (FIGUEIREDO e MARQUES, 2013, p. 1-14).

Reconhecer os limites das diretrizes e identificar possibilidades de construção e execução de currículos críticos no interior dos cursos, talvez seja uma saída mais frutífera às aspirações de um processo formativo mais humano e crítico no interior dos cursos de Educação Física. Além disso, é preciso que os professores e alunos do campo progressista, reconhecendo os limites da atual conjuntura política, procurem se unir a fim de conquistar avanços para a nossa área.

\section{7 - Diretrizes Curriculares da Educação Física: reconhecendo limites, identificando possibilidades}

A argumentação sobre a viabilidade das Diretrizes Curriculares da Educação Física tem sido tarefa árdua para os pesquisadores que, tomando o lócus de formação profissional em suas universidades como objeto de análise, vêm tentando contribuir com o arcabouço de conhecimento neste campo.

Compartilho, portanto, dessa mesma angústia de buscar possibilidades num documento em que alguns pesquisadores de tradição marxista, na qual me insiro, vêm negando com absoluta veemência. $\mathrm{O}$ argumento principal para a negação estaria na sua vinculação com o projeto neoliberal implantado no Brasil no final do século $\mathrm{XX}$, que vem redesenhando as políticas de Estado para a economia e, consequentemente, para os demais setores, entre eles, a educação em seu processo formativo. Em virtude disso, as atuais diretrizes curriculares, a partir 
do modelo de competências, contribuiria para subsumir a formação aos interesses mais imediatos dos capitalistas vinculados ao mercado de trabalho emergente da Educação Física, tendo como regente/maestro o CONFEF. Assim,

\begin{abstract}
As atuais diretrizes para a formação em Educação Física inclinam a formação profissional da área para o atendimento aos anseios mercadológicos. Primeiro, porque aponta habilidades profissionais como sendo competências, naquilo que parece ser intencional e estratégico para não trazer à tona as necessidades mais complexas do aporte teórico; fica expressa a necessidade de que o egresso esteja preparado para resolver os problemas imediatos, os anseios dos indivíduos participantes das práticas corporais. (VENTURA, 2010, p. 149)
\end{abstract}

Não podemos afirmar e nem temos dados empíricos que demonstrem essa determinação das diretrizes sobre a formação, reduzindo o aluno a um mero executor de tarefas. Há sim, especulações de que esse modelo irá contribuir para esse tipo de formação. Em nosso entendimento, não existem pesquisas empíricas que comprovem os desdobramentos na formação e atuação profissional do paradigma da racionalidade técnica, ou seja, não conseguimos ainda visualizar com clareza e rigor científico essas determinações.

Devemos ressaltar, conforme demonstrado no tópico anterior, que o movimento de reflexão em torno dos pareceres CNE n 138/02 e seu substitutivo promoveram modificações consideráveis na atual diretriz curricular, Resolução CNE/CES 07/2004, reconhecida por grande parte dos pesquisadores da área.

Se o atual marco regulatório não nos permite ter uma licenciatura unificada ou ampliada conforme alguns pesquisadores e o MEEF defendem, também não podemos considerá-la essencialmente conservadora. Ela é fruto de uma construção histórica em que diversos segmentos da Educação Física, participantes em maior ou menor proporção, contribuíram para tencioná-la e transformá-la num documento conciliatório que expressa as contribuições teóricas do campo progressista da Educação Física e de setores conservadores ligados ao mercado emergente, reconhecidamente efêmero da Educação Física. Portanto, o que se deu foi luta política na real acepção da palavra, luta por hegemonia e não um jogo de futebol, um FLA x FLU ou um BA x VI, o ser a favor ou contra. A elaboração das diretrizes se deu em condições negociadas e não se pode considerá-la exclusivamente como um instrumento a serviço dos interesses mercadológicos.

Sem dúvida, existe uma dimensão técnico-instrumental priorizada pelos bacharelados, uma vez que a sua conotação no âmbito da Educação Física no Brasil não é de um profissional generalista, que se ocupe da pesquisa e da produção de conhecimento como objeto de 
intervenção profissional (BETTI, 1992), ao contrário, atuará como trabalhador na área não escolar da Educação Física. Entretanto, o currículo oferece margens, a partir da sua configuração, para atuar nesse mercado de forma crítica. Analisando a divisão das diretrizes curriculares da Educação Física (CASTELLANI FILHO e CARVALHO, 2006), assinalam que o modelo curricular preconizado pela Resolução CFE No 03/87 trouxe avanços em sua organização curricular, porém, com o foco na intervenção profissional. Observam que essa estratégia abriu o espaço para a criação do bacharelado. Avaliam que a licenciatura se manteve pelo caráter ampliado de atuação no mercado profissional de trabalho. Ressaltam que as orientações oferecidas pelas atuais diretrizes, buscam a "explicitação do conhecimento necessário à formação do profissional", ou seja, não mais priorizando o campo de sua intervenção. Eliminou-se a ideia de licenciatura ampliada ou de caráter ampliado na atuação profissional, colocando o foco numa licenciatura stricto sensu, para intervenção na Educação Básica.

Estudos mais recentes produzidos por Figueiredo e colaboradores (2006, 2009 e 2013), além de destacar experiências no processo de elaboração e execução curricular reconhecidamente críticas, revelam determinadas contradições no processo de análise das diretrizes curriculares da Educação Física. Assim, parece existir,

(...) uma determinação quase direta que se tem atribuído às diretrizes curriculares para os cursos de educação física, como aquelas exclusivamente responsáveis pelos problemas da formação profissional, desconsiderando dimensões históricas importantes, tais como: que a área possui problemas/desafios no campo epistemológico que é anterior a essa legislação e esses problemas ainda não estão solucionados; que há muito buscamos qualificar os nossos cursos, para além das determinações legais, lembrando que, nem sempre, mesmo na licenciatura plena nos moldes da Resolução 03/87, obtivemos sucesso ou alcançamos nossas intenções de formação qualificada; que a discussão da formação não deve se pautar, exclusivamente, pelo mercado de trabalho, principal alvo de "ataques" dessa legislação, quando rompe com a viabilidade de uma única formação, nos moldes da antiga licenciatura plena. (FIGUEIREDO E MARQUES, 2013, p.1-14)

Nesse sentido, talvez a tarefa seja, para nós educadores vinculados ao processo de formação profissional, para além da negação das atuais diretrizes buscar identificar nesse documento aquilo que se constitui em orientação ou em aprisionamento legal em relação à construção e execução dos currículos (FIGUEIREDO E MARQUES, 2013).

Nesse sentido, o modo como se interpreta as diretrizes curriculares é fundamental na tarefa de construção de um currículo avançado, para além do discurso submisso ao aspecto 
legal. Assim, o currículo prescrito, permite “[...] um vasto leque de significações e intenções cruzadas que se colocam em circulação [...] contém ambiguidades, contradições e omissões que criam algum campo de manobra no domínio da interpretação" (PARASKEVA, 2008, p. 141).

Desse modo, podíamos criticar as fragilidades explícitas dessa legislação referentes à formação docente no País, no que diz respeito ao político e ao conteúdo propriamente dito, mas, também, questionar como essa legislação tem sido interpretada pelas IES's. Quando as diretrizes curriculares tornam-se aprisionamentos para a área da educação física e quando são somente orientações, transformadas em "camisa de força" que servem, intencionalmente, para justificar (des) interesses de professores formadores e/ou de gestores das instituições, sejam públicas ou privadas, em efetivar uma formação de qualidade (FIGUEIREDO E MARQUES, 2013).

Assim, a partir da análise do currículo em um curso de licenciatura de Universidade Pública na região sudeste do país, embasado pelas Resoluções CNE/CP 01 e 02/2002 encontraram os seguinte dados, conforme quadro abaixo:

\section{Quadro VIII : Orientações e aprisionamentos legais em relação às Diretrizes de Formação de Professores}

\begin{tabular}{|l|l|}
\hline \multicolumn{1}{|c|}{ Orientações } & \multicolumn{1}{|c|}{ Aprisionamentos legais } \\
\hline O foco na docência como base da formação & $\begin{array}{l}\text { A noção linear de competência e da ideia de que a } \\
\text { formação deverá garantir a constituição dessa } \\
\text { competência objetivada na educação básica }\end{array}$ \\
\hline $\begin{array}{l}\text { A flexibilização da organização curricular por eixos } \\
\text { de conhecimentos }\end{array}$ & $\begin{array}{l}\text { A indicação metodológica de que a aprendizagem } \\
\text { deverá ser orientada pelo princípio traduzido pela } \\
\text { "ação-reflexão-ação" que busca resolver as "situações- } \\
\text { problemas" como uma das estratégias didáticas } \\
\text { privilegiadas. }\end{array}$ \\
\hline $\begin{array}{l}\text { A ampliação de carga horária nos estágios } \\
\text { supervisionados e nos componentes de prática de } \\
\text { ensino }\end{array}$ & \\
\hline
\end{tabular}

Fonte: (FIGUEIREDO e MARQUES, 2013).

Com relação às orientações emanadas pelas resoluções CNE/CP nº 01 e 02 de 2002, o foco na docência como base da formação é interpretada pelo currículo de formação analisado, como um processo de tornar-se professor mediante as circunstâncias de exercer a docência. Já a flexibilização da organização curricular por eixos de conhecimentos, sinalizam o tipo de atividade de ensino e de aprendizagem que compõem o planejamento e a ação dos professores formadores. A ampliação de carga horária nos estágios supervisionados e nos componentes de 
prática de ensino contribuiu para a multiplicação de experiências e reflexões sobre o ambiente em que a docência irá acontecer (FIGUEIREDO e MARQUES, 2013).

Ao mesmo tempo, encontraram como aprisionamentos dessa legislação de formação de professores os seguintes aspectos: a noção linear de competência. O que se quer dizer por competências? No ambiente pesquisado as competências foram interpretadas como objetivos, capacidades, habilidades, atitudes, ora como conteúdos específicos. Nesse caso, a noção de competências não foi considerada no currículo de formação de professores. A indicação metodológica de que a aprendizagem deverá ser orientada pelo princípio traduzido pela "açãoreflexão-ação" que busca resolver as "situações-problemas" como uma das estratégias didáticas privilegiadas. Definitivamente, trata-se de um aprisionamento metodológico e não cabe a uma legislação definir práticas educativas (FIGUEIREDO E MARQUES, 2013).

Portanto, observa-se por esse trabalho, que existe margem para potencializar as orientações e subverter as amarras legais das diretrizes curriculares no processo de elaboração e execução curricular. Nesse sentido, é importante que a comunidade acadêmica e, em especial, professores e alunos, exerçam a sua capacidade crítica e criadora a serviço desse processo. Quanto maior o conhecimento em torno das diretrizes curriculares e das teorias inovadoras de currículo, maiores serão as possibilidades de produção de uma matriz curricular avançada para os cursos de Educação Física.

Com o intuito de avaliar avanços e retrocessos em relação às atuais diretrizes curriculares da Educação Física, recuperaremos as principais críticas/reivindicações da categoria dos professores expressa nos artigos publicados em periódicos na década de 90 e primeiros anos do século XXI. O objetivo aqui é verificarmos se essas demandas foram contempladas nas novas diretrizes. Antes, porém, apresentaremos um quadro com a produção do período posterior à publicação das diretrizes de 2002 a 2013.

Quadro IX: Produção de artigos sobre a formação profissional de 2002 a 2013

\begin{tabular}{|c|c|c|c|c|}
\hline Ano de publicação & RBCE & Revista Movimento & $\begin{array}{c}\text { Revista Pensar a } \\
\text { Prática }\end{array}$ & Total/Ano \\
\hline 2002 & 2 & 1 & & 3 \\
\hline 2003 & & 1 & 1 & 2 \\
\hline 2004 & & & & 3 \\
\hline 2005 & & & 1 & 1 \\
\hline 2006 & & & 3 & 1 \\
\hline
\end{tabular}




\begin{tabular}{|c|c|c|c|c|}
\hline 2008 & & 1 & 2 & 1 \\
\hline 2009 & 1 & 1 & 2 & 3 \\
\hline 2010 & 1 & 1 & 1 & 3 \\
\hline 2011 & 1 & 1 & 2 & 2 \\
\hline 2012 & & 1 & 13 & Total Geral \\
\hline 2013 & 5 & 7 & & 25 \\
\hline Total por Revista & & & & \\
\hline
\end{tabular}

Fonte: próprio autor

Ao compararmos a produção acadêmica no período de 2002 a 2013 com o período anterior, 1990 a 2001, percebemos que houve um crescimento no total de artigos publicados. No primeiro período foram publicados 16 artigos contra 25 do segundo período. Se no primeiro estudo a RBCE teve o maior número de artigos publicados, desta vez, ficou em terceiro com apenas 5 artigos, atrás da Revista Movimento com 7 e da Revista Pensar a Prática com 13 artigos. O ano de maior produção foi 2010, com 04 artigos, mas sem registrar nenhuma motivação especial que tenha causado essa elevação.

Analisaremos agora as demandas da formação profissional, ou seja, as críticas/reivindicações ao modelo curricular aprovado em 2002(Licenciatura) e 2004(Bacharelado) presentes na produção acadêmica no período em pauta.

Quadro X: Produção sobre formação profissional após publicação das Diretrizes Curriculares da Educação Física na Revista Brasileira de Ciências do Esporte

\begin{tabular}{|c|c|c|c|c|c|}
\hline Ano & Autor(es) & Instituição & Temática & Problemas abordados & Proposições \\
\hline 2002 & $\begin{array}{l}\text { Nivaldo } \\
\text { Antonio } \\
\text { Nogueira } \\
\text { David }\end{array}$ & UFG & $\begin{array}{l}\text { A Formação de professores para } \\
\text { a Educação Básica: dilemas } \\
\text { atuais para a Educação Física }\end{array}$ & $\begin{array}{l}\text { A ação curricular está voltada } \\
\text { para a racionalidade prática ou } \\
\text { para um modelo de formação } \\
\text { baseada nas competências } \\
\text { forjadas a partir das situações- } \\
\text { problema }\end{array}$ & $\begin{array}{l}\text { Currículo construído a partir } \\
\text { do livre exercício da } \\
\text { autonomia universitária com } \\
\text { enfoque crítico e humanista. }\end{array}$ \\
\hline
\end{tabular}

Fonte: Revistas RBCE

Quadro XI: Produção sobre formação profissional após publicação das Diretrizes Curriculares da Educação Física na Revista Movimento

\begin{tabular}{|c|c|c|c|c|c|}
\hline Ano & Autor(es) & Instituição & Temática & Problemas abordados & Proposições \\
\hline 2004 & $\begin{array}{l}\text { Zenólia C. } \\
\text { Campos } \\
\text { Figueiredo }\end{array}$ & UFES & 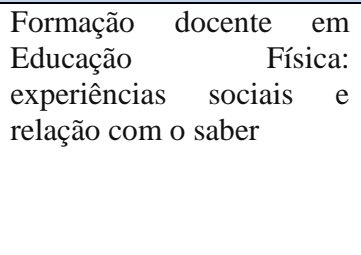 & $\begin{array}{l}\text { Influência das experiências } \\
\text { sóciocorporais na formação do } \\
\text { professor de Educação Física }\end{array}$ & $\begin{array}{l}\text { Refletir sobre a formação } \\
\text { de modo a compreender e } \\
\text { contemplar } \\
\text { experiências sociais do } \\
\text { aluno do curso de } \\
\text { Educação Física não } \\
\text { apenas como forma de }\end{array}$ \\
\hline
\end{tabular}




\begin{tabular}{|c|c|c|c|c|c|}
\hline & & & & & $\begin{array}{l}\text { interação entre a cultura de } \\
\text { origem e a cultura de } \\
\text { formação, mas também } \\
\text { como uma maneira de } \\
\text { intervir e romper com } \\
\text { algumas concepções } \\
\text { incorporadas e } \\
\text { transferidas para os cursos } \\
\text { de formação. }\end{array}$ \\
\hline 2008 & $\begin{array}{l}\text { Ieda Parra } \\
\text { Barbosa- } \\
\text { Rinaldi }\end{array}$ & $\begin{array}{l}\text { Universid } \\
\text { ade } \\
\text { Estadual } \\
\text { de } \\
\text { Maringá }\end{array}$ & $\begin{array}{l}\text { Formação Inicial em } \\
\text { Educação Física: uma nova } \\
\text { epistemologia da prática } \\
\text { docente }\end{array}$ & $\begin{array}{l}\text { Fragmentação do conhecimento, } \\
\text { segmentação entre teoria e prática, a } \\
\text { visão linearizada dada às tarefas de } \\
\text { ensino e aos processos de } \\
\text { aprendizagem, as concepções de } \\
\text { ensino como processo de preparação } \\
\text { técnica e a prática como um } \\
\text { processo técnico de intervenção. }\end{array}$ & $\begin{array}{lr}\text { Formar profissionais } & \text { que } \\
\text { sejam capazes de } \\
\text { compreender } \\
\text { complexidade a } \\
\text { realidades sociais nas } \\
\text { quais estamos envolvidos } \\
\text { e contribuir para a sua } \\
\text { transformação, para que os } \\
\text { mesmos sejam produtores, } \\
\text { transformadores, co- } \\
\text { criadores e não } \\
\text { reprodutores de saberes. }\end{array}$ \\
\hline 2012 & $\begin{array}{l}\text { Lovane } \\
\text { Maria } \\
\text { Lemos, Luiz } \\
\text { Fernando } \\
\text { Camargo } \\
\text { Veronez, } \\
\text { Márcia } \\
\text { Morschbach } \\
\text { er, Vilmar } \\
\text { José Both }\end{array}$ & $\begin{array}{l}\text { Universid } \\
\text { ade } \\
\text { Federal de } \\
\text { Pelotas }\end{array}$ & $\begin{array}{l}\text { As contradições do } \\
\text { processo de elaboração das } \\
\text { Diretrizes Curriculares } \\
\text { Nacionais dos Cursos de } \\
\text { Formação em Educação } \\
\text { Física e os movimentos de } \\
\text { resistência à submissão ao } \\
\text { mercado }\end{array}$ & $\begin{array}{l}\text { Currículos flexíveis pautados pelo } \\
\text { desenvolvimento de habilidades e } \\
\text { competências; } \\
\text { Aligeiramento e fragmentação - } \\
\text { divisão das áreas de conhecimento e } \\
\text { de formação entre licenciatura e } \\
\text { bacharelado; } \\
\text { Perfis profissionais flexíveis e } \\
\text { adaptáveis às constantes mutações } \\
\text { do mercado }\end{array}$ & $\begin{array}{l}\text { Revogação das atuais } \\
\text { diretrizes em nome da } \\
\text { Licenciatura Ampliada ou } \\
\text { Unificada. }\end{array}$ \\
\hline
\end{tabular}

Fonte: Revistas Movimento

\section{Quadro XII: Produção sobre formação profissional após publicação das Diretrizes Curriculares da Educação Física na Revista Pensar a Prática}

\begin{tabular}{|c|c|c|c|c|c|}
\hline Ano & Autor(es) & Instituição & Temática & Problemas abordados & Proposições \\
\hline 2006 & $\begin{array}{l}\text { Fernanda } \\
\text { Simone } \\
\text { Lopes de } \\
\text { Paiva, } \\
\text { Nelson } \\
\text { Figueiredo } \\
\text { Andrade } \\
\text { Filho e } \\
\text { Zenólia } \\
\text { Cristina } \\
\text { Campos } \\
\text { Figueiredo }\end{array}$ & UFES & $\begin{array}{l}\text { Formação Inicial e } \text { o } \\
\text { Currículo no Cefd/Ufes }\end{array}$ & $\begin{array}{l}\text { A formação docente } \\
\text { perspectiva de análise de ser } \\
\text { professor; } \\
\text { construção do saber docente } \\
\text { apoiado em práticas dialógicas } \\
\text { que favoreçam a compreensão do } \\
\text { saber-fazer escolar; } \\
\text { flexibilização curricular e a } \\
\text { necessidade de "articulação" } \\
\text { entre teoria e prática nos cursos } \\
\text { de formação docente }\end{array}$ & $\begin{array}{l}\text { Currículo com disciplinas } \\
\text { curriculares obrigatórias, } \\
\text { perspectivadas na e com } \\
\text { atitude dialógica } \\
\text { contemplando os conheci- } \\
\text { mentos da Formação Comum } \\
\text { e do Conhecimento da Área; } \\
\text { Outras formas para } \\
\text { construção e experimentação } \\
\text { do conhecimento necessário à } \\
\text { formação de professores de } \\
\text { educação física. São elas: } \\
\text { seminários de estudo para } \\
\text { introdução e deu } \\
\text { aprofundamento de de- } \\
\text { terminado tema, seminários } \\
\text { articuladores das disciplinas } \\
\text { curriculares de cada semestre } \\
\text { do curso, oficinas e outros } \\
\text { projetos e atividades que } \\
\text { integram os conhecimentos } \\
\text { advindos da experiência e de } \\
\text { cultura geral e profissional. }\end{array}$ \\
\hline 2009 & & UFES & 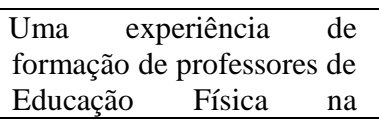 & $\begin{array}{l}\text { Noção de currículo como prática; } \\
\text { Professor sujeito ativo de suas } \\
\text { práticas; }\end{array}$ & $\begin{array}{l}\text { Experiências curriculares em } \\
\text { torno da experiência do } \\
\text { formar-se professor }\end{array}$ \\
\hline
\end{tabular}




\begin{tabular}{|l|l|l|l|l|}
\hline $\begin{array}{l}\text { Zenólia } \\
\text { Christina } \\
\text { Figueiredo }\end{array}$ & $\begin{array}{l}\text { perspectiva do formar-se } \\
\text { professor }\end{array}$ & $\begin{array}{l}\text { Possibilidades curriculares, } \\
\text { tempos espaços, pensados para } \\
\text { trabalhar esse entendimento e o } \\
\text { sentimento de formar-se } \\
\text { professor. }\end{array}$ \\
\hline
\end{tabular}

Fonte: Revistas Pensar a Prática

Os artigos selecionados para a análise das críticas/reivindicações no campo do currículo de formação profissional em Educação Física, como no quadro anterior, obedeceram ao critério da proximidade com o tema pesquisado. Portanto, embora tenham sido identificados 25 artigos que abordavam o tema formação profissional, apenas 06 se detiveram em analisar as diretrizes curriculares atuais. Os posicionamentos seguem denunciando a vinculação das atuais normas curriculares com os interesses do sistema capitalista, mais especificamente, o mercado da Educação Física, porém notamos um crescimento de produções que se propõem a fazer análises subjacentes à questão das diretrizes, sobretudo, enfocando a estrutura e a dinâmica curricular no interior dos cursos de Educação Física. Nesse sentido, destaca-se a professora Zenólia Figueiredo e colaboradores (2004, 2006 e 2009) com artigos que analisam a experiência curricular da UFES, na perspectiva dos saberes docentes e do formar-se professor.

Apresentaremos agora um quadro comparativo em torno das críticas/reivindicações em relação à formação profissional no período que antecedeu a elaboração das diretrizes e de 2004 a 2013, período que sucede a oficialização da mesma.

\section{Quadro XIII: Comparativo entre as críticas/reivindicações da formação profissional antes e depois das diretrizes curriculares atuais.}

\begin{tabular}{|c|c|}
\hline 1990 a 2001 & 2002 a 2013 \\
\hline $\begin{array}{l}\text { - Formação difusa e inconsistente no nível } \\
\text { da licenciatura; } \\
\text { - Formação essencialmente técnica com } \\
\text { base nas ciências biológicas e } \\
\text { psicológicas; } \\
\text { - Professores desqualificados para lidar com } \\
\text { os aspectos pedagógicos no currículo; } \\
\text { - Currículo disciplinar, fragmentado e } \\
\text { linear; } \\
\text { Dicotomia entre a teoria e a prática na } \\
\text { apreensão do conhecimento da Educação } \\
\text { Física e no estágio supervisionado; } \\
\text { Formação inconsistente para atuar na } \\
\text { Educação Básica; } \\
\text { Falta de interdisciplinaridade e do trabalho } \\
\text { coletivo nos espaços de formação } \\
\text { profissional; } \\
\text { Ausência de reflexão no processo de } \\
\text { formação; } \\
\text { Currículo a partir da Resolução 03/87 } \\
\text { voltado para o atendimento dos interesses }\end{array}$ & 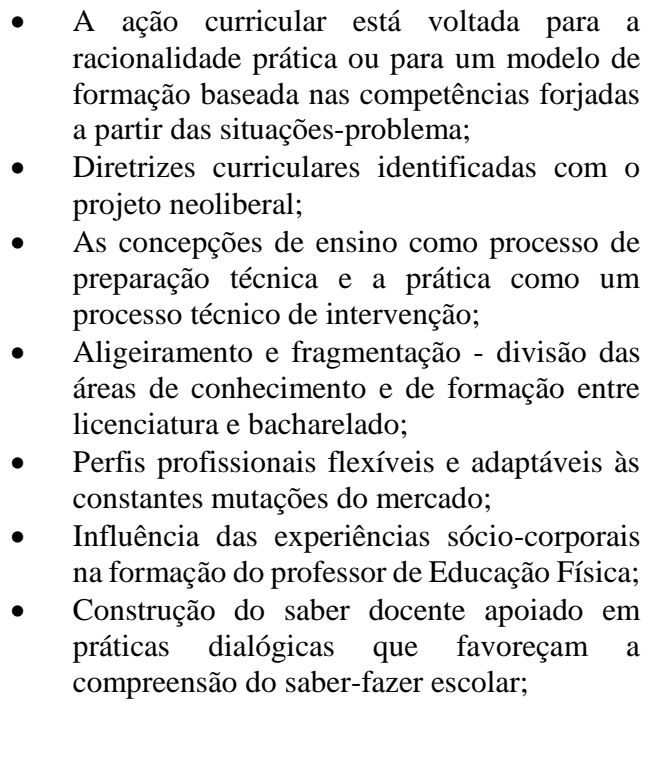 \\
\hline
\end{tabular}




\begin{tabular}{|c|c|}
\hline $\begin{array}{l}\text { do mercado emergente da Educação } \\
\text { Física; } \\
\text { Desconhecimento da realidade docente } \\
\text { durante a formação profissional; } \\
\text { - Ausência de experiências práticas em } \\
\text { relação à docência; } \\
\text { - Ensino artificializado; } \\
\text { - Vinculação dos currículos dos cursos de } \\
\text { Educação Física ao projeto neoliberal. }\end{array}$ & 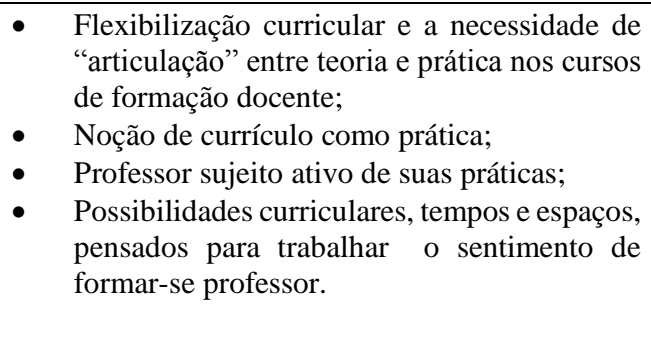 \\
\hline
\end{tabular}

Fonte: próprio autor

A partir dos dados apresentados no quadro comparativo acima, é possível avaliar se as críticas/reivindicações ao currículo de formação baseado na Resolução 03/87 ainda persistem quando analisamos o modelo curricular atual.

Ao compararmos os dados, percebemos que algumas críticas presentes na década de 90 não aparecem mais na primeira década do século XXI. Assim, tendo como referência as publicações nos periódicos pesquisados, apresentamos alguns problemas relacionados à formação profissional que não se encontram mais presentes na crítica às atuais diretrizes curriculares: formação difusa e inconsistente no nível da licenciatura; formação essencialmente técnica com base nas ciências biológicas e psicológicas; formação inconsistente para atuar na Educação Básica; currículo disciplinar, fragmentado e linear; falta de interdisciplinaridade e do trabalho coletivo nos espaços de formação profissional; desconhecimento da realidade docente durante a formação profissional; ausência de experiências práticas em relação à docência; ensino artificializado.

Buscando interpretar os dados acima que apontam para a ausência de determinados limites antes ressaltados e agora não mais, entendemos que, embora o paradigma da saúde ainda faça parte da formação profissional em Educação Física, percebe-se que as críticas a ele não são mais tão contundentes como eram na década de 90 . Talvez isso se justifique em virtude da superação do ser contra ou a favor de nossa inserção na área da saúde para passar a questionar a compreensão de saúde que deve prevalecer quando se pretende atuar no sistema público de saúde brasileiro. Assim, é possível colocar em xeque a competência da fisiologia/biomecânica no processo de formação do profissional da saúde. Além disso, é possível perceber que as preocupações dos estudiosos que criticam as novas diretrizes se voltam para o paradigma da racionalidade técnica.

Também não se fala muito na dicotomia teoria e prática no processo de formação profissional. Talvez as alterações na estrutura curricular colocando a prática e a pesquisa ao longo do curso e a tornando-a condição essencial para a formação profissional tenha contribuído 
para a superação desse limite. A falta de interdisciplinaridade parece ser outro aspecto superado na medida em que havia diversas críticas ao currículo em virtude da falta de integração e de diálogo entre as disciplinas.

O conhecimento da realidade objetiva que no passado se constituía em uma das principais fragilidades da formação raramente é abordado e, quando acontece, se insere na crítica ao conceito de simetria invertida ${ }^{29}$, ou seja, de que as experiências em relação à realidade prática se dão no plano do "aprender a fazer" ou com o objetivo de resolver situações-problemas de modo específico, superficial e descontextualizado. Nesse caso, achamos que não existem amarras que determinem esse tipo de prática, uma vez que a universidade e professores gozam de autonomia em relação à prática pedagógica. Ademais não é tarefa das diretrizes estabelecer metodologias de ensino.

Antes de darmos prosseguimento à análise em torno da crítica atual às diretrizes, gostaríamos de ressaltar um aspecto curioso sobre esse processo. Ao contrário da década de 90, onde a denúncia dos problemas relacionados à formação profissional partia das pesquisas em torno do currículo vivido, ou seja, da pesquisa empírica relacionada com o processo formativo derivado e baseado na Resolução 03/87, nos anos que precedem a publicação das novas diretrizes curriculares da Educação Física, os problemas se referem muito mais a uma possível determinação da formação a partir dos documentos das Resoluções CNE/CP nº 01 e 02/2002 e CNE/CES no 07/2004. Assim, quando analisamos os problemas relacionados à formação no período subsequente à publicação das novas diretrizes curriculares, vemos poucos estudos sobre a dinâmica curricular. Portanto, encontramos as seguintes críticas ao modelo curricular atual: a ação curricular está voltada para a racionalidade prática ou para um modelo de formação baseada nas competências forjadas a partir das situações-problema; Diretrizes curriculares identificadas com o projeto neoliberal; As concepções de ensino como processo de preparação técnica e a prática como um processo técnico de intervenção; Aligeiramento e fragmentação divisão das áreas de conhecimento e de formação entre licenciatura e bacharelado; Perfis profissionais flexíveis e adaptáveis às constantes mutações do mercado.

\footnotetext{
${ }^{29}$ Stecanela e Thomé (2007), traz que a simetria invertida é um "processo de espelhamento ou de vários espelhamentos, pelo qual o professor, vivendo o papel de aluno apreende ou ressignifica o papel de professor" (p. 5). Nesse sentido, o parecer CNE/CP 9/2001, coloca que a compreensão desse fato evidencia a "necessidade de que o futuro professor experiencie, como aluno, durante todo o processo de formação, as atitudes, modelos didáticos, capacidades e modos de organização que se pretende venham a ser concretizados nas suas práticas pedagógicas" (p. 31).
} 
Até aqui, a crítica é formulada tendo como pressuposto a vinculação das atuais diretrizes ao processo de reestruturação produtiva e ao projeto neoliberal que produziu uma série de reformas na educação e na formação de profissionais, dentre eles, os professores de Educação Física. Para esses pesquisadores, as diretrizes tanto de formação de professores (Licenciatura) como a diretriz de Gradução (Bacharelado), estão comprometidas com uma formação pragmática, voltada exclusivamente para o mercado de trabalho.

Essa crítica se sustenta principalmente pela opção escolhida pelo MEC/CNE em utilizar o modelo de competências para assegurar níveis de qualidade na formação profissional. Sem dúvida, essa escolha encontra-se objetivada à essa finalidade. Entretanto, precisamos avaliar se todas as outras modificações em relação à formação e a estruturação curricular encontram-se meticulosamente articulada a esse fim. Ao que parece, o documento é contraditório e, ao mesmo tempo em que apresenta limites e vinculações explícitas ao sistema, expõe avanços significativos para a formação profissional brasileira. Em artigo escrito para a RBCE, o professor Nivaldo David, reconhece alguns avanços no currículo de formação profissional a partir do parecer 09/01 - CNE, embora questione nesse mesmo trabalho a adoção do conceito de competências como um aprisionamento legal profundamente vinculado ao projeto neoliberal. Assim, observa que,

...Não podemos desconhecer o lado positivo do Parecer 09/01-CNE, que determina a formação inicial de professores da educação básica em nível superior, nos cursos de licenciatura plena com terminalidade e identidade próprias. Tal perspectiva certamente se aproxima dos anseios históricos do movimento dos educadores no Brasil(...) Não podemos deixar de reconhecer que o princípio proposto para a intervenção sobre a realidade - no sentido da mudança - deva ocorrer através da pesquisa sobre a prática ou o fazer pedagógico a partir da prática concreta. Entendemos que o papel da didática/prática de ensino e do estágio supervisionado certamente oferecerá possibilidades importantes no processo de formação acadêmico-profissional (DAVID, 2002, p. 119-133).

Outro aspecto importante e que integra o conjunto das críticas endereçadas às diretrizes atuais, refere-se à divisão da formação profissional em Educação Física em licenciatura e bacharelado. Os argumentos que os pesquisadores declaradamente contrários à divisão da formação apresentam é que a divisão da formação profissional em Licenciatura e Bacharelado atende aos preceitos do novo ordenamento capitalista que, amparado pelo intervencionismo do Estado sobre o sistema produtivo, adota condições para a ampliação e maximização das taxas de lucros dos investidores capitalistas. No caso da Educação Física, vinculam o CONFEF, 
enquanto representante dos empreendedores dessa área profissional, como protagonista principal no processo de construção das novas diretrizes da área e da consequente divisão da formação profissional. Nessa mesma linha, atribui à Resolução CNE/CES nº 07/2004, o estigma de ter dividido a formação em Educação Física e se constituir como um documento ultraconservador, que irá contribuir para a formação de um profissional pragmático e executor de tarefas compatíveis com os interesses do mercado emergente da Educação Física (TAFFAREL, 2005; NOZAKI, 2006; VENTURA, 2010). Ainda questionam o fato de um mesmo currículo derivar duas formações diferentes, a licenciatura e o bacharelado (FARIA JR, 1992; VENTURA, 2010).

Aqui é importante observamos que é falaciosa a visão de que as Resoluções CNE/CP n ${ }^{\circ}$ 01 e 02/2002 e a Resolução CNE/CES nº 07/2004 são antagônicas e que provocaram a divisão da formação profissional em Educação Física. Na verdade elas se complementam na medida em que Resolução CNE/CES no 07/2004 apresenta os conhecimentos identificadores da área, objeto de intervenção pedagógica nas licenciaturas.

Ainda sobre a questão da divisão, independente da separação ou não dos cursos em licenciatura e bacharelado, a experiência de formação em Educação Física tem demonstrado que essa dicotomia no percurso formativo tem se dado, sobretudo, nas Licenciaturas ampliadas em que o aluno é formado para conhecer e atuar como docente tanto na escola como fora dela. Com raríssimas exceções, há divisão no processo de intervenção quando alunos são submetidos a experiências pedagógicas a partir de bases teórico-filosóficas diferentes. Há divisão em relação à produção de conhecimento nas experiências de pesquisa em que temas, bases teóricas e metodológicas mudam de acordo com os objetivos do trabalho e da orientação dos professores. Diante disso, acreditamos que a divisão acontece fundamentalmente pela dificuldade de conciliar bases epistemológicas do campo socio-educacional e da saúde que possuem lógicas operacionais diferentes. Talvez, a teoria de campos de Bourdieau seja apropriada para analisar essa situação, já que o modus operandi das áreas da saúde é diferente das áreas sociais e pedagógicas no que tange à produção e extensão do conhecimento.

Feitas essas reflexões, seguiremos mais detidamente em nossas análises, identificando que as pesquisas e os estudos atuais sobre as experiências em desenvolvimento, reconhecem limites na atual legislação, porém, identificam significativos avanços. Avaliando os periódicos, encontramos artigos em que os seus responsáveis se dedicaram a produzir e avaliar experiências curriculares em suas universidades.

Nesse sentido, nos apresentam dados que se constituem como dificuldades no processo de formação, mas que são externos ao currículo como as representações sociais dos alunos em 
torno da formação e outros dados que, em nossa opinião, não se constituem em problemas da formação, ao contrário, são possibilidades de avanço proporcionadas pelo novo marco regulatório da Educação Física e já postas em ação em seus espaços formativos. Assim podemos resumir os limites e as possibilidades dessa nova perspectiva curricular: Influência das experiências sócio-corporais na formação do professor de Educação Física; Necessidade da construção do saber docente apoiado em práticas dialógicas que favoreçam a compreensão do saber-fazer escolar; Flexibilização curricular e a necessidade de "articulação" entre teoria e prática nos cursos de formação docente; Noção de currículo como prática; Professor sujeito ativo de suas práticas; Possibilidades curriculares, tempos e espaços, pensados para trabalhar o sentimento de formar-se professor.

Com referência às experiências sócio-corporais, na formação do professor de Educação Física aparece como um dado externo, próprio ao currículo vivido ou de quem está pesquisando a prática curricular. Trata-se das representações dos alunos em torno do significado da formação em Educação Física, em geral, apreendido pelas suas experiências corporais no esporte, lutas, dança etc. Nesse sentido, faz-se importante organizar a formação de modo a compreender e contemplar as experiências sociais do aluno do curso de Educação Física não apenas como forma de interação entre a cultura de origem e a cultura de formação, mas, também, como uma maneira de intervir e romper com algumas concepções incorporadas e transferidas para os cursos de formação.

Outras duas questões que fazem parte das preocupações dos pesquisadores seria a "necessidade da construção do saber docente apoiado em práticas dialógicas que favoreçam a compreensão do saber-fazer escolar e o professor sujeito ativo de suas práticas". Sobre esses aspectos, Paiva et ali (2006) enfoca dois pontos: o primeiro deles se refere às discussões relativas à formação do professor - de educação física - para atuar na educação básica. $\mathrm{O}$ segundo sobre a perspectiva da construção do saber docente apoiado em práticas dialógicas que favoreçam a compreensão do saber-fazer escolar. A partir dessa compreensão sugere-se "currículos com disciplinas curriculares obrigatórias, perspectivadas na e com atitude dialógica contemplando os conhecimentos da Formação Comum e do Conhecimento da Área" (Idem, 2006, p. 213-230).

Temos também como questões, "a flexibilização curricular e a necessidade de articulação entre teoria e prática nos cursos de formação docente; e possibilidades curriculares, tempos e espaços, pensados para trabalhar o sentimento de formar-se professor". A antiga estrutura linear dos currículos com disciplinas estanques e a fragmentação do conhecimento pode ser rompida a partir da flexibilidade curricular que nada mais é que a possibilidade de 
estruturação e articulação do conhecimento em atividades disciplinares ou com outras configurações, em sala de aula ou em outros espaços, que permitam aos alunos uma apreensão mais aprofundada, atualizada e contextualizada do conhecimento. Assim é possível apresentar outras formas para construção e experimentação do conhecimento necessário à formação de professores de educação física como: seminários de estudo para introdução e/ou aprofundamento de determinado tema, seminários articuladores das disciplinas curriculares de cada semestre do curso, oficinas e outros projetos e atividades que integram os conhecimentos advindos da experiência e de cultura geral e profissional.

Por fim, temos a "noção de currículo como prática". Esse ponto representa um desafio para o conjunto dos professores que participam da formação profissional no interior dos espaços formativos. Para Figueiredo, a noção de currículo como prática indica duas ideias:

...uma, de que o conceito de currículo está relacionado com enfoques paradigmáticos diferentes, e outra, de que esses enfoques têm uma relação estreita com o contexto de produção do currículo. Visto assim, o currículo não deve ser reduzido à aparente separação entre o escrito e o vivido, mas do prescrito ao vivido e avaliado, considerando todas as complexidades que envolvem o desenvolvimento curricular. (2009, p. 1-11)

Nessa perspectiva, é possível vivenciar e refletir sobre os conhecimentos em contato com o contexto real em que eles foram produzidos. Portanto, o processo formativo será resultante dessa dinâmica em que se compreende o currículo como uma prática social e não como uma lista de disciplinas que precisam ser cursadas e que vão cumulativamente adensando o conhecimento do aluno. Aparecem também, a partir dessa opção metodológica, a possibilidade da contradição, da identificação da provisoriedade do conhecimento e tantas outras possibilidades no campo formativo. Por fim e para além da análise identificada nos artigos consultados, vale a pena destacar alguns aspectos que, para nós, constituem-se como avanços no atual modelo formativo.

$\mathrm{O}$ conceito de currículo integrado é um desses avanços que podemos mencionar. Durante várias décadas, especialmente as do final do século $\mathrm{XX}$, foram denunciadas como principal obstáculo à compreensão crítica da prática pedagógica a dicotomia entre a teoria e a prática. Embora, com viés neoliberal, as possibilidades que se abrem no currículo visando proporcionar a unidade entre teoria e prática, representa um grande avanço na estrutura e organização curricular dos cursos de graduação.

As diretrizes também reafirmam a autonomia das Universidades no processo de elaboração das propostas curriculares, já conferida pela antiga Resolução CFE nº 03/87 o que, 
em si, representa um grande avanço.Entretanto, é importante questionarmos que, ao mesmo tempo em que se propõe autonomia às IES para formularem os seus currículos, também se adota uma política de avaliação e fiscalização por intermédio do MEC visando assegurar o cumprimento de determinadas normas.

Quanto à crítica do pragmatismo na formação, podemos questionar a validade dessa insistente tese de que a competência incorporada ao processo de formação profissional irá determinar a gestação de um "professor-pragmático", limitado apenas às situações-problemas detectadas em suas experiências imediatas, normalmente, descontextualizadas com a sua realidade social.

A possibilidade de o aluno ser formado em contato com a prática desde o início do curso, para além das análises que vinculam à prática ao saber fazer, revela-se como um avanço no processo formativo, e fez também parte das reivindicações dos pesquisadores da Educação Física durante toda a década que antecedeu a construção das diretrizes. Não está explícito e nem é imperativo nas diretrizes a qualidade dessa experiência.

Esse modelo rompe, também, com a dicotomia histórica nos cursos de graduação entre teoria e prática no momento em que determina a prática e a pesquisa como elementos essenciais e indissociáveis na formação profissional. Isso se materializa com a adoção da prática desde o início do curso e, especialmente, com os estágios supervisionados iniciando-se a partir da metade do curso. Além disso, estabelece a pesquisa como eixo fundamental de conhecimento da realidade objetiva que envolve as relações sociais, sobretudo no mundo do trabalho, mediatizada pela teoria, com vistas à sua interpretação crítica.

A fim de corroborar com as nossas reflexões, gostaríamos de apresentar a seguinte observação a respeito das possibilidades emanadas pelo Parecer CNE/CP 09/01, que foi transformado na Resolução 01/02 que apresenta diretrizes para a construção dos currículos de formação de professores em geral:

No que se refere à organização da matriz curricular, esse Parecer indica as seguintes diretrizes para as IES: pensar formas inovadoras de organização dos conhecimentos para além da organização em disciplinas; promover atividades coletivas e interativas de comunicação entre os professores em formação e os professores formadores; incentivar estudos disciplinares que possibilitem a inter-relação entre os conhecimentos mobilizados na formação; articular a formação comum com a formação específica; articular os conhecimentos educacionais e pedagógicos com os conhecimentos de formação específica; e articular teoria e prática desde o início da formação (PAIVA et ali, 2006, p. 213-230). 
Sobre o parecer 058/04, Paiva el ali (2006) indica que a referida norma não restringe a caracterização da área à sua dimensão biológica no campo da saúde, permitindo às IES a base epistemológica que irá orientar seus currículos de formação em Educação Física.

Portanto, o objetivo dessa reflexão sobre as diretrizes curriculares foi avaliar os seus desdobramentos sobre a formação profissional em Educação Física, na tentativa de destacar aspectos que não são comumente avaliados em grande parte da produção científica da área. Talvez, o contexto de reformas acontecidas no final do século $\mathrm{XX}$, num declarado aceno à política neoliberal, tenha nos impedido de reconhecer determinados avanços nas atuais diretrizes curriculares. Entretanto, diante do que levantamos em termos de problemáticas nos cursos de formação antes da aprovação da atual legislação é possível identificar avanços a partir das suas orientações curriculares.

Assim finalizamos esse capítulo, por meio do qual pretendíamos abordar essa complexa discussão sobre as diretrizes curriculares, seus limites, mas, também, os seus avanços. Há dez anos em vigor, vêm normatizando a construção dos currículos de formação em nossa área e devemos encontrar saídas para uma formação mais humana e crítica a partir delas. Entendemos, por meio dos nossos estudos, que a negação e a repulsa a esses documentos legais, a partir de postulados ideopolíticos, não contribuem para avançarmos em proposições progressistas. Existem margens para outras interpretações e cabe aos agentes que participam da formação atuarem e exercerem a autonomia que lhes é conferida no processo de construção e operacionalização de currículos realmente avançados.

Embora tenhamos refletido de uma maneira mais ampla sobre o processo de constituição histórica das diretrizes e também dos pressupostos fundamentais do nosso trabalho, no próximo capítulo vamos demonstrar os dados da pesquisa sobre o currículo e a produção de conhecimento do curso de Educação Física da UNEB de Guanambi-BA com o objetivo de identificar os seus limites e avanços. Além disso, esperamos encontrar nexos e contradições entre o modelo preconizado por esse curso e os discursos do campo legal e acadêmico atribuídos às atuais diretrizes curriculares da Educação Física. 


\section{CAPÍTULO 3 - EDUCAÇÃO FÍSICA E HIBRIDISMO CURRICULAR: O CURSO DA UNEB DE GUANAMBI - BA}

Iniciamos o nosso trabalho analisando o percurso histórico da formação em Educação Física e percebemos como os currículos foram se modificando a partir das condições sociais, econômicas, culturais e políticas. Em seguida, refletimos mais especificamente sobre o processo de constituição histórica das diretrizes curriculares de formação em Educação Física, tanto na licenciatura como na graduação/bacharelado. É importante ressaltar que esse estudo levou em conta a cena política e econômica do final do século XX e início do século XXI no Brasil oferecendo-nos, desse modo, oportunidade para identificarmos contradições, limites e possibilidade das normas legais. Agora, passaremos a partir desse ponto em nosso trabalho, a analisar a prática curricular, ou seja, como os discursos vêm sendo materializados nos espaços formativos da Educação Física, em especial o da universidade.

Aqui nos importa analisar a experiência dos coletivos envolvidos na formação profissional da Educação Física, avaliando como esses atores sociais vêm interpretando as novas diretrizes curriculares e, a partir delas, construindo e executando os projetos curriculares e as alternativas pedagógicas vinculadas a formação dos novos professores.

Após dez anos de vigência, as diretrizes curriculares da Educação Física expressas nas Resoluções CNE/CP 01 e 02/2002(Licenciatura) e Resolução CNE/CES 07/2004(Graduação), orientam a construção e a execução dos currículos dos cursos nas instituições vinculadas à formação profissional.

No âmbito acadêmico como tivemos oportunidade de analisar, parece ainda não haver acordo em torno da legitimidade dessas normas. Enquanto um grupo de pesquisadores denunciam o seu caratér pragmático, outros ressaltam as possibilidades advindas dos avanços na estrutura e funcionalidade curricular.

Nesse trabalho, embora reconheçamos que as atuais diretrizes, ao fim e ao cabo, direcionam o processo avaliativo e se configuram como um marco orientador de políticas públicas apontamos, também, possibilidades pedagógicas a partir delas. Compreendemos que as diretrizes apresentam orientações que dão margem à construção de currículos voltados para uma formação humana, dialógica e crítica.

Dessa forma, o nosso propósito nesse capítulo será analisar a experiência de produção e execução curricular por parte de professores do curso de Educação Física da UNEB - Campus XII no município de Guanambi. 


\section{1 - Delineando o espaço da pesquisa}

O nosso trabalho será realizado na Universidade do Estado da Bahia (UNEB) que é a maior instituição pública de ensino superior da Bahia. Fundada em 1983, está presente geograficamente em todas as regiões do Estado, sendo estruturada no sistema multicampi. A UNEB possui 29 Departamentos instalados em 24 campi, um sediado na capital do estado, onde se localiza a administração central da instituição, e os demais distribuídos em 23 importantes municípios baianos de médio e grande porte.

O Departamento de Educação da UNEB-Campus XII está localizado no município de Guanambi - BA e foi criado inicialmente como Faculdade de Educação de Guanambi (FAEG) pelo Decreto n 2.636 em 04 de agosto de 1989, publicado no Diário Oficial do Estado da Bahia de 05 e 06 de junho de 1989. Em 1997, em função da Lei de $n^{\circ} 7.176$ que dispõe sobre a reestruturação das Universidades Estaduais da Bahia, a UNEB adotou a estrutura de Departamento de Educação - DEDC Campus XII.

Guanambi é considerada uma cidade de médio porte e está localizada no sudoeste Baiano, a 796 km de salvador. Está a 525 metros de altitude acima do nível do mar, com uma área de 1.302.799 km2 (IBGE, 2009). O relevo é pouco acidentado, mais parecendo uma planície, cercada por desníveis considerados isolados, entre os quais a Serra do Espinhaço, no limite com Caetité. As terras são cortadas pelos rios Carnaíba de Dentro e Carnaíba de Fora, ambos afluentes do Rio das Rãs, que por sua vez é afluente do Rio São Francisco.

Seu clima é basicamente semiárido, com temperatura média anual de $22,6^{\circ} \mathrm{C}$. O período da chuva se dá entre os meses de setembro a março. Seu relevo caracteriza-se pela presença do Pediplano Sertanejo, das superfícies dos Gerais e do Planalto do Espinhaço. A vegetação predominante é do tipo rasteira, o solo é vermelho-amarelo distrófico, encontrado na região.

Quanto a seu aspecto demográfico, não difere dos demais centros urbanos da Bahia onde se verifica um crescimento notável da população urbana, enquanto apresenta um decrescimento da população rural. A atual população de Guanambi apresenta uma estimativa 78.801 mil habitantes, segundo dados do IBGE/2010.

Este município apresenta também um índice de Desenvolvimento Humano (IDH) de 0,701 PNUD/2000 e um PIB per capita de R \$ 5.842,79 IBGE/2010. Embora esteja numa posição razoável na classificação do IDH, os seus índices educacionais sempre demandaram ações que pudessem atingir um maior contingente da população.

Cidade polo do extenso e populoso Estado da Bahia, Guanambi, nas últimas décadas, se tornou um médio centro comercial da região, atraindo pessoas com necessidades diversas, entre 
elas, a de melhor qualificação profissional. No campo da educação, esta necessidade torna-se ainda mais evidente se considerado os diversos estabelecimentos de ensino, sem profissionais com formação adequada às diversas áreas.

A partir do final da década de 80, Guanambi passou a se destacar como polo educacional, atraindo estudantes de diversas regiões, em função da chegada da instituição de ensino superior. Neste cenário, a FAEG em 1991, ofereceu a primeira turma do curso de Licenciatura Plena em Pedagogia, nas Habilitações Magistério das Matérias Pedagógicas do $2^{\circ}$ Grau e Magistério para as classes de Alfabetização, reconhecidas pelo Decreto Estadual $n^{\circ}$ 7.528/99 publicado no Diário Oficial de 19.02.1999.

Em 1998 foi aprovado o curso de Educação Física junto às instâncias do CONSEPE/CONSU da UNEB. Sua implantação se deu no ano de 1999 tendo como suporte legal a Resolução CFE No 03/87. Em 2003 passou, a exemplo de todas as licenciaturas da UNEB por um processo de redimensionamento, adequando-se às Resoluções CNE/CP No $01 \mathrm{e}$ 02/2002 e, na ausência da nova diretriz específica da Educação Física, utilizou a vigente à época, a Resolução CFE No 03/87. Hoje o Departamento de Educação de Guanambi oferece os seguintes cursos: Licenciatura em Pedagogia e Educação Física e Bacharelado em Enfermagem e Administração. Além desses são oferecidos os cursos de Licenciatura em Educação Física, Pedagogia, Letras e Artes, integrantes do Programa Especial de Formação Plataforma Freire (PARFOR); Matemática e Geografia do Programa de Formação para Professores do Estado/ PROESP.

A estrutura física do DEDC XII é formada por 11 salas de aulas, laboratórios de informática, laboratório de enfermagem, quadra poliesportiva coberta, piscina semiolímpica, campo de futebol, pista de atletismo, biblioteca, auditório, centro de pesquisa e extensão e área administrativo-financeira.

O corpo docente é composto por 04 professores doutores, 21 professores mestres e 33 professores especialistas sendo 44 efetivos e os demais substitutos. Entretanto, dependendo da necessidade de cada curso e semestre, outros professores colaboradores são convidados pelo DEDC XII. O corpo discente do Campus XII é composto por 1.065 alunos, sendo 224 de Administração, 256 de Educação Física, 144 de Enfermagem e 441 de Pedagogia. O corpo técnico administrativo é formado por 21 funcionários entre efetivos e contratados.

O curso de Educação Física do Departamento de Educação - Campus XII da UNEB funciona em período diurno, oferecendo 50 vagas anuais. A sua integralização curricular é feita num tempo mínimo de 4 anos e máximo de 7 anos. 


\subsection{1 - caracterizando o estudo empírico}

Quanto à finalidade, esse estudo se caracteriza como uma pesquisa descritiva que, segundo Duarte e Furtado (2002) tem como objetivo principal descrever características de determinada população, ou fenômeno, ou então o estabelecimento de relações entre variáveis e, em alguns casos, a natureza dessas relações.

Com relação aos procedimentos técnicos, o estudo pode ser delineado como uma pesquisa documental que para Gil (2008), se caracteriza pela escolha de materiais que não receberam ainda um tratamento analítico, ou que ainda podem ser reelaborados de acordo com os objetos da pesquisa. Além de analisar os documentos de "primeira mão" (documentos de arquivos, igrejas, sindicatos, instituições etc.), existem também aqueles que já foram processados, mas podem receber outras interpretações, como relatórios de empresas, tabelas etc. Em nosso estudo utilizaremos os documentos de "primeira mão" como as Resoluções que tratam das diretrizes curriculares da área da Educação Física, além do projeto de Redimensionamento do Curso de Educação Física da UNEB - Campus XII, que teve como objetivo adequar o projeto original do curso às normas atuais. Utilizaremos também como fonte de pesquisa documental os Trabalhos de Conclusão de Curso (TCC) dos formandos no período de 2008 a 2013. A análise dos dados foi feita pela técnica da análise de conteúdo que, para Bardin apud Triviños, (2006, p. 160) é

\footnotetext{
"um conjunto de técnicas de análise das comunicações, visando, por procedimentos sistemáticos e objetivos de descrição do conteúdo das mensagens, obter indicadores quantitativos ou não, que permitam a inferência de conhecimentos relativos às condições de produção/recepção (variáveis inferidas) das mensagens".
}

A análise dos dados, a interpretação, as significações, relações e contradições das mensagens redigidas nesses documentos em comparação com os discursos sobre formação profissional em Educação Física, tanto no campo legal como acadêmico, constituiu-se no principal foco desse estudo.

Em relação ao projeto de redimensionamento do curso de Educação Física em pauta, definimos as seguintes categorias para a análise: Justificativa curricular; Concepções, finalidade e objetivos do curso; Perfil profissiográfico; Habilidades e competências; Estrutura e dinâmica curricular; Disciplinas ou componentes integrantes do currículo; Bases epistemológicas e pedagógicas das disciplinas e/ou componentes curriculares; Análise do referencial bibliográfico; Configuração da matriz curricular; Abordagem metodológica do curso. 
Ressaltamos que a definição das respectivas categorias foi feita a partir da estrutura do projeto de redimensionamento do curso e pelo que representam em termos da concepção, organização, estrutura e funcionalidade do curso.

\subsection{2 - Supostos à proposta curricular}

Antes de proceder a análise das categorias selecionadas para o estudo, gostaríamos de refletir sobre um suposto inicial, de que há uma condição de hibridismo curricular que vem se materializando na formação profissional em Educação Física já há bastante tempo. Isso se confirma pela junção ou integração de conhecimentos de bases epistemológicas diferenciadas e, também, de culturas acadêmico-científicas desconexas.

Segundo Dussel (2002), é possível encontrar discursos híbridos na educação desde a emergência da escola pública. A própria noção de currículo pode ser considerada como um híbrido, ou seja, um resultado de um processo que seleciona a cultura e a traduz a um ambiente e uma audiência particulares. Os discursos curriculares também são híbridos que combinam distintas tradições e movimentos disciplinares, construindo coalizões que dão lugar a determinados consensos.

Concordamos ainda com Dussel (2002) em que analisar o currículo, em termos da hibridação que o constitui, oferece novas possibilidades para se refletir sobre a complexidade dos processos culturais, políticos e sociais que o configuram, em vista das novas ideias que podem advir para esse campo de conhecimento.

O conceito de hibridismo permite vislumbrar novas perspectivas de análise para a compreensão dos processos de reconhecimento, de legitimação, de interpretação e de apropriação das políticas curriculares nas diferentes instâncias pelas quais transitam até à sua efetiva implementação na instância da prática. É preciso considerar, entretanto, que sua utilização oferece oportunidades, riscos, ambivalências e possibilidades. Oportunidades porque os embates entre grupos e sujeitos que o processo de hibridação envolve, podem oferecer ocasiões para explorar a gama de possibilidades que se expressam na cultura e na história, e porque a negociação de sentidos e de significados que constitui essa produção pode engendrar a emergência de novas alternativas, além de lidar com a diversidade, que é uma necessidade no sentido de uma cultura cívica democrática (BURBULES, 2003). Riscos porque pode provocar compreensões equivocadas e ambivalências, considerada a polissemia que envolve o termo, ou mesmo entendendo e atribuindo à produção híbrida um alcance que extrapole a sua configuração conceitual na teoria contemporânea. Como enfatiza Dussel (2002), se o 
hibridismo provê uma estratégia de luta significativa contra todo tipo de essencialismo, também corre o risco de obscurecer a profunda desigualdade que segue existindo em nossa sociedade.

Portanto, o suposto é que o currículo do curso de Educação Física da UNEB - Campus XII e, não só ele, constitui-se como um híbrido curricular, se dando, essencialmente, pela conciliação de discursos teóricos e de conhecimentos tácitos no processo de materialização do projeto curricular. Invariavelmente, é possível identificar seja na prática pedagógica dos professores nos cursos de formação, seja na produção acadêmica dos acadêmicos a junção/fusão de teorias para se explicar ou intervir sobre a realidade objetiva da Educação Física.

Esse pensar e agir expresso nas produções advindas de trabalhos de Iniciação Científica, Relatórios de Estágio, Trabalhos de Conclusão de Curso, etc, relaciona-se com o processo de formação profissional e com a sua estrutura curricular moldada sobre bases epistemológicas diferenciadas e, numa espécie de "união instável", que se desagrega, se modifica e se adapta às diversas necessidades interpretativas da realidade, porém, de maneira parcial, limitada e difusa.

A teoria, nessa perspectiva, mais parece uma "alegoria" que é utilizada muito mais para atender às exigências "cientificistas" do trabalho acadêmico, do que como um arsenal explicativo da realidade. As estruturas curriculares em vigor na Educação Física, sejam elas licenciatura ampliada ou bacharelado, tem se caracterizado dessa forma, a partir do momento em que integram, reinterpretam e traduzem as teorias, subordinando-as ao objeto estudado e, consequentemente, à lógica instrumentalizadora do mercado. Assim, ao analisarmos o projeto do curso e a produção do conhecimento a partir dos TCCs, tentaremos, dentre outros aspectos, analisar a existência no currículo do curso de Educação Física da UNEB - Campus XII, de uma condição híbrida que repercuta na formação dos acadêmicos.

Além do hibridismo curricular, apresentamos mais algumas hipóteses de trabalho a serem investigadas:

- O currículo se mostra contraditório, às vezes avançando criticamente em relação às competências e perfil profissiográfico, às vezes se adequando às normas;

- Em virtude do seu hibridismo, não existe uma referência teórica predominante ou hegemônica que embase o processo de formação profissional;

- Não existe um projeto que oriente as ações político-pedagógicas no processo formativo;

- Parece existir uma contradição no campo legal entre o modelo curricular do curso, ou seja, uma licenciatura ampliada e as diretrizes curriculares atuais para a formação em Educação Física; 
- O currículo se estrutura, se organiza e se molda com vistas ao atendimento do mercado de trabalho escolar e não escolar;

- O curso é uma licenciatura, mas não oferece conhecimentos no campo teórico e metodológico suficientes para atuar na Educação Básica contrariando os marcos legais que o embasaram;

- Embora com o discurso da unificação das áreas de atuação profissional, por dentro, o curso se divide e se desarticula em relação ao ensino, pesquisa e extensão. Ao mesmo tempo em que propõe um discurso integrador, expõe profundas contradições em sua prática curricular;

- O curso avança em sua estrutura e funcionalidade, ou seja, a ideia da flexibilidade curricular preconizada pela Resolução CNE/CP N N $^{\circ}$ 1/2002, possibilita a estruturação de atividades capazes de produzir o diálogo acadêmico e o conhecimento da realidade, muito embora esteja preso ao processo histórico de fragmentação da área;

- Existe uma divisão e fragmentação em relação à prática de ensino (estágios supervisionados) na medida em que os divide em estágios escolar e não-escolar, com adoção de bases teóricas e metodológicas diferenciadas para o processo de intervenção;

- A divisão por dentro, repercute fortemente na produção de conhecimento que, invariavelmente, ocorre de maneira fragmentada e descontextualizada;

- Há uma hegemonia da área de saúde no interior do curso em virtude das representações sociais que consideram os profissionais da área da saúde mais valorizados em detrimento da educação. Supomos também que, em relação ao curso da UNEB-Campus XII, a hegemonia se consolida também pelo pragmatismo dos profissionais vinculados a essa atuação no interior do curso.

Portanto, passemos então a apresentar e analisar os dados referentes ao projeto curricular na tentativa de validar ou não as hipóteses supracitadas, além de tentar trazer outros elementos reflexivos oriundos do processo investigativo. 


\section{2 - O projeto curricular do Curso de Educação Física da Uneb - Campus XII - Guanambi-BA}

Após a publicação das Resoluções CNE/CP nº 01 e 02 em 18 e 19 de fevereiro no ano de 2002 e, atendendo o Art. $15^{30}$ da primeira resolução, a gestão da UNEB, com o intuito de adequar legalmente os cursos de Licenciatura, uma vez que a universidade encontrava-se em processo de recredenciamento pelo CNE, expediu a Portaria n ${ }^{\circ}$ 1444/2003 "criando a Comissão de Reformulação dos Currículos dos Cursos de Formação de Professores no âmbito da UNEB passando pela organização de Oficinas para o debate do tema, culminando com a apresentação de propostas"(UNEB, 2003, p. 5). É importante ressaltar que, cercado pelas circunstâncias administrativas e legais, as comissões, compostas geralmente pelos Coordenadores dos Cursos, tiveram que desenvolver o trabalho num tempo relativamente curto acarretando prejuízos na qualidade dos projetos. Aliado a isso, a UNEB contratou uma consultora para orientar os trabalhos de todas as comissões, sendo que alguns cursos ficaram prejudicados pelo fato da consultora, que tinha formação em Artes, não dominar aspectos do campo teórico-metodológico das áreas profissionalizantes e, consequentemente, não contribuindo tanto para a qualificação das propostas.

Nessa época, existiam dois cursos de Educação Física na UNEB, o do Campus XII em Guanambi e o do Campus IV em Jacobina, tendo sido a comissão composta pelos Coordenadores dos dois Cursos, os professores Osaná Macedo Reis (Campus XII) e o professor Salomão Cleômenes Lima Costa (Campus IV) além de representante de professores e alunos.

Já na apresentação do projeto, conseguimos identificar dados que demonstram a sua vinculação com a lógica das Reformas Curriculares, qual seja, a do paradigma da racionalidade técnica, objetivada na constituição de competências ao longo do processo de formação. Embora caminhando nessa lógica, é possível identificar contradições no interior do projeto ao apresentar sinalizações voltadas para uma formação mais humana e crítica, ressaltando bem a sua condição de híbrido curricular.

O objetivo deste trabalho é apresentar uma proposta que possa oferecer uma matriz curricular capaz de construir um perfil acadêmico e profissional com competências, habilidades e conteúdos, dentro de perspectivas e abordagens contemporâneas de formação pertinentes e compatíveis com referenciais nacionais e internacionais, capazes de atuar com qualidade, eficiência e

\footnotetext{
${ }^{30}$ Os cursos de formação de professores para a educação básica que se encontrarem em funcionamento deverão se adaptar à esta Resolução do CNE no prazo de dois anos.(Brasil, 2002)
} 
resolutividade, conforme prevê as Diretrizes Curriculares Nacionais do Curso de Graduação em Educação Física, (grifos nossos) além de atender as especificidades locais, as características de uma instituição multicampi como a UNEB e a legislação vigente(UNEB - Campus XII, 2004, p. 5)

Feito as observações em relação aos aspectos históricos constitutivos do processo de reformulação dos cursos no âmbito da UNEB, passaremos, conforme anunciamos anteriormente, à análise do projeto de Redimensionamento ${ }^{31}$ do Curso de Licenciatura em Educação Física do Departamento de Educação - Campus XII a partir de categorias pertencentes ao esquema organizativo do projeto e também por expressarem, em conjunto, a proposta curricular.

Com isso, temos as seguintes categorias: Justificativa curricular; Concepções, finalidade e objetivos do curso; Perfil profissiográfico; Habilidades e competências; Estrutura curricular e abordagem metodológica do curso; Formas de Avaliação; Análise do Ementário do Curso; Análise do referencial bibliográfico.

\subsection{1 - Justificativa curricular}

Essa categoria é bastante importante no conjunto das nossas análises em virtude de apresentar as bases legais, por meio da qual o projeto foi concebido. Além disso, discute a perspectiva curricular do curso a partir da necessidade histórica de revisão paradigmática dos currículos de formação profissional no Brasil.

Assim, defende a substituição do termo "grade curricular" comumente usado para designar o currículo dos cursos mais antigos, pelo termo "matriz curricular". Explica que "a opção pelo uso da expressão 'matriz curricular' aponta para o conceito de Currículo para além da listagem de conteúdos, do saber 'atrás das grades', evidenciando a perspectiva de um currículo não-linear"'(UNEB, 2004, p. 9).

Nessa perspectiva, defende um currículo construído a partir dos seguintes princípios:

Trabalho pedagógico escolar como princípio educativo que norteia o desenvolvimento da proposta curricular; A prática da interdisciplinaridade como princípio para o desenvolvimento de um trabalho que articule os conteúdos das diversas áreas de estudo em torno de questões centrais e/ou que garanta a observância do princípio definido; A pesquisa como princípio cognitivo e instrumentalizador do trabalho

\footnotetext{
${ }^{31} \mathrm{O}$ termo Redimensionamento atribuído ao projeto do curso se deu em função do seu objetivo primordial que era o de redimensionar o antigo projeto de Reconhecimento do Curso.
} 
docente; A indissociabilidade entre a teoria e a prática; Consideração/observância das especificidades (tempo, espaço, interação professor/aluno, tutor/aluno, professor/tutor...) que caracterizam e diferenciam a modalidade à distância da presencial no sentido de maximizar o desenvolvimento do curso, construindo/reconstruindo a metodologia no processo educativo(UNEB - Campus XII, 2004, p. 9)

É importante refletirmos sobre esses princípios, pois é exatamente a partir deles que a prática formativa se alicerça. A primeira relaciona-se com o Artigo $3^{\circ}$ da Resolução CNE/CP $n^{\circ}$ 01/2002 que estabelece princípios para nortear a construção dos currículos de formação. Observamos que apenas dois princípios da Resolução foram seguidos pela comissão responsável. O Inciso II que estabelece o princípio da coerência entre a formação oferecida e a prática esperada do futuro professor (Brasil, 2002) que, em nossa opinião, é análogo ao princípio do trabalho pedagógico escolar presente na proposta e o Inciso III que estabelece a pesquisa, com foco no processo de ensino e de aprendizagem, uma vez que ensinar requer tanto dispor de conhecimentos e mobilizá-los para a ação, como compreender o processo de construção do conhecimento (Ibidem, 2002), também análogo à proposta em que valoriza a pesquisa como princípio cognitivo e instrumentalizador do trabalho docente.

É no mínimo curioso o fato do Inciso I do Art. $3^{\circ}$ da Resolução não ter sido utilizado no projeto, uma vez que é ele quem expressa a "competência como concepção nuclear na orientação do curso.”(Ibidem, 2002). Entretanto, das competências enquanto princípio da proposta curricular, parece ter sido um esquecimento,uma vez que tais competências aparecem em outros pontos do projeto, inclusive como uma categoria a ser analisada.

Analisando os princípios da proposta, temos "o trabalho pedagógico escolar" como elemento norteador da formação nos oferecendo grandes possibilidades de reflexão e inferência sobre o processo formativo. Primeiro que, a partir desse princípio, as aprendizagens ao longo da formação precisam ser associadas à realidade escolar, ou à realidade da prática pedagógica escolar dos futuros professores. Essa assertiva se relaciona com o conceito da simetria invertida preconizada pela Resolução CNE/CP n 01/02, em que a aprendizagem só será significativa quando apresentar nexos com o ambiente da intervenção pedagógica do professor, assunto já discutido nesse trabalho.

Por outro lado, em virtude de ser um curso de licenciatura e, portanto, que forma professores para atuar na Educação, elege a escola como foco preponderante da ação pedagógica dos futuros professores o que, em nossa opinião, parece ser fundamental numa proposta curricular qualificada, haja vista a ausência desse princípio nos modelos curriculares 
da Educação Física que, nos últimos tempos, vêm se preocupando muito mais com o atendimento das demandas do mercado de trabalho (BETTI, 1991, MOLINA, 1998).

A prática da interdisciplinaridade no processo de articulação e integração dos conteúdos e das experiências pedagógicas é outro princípio importante nessa proposta. Identificamos em nosso estudo as principais críticas/reivindicações aos currículos anteriores e às atuais normas, a ausência da interdisciplinaridade nos currículos e, em contraponto, a presença de currículos disciplinares, fragmentados, etc.(BÁSSOLI, 1995). Portanto, consideramos a adoção desse princípio, em que pese os obstáculos para a sua operacionalização, um grande avanço numa proposta curricular.

A pesquisa como princípio cognitivo e instrumentalizador do trabalho docente é mais um princípio que faz avançar o currículo na medida em que desenvolve o espírito crítico do aluno ajudando-o a pensar racional e cientificamente sobre os dados inerentes à sua prática social.

A indissociabilidade entre teoria e a prática como elemento essencial na construção da práxis pedagógica, do desenvolvimento do pensamento dialético e da capacidade de contextualização dos fenômenos sociais. Historicamente, não só na Educação Física como também em outras áreas, a dicotomia teoria e prática no currículo de formação esteve presente por vários aspectos. Ao analisarmos a prática do estágio supervisionado nos currículos mais antigos, percebemos que esse só era realizado no último ano do curso, ou seja, havia um tempo para teorizar e outro para praticar. Também percebemos essa dicotomia no cotidiano dos cursos quando se trabalha com uma teoria dissociada da prática. Nesse caso, a teoria não cumpre o seu papel essencial que é explicar a prática social. Mas, nem por isso, devemos achar que há uma supremacia da teoria sobre a prática, porque teoria e prática se misturam e se complementam num todo dialético, completamente instável e sujeito a modificações a partir das múltiplas determinações físicas e sociais. Autores como Rodrigues (1998), Rangel-Betti e Galvão (2001) e Molina (1998) criticaram os currículos organizados por meio da Resolução 03/87 pelo fato de apresentarem acentuada dicotomia entre teoria e a prática.

Por último a consideração e observância das especificidades como o tempo, espaço, a interação professor/aluno, tutor/aluno, professor/tutor promovendo a construção e reconstrução da metodologia no processo educativo. Consideramos importante essa ideia pois tem a ver com a noção do currículo enquanto prática, em que seus agentes, professores, alunos e gestores constroem dialeticamente ( FIGUEIREDO e MARQUES, 2009). 
Além dos princípios sobre os quais o currículo do curso de Educação Física da UNEB - Campus XII foi erigido, o projeto também firma uma perspectiva de formação como se segue:

Este projeto tenta avançar no sentido de assegurar uma formação que, tomando o trabalho pedagógico como princípio educativo e constitutivo da formação integral do professor, propicie ao mesmo tempo, um quadro técnico referencial de análise que lhe permita compreender o processo pedagógico em sua totalidade e complexidade, o processo de construção das ciências com as quais trabalha apreendendo a escola em suas relações com a sociedade mais ampla, podendo, a partir desses princípios, captar a dinâmica das atividades pedagógicas cotidianas, concebendo o currículo como um modo de organizar as práticas educativas, e, tendo em vista, a complexidade do fenômeno escolar, o Curso de Educação Física perseguirá os propósitos da qualidade do ensino, com as exigências de uma compreensão crítica que garanta aos professores a perfeita integração no processo coletivo da escola (UNEB - Campus XII, 2004, p. 9).

Assim, a perspectiva de formação do curso sugere o desenvolvimento do espírito crítico dos alunos, bem como de uma compreensão aprofundada e contextualizada em torno da realidade da escola e da educação. Com isso, reestrutura o currículo de formação quando “incorpora em sua matriz curricular com estrutura flexível, permitindo a atualização constante do conhecimento, organizada em dois núcleos: NÚCLEO DE FORMAÇÃO BÁSICA E NÚCLEO DE FORMAÇÃO PROFISSIONAL”(UNEB-Campus XII, 2004, p. 9).

Segundo a proposta, espera-se, com isso, garantir aos professores a perfeita integração no processo coletivo do espaço escolar e não escolar, contribuindo para a melhoria da qualidade do ensino e gerando possibilidades de intervenção e transformação do contexto social. (Ibdem, 2004, p.9).

Nesse ponto da justificativa, os autores da proposta tocam pela primeira vez no espaço de intervenção não escolar, entretanto, sem precisar ou definir melhor que espaço é esse. Parecem utilizar uma argumentação oriunda da formação de professores, sendo que buscam a integração dos professores aos processos coletivos desses dois espaços. Abordam também a questão da transformação do contexto social sem, porém, ter afirmado anteriormente o modelo de sociedade que esse projeto defende. Achamos essa observação importante, pois uma perspectiva crítica de formação só se justifica quando nos apoiamos em referenciais teóricos críticos. Assim, pensamos ser importante definir melhor na proposta curricular qual é a sua perspectiva teórico-filosófica para a formação dos professores.

Procurando detalhar melhor a estrutura da matriz curricular do curso, os autores da proposta a organizaram da seguinte forma: 


\section{I - NÚCLEO DE FORMAÇÃO BÁSICA}

$>1^{\circ}$ Bloco - Eixo Temático Articulador: Conhecimento e Identidade Profissional

$>2^{\circ}$ Bloco - Eixo Temático Articulador: Bases Epistemológicas da Educação Física

$>3^{\circ}$ Bloco - Eixo Temático Articulador: Conhecimento e Prática Pedagógica

$>4^{\circ}$ Bloco - Eixo Temático Articulador: Conhecimento e Prática Pedagógica

\section{II - NÚCLEOS DE FORMAÇÃO PROFISSIONAL}

$5^{\circ}$ Bloco - Eixo Temático Articulador: Bases para Produção do Conhecimento e Intervenção Pedagógica

$6^{\circ}$ Bloco - Eixo Temático Articulador: Bases para Produção do Conhecimento e Intervenção Pedagógica

$7^{\circ}$ Bloco - Eixo Temático Articulador: Atuação Profissional e Conhecimento Científico.

$8^{\circ}$ Bloco - Eixo Temático Articulador: Atuação Profissional e Conhecimento Científico.

Existe para cada bloco um componente articulador ${ }^{32}$ que até o quarto bloco se chamará PPP(Pesquisa e Prática Pedagógica) e do quinto ao oitavo se chamará PIEF (Pesquisa e Intervenção em Educação Física). Os eixos temáticos de cada bloco propiciarão a interação dos conhecimentos por meio de atividades de estudos e pesquisas que culminarão em seminários ou eventos interdisciplinares promovidos pelo professor do componente articulador em conjunto com os professores e alunos dos outros componentes curriculares (UNEB - Campus XII, 2004).

\footnotetext{
${ }^{32}$ Art. 11 da Resolução CNE/CP 01/02 - Os critérios de organização da matriz curricular, bem como a alocação de tempos e espaços curriculares se expressam em eixos em torno dos quais se articulam dimensões a serem contempladas, na forma a seguir indicada: I - eixo articulador dos diferentes âmbitos de conhecimento profissional; II - eixo articulador da interação e da comunicação, bem como do desenvolvimento da autonomia intelectual e profissional; III - eixo articulador entre disciplinaridade e interdisciplinaridade; IV - eixo articulador da formação comum com a formação específica; V - eixo articulador dos conhecimentos a serem ensinados e dos conhecimentos filosóficos, educacionais e pedagógicos que fundamentam a ação educativa; VI - eixo articulador das dimensões teóricas e práticas (Brasil, 2002).
} 
A estrutura e a dinâmica da matriz curricular do curso apresentam relação de coerência com os princípios anteriormente apresentados e discutidos. Assim, temos contemplado nesse modo de organização curricular, a prática, a pesquisa, a unidade entre teoria e prática e a interdisciplinaridade como possibilidades concretas no processo formativo. Também encontram-se contemplados outros aspectos anteriormente abordados nesse trabalho, como avanços relacionados às atuais diretrizes curriculares como o conhecimento da realidade de intervenção pedagógica do professor de Educação Física e o incentivo à reflexão na ação. Terminada a análise dos dados sobre a Justificativa Curricular do Curso, passaremos para a próxima categoria de análise.

\subsection{2 - Concepções, finalidades e objetivos do curso}

Ao analisarmos essa categoria, esperamos compreender melhor a concepção teóricofilosófica, finalidades e objetivos a que estão vinculadas a formação profissional do curso. Os autores iniciam com o objetivo da formação profissional.

O curso de Educação Física instalado no Departamento de Educação Campus XII da UNEB tem como objetivo a formação de um profissional capaz de contribuir, efetivamente, para a melhoria das condições em que se desenvolve a Educação e a Educação Física, e, consequentemente, comprometido com um projeto de transformação social.(UNEB - Campus XII, 2004, p. 12)

Percebe-se a partir desse enunciado, que a formação em Educação Física tem o objetivo não só de formar professores com competência técnica, mas, sobretudo com o comprometimento político, ou seja, espera-se que o professor possa interferir na dinâmica social, interpretando-a e dando-lhe novos rumos.

Para tanto, pretendem oferecer aos alunos uma "uma sólida formação teórica e prática que favoreça a reflexão contextualizada sobre os principais problemas da Educação Física e aponte possibilidades para a atuação de cada profissional em seu campo de trabalho (Ibdem, 2004, p. 12). Embora o projeto procure romper em sua estrutura e funcionamento curricular com a dicotomia teoria e prática, nesse enunciado, assume-se essa divisão, colocando em campos opostos a formação teórica e a formação prática.

Mais a frente, postula um novo currículo com uma formação sólida, de caráter generalista que permita o aprofundamento sobre conhecimentos no campo da educação para além do magistério, tornando-o capaz de fazer a mediação entre as teorias educacionais e as 
questões ligadas à formulação de políticas públicas na área, à direção e a coordenação do trabalho nas escolas e à atuação em espaços não-formais onde ocorram processos educativos, dispondo também das habilidades de investigador (UNEB- Campus XII, 2004). Nesse ponto, os autores postulam uma formação generalista, apoiada na Resolução CFE $n^{\circ}$ 03/87, indicando a necessidade do domínio de conhecimentos que habilite o profissional a atuar nos diversos campos de intervenção do professor de Educação Física. Seria oportuno refletirmos se existe a possibilidade de conciliarmos uma formação sólida para intervir em tantos espaços de intervenção com características diferenciadas. Reafirmando a hipótese anterior, o currículo continua, nessa perspectiva ampliada de formação, sendo subsumido ao atendimento do vasto campo de atuação da Educação Física. Há uma disputa em torno de espaço no currículo para abrigar as especificidades da atuação do campo escolar e não escolar. Em outros cursos, como o exemplo de pedagogia nesse mesmo Campus XII, a formação é generalista, mas, há uma delimitação da ação pedagógica seja na Educação Infantil, Anos Iniciais do Ensino Fundamental, Supervisão, etc. Portanto, torna-se impossível promover uma formação sólida, em virtude da necessidade de domínio técnico-instrumental para atuar em diversos campos de trabalho. Comprovaremos essa hipótese quando analisarmos os componentes curriculares da matriz curricular.

Notamos, na sequência, que os autores abordam a questão da organização curricular que não foi anunciado no subtítulo ora estudado. Entretanto, o fazem, para reafirmarem a perspectiva do currículo integrado da proposta. Assim, passam a explicar inicialmente a fundamentação legal da proposta curricular.

A organização curricular aqui proposta fundamenta-se na Resolução CNE/CP $n^{\circ} 1 / 2002$ :

Art. 14 - "Nestas Diretrizes, é enfatizada a flexibilidade necessária, de modo que cada instituição formadora construa projetos inovadores e próprios, integrando os eixos articuladores nelas mencionados".

$\S 1^{\circ}$ A flexibilidade abrangerá as dimensões teóricas e práticas, de interdisciplinaridade, dos conhecimentos a serem ensinados, dos que fundamentam a ação pedagógica, da formação comum e específica, bem como dos diferentes âmbitos do conhecimento e da autonomia intelectual e profissional.

$\S 2^{\circ} \mathrm{Na}$ definição da estrutura institucional e curricular do curso, caberá a concepção de um sistema de oferta de formação continuada, que propicie oportunidade de retorno planejado e sistemático dos professores às agências formadoras. (UNEB - Campus XII, 2004, p.12)

Em seguida, reafirmam a necessidade de pensar um currículo flexível e integrado que supere o modelo de currículo em disciplinas isoladas, para que o professor trabalhe numa 
perspectiva diferente da qual ele próprio foi formado, observando o conhecimento como compartimentos estanques. É fundamental que o aluno perceba as inter-relações básicas entre disciplinas. Nesse sentido, a divisão disciplinar que caracteriza a fragmentação do conhecimento será superada pela articulação sistemática das áreas do conhecimento através dos diversos componentes (Ibdem, 2004).

Para nós, representa um grande avanço, do ponto de vista curricular e da formação profissional a organização desse currículo prescrito, na medida em que busca romper com a fragmentação e compartimentalização das disciplinas da antiga estrutura. Outra questão é que, ao contrário das análises de que a "flexibilidade curricular" seria uma orientação das atuais Diretrizes que promoveria o empobrecimento da formação, percebemos que, na prática, esse conceito vem se constituindo como uma possibilidade de reconfiguração curricular, capaz de romper com os limites da formação anterior. A prática da interdisciplinaridade parece ser algo marcante nessa proposta curricular, sendo a forma encontrada para fazer avançar a formação profissional tornando-a mais concreta e contextualizada.

Para colocar em prática os objetivos propostos pelo curso de Educação Física na UNEB - Campus XII, estabeleceu diretrizes a fim de assegurar a qualidade da formação. São elas:

- A quebra total da visão fragmentada de homem, tal qual existe hoje dentro dos cursos de Educação Física. É necessário uma visão holística que compreenda o homem como um ser indivisível;

- A superação de práticas pedagógicas, usualmente adotadas nos termos exclusivos de base positivista, substituindo-as por práticas produtivo-criativas, vinculadas à atividade social que estimulam a aprendizagem significativa;

- A implementação de um modelo metodológico que contemple o estabelecimento de uma rotina didática, baseada na experimentação, por meio de atividades docentes, buscando eliminar a dicotomia teoria-prática;

- O estabelecimento de uma relação professor-aluno dialógica e comunicativa, de forma que permita um processo de decisão, execução e avaliação participativa e cooperativa, numa perspectiva de construção coletiva, como deve ser a produção de conhecimento na Universidade;

- A ruptura de uma visão idealista e abstrata de Educação/Educação Física, tendo como referência principal o processo de trabalho de intervenção sócio-pedagógica, como núcleo essencial da formação profissional; 
- A concepção do currículo, não como uma simples agregação de disciplinas, mas como um conjunto articulado de atividades que possibilitam a transmissão do conhecimento por meio de variados procedimentos pedagógicos e acadêmicos, adequados a seus conteúdos.

As Diretrizes anunciadas repetem basicamente aquilo que foi destacado em relação aos princípios do curso. O foco desses pontos está no rompimento da dicotomia entre a teoria e a prática, trazendo como novidade a concepção de currículo como prática a partir de variados procedimentos pedagógicos e acadêmicos adequados a seus conteúdos (UNEB - Campus XII, 2004).

Encerrando a análise dessa categoria, identificamos que, embora o seu propósito fosse apresentar a concepção, finalidades e objetivos do curso, o texto dá um destaque maior para as finalidades e os objetivos. Com isso, acreditamos que a proposta necessita de uma discussão mais consistente a respeito da concepção do curso e de profissional que deseja formar.

\title{
3.2.3 - Perfil profissiográfico
}

Com relação ao perfil do profissional que se pretende formar temos os seguintes requisitos:

\begin{abstract}
Exercer, de forma contextualizada, uma função educadora de maneira ampliada, tanto na área escolar (da educação básica e/ou superior), quanto em outras, a exemplo de clubes, academias, condomínios, associações desportivas, centros sociais urbanos, clínicas e treinamento personalizado entre outros; Possuir um nível de criticidade sobre o conteúdo produzido ao longo da sua formação, voltado para o exercício pleno de sua cidadania e dos seus alunos; Aplicar e contextualizar o conteúdo da Educação Física, na perspectiva de estimular a consciência crítica nos seus alunos, no momento em que estiver atuando nos vários campos; Identificar, compreender e analisar criticamente as necessidades regionais e universais podendo refletir e decidir, de forma autônoma, sobre o que é significativo como referência cultural, para que através de uma prática multidisciplinar produza novos conhecimentos; Considerar o ambiente de trabalho um espaço coletivo, utilizando-o como um meio para suas ações, sem perder de vista a perspectiva da preservação e manutenção do mesmo (UNEB-Campus XII, 2004, p. 17 ).
\end{abstract}

A opção pela formação generalista pode ser percebida no primeiro atributo do profissional que é o domínio de conhecimentos que o permita atuar na área escolar (Educação Básica e Superior), quanto em outras áreas como clubes, academias, condomínios, associações 
desportivas, centros comunitários, clínicas e treinamento personalizado entre outros. Em nossa análise, a opção pela formação generalista nos moldes como vem se configurando a partir da Resolução CFE $n^{\circ}$ 03/87, tem priorizado sobremaneira as demandas do mercado de trabalho. $\mathrm{Na}$ análise da estrutura curricular do curso, comprovamos que a seleção de conhecimentos se dá, via de regra, em função das necessidades de atuação profissional nesse mercado de trabalho efêmero da Educação Física.

Embora ressalte o desenvolvimento do nível de criticidade dos alunos sobre o conteúdo produzido ao longo da formação, o direciona de forma superficial e não para a formação do sujeito crítico, agente da transformação social.

Nos quesitos seguintes os termos criticidade, contextualização, autonomia, são empregados de maneira mais adequada e voltada realmente para a formação do sujeito numa perspectiva crítica. O último quesito parece confuso e sem vinculação com os interesses da formação profissional sendo, portanto, dispensável a esse tópico do projeto.

\subsection{4 - Habilidades e competências}

Por meio desse tópico/categoria, os autores alinham o projeto às exigências da Lei $\mathrm{n}^{\mathrm{o}}$ 9394/96 (LDB) e, em consequência desta lei maior, à Resolução CNE/CP nº 01/02, ao fazer opção pelo modelo de habilidades e competências na formação.

\footnotetext{
Atuar profissionalmente, compreendendo a natureza humana em suas dimensões, em suas expressões e fases evolutivas; Dominar os métodos e técnicas para o ensino da Educação Física, nos diversos espaços de atuação profissional; Utilizar a pesquisa e extensão como meios de analisar e interpretar a Educação Física na sociedade; Ampliar o conhecimento do aluno, através da diversificação e abordagem dos conteúdos da cultura corporal; Exercer o papel de educador de forma autônoma, crítica e contextualizada; Identificar as necessidades regionais e universais em relação à Educação Física; Atuar de forma crítica e criativa frente à realidade social; Reconhecer o seu papel social, enquanto educador e agente de transformação social (UNEB-Campus XII, 2004, p. 18).
}

Analisando as habilidades e competências priorizadas pela proposta curricular, identificamos pelo menos três aspectos que merecem ser discutidos. O primeiro é que se confundem bastante com os objetivos da formação profissional, especialmente aqueles relacionados no tópico perfil profissiográfico. Dessa maneira, caberia questionar se não estaríamos falando de coisas análogas. Se a assertiva for verdadeira, então não precisaríamos 
dispor de dois tópicos para falar das mesmas coisas. A segunda é que, embora se pareçam, nesta redação, o conceito de criticidade aparece de forma mais adequada à formação do sujeito crítico, como por exemplo “ exercer o papel de educador de forma autônoma, crítica e contextualizada (...); Atuar de forma crítica e criativa frente à realidade social; Reconhecer o seu papel social, enquanto educador e agente de transformação social"(UNEB-Campus XII, 2004, p.18). O terceiro e último aspecto, é que os autores da proposta deixaram exatamente para o tópico mais polêmico e criticado pelos pesquisadores da área educacional e da Educação Física para apresentarem competências e habilidades que proporcionem uma formação verdadeiramente humana e crítica, contrariando, portanto, as teses que condenam as atuais diretrizes curriculares por estabelecerem relação direta com o modelo das competências e, consequentemente, com a lógica técnico-instrumental na formação. Sabemos que existem determinações sobre o processo de formação, mas, também, devemos reconhecer que existem margens para a proposição ou contestação dessas determinações. Nesse caso, as habilidades e competências preconizadas nesse projeto, se mostram radicalmente contrárias à lógica de mercado. Porém, não significa que na prática curricular isso se confirme como veremos mais à frente.

\subsection{5 - Estrutura curricular e abordagem metodológica}

Segundo os autores da proposta, a estrutura curricular foi elaborada a partir dos seguintes princípios:

Flexibilização na organização curricular, possibilitando opções aos alunos, permitindo-os cumprir percursos acadêmicos diferenciados, em atendimento aos anseios de realizações pessoais e as demandas do campo do trabalho e da sociedade.

Diversificação da formação garantindo aos alunos tanto a formação básica, geral, como uma formação diversificada atendendo às diferentes realidades e especificidades dos Departamentos da UNEB.

Autonomia dos Departamentos como a possibilidade concreta de atuarem apresentando soluções próprias para os problemas do curso, a partir das suas vivências, experimentações de novos currículos, de alternativas didáticas e pedagógicas já implementadas ou inovadoras, inéditas.

Interdisciplinaridade fator inerente ao desenvolvimento da proposta. Tem na Pesquisa e Prática e Prática Pedagógica o espaço tempo integrador e articulador das disciplinas e demais componente curriculares, visando à superação da rigidez e fragmentação disciplinar.

Contextualização permite a necessária articulação entre os mais variados componentes curriculares relacionando-os com o cotidiano dos alunos, com a realidade das escolas, com as características locais e regionais, enfim, em todos os espaços onde os processos educativos ocorrem. (UNEB-Campus XII, 2004, p.15) 
Ao destacarem esses princípios como elementos basilares da estrutura curricular, ressaltam a ideia de um "currículo integrado" ${ }^{33}$. Nessa perspectiva, espera-se por meio da integração dos componentes curriculares a partir de eixos temáticos geradores de discussão e reflexão, uma compreensão crítica e contextualizada da Educação Física.

A estratégia para alcançar esses objetivos, a julgar pelo destaque recebido, seria a “interdisciplinaridade". Por meio dela seria possível, segundo os autores, "acreditar na possibilidade de integração das diferentes áreas do saber, agregando-as às diversidades culturais, significa defender um novo tipo de pessoa mais aberta, mais flexível, solidária, democrática e crítica" (UNEB-Campus XII, 2004, p. 15).

Outro ponto bastante destacado é a flexibilização curricular. Segundo os autores do projeto de redimensionamento do Curso de Educação Física, “... hoje os vários segmentos que discutem o ensino superior compreendem que a flexibilização curricular e pedagógica é a possibilidade real de contrapormos a tradição normativa e autoritária do estado presente no ensino superior" (UNEB-Campus XII, 2004, p. 16). Para reafirmarem flexibilidade curricular, os autores se embasaram no princípio da autonomia universitária conferida pela Constituição de 1998 em seu Art.207, sinalizando esforços na construção de uma sociedade democrática. A Nova Lei de Diretrizes e Bases da Educação Nacional (9.394 de 20 de /12/1996) reitera este princípio e dá outros desdobramentos que influenciaram na vida das IES (Ibdem, 2004, p. 15).

Ao contrário das críticas proferidas por vários pesquisadores ao princípio da "flexibilidade curricular", sobretudo aqueles que vinculam as diretrizes curriculares ao projeto neoliberal, os autores dessa proposta consideram-na um elemento importante para melhorar a qualidade da formação, tornando-a mais crítica, reflexiva, integrada e contextualizada. Arrematam dizendo que

A flexibilização curricular permite uma formação em nível superior respaldada no conceito contemporâneo de sociedade, onde o conhecimento é tratado como a base de construção da diversidade cultural e tecnológica, estabelecendo uma relação diferente com o conhecimento incorporado pelo

\footnotetext{
${ }^{33}$ Sob o argumento da teoria crítica, a organização integrada do currículo, mais que uma estratégia didática, traduz uma filosofia sociopolítica, tem implícita uma concepção de socialização das novas gerações, um ideal de sociedade, do sentido e do valor do conhecimento e como se pode facilitar os processos de ensino e aprendizagem (Giroux, 1997, 2003; Torres Santomé, 1998, 2004; Lopes e Macedo, 2002; Beane, 2003). A integração de campos do conhecimento e experiência teria em vista facilitar uma compreensão mais reflexiva e crítica da realidade, ressaltando não só dimensões centradas nos conteúdos culturais, mas também o domínio dos processos necessários ao alcance de conhecimentos concretos, a compreensão de como o conhecimento é produzido e as dimensões éticas inerentes a essa tarefa (Torres Santomé, 1998).
} 
futuro profissional considerando a historicidade de sua produção, a epistemologia de cada área e os impactos destes conhecimentos sobre a sociedade e a cultura, ou seja um currículo que garanta não apenas a assimilação das aplicações técnicas mas também o domínio de fundamentos, não como um fim em si, mas como uma construção e interpretação própria do agir e interagir numa realidade concreta (UNEB-Campus XII, 2004, p.16).

Assim, podemos inferir que a proposta sinaliza para a formação de sujeitos capazes de compreender criticamente a realidade. Em que pese os limites dessa apropriação por parte dos alunos e futuros professores, em virtude dos problemas na formação e qualificação dos docentes da Educação Superior, parece a proposta dispor de uma estrutura que possibilita isso. É interessante perceber que, embora as análises sobre as diretrizes curriculares atuais enquadremna como uma normativa conservadora e fundada no paradigma da racionalidade técnica, o produto curricular construído pelo coletivo do Campus XII parece destoar dessa lógica. Nesse sentido, é preciso ampliar os estudos sobre as propostas curriculares a fim de identificarmos esse dado com maior propriedade. Para uma melhor compreensão do leitor, apresentaremos no quadro abaixo a estrutura curricular do curso.

\section{Quadro XIV: Estrutura Curricular do Curso de Educação Física da UNEB - Campus XII}

\section{TÓPICOS DE ESTUDOS PARA A FORMAÇÃO BÁSICA}

\begin{tabular}{|c|c|}
\hline 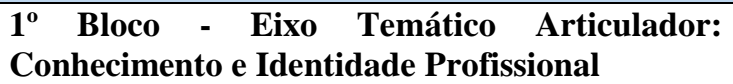 & $\begin{array}{l}2^{\circ} \text { Bloco - Eixo Temático Arti } \\
\text { Epistemológicas da Educacão Fí }\end{array}$ \\
\hline $\begin{array}{l}\text { Aspectos Filosóficos da Educação Física (60h) } \\
\text { A Biologia e a Prática da Educação Física }(60 \mathrm{~h}) \\
\text { Aspectos Históricos da Educação Física (45h) } \\
\text { Os Campos de Atuação do Profissional da Educ. } \\
\text { Física (Trabalho Orientado) (60) } \\
\text { Laboratório de Vivências e Práticas Corporais } \\
\text { (Ginástica) (60) } \\
\text { Laboratório de Leitura e Interpretação de Texto (60) } \\
\text { Pesquisa e Prática Pedagógica I (45) }\end{array}$ & $\begin{array}{l}\text { A Fisiologia Humana e a Prática da Educação Física } \\
\text { ( } 75 \text { h) } \\
\text { Anatomia Humana e a Prática da Educação Física } \\
\text { (60h) } \\
\text { Aspectos Sociológicos e Antropológicos da } \\
\text { Educação Física ( } 75 \text { h) } \\
\text { Fundamentos Psicológicos da Educação Física } \\
\text { (75h) } \\
\text { Aspectos Históricos da Educação Física (45) } \\
\text { Laboratório de Vivências e Reflexões de Práticas } \\
\text { Corporais (Natação) (60h) } \\
\text { Laboratório de Leitura e Produção de Texto (60h) } \\
\text { Pesquisa e Prática Pedagógica II (60h) }\end{array}$ \\
\hline $\begin{array}{l}3^{\circ} \text { Bloco }- \text { Eixo } \quad \text { Temático Articulador: } \\
\text { Conhecimento e Prática Pedagógica }\end{array}$ & $\begin{array}{l}\text { Bloco }- \text { Eixo } \\
\text { Conhecimento e Prátic }\end{array}$ \\
\hline $\begin{array}{l}\text { Educação Física, Currículo e as Políticas } \\
\text { Educacionais (60h). } \\
\text { Fisiologia e a Prática da Educação Física (60h) } \\
\text { Cinesiologia e a Prática da Educação Física }(60 \mathrm{~h}) \\
\text { Fundamentos Teóricos e Metodológicos da } \\
\text { Capoeira (60h) }\end{array}$ & $\begin{array}{l}\text { As Dimensões da Avaliação no Processo Educativo } \\
\text { (60h) } \\
\text { As Práticas da Educação Física no Lazer }(60 \mathrm{~h}) \\
\text { Fundamentos Teóricos e Metodológicos da } \\
\text { Avaliação Funcional }(60 \mathrm{~h})\end{array}$ \\
\hline
\end{tabular}




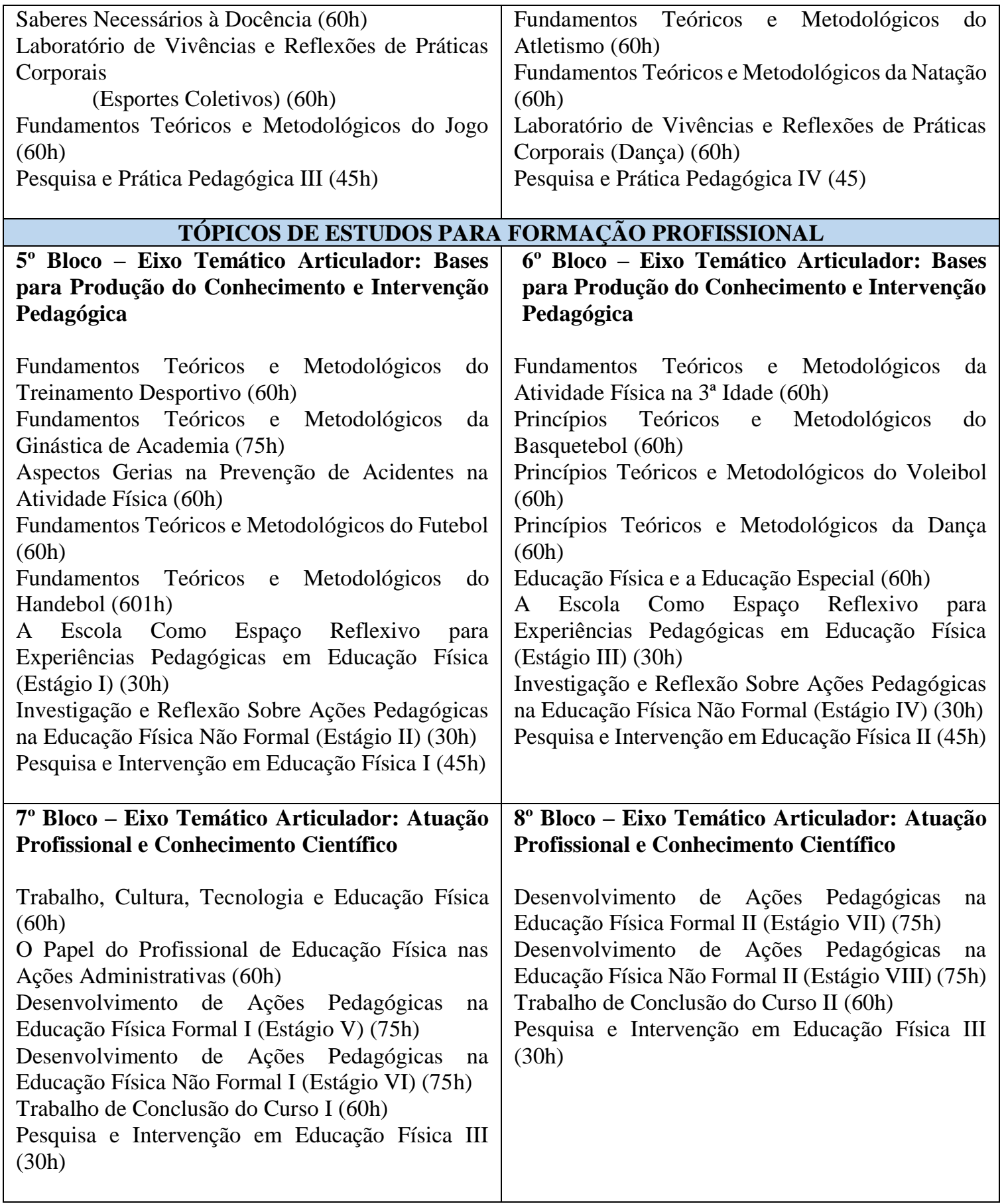

Fonte: (UNEB-Campus XII, 2004)

Quanto à organização formal, a matriz foi construída a partir de Tópicos de Estudos para a Formação definidos em função do que se considerou como básico e optativo na formação do profissional de educação física. Estes serão elementos instrumentadores na medida em que terão um objeto de formação. Serão compostos de EIXOS TEMÁTICOS que se integrarão e ao mesmo tempo serão também articuladores dos diversos componentes curriculares: disciplinas, seminários temáticos, pesquisa e prática pedagógica estágio e pesquisa, dentre outras (UNEB-Campus XII, 2004). 
Neste currículo, teremos dois Tópicos de Estudos para a Formação: Tópicos de Estudos para a Formação Básica e Tópicos de Estudos para a Formação Profissional. Conforme se especifica no projeto, será obrigatória a matrícula no Núcleo de Formação Básica para todos os alunos que ingressam no curso de Educação Física. "O referido núcleo constitui-se na essência do saber característico que estabelece a formação do profissional de educação física, sua área de atuação profissional, etc. Nele será garantido o acesso às bases gerais e amplas de formação" (UNEB-Campus XII, 2004, p.19).

Um dos aspectos inovadores da organização curricular é a noção de eixos temáticos articuladores. Para cada bloco (semestre), existe uma temática que fará a integração dos componentes curriculares por meio de um componente específico chamado nos quatro primeiros blocos integrantes da formação básica de Pesquisa e Prática Pedagógica (I, II, III e IV). No primeiro bloco, temos a temática Conhecimento e Identidade Profissional; no segundo Bases Epistemológicas da Educação Física; no terceiro e no quarto, Conhecimento e Prática Pedagógica. A integração ou interdisciplinaridade é feita por meio de atividades como: seminários temáticos, estudos dirigidos, sessões científicas, etc (UNEB-Campus XII, 2004).

No tocante aos componentes selecionados que representam em essência os conhecimentos a serem adquiridos pelos alunos a fim de dominarem as bases mais amplas de uma formação voltada para a docência, percebemos que existem sérias contradições. A primeira contradição encontra-se entre o que se anuncia em relação ao Tópico de Estudos para a Formação Básica e os componentes que integram os blocos que acabam não priorizando esses objetivos ou, no máximo, contemplando parcialmente. Como exemplo, temos diversos componentes ligados à parte biológica (Biologia, Fisiologia Humana, Anatomia Humana, Cinesiologia) que não guardam relação com a formação básica para a docência numa licenciatura. Entretanto, existem componentes que dão margem a apreensão desses objetivos como: Saberes Necessários à Docência, Dimensões da Avaliação no Processo Educativo, Aspectos Históricos da Educação Física, Fundamentos Psicológicos da Educação Física, Educação Física, Currículo e as Políticas Educacionais, Aspectos Filosóficos da Educação Física).

A segunda contradição é que, embora essa primeira etapa do curso compreendida em quatro semestres priorize a formação básica, existe na matriz curricular componentes que tratam da formação profissionalizante como: Os Campos de Atuação Profissional da Educação Física, Fundamentos Teóricos e Metodológicos da Capoeira, Fundamentos Teóricos e Metodológicos do Jogo, As Práticas da Educação Física no Lazer, Fundamentos Teóricos e Metodológicos da Avaliação Funcional, Fundamentos Teóricos e Metodológicos do Atletismo, Fundamentos 
Teóricos e Metodológicos da Natação. Aqui, sobretudo, em relação ao primeiro componente listado, os campos de atuação profissional, percebemos a ideia da "simetria invertida" já discutida nesse trabalho e presente nessa matriz curricular.

A terceira e última contradição que destacamos nesse primeiro núcleo de formação, a formação básica, é que nos parece, pelos componentes e conhecimentos selecionados para a abordagem pedagógica e, também, a perspectiva generalista de formação assumida nesse projeto, que há uma preocupação em atender duas perspectivas de formação. Uma voltada para a formação do docente e, portanto, com uma gama de conhecimentos da área pedagógica e, outra, voltada para a formação do Técnico (Bacharel) agregando os conhecimentos das áreas biomédicas e técnico-esportiva.

Com relação aos Tópicos de Estudos para a Formação Profissional, repete-se a mesma organização no que tange ao processo de articulação entre os componentes curriculares que, nesse caso, ocorrerá por meio da atuação do componente Pesquisa e Intervenção em Educação Física (PIEF). Para cada bloco, do $5^{\circ}$ ao $8^{\circ}$, PIEFs de I a IV respectivamente. Os eixos temáticos são os seguintes: Bases para a Produção do Conhecimento e Intervenção Pedagógica no quinto e sexto blocos e Atuação Profissional e Conhecimento Científico no sétimo e oitavo blocos. A partir dessa organicidade, assim se caracteriza o núcleo de formação profissional no projeto.

Estando o curso de Educação Física voltado para uma concepção generalista, existe a possibilidade de se atender às demandas variadas de formação de profissionais para atuar em espaços educativos existentes, ou que venham a constituir-se na sociedade. Para que isto aconteça, estamos apontando para um trabalho de observação e investigação no quinto e sexto semestres, como forma de preparação para elaboração e aplicação de uma proposta de intervenção pedagógica no sétimo e oitavo semestre. Os tópicos de estudos de formação profissional serão, também, transversalizados pelas práticas pedagógicas de formação e intervenção vivenciadas ao longo dos semestres, como: seminários temáticos, estudos dirigidos, sessões científicas (UNEBCampus XII, 2004, p. 21)

Mais uma vez aparece no projeto a concepção de formação generalista subsumida às demandas de trabalho da sociedade. Para tanto, opera-se a lógica, já destacada nesse trabalho, da fragmentação da prática de ensino em duas modalidades de estágio. No quinto bloco, temos como exemplo dessa divisão os seguintes componentes ligados ao estágio: A Escola como Espaço Reflexivo para Experiências Pedagógicas em Educação Física (Estágio I - 30h) e Investigação e Reflexão sobre Ações Pedagógicas na Educação Física não Formal (Estágio II 30h). No sexto bloco, temos: A Escola como Espaço Reflexivo para Experiências Pedagógicas 
em Educação Física (Estágio III - 30h) e Investigação e Reflexão sobre Ações Pedagógicas na Educação Física não Formal (Estágio IV - 30h).

Portanto, nesses dois blocos os estágios têm a finalidade de caracterizar e observar os campos de atuação profissional que, nesse caso, encontram-se dicotomizados em formal (escolar) e não formal (não escolar).

No sétimo e oitavo blocos, respectivamente, a divisão permanece com os seguintes componentes de estágio: Desenvolvimento de Ações Pedagógicas na Educação Física Formal I (Estágio V - 75h) e Desenvolvimento de Ações Pedagógicas na Educação Física Não Formal I (Estágio VI - 75h); Desenvolvimento de Ações Pedagógicas na Educação Física Formal II (Estágio VII - 75h) e Desenvolvimento de Ações Pedagógicas na Educação Física Não Formal II (Estágio VIII - 75h).

Se a Resolução CNE/CES no 07/2004 recebe o crédito pela divisão da formação em Educação Física, poderíamos, tranquilamente, avaliar que esse modelo fragmentado em relação à prática de ensino (estágio supervisionado), mesmo sendo estabelecido num curso de licenciatura, teria o mesmo poder da referida resolução. Primeiro, um estágio de 400 horas num curso de Licenciatura em Educação Física que, em tese, deveria ser dedicado ao conhecimento, caracterização, observação e intervenção na Educação Básica é dividido ao meio, a fim de atender ao mercado de trabalho emergente da Educação Física. Com isso, é reduzido ao aluno o conhecimento da realidade escolar brasileira e da Educação Física nos diversos níveis e modalidades escolares. Podemos ir mais longe, ao identificar que o currículo em função disso, é construído, do ponto de vista da seleção de conhecimentos, da priorização de componentes e experiências no campo do ensino, pesquisa e extensão para atender às múltiplas demandas do mercado de trabalho. Portanto, nesse aspecto, a atual configuração curricular do curso de Educação Física da UNEB-Campus XII não avança quando se avalia os reais objetivos de uma formação em nível de licenciatura.

Para além da análise da prática de ensino (estágio supervisionado) no processo de formação profissional, percebemos que a seleção de componentes curriculares segue a lógica do atendimento das demandas do mercado de trabalho contemplando o espaço formal e não formal com conhecimentos, especialmente do campo teórico-metodológico. Assim, temos componentes como Fundamentos Teóricos e Metodológicos do Treinamento Desportivo (60h), Fundamentos Teóricos e Metodológicos da Ginástica de Academia (75h), Aspectos Gerais na Prevenção de Acidentes na Atividade Física (60h), Fundamentos Teóricos e Metodológicos da Atividade Física na $3^{\mathrm{a}}$ Idade, O Papel do Profissional de Educação Física nas Ações Administrativas para atender a área não formal(não escolar) da Educação Física. Por outro lado, 
componentes como Fundamentos Teóricos e Metodológicos do Futebol (60h), Fundamentos Teóricos e Metodológicos do Handebol (60h), Princípios Teóricos e Metodológicos do Basquetebol (60h), Princípios Teóricos e Metodológicos do Voleibol (60h), Princípios Teóricos e Metodológicos da Dança (60h), Educação Física e a Educação Especial (60h), Trabalho, Cultura, Tecnologia e Educação Física (60h) voltados mais para a área formal (escolar). Uma análise importante e que representa uma contradição nessa matriz curricular é que, por um lado ela avança numa dinâmica interdisciplinar e de apropriação do conhecimento de forma integrada e reflexiva, e, por outro, apresenta claros sinais de fragmentação do conhecimento, da teoria e da prática, ao compartimentalizar os conteúdos da cultura corporal em componentes diferenciados. Se pensarmos que a Educação Física Escolar tem como foco o ensino das expressões corporais constituídas historicamente a partir de um processo reflexivo, contextualizado com a dinâmica social, política e econômica, então não necessitaríamos estudar essas expressões em separado, a não ser que o interesse fosse de domínio meramente técnicoinstrumental. Também não dispomos nessa matriz curricular de componentes que estudem, por exemplo, a constituição histórica dos conteúdos/categorias/elementos da cultura corporal como o esporte, a dança, as lutas, a ginástica, os jogos, etc. Em relação à ginástica por exemplo, na matriz, especifica-se como "ginástica de academia", um fenômeno coisificado em nossa sociedade dando mostras da subsunção do currículo ao mercado. Portanto, poderíamos perguntar onde e quando se estudaria, nessa matriz curricular, a ginástica enquanto elemento mais amplo da cultura corporal?

Para finalizarmos a análise da estrutura curricular e abordagem metodológica do curso, gostaríamos apenas de destacar o esquema de configuração da matriz curricular, disponível nos anexos desse trabalho. Para nós, um dos aspectos relevantes na proposta curricular por apresentar um formato original e inovador em relação às antigas configurações curriculares, denominadas de "grade curricular" 34 com suas amarrações, disciplinas estanques, pré-requisitos entre outros aspectos que contribuíam para um currículo fragmentado. Nessa nova perspectiva, os componentes se apresentam entrelaçados numa clara disposição interdisciplinar.

\subsection{6 - Formas de avaliação}

Com relação ao processo de avaliação, após análise dessa categoria na proposta curricular do curso, podemos distingui-la em duas vertentes: Avaliação didático-pedagógica ou

\footnotetext{
${ }^{34}$ Grade curricular
} 
avaliação do ensino-aprendizagem e avaliação da prática pedagógica do curso. Sobre a primeira vertente, a avaliação didático-pedagógica,

...fundamenta-se numa perspectiva emancipatória onde o aluno, a partir da
reflexão da sua prática pedagógica associando-a aos conceitos teóricos
discutidos ao longo do curso permita-lhe desenvolver uma proposta de
autonomia pessoal e desenvolvimento profissional que extrapole os modelos
tradicionais de avaliação. Nessa perspectiva, consideramos avaliação como o
ponto culminante do processo ensino-aprendizagem que se traduz na
construção de textos, na análise de situações vividas e na construção do
conhecimento. (UNEB-Campus XII, 2004, p. 66)

A avaliação pensada nessa vertente se refere aos processos avaliativos inerentes à prática pedagógica dos professores junto aos componentes curriculares. Aponta para um modelo de avaliação processual e contínuo que assegure o desenvolvimento da autonomia e do conhecimento profissional. Nega, portanto, os métodos tradicionais de avaliação, muito embora, não tenhamos dados suficientes para demonstrar se, na prática, isso ocorre realmente. O que temos como suposto é que a cultura avaliativa da área da saúde e a área sócio-pedagógica são diferenciadas, tendo as última uma maior proximidade com métodos dialéticos de avaliação, ao contrário da primeira que se alinha muito mais com os métodos tradicionais.

Sobre a segunda vertente, se configura numa espécie de avaliação interna sobre o desempenho do curso. Nesse caso, a avaliação ao longo do desenvolvimento do curso "tendo como pressupostos básicos a avaliação participativa e processual, atendendo aos diversos níveis de avaliação, tais como: atitude de responsabilidade da instituição, dos professores e dos alunos acerca do processo formativo"(UNEB-Campus XII, 2004, p. 66). Observa-se aqui que, para além da avaliação institucional externa proposta pelo MEC, denominada incialmente como "Provão" e depois como Exame Nacional de Desenvolvimento de Estudantes - ENADE visando aferir a qualidade dos cursos, estabelecendo notas de 0 a 5 , o curso se propõe a avaliar processualmente o ensino-aprendizagem envolvendo todos os segmentos acadêmicos partícipes da execução curricular. Infelizmente, a nossa pesquisa não se propôs a identificar se esse processo previsto no projeto do curso vem acontecendo regularmente, o que por certo, poderá se constituir em proposições de pesquisa futuras, elegendo como temática o processo de avaliação junto ao curso.

Para o momento e, considerando os limites desse trabalho, é importante reconhecer que o processo avaliativo do curso, tanto no que se refere à avaliação do ensino-aprendizagem junto às atividades curriculares, como à avaliação mais ampla do curso, assumem uma perspectiva avançada de avaliação. 


\subsection{7 - Análise do ementário do curso}

O curso de Educação Física da UNEB-Campus XII é composto por 55 componentes curriculares. Destes, 8 componentes possuem carga horária de 75 horas, 35 com 60 horas, 7 com 45 horas e 6 com 30 horas. Juntos, somam 3.195 horas no total.

Para alcançar os objetivos, habilidades e competências estabelecidas no projeto é necessário selecionar determinados conhecimentos/conteúdos e disponibilizá-los no interior do projeto sob a forma de ementas que nada mais são que os conteúdos básicos a serem abordados/ensinados ao longo do percurso formativo do aluno. A definição das ementas dos componentes curriculares de um curso talvez seja um das tarefas mais complexas no processo de construção de uma proposta curricular em função da natureza provisória do conhecimento. Nesse sentido, as ementas precisam ser periodicamente atualizadas e acrescidas a fim de ampliar e atualizar o conhecimento e a formação profissional dos alunos.

No caso específico desse projeto, percebemos variados limites em relação à coerência, adequação e abrangência dos conteúdos listados, talvez em virtude da natureza transitória do conhecimento ou das condições objetivas em relação à construção das ementas.

Pudemos observar em primeiro plano a sobreposição de conteúdos, ou seja, componentes que apresentam conteúdos já estudados em momentos anteriores do curso. Outro aspecto que merece destaque é a inadequação ou incoerência dos conteúdos relacionados nas ementas aos objetivos originais dos componentes, ou seja, não há possibilidade do domínio dos conhecimentos, competências e habilidades que seriam acrescidos à formação profissional a partir de um determinado componente curricular em virtude dos conhecimentos relacionados na ementa guardarem pouca relação com essas finalidades.

Em continuidade, percebemos algo bastante curioso que foi a presença de eixos temáticos diferentes para o mesmo bloco em pontos diferentes do projeto. Assim, quando identificamos os eixos temáticos no tópico "estrutura curricular", vimos os seguintes eixos temáticos do $1^{\circ}$ ao $4^{\circ}$ bloco: Conhecimento e Identidade Profissional, Bases Epistemológicas da Educação Física, Conhecimento e Prática Pedagógica, Conhecimento e Prática Pedagógica. Já no tópico "Definição das Ementas" temos os seguintes eixos temáticos do $1^{\circ}$ ao $4^{\circ}$ bloco: Educação e Sociedade, Bases Epistemológicas da Educação Física, Conhecimento e Intervenção Pedagógica, Conhecimento e Intervenção Pedagógica. Consideramos grosseiros esses erros porque não se tratam apenas de erros ortográficos ou de digitação, pois as temáticas são completamente diferentes. Para além de outras análises, poderíamos nos perguntar qual dos 
tópicos estariam corretos. No $3^{\circ}$ e $4^{\circ}$ blocos, por exemplo, a confusão é maior, porque num tópico, o currículo prevê a abordagem pedagógica sobre o conhecimento e prática pedagógica, enquanto num segundo tópico, o currículo deverá tratar do conhecimento e intervenção profissional. Nesse caso, achamos que o primeiro tópico parece mais coerente, pois, não há perspectiva de intervenção profissional nessa primeira metade do processo de formação.

Outra variável importante em relação à seleção de conteúdos/objetivos dos componentes por meio das ementas se refere aos componentes articuladores. Sua função original prevista pela abordagem metodológica da proposta curricular seria fazer a articulação dos componentes do bloco por meio da organização de trabalhos interdisciplinares. Todavia, ao analisarmos as ementas desse componentes, descobrimos que existem outras funções inerentes a eles como por exemplo a abordagem em relação à metodologia científica e da pesquisa, além de conhecimentos didáticos sobre a prática pedagógica da Educação Física. No quinto e sexto blocos, não conseguimos identificar nas ementas dos componentes Pesquisa e Intervenção em Educação Física I e II, responsável pela articulação dos outros componentes, qualquer menção à essa tarefa. Com isso, é possível inferir que há problemas em relação ao cumprimento do processo de integração e de interdisciplinaridade nesse período do curso.

Assim, tendo em vista as observações apresentadas em relação ao ementário do curso, entendo ser necessário uma criteriosa revisão do projeto a fim de corrigir determinadas imprecisões e incoerências em seu texto.

\subsection{8 - Análise do referencial bibliográfico}

Ao analisarmos o referencial bibliográfico do curso junto ao projeto, foi possível identificar 289 títulos, o que para nós revela-se bastante exíguo para um curso de formação profissional. Semelhante à orientação generalista do curso, existe uma divisão dos títulos em relação às áreas da saúde e sócio-pedagógica. Quando comparamos os títulos aos conteúdos priorizados pelos componentes, percebemos um certo distanciamento entre eles. Parece ter havido uma seleção de títulos de modo aleatório, não contemplando dessa forma, as necessidades de aprofundamento em relação ao conhecimento por parte de alunos e professores.

Finalizando a análise do projeto do curso, constatamos que muitas hipóteses lançadas puderam ser confirmadas. A principal é que o currículo se apresenta de forma eclética e difusa ao ajuntar conteúdos com objetivos e fins diferentes como se fosse uma só. Ao fazê-lo, empobrece a formação profissional e se aprisiona numa lógica de submissão ao mercado de trabalho da 
Educação Física. Entretanto, do ponto de vista da organização e dinâmica curricular, avança significativamente em relação às estruturas curriculares do passado. Na conclusão desse trabalho, avaliaremos a totalidade das hipóteses incialmente apresentadas no início desse capítulo.

\section{3 - A produção do conhecimento no Curso de Educação Física da UNEB - Campus XII: evidenciando a divisão da formação profissional}

A produção de conhecimento nos cursos de Licenciatura, em geral, está regulamentada pela Resolução CNE/CP n 01/2002 no Inciso IV do Art $2^{\circ}$ prevendo que a organização curricular de cada instituição observará o aprimoramento em práticas investigativas, no Inciso III do Art. $3^{\circ}$ que a formação de professores que atuarão nas diferentes etapas e modalidades da educação básica observará princípios norteadores desse preparo para o exercício profissional específico que considerem a pesquisa com foco no processo de ensino e de aprendizagem, uma vez que ensinar requer, tanto dispor de conhecimentos e mobilizá-los para a ação, como compreender o processo de construção do conhecimento e, finalmente, o Inciso V do Art. $6^{\circ}$ que na construção do projeto pedagógico dos cursos de formação dos docentes sejam consideradas as competências referentes ao conhecimento de processos de investigação que possibilitem o aperfeiçoamento da prática pedagógica.

Embora a maioria dos cursos tenham ajustado o seu projeto curricular no tocante à produção de conhecimento incluindo a prática da pesquisa enquanto estratégia de apreensão crítica do conhecimento e, também, formalizando esse processo por meio da instituição dos Trabalhos de Conclusão de Curso - TCC, no Departamento de Educação do Campus XII da UNEB, especificamente no Curso de Educação Física esse expediente foi previsto desde o início das suas atividades. Portanto, ao fazer o redimensionamento do curso a fim de adequá-lo às Resoluções CNE/CP 01 e 02/2002, essa orientação presente no documento já se encontrava contemplada no antigo currículo, tendo apenas que ajustá-lo ao período em que deveria ser iniciado e concluído no novo currículo.

Portanto, a experiência com a produção/reflexão sobre o conhecimento da área da Educação Física se dá, no âmbito do curso de Educação Física prioritariamente por meio dos TCCs, tendo sido produzido os primeiros trabalhos a partir do ano de 2003. Contudo, para fins dessa pesquisa, analisaremos a produção/reflexão de conhecimento a partir do novo currículo regulamentado pela Resolução $\mathrm{CNE} / \mathrm{CP}$ n$^{\circ} 01$ e 02/2002. Como a implantação do referido 
currículo se deu a partir de 2004, os primeiros trabalhos começaram a surgir a partir do ano de 2008, razão pela qual, utilizamos esse período para o início da nossa análise.

Esperamos com esse estudo compreender melhor as nuances desse processo. Diversos estudos demonstram que a formação nos cursos de licenciatura vem se apoiando em duas áreas de conhecimento: as ciências biomédicas e as ciências sociais e pedagógicas. Se analisarmos as atuais diretrizes de formação de professores perceberemos que as competências exigidas no processo de formação estão relacionadas com a docência na Educação Básica como podemos ver abaixo:

Art. $5^{\circ} \mathrm{O}$ projeto pedagógico de cada curso, considerado o artigo anterior, levará em conta que:

I - a formação deverá garantir a constituição das competências objetivadas na educação básica;

II - o desenvolvimento das competências exige que a formação contemple diferentes âmbitos do conhecimento profissional do professor;

III - a seleção dos conteúdos das áreas de ensino da educação básica deve orientar-se por ir além daquilo que os professores irão ensinar nas diferentes etapas da escolaridade;

IV - os conteúdos a serem ensinados na escolaridade básica devem ser tratados de modo articulado com suas didáticas específicas;

V - a avaliação deve ter como finalidade a orientação do trabalho dos formadores, a autonomia dos futuros professores em relação ao seu processo de aprendizagem e a qualificação dos profissionais com condições de iniciar a carreira.

Parágrafo único. A aprendizagem deverá ser orientada pelo princípio metodológico geral, que pode ser traduzido pela ação-reflexão-ação e que aponta a resolução de situações-problema como uma das estratégias didáticas privilegiadas. (Brasil, 2002)

Portanto, essa dualidade em relação às áreas do conhecimento pode provocar uma ruptura no processo de aquisição das competências pedagógicas, sobretudo aquelas relacionadas com o domínio do conhecimento sobre a Educação Básica.

As ciências biomédicas ou ciências da saúde presentes nos currículos dos cursos tem, invariavelmente, impulsionado a prática pedagógica dos futuros professores de Educação Física para o campo da saúde. Assim, as competências em grande número de cursos de "Licenciatura Ampliada", que são aqueles voltados para uma formação que assegure um amplo domínio de instrumentais ligados ao mercado de trabalho, tem convergido para o conhecimento muito mais do campo da saúde do que da Educação Básica.

Dessa forma se estabelece uma correlação de forças no processo formativo desempenhada por professores ligados às duas grandes áreas do conhecimento em Educação Física. Esse movimento perpassa o ensino, a pesquisa e a extensão. É comum surgir a partir 
dessa divisão interna estruturas como grupos de pesquisa, projetos de pesquisa e extensão, eventos que representam ou dão destaque às referidas áreas de conhecimento. Assim, entendemos que esse movimento dos atores sociais em torno da batalha das ideias em relação ao processo formativo é que motivam os caminhos da produção de conhecimento no curso de Educação Física e, consequentemente, definirá os rumos da prática pedagógica do futuro professor.

A identificação de nexos e contradições relacionadas com a produção dos TCCs poderá constituir-se em ponto de partida para a ressignificação desse processo. O suposto principal é de que a produção científica nesse nível possui uma configuração dualista em que parte dos trabalhos estão embasados na área da saúde e outra parte nas ciências sociais e pedagógicas. Tendo em vista que o projeto curricular se configura como uma licenciatura de caráter ampliado é compreensível a existência dessa ambiguidade. Entretanto, é importante que nos projetos em que a área da saúde esteja contemplada, os trabalhos possuam uma abordagem direcionada para o ambiente escolar.

Outros supostos é que existe uma relação entre a área de atuação do professor e a temática e base teórico-metodológica do trabalho; que a produção de conhecimento no curso reflete a sua estrutura curricular generalista (híbrido); que há uma superioridade das Ciências Biomédicas como base teórico-epistemológica para o desenvolvimento dos TCC no período de 2008 a 2013. Há também uma prevalência de trabalhos relacionados com a Atividade Física e Saúde em detrimento de trabalho voltados para o trato da Educação Física na Escola, objeto principal de intervenção pedagógica num curso de Licenciatura.

Assim posto, passaremos a analisar os dados da produção no período supracitado. Para tanto, foram coletados na Biblioteca do Departamento de Educação do Campus XII a capa e o resumo de todos os trabalhos produzidos pelos alunos do Curso de Educação Física no período de 2008 a 2013. A organização do trabalho se deu em formato monográfico, exceto o do ano de 2012 que foi apresentado em forma de artigo científico.

O material foi separado de acordo com o ano de produção/defesa e estabelecidas as seguintes categorias de análise: número total de trabalhos produzidos; distribuição por categorias temáticas; método de pesquisa e análise dos trabalhos; áreas de conhecimento a que estão relacionados os trabalhos; nível de formação dos orientadores; relação orientador/área de atuação no curso; relação formação/área de conhecimento dos trabalhos.

Visando apresentar os dados analisados de uma forma mais clara e objetiva, optamos pela confecção de gráficos explicativos que revelam determinadas tendências no fazer pedagógico e na produção científica no interior do curso. A ideia de que o currículo vivido é 
mais importante no processo formativo do que o currículo prescrito pode ser percebida a partir dos gráficos. Isso não nos furtou em analisar os números de forma crítica e contextualizada com a realidade da formação profissional desenvolvida nas Universidades Públicas Estaduais Baianas.

Assim, no primeiro gráfico temos um panorama quantitativo da produção científica no âmbito dos TCCs. No período de 2008 a 2013 tivemos a produção de 163 trabalhos. Procuramos também demonstrar a evolução da produção de conhecimento no curso verificando-se uma regularidade e estabilidade da produção com ressalva para o ano de 2011 quando houve a defesa 58 trabalhos representando mais que o dobro dos trabalhos do ano anterior e subsequente a ele. A explicação para isso foi que, em virtude das dificuldades com a manutenção e contratação de professores e, também, as limitações em relação à infraestrutura física provocaram a reação dos alunos que ocuparam o Campus por cerca de três meses. Como não houve condição de assegurar os prazos para a defesa dos trabalhos na época devida, muitos trabalhos acabaram sendo remanejados para esse período, justificando então esse elevado número.

\section{Gráfico I : Evolução da produção de conhecimento no Curso de Educação Física via TCC}

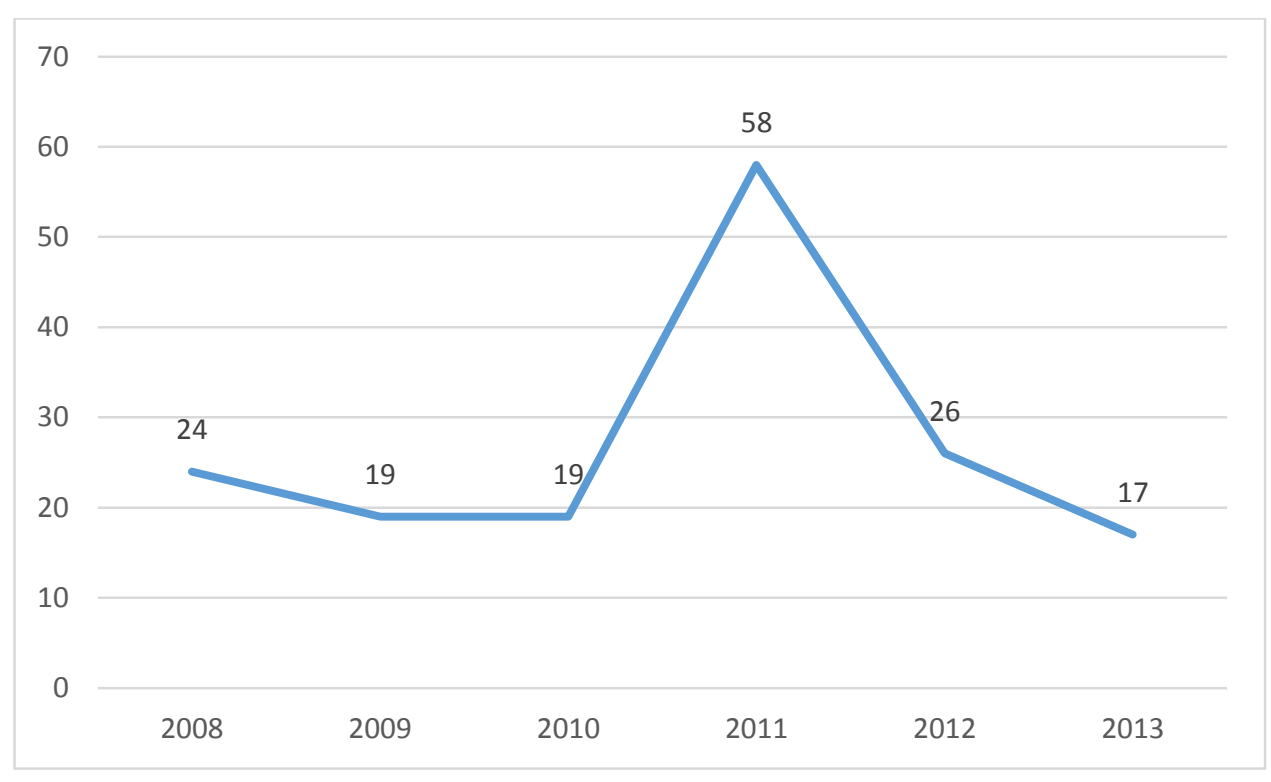

Fonte: próprio autor

Na sequência procuramos analisar como tem sido dado a distribuição desses trabalhos em termos temáticos, uma vez que o curso se configura como uma licenciatura ampliada buscando dar conta dos diversos campos de atuação profissional. Assim, no gráfico abaixo, 
apresentamos não só a distribuição dos trabalhos em termos temáticos como a evolução no período estudado.

\section{Gráfico II : Evolução dos trabalhos de tcc por categorias temáticas}

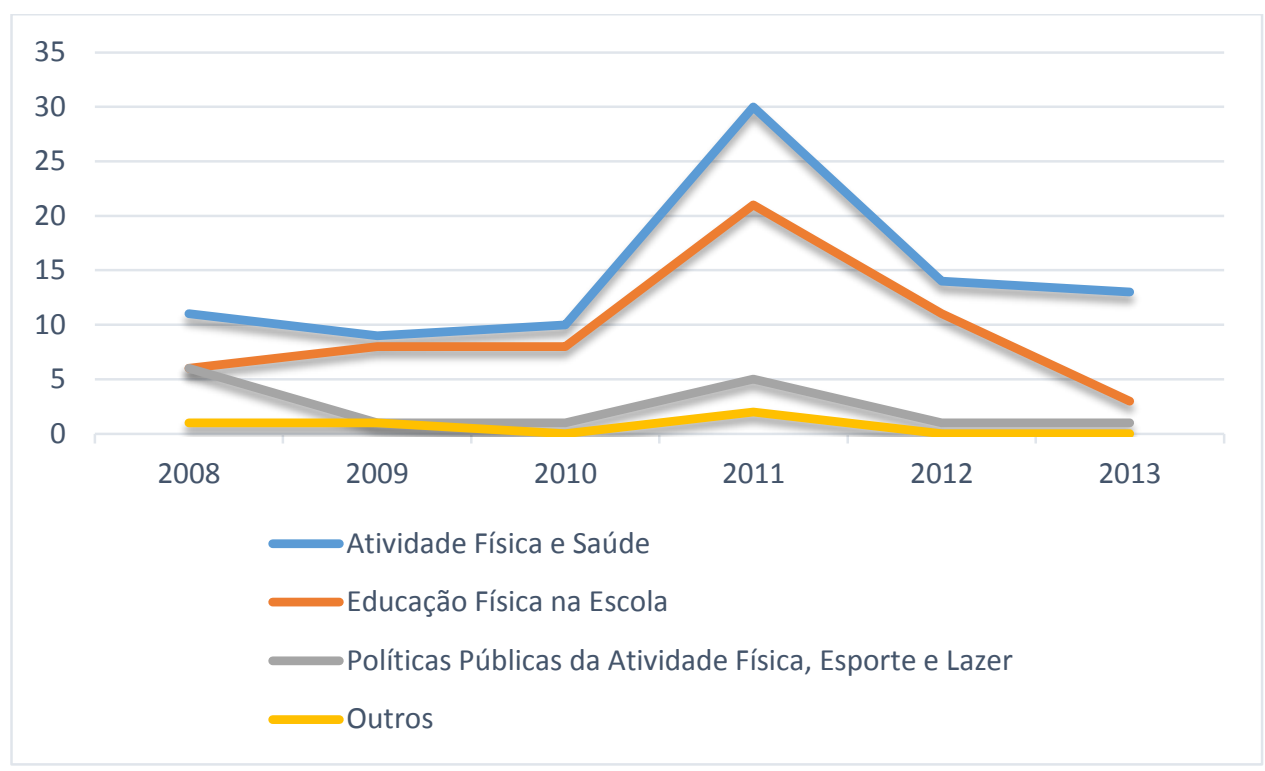

Fonte: próprio autor

Pelos dados apresentados, constatamos uma predominância em todo período de trabalhos voltados para a Atividade Física e saúde. Em continuidade, aparece em segunda ordem de prioridade os trabalhos que analisam a Educação Física na Escola. No período de 2008 a 2013, dos 163 trabalhos produzidos, 87 são ligados à temática Atividade Física e Saúde contra apenas 57 versando sobre a Educação Física na Escola. Em seguida, surgem os trabalhos desenvolvidos em relação às políticas públicas da Atividade Física, Esporte e Lazer que somam 15 no período analisado para, finalmente, aparecer a categoria outras temáticas com 4 trabalhos apenas.

Essa constatação, embora perceptível na maioria dos cursos de licenciatura do nosso país, deve nos preocupar bastante porque expõe a natureza contraditória das licenciaturas ditas ampliadas. O desejo de preparar o aluno para atuar em diversos espaços de atuação profissional, acaba por negar a própria identidade do curso quando analisamos as atuais diretrizes de formação de professores a qual este curso encontra-se embasado.

Outro aspecto é que a superioridade dos trabalhos relacionados à tematica Atividade Física e Saúde remete os alunos a avaliarem a importância da Educação Física como suporte para o desenvolvimento da aptidão física e da saúde em espaços como as Academias, Clubes, 
Unidades Públicas de Saúde, etc, afastando-os dos espaços educacionais que deveriam ser a sua verdadeira, legítima e necessária prioridade. Para nós, a estrutura curricular desempenha um papel fundamental na determinação dos rumos de pesquisa dos alunos, na medida em que assegura a presença num curso de licenciatura de elevado número de disciplinas e professores que desenvolvem esse tipo de abordagem, além do próprio estágio supervisionado ser dividido nas áreas escolar e não escolar. Além disso, temos estruturas derivadas dessa formatação curricular como os grupos de pesquisa, projetos de extensão, atividades acadêmicas, etc, que sensibilizam e estimulam os alunos a pesquisarem nessa perspectiva.

Um outra categoria de análise em nosso estudo sobre os TCCs no curso de Educação Física da UNEB-Campus XII, foi a opção pela abordagem metodológica da pesquisa. Para nós, essa parece ser uma categoria importante e reveladora dos reais propósitos da pesquisa. As principais abordagens na pesquisa são: Empírico-analítica, Fenomenológica e Crítica.

A primeira abordagem se limita ao estudo quantitativo do objeto por meio da experimentação e da observação. Nessa perspectiva de pesquisa, não interessa identificar causas e consequências em torno do objeto estudado. Na segunda abordagem, interessa os dados subjetivos em relação aos fenômenos sociais. Não há preocupação aqui com as generalizações estatísticas. Por último, a abordagem crítica que busca interpretar o objeto a partir das suas características qualitativas e quantitativas além de contextualizar e historicizar as análises (TRIVIÑOS, 1992). Ao analisar as abordagens de pesquisa utilizadas pelos alunos em seus trabalhos de TCC encontramos os resultados conforme o quadro abaixo:

\section{Gráfico III : Abordagem da pesquisa}

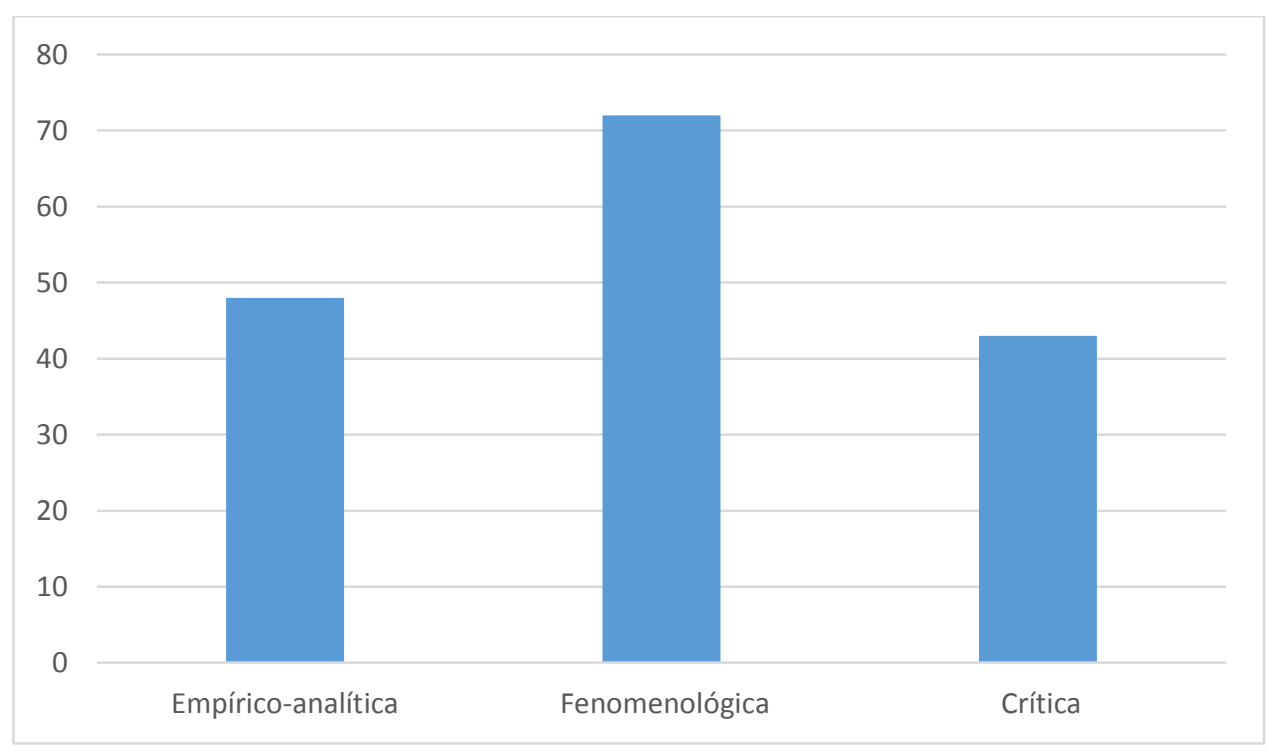

Fonte: próprio autor 
Observamos, portanto, que há uma predominância da abordagem fenomenológica nos trabalhos de conclusão de curso. Esse dado revela que, pelo menos no Curso de Educação Física da UNEB-Campus XII, embora exista uma maior quantidade de trabalhos relacionados com a Atividade Física e Saúde, há uma opção pela abordagem fenomenológica contrariando a tendência de opção pela abordagem empírico-analítica, largamente utilizadas em trabalhos com essa temática.

Verificamos também que a opção pela fenomenologia se deu ao longo de praticamente todo o período estudado com exceção para o ano de 2009 e 2013 quando essa tendência fícou atrás da abordagem empírico analítica. Um dado bastante significativo também é que a abordagem crítica permaneceu como a última opção na maioria do período estudado como podemos observar no quadro abaixo.

\section{Gráfico IV : Abordagem Metodológica da pesquisa}

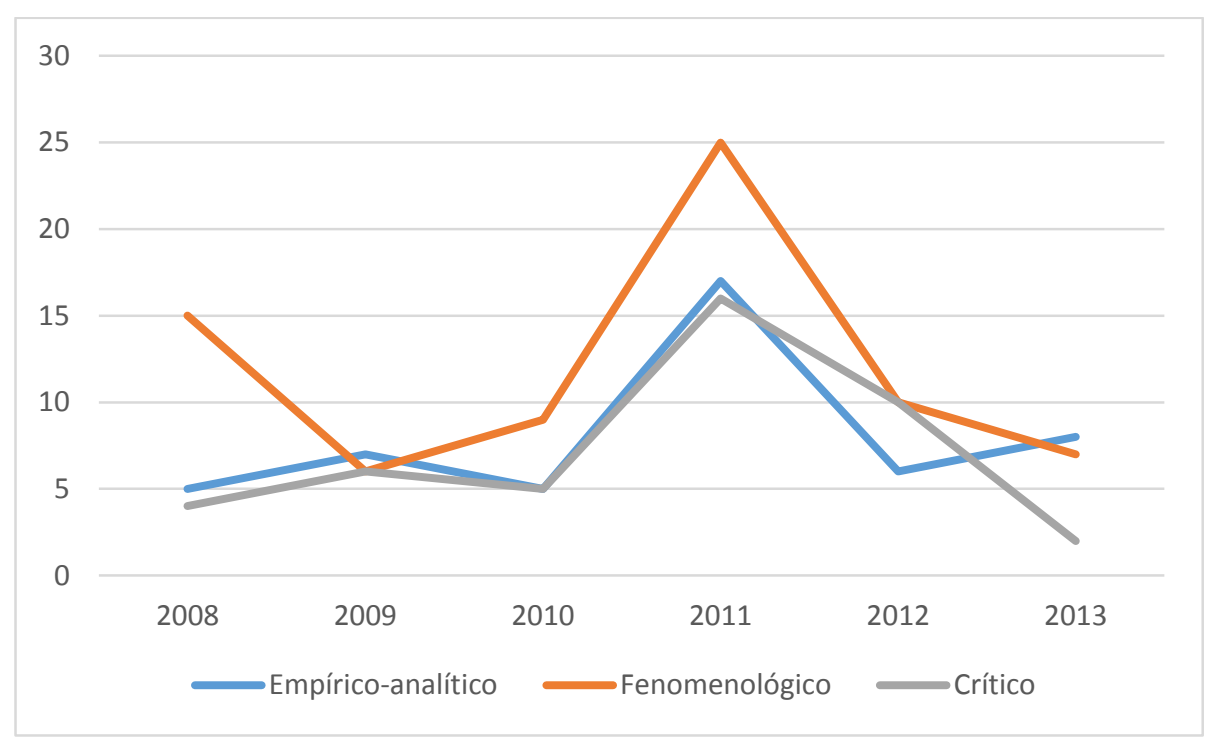

Fonte: próprio autor

Sabemos que a opção por uma ou outra abordagem de pesquisa decorre também da opção pela área de conhecimento que o estudo abrange. Nesse sentido, ao analisarmos os trabalhos, encontramos duas áreas de conhecimento relacionadas. A primeira seria as Ciências da Saúde ou Biomédicas e a segunda as Ciências Sociais e Pedagógicas. Abaixo podemos conferir a vinculação dos trabalhos às referidas áreas de conhecimento. 


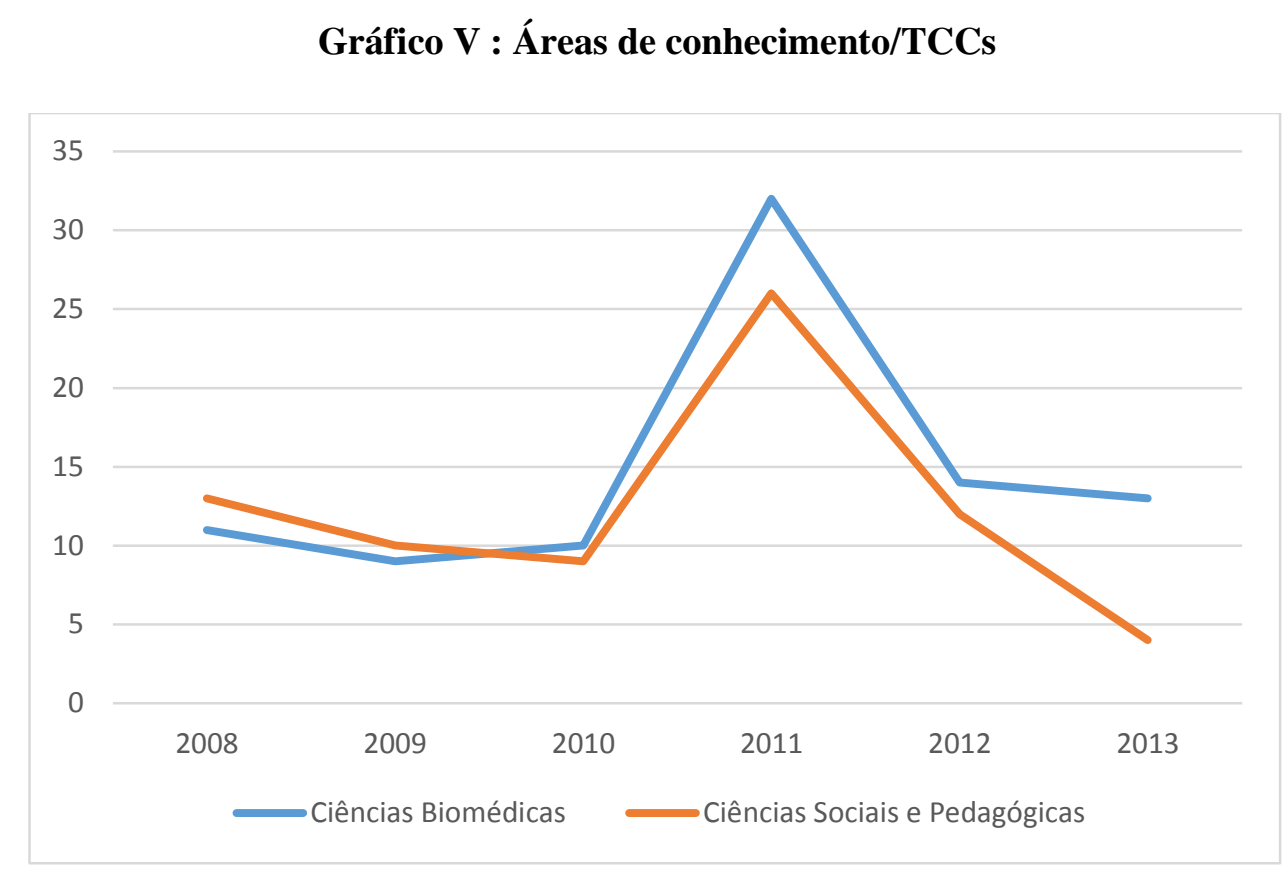

Fonte: próprio autor

Portanto, percebemos que há uma superioridade das ciências biomédicas em relação à produção de conhecimento por meio dos TCCs no período estudado, exceto nos dois primeiros anos. Da mesma forma como observamos em relação à vinculação dos trabalhos às categorias temáticas, a predominância de trabalhos embasados nas ciências biomédicas contraria os objetivos da licenciatura em termos legais além de criar uma identificação profissional relacionada muito mais aos problemas da saúde do que os educacionais. Para nós, trabalhos que tenham como base as ciências biomédicas estariam mais adequadas ao curso de graduação (bacharelado). Contudo, ressaltamos a importância de analisar criticamente os objetos estudados por meio de uma abordagem metodológica crítica.

Tentando provar que as determinações em termos da escolha tanto da temática como da área de conhecimento vinculada ao trabalho sofre fortes influências dos professores, procuramos relacionar a área de conhecimento do trabalho com a área de atuação dos professores no curso. Percebemos que da mesma forma que existe uma prevalência de trabalhos vinculados às ciências biomédicas, há também uma superioridade nessa área em termos da atuação docente no curso, acontecendo da mesma forma nas ciências sociais e pedagógicas. 


\section{Gráfico VI : Relação orientador/ área de conhecimento que atua no curso}

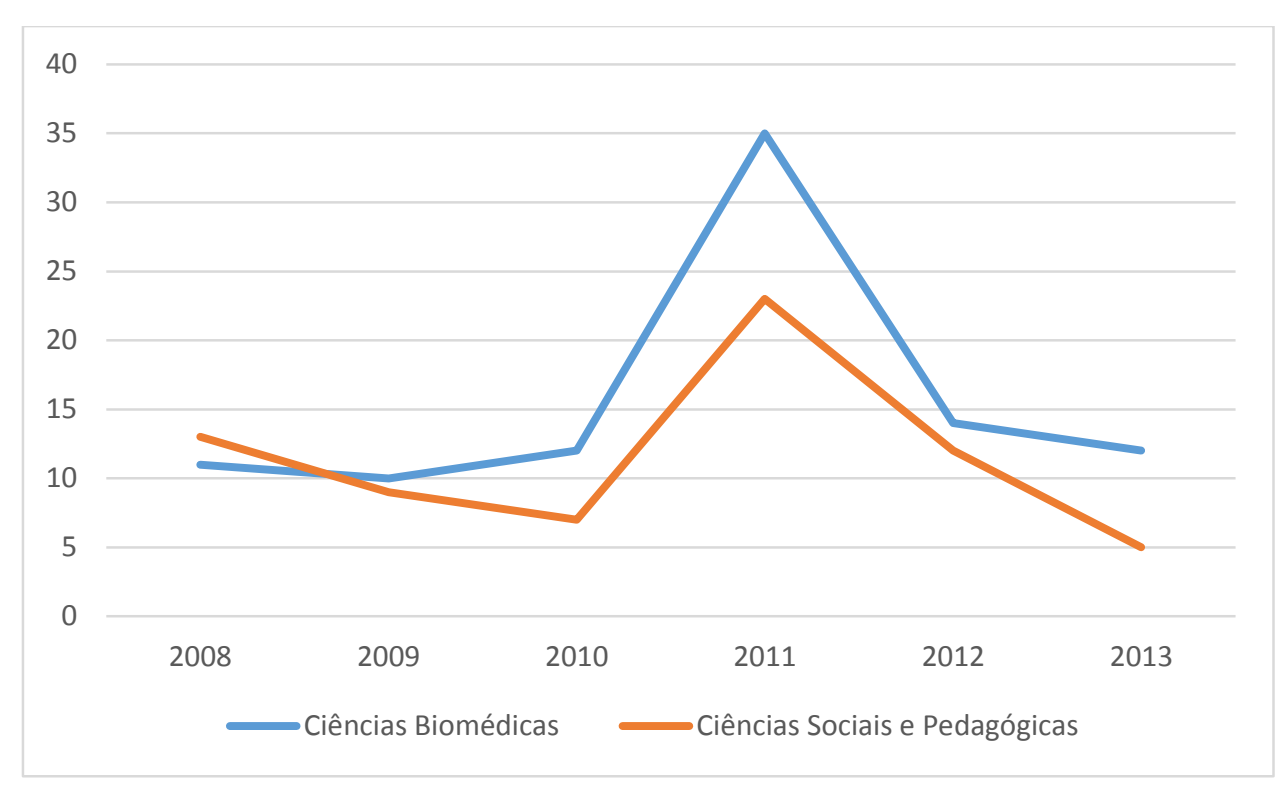

Fonte: próprio autor

O quadro demonstra que há uma predominância em termos da atuação docente nas ciências biomédicas dos professores que participaram em orientações de trabalhos de TCC. Vale ressaltar que isso não significa que existem mais professores das ciências biomédicas no curso, apenas que estão participando mais do processo de orientação talvez em virtude da sua prática pedagógica ou pela preferência dos alunos. É importante frisar que não existia um limite de trabalhos a serem orientados por ocasião da realização dos TCCs, tendo sido ajustado para um total de 05 trabalhos em 2012. Nos dois quadros abaixo, procuramos identificar separadamente a relação entre a área de atuação docente e área de conhecimento dos trabalhos.

Gráfico VII : Área de conhecimento/atuação docente nas ciências biomédicas

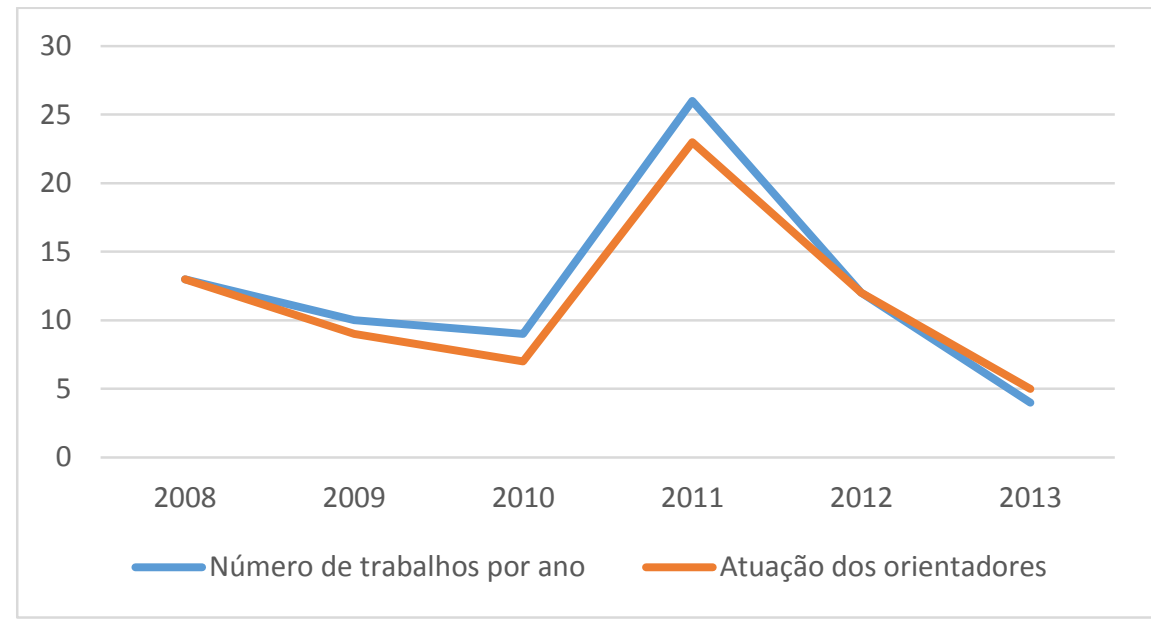

Fonte: próprio autor 


\section{Gráfico VIII : Área de conhecimento/atuação docente nas ciências sociais e pedagógicas}

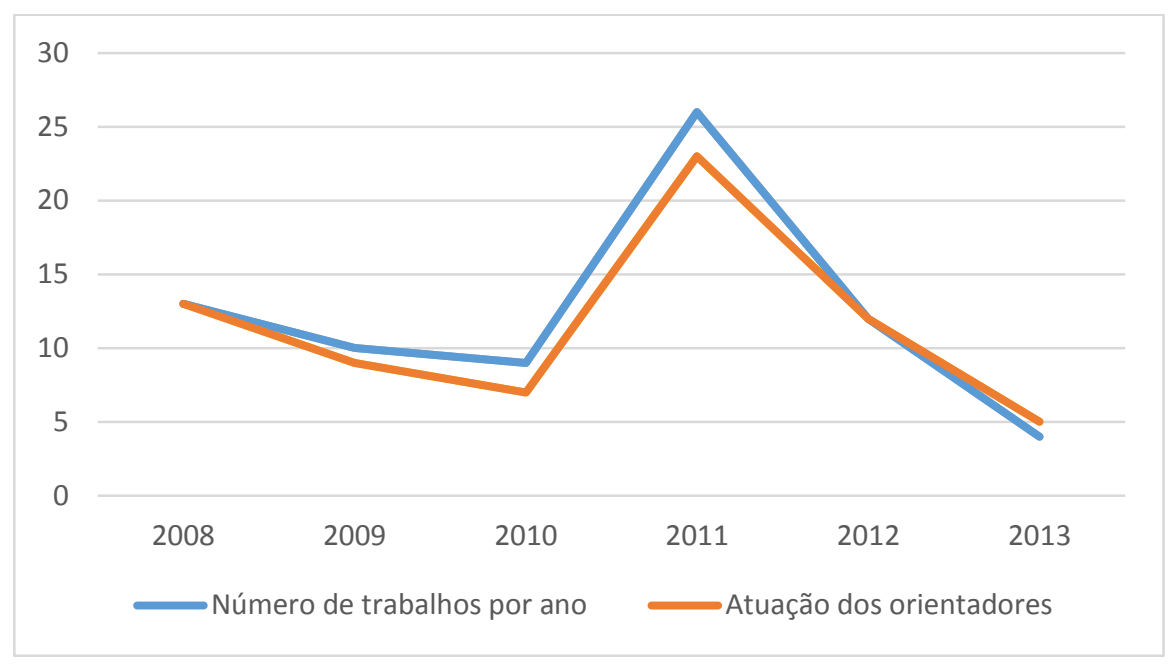

Fonte: próprio autor

O que observamos é que, embora haja um nível de identificação entre a área de atuação docente e área de conhecimento do trabalho, os professores também se dispõem a orientar trabalhos que não se relacionam com a sua área de atuação no curso. Vale destacar que isso ocorre em iguais condições para as duas áreas conforme demonstrado nos quadros em tela.

Outra relação que procuramos analisar no processo de produção de conhecimento por meio dos TCCs é se o nível de formação dos orientadores determina de alguma forma a escolha por uma ou outra área de conhecimento.

Percebemos que devido às condições precárias das Universidades Estaduais, o processo de formação continuada dos docentes, especialmente a pós-graduação stricto sensu é bastante lento. Assim, a participação de professores com maior titulação, sobretudo mestrado e doutorado, é bastante limitada, havendo uma predominância de professores especialistas em todo o período pesquisado conforme podemos perceber no quadro abaixo. Um outro dado importante é que as primeiras orientações no nível de Doutorado só iniciaram no ano de 2011. 
Gráfico IX : Nível de formação dos orientadores

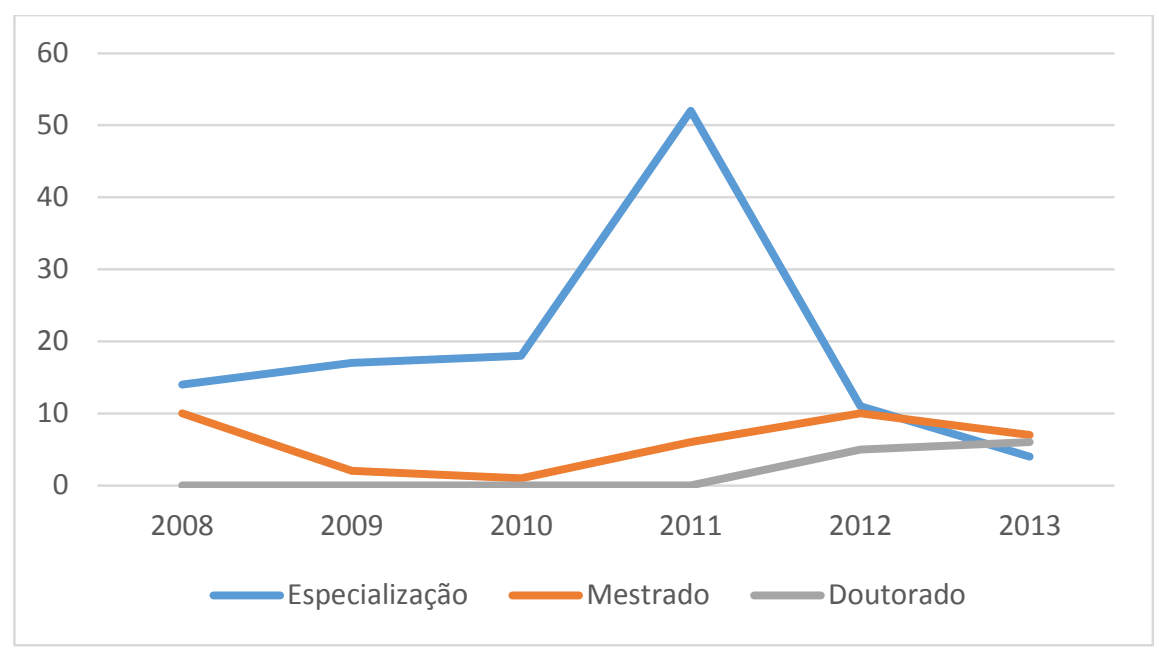

Fonte: próprio autor

No quadro seguinte onde relacionamos o nível de formação com as áreas de conhecimentos verificamos que no nível da especialização e do mestrado, há um equilíbrio entre as áreas de conhecimento vinculadas aos trabalhos. Entretanto, em relação ao Doutorado, percebemos que existe um amplo favoritismo para as ciências biomédicas.

\section{Gráfico X : Nível de formação/Área de conhecimento dos trabalhos de TCC}

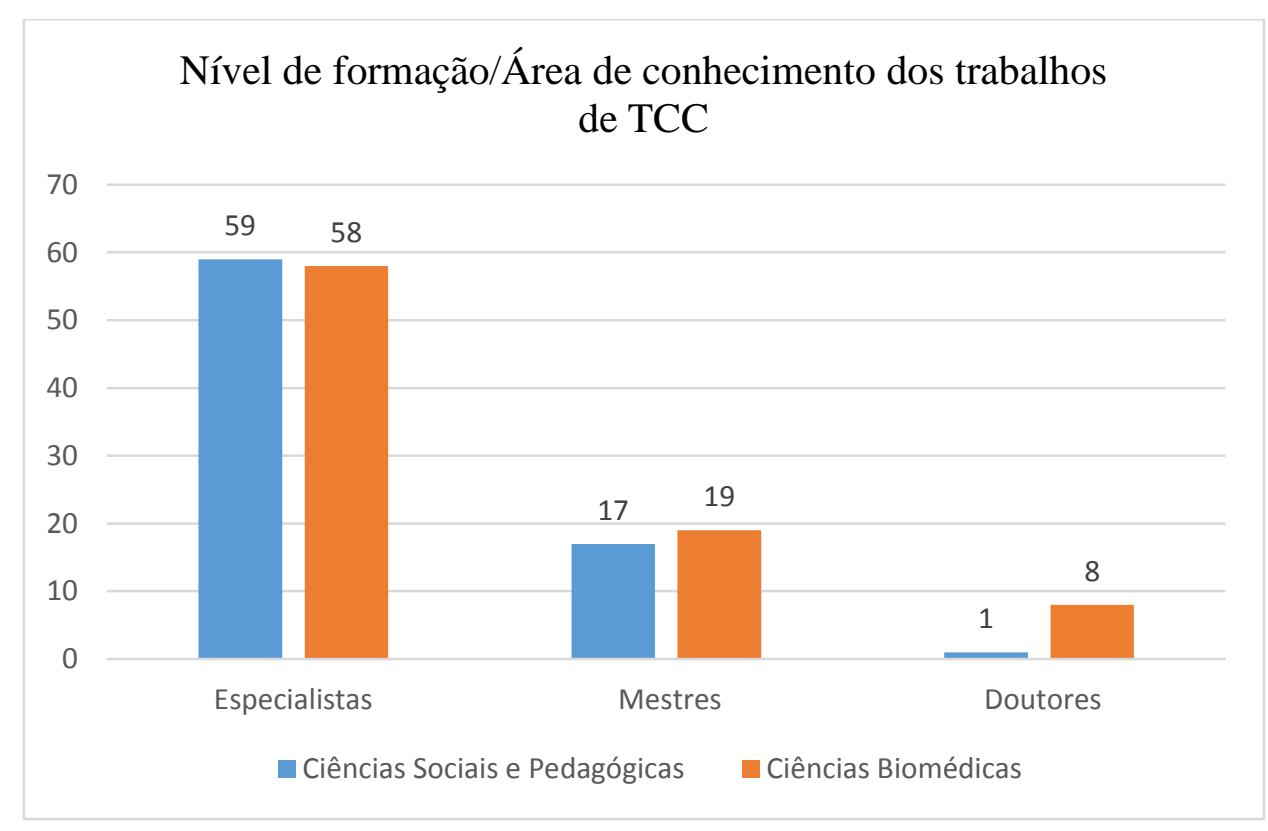

Fonte: próprio autor 
Isso se justifica em virtude dos Doutores que fazem parte do quadro de professores atuarem nessa área e terem se qualificado em programas de pós-graduação vinculados à área de saúde. Isso prova que para além de um currículo crítico, a vinculação do professor a uma ou outra área de conhecimento pode ser determinante na escolha do aluno. Como a licenciatura ampliada abarca todos os conhecimentos e, com isso, absorve profissionais que têm sua inserção em áreas diferenciadas nem sempre ligados à educação, provoca distorções e desvios significativos no processo formativo dos alunos que, ao invés de se debruçarem a conhecer, interpretar e compreender a realidade educacional em que necessitará atuar, acabam por desenvolver estudos completamente distanciados desse contexto.

Portanto, ao finalizar o estudo sobre a produção de conhecimento no curso de Educação Física da UNEB-Campus XII, concluímos que esse processo vêm se dando de forma bastante contraditória e a revelia sobretudo dos aspectos legais a que esse curso está regulamentado. Se acreditarmos que um curso de licenciatura deveria priorizar em seus estudos aspectos relacionados à prática pedagógica da Educação Física, prioritariamente no espaço escolar, perceberemos que o esforço de pesquisa dos acadêmicos do curso encontra-se em direção oposta. O que identificamos foi a hegemonia do campo da saúde no percurso formativo dos alunos concretizados na escolha da área de conhecimento, das temáticas e da abordagem metodológica.

Nesse sentido, urge envidar esforços a fim de avaliar a prática curricular do curso tendo como referência as novas diretrizes curriculares da Educação Física e a perspectiva de uma formação que possa contribuir de fato para uma formação ampliada e consistente, ao contrário da licenciatura ampliada que tem se preocupado mais com as necessidades do mercado de trabalho. Fugir do hibridismo curricular, principal característica desse curso, talvez seja uma tarefa essencial a ser desenvolvida.

Acreditamos ser necessário aprofundar a discussão em torno da ressignificação da formação em Educação Física nesse Campus adotando o modelo em vigor. Percebemos na análise dos TCCs que a maioria dos trabalhos desenvolvidos na área de saúde estão vinculados à saúde coletiva. Portanto, abre-se uma perspectiva importante de criação de um curso de graduação que pense a atividade física como bem comum, distantes do fenômeno da mercadorização tão comum na maioria dos cursos.

Concluímos o capítulo observando que o estudo do projeto curricular e da produção dos TCCs pelos alunos do Curso de Educação Física da UNEB-Campus XII foram feitas a partir da análise documental o que, por certo, nos traz alguns limites na compreensão de determinados aspectos. Portanto, esse estudo contribuiu para a identificação de determinadas contradições no 
currículo, como também para o reconhecimento de avanços na perspectiva curricular. Enfim, abre possibilidades de novos estudos visando o aprofundamento em torno dos aspectos não totalmente elucidados ou apenas parcialmente elucidados nesse trabalho. A nós fica certeza de ter iniciado um processo que visou tão somente instigar a reflexão sobre a formação no interior do curso com vistas à instituição de novos modelos que contribuam mais coerentemente com a formação profissional a partir de princípios humanos e críticos. 


\section{CONSIDERAÇÕES FINAIS}

No início desse trabalho estabelecemos como objetivo geral analisar as repercussões das diretrizes curriculares (Resoluções CNE/CP nº 01 e 02/2002 e Resolução CNE/CES nº 07/2004) sobre a formação profissional em Educação Física, em especial, no curso da UNEB de Guanambi. Para tanto, apresentamos como pressuposto a ideia de que as atuais orientações curriculares, embora rotuladas como uma diretriz neoliberal, podem abrir possibilidades de avanços na formação profissional em Educação Física.

Assim, nossas análises e reflexões buscaram contribuir com novos enfoques, considerando que não há consenso sobre essa temática no cenário acadêmico-científico. Portanto, quando nos aproximamos do final desta caminhada, nos cabe a responsabilidade de sintetizar ideias, reconhecer limites e apresentar sugestões que possam contribuir para o desvelamento dessa importante questão.

Com esse propósito, relacionaremos nossas considerações finais aos objetivos e supostos iniciais a fim de tornar mais compreensível e coerente o esforço de síntese e, por conseguinte, o entendimento do trabalho desenvolvido. Desse modo, destacamos que a defesa da licenciatura ampliada e a negação das atuais Diretrizes Curriculares da Educação Física se dão a partir do argumento de que a nova configuração curricular tem causado a divisão da formação profissional e, consequentemente, a divisão do mercado de trabalho nos âmbitos escolar e não-escolar, estreitando com isso as possibilidades de atuação do profissional da Educação Física.

Ao longo desse estudo, analisamos um número grande de artigos, dissertações, teses, capítulos de livros de autores que analisaram as diretrizes curriculares dando ênfase apenas às determinações econômicas. Quando assim o fizeram correram o risco de analisar superficialmente o objeto, muito embora tivessem dificuldades em aceitar esse prognóstico em virtude de uma determinada apreensão da teoria marxiana. Em nossa opinião, faltou a essas análises mediações com o contexto real, qual seja, os espaços formativos, pois neles podemos extrair outras categorias permissionárias de uma maior aproximação com a essência do objeto estudado.

Por outro lado, é recorrente também a ideia de que a nova configuração curricular proposta pelo CNE e sustentada no modelo de competência, tem em grande monta, pragmatizado e empobrecido a formação, subsumindo o profissional aos interesses do mercado capitalista da Educação Física. Não discordamos da ideia de que o modelo de competências 
utilizado nas Reformas Curriculares pode concorrer para uma formação empobrecida e pragmática dos profissionais não só da Educação Física como de outras áreas. Pelo grande número de leituras feitas ao longo desse trabalho, confirmamos o suposto de que são muito poucos os estudos empíricos em relação aos resultados da formação em Educação Física a partir desse novo modelo curricular instituído pelas Resoluções CNE/CP n ${ }^{\circ} 01$ e 02/2002 e Resolução CNE/CES no 07/2004. Ademais, isso não é exclusividade do marco normativo atual, tendo havido poucas pesquisas sobre os currículos produzidos pela Resolução CFE n ${ }^{\circ}$ 03/87. Assim, não é possível concluir com um grau razoável de fidedignidade, qual o perfil dos alunos que estão sendo formados pelos atuais cursos de Educação Física ou até mesmo comparar entre si os modelos de formação atualmente em vigor, como também deles com os profissionais formados a partir da Diretriz Curricular de 1987.

Desse modo, a questão que se apresenta é que existem margens a partir das Resoluções CNE/CP no 01 e 02/2002 e Resolução CNE/CES 07/2004 para a escolha de competências críticas no processo de formação profissional tanto na licenciatura como nos cursos de Graduação/bacharelado em Educação Física. Isso nos leva a reconhecer que é possível, a partir de um coletivo com ideias progressistas, subverter a lógica técnico-instrumental em nome de uma lógica de apropriação crítica no processo de formação para o trabalho em Educação Física.

Existem possibilidades concretas a partir do novo ordenamento de se estruturar projetos que contribuam para uma formação mais consistente e contextualizada na licenciatura voltada para a atuação docente na Educação Básica. Da mesma forma, a possibilidade de construir projetos de graduação/bacharelado voltados para uma nova compreensão do conhecimento relacionado à atividade física/saúde, desta vez atrelado à saúde coletiva, com inserção em programas públicos que realmente destinem esse conhecimento à população excluída desse direito. Além desse campo de atuação profissional, é possível preparar o profissional da Educação Física para atuar com capacidade técnica e competência política em outros espaços não escolares como a gestão esportiva, o treinamento esportivo, o lazer e outros.

Passemos então a dar foco aos objetivos específicos e as hipóteses inicialmente estabelecidos na tentativa de elucidar aspectos relacionados com as repercussões das Diretrizes Curriculares atuais sobre a formação em Educação Física. O nosso primeiro objetivo específico foi "discutir o processo de constituição e evolução histórica dos currículos de formação profissional em Educação Física no Brasil tendo em vista as orientações e normativas legais". Em relação a essa questão, estabelecemos como hipótese que a formação em Educação Física cumpriu a função de legitimação do modelo de sociedade idealizado pelos governos ditatoriais ao longo do século XX, com forte viés higienista, civico-moralista e esportivista. Pela revisão 
bibliográfica que realizamos no primeiro capítulo, foi possível perceber uma forte influência externa, sobretudo nos períodos ditatoriais ao longo do século XX em nosso país.

Nessa perspectiva, o primeiro modelo curricular foi criado a partir do Decreto-lei $\mathrm{n}^{\circ}$ 1.212, que criou na Universidade do Brasil a Escola Nacional de Educação Física e Desportos. Conforme já especificado no capítulo I desta dissertação, esse modelo de formação profissional em Educação Física e Esporte no Brasil foi moldado com o objetivo de promover o adestramento físico dos jovens brasileiros tendo como finalidade latente, a consolidação do modelo desenvolvimentista de Getúlio Vargas presente no que se convencionou chamar de "Estado Novo".

Ademais, esse modelo contribuiu para “...uma formação de cunho técnico-instrumental, excluindo - mais do que secundarizando - a estruturação de uma sólida base teórica de cunho humanístico (...) o que favoreceu a formação de profissionais acríticos (CASTELLANI FILHO, 2013, p. 18).

Já o segundo modelo curricular foi regulamentado por intermédio do Parecer 894/69 e da Resolução n ${ }^{\circ}$ 69, de 06 de dezembro de 1969, do Conselho Federal de Educação (CFE) ${ }^{35}$, fixando o currículo mínimo dos Cursos de Educação Física.

Novamente com o país mergulhado em uma nova Ditadura e levando-se em conta o contexto autoritário da época, avaliamos que o modelo curricular implantado por essa legislação acabou garantindo os interesses do Estado no que se refere à massificação esportiva e coesão social. Não bastasse o engessamento proporcionado pelo currículo mínimo que não deixava brechas para a diversificação das matérias, as que existiam, promoviam uma formação incipiente, puramente voltada para as questões biológicas e esportivas.

É importante salientar que não houve rupturas entre o primeiro e o segundo modelo curricular para a formação em Educação Física. Destacamos apenas que o segundo modelo se vinculou à Doutrina da segurança nacional com o tripé produtividade, eficiência e eficácia.

O terceiro modelo curricular surgiu em 16 de junho de 1987 com a publicação da Resolução CFE n ${ }^{\circ}$ 03/87 após oito anos de discussões envolvendo toda a comunidade da Educação Física. $\mathrm{O}$ aspecto mais importante dessa normativa foi, seguramente, a autonomia conferida às instituições formadoras para criarem seus próprios currículos, mesmo existindo a SEED -MEC com 5 generais comandando a pasta da educação física e desporto.

Outro aspecto que precisa ser destacado e que foi possível observar nessa pesquisa bibliográfica é que os setores conservadores da Educação Física já anunciavam na década de

\footnotetext{
${ }^{35}$ Betti, 1991, p.114
} 
80 a possibilidade da criação do bacharelado, porém, voltado para a formação do pesquisador, sobretudo nas grandes Universidades. Ao contrário disso, o que se deu a partir da Resolução CFE $n^{\circ}$ 03/87 foi, num pequeno número de universidades a implantação do modelo $3+1$, ou seja, uma base em licenciatura com o último ano do curso sendo dedicado ao aprofundamento nas disciplinas relacionadas com a atividade física, saúde, lazer e esportes fora do contexto escolar.

Confirmamos portanto, a partir da análise histórica, que os currículos de formação em Educação Física cumpriram a função de legitimação do modelo de sociedade idealizado pelos governos ditatoriais ao longo do século $\mathrm{XX}$, com forte viés higienista, esportivista e moralista/patriótico

Em continuidade com o esforço de sintetizar ideias que possam ser válidas para uma melhor compreensão em torno dos problemas que afetam atualmente a formação profissional, destacamos outro objetivo específico que fez parte do nosso trabalho, "refletir sobre a formação profissional a partir de artigos, teses, dissertações e capítulos de livros relacionados com os modelos curriculares orientados pelas Resoluções CFE no 03/87, CNE/CP 01 e 02/2002 e CNE/CES 07/2004".

O nosso foco de análise, a partir desse objetivo, foi tentar captar as principais discussões ou críticas formuladas sobre o currículo de formação antes e depois do atual marco normativo da Educação Física.

Um dos nossos supostos é que a discussão sobre currículo e formação profissional em Educação Física tem apresentado maior ênfase em relação aos aspectos ideopolíticos do que sobre as questões que se referem ao currículo de formação. Por meio do nosso trabalho é possível confirmar isto em virtude da falta de mediações com a prática curricular em seus espaços formativos. A ausência dessas mediações acaba tornando parciais as análises das derivações das atuais diretrizes curriculares sobre a formação em Educação Física, quando toma somente o documento e suas relações com o projeto neoliberal burguês.

Em nosso entendimento, a apropriação dessas normas tem acontecido de forma diferenciada na ambiência formativa, o que não difere dos projetos outrora construídos sob a égide de outras normas. Sabemos que existem cursos de Educação Física em universidades com uma tradição mais crítica e isso, seguramente, foi uma conquista do atores sociais envolvidos. Portanto, não basta apenas analisarmos as diretrizes curriculares identificando seus traços burgueses e, simplesmente, projetar o perfil dos alunos que serão formados a partir da sua vigência. Alertamos que é fundamental incluirmos outras categorias clássicas da análise marxiana da realidade, sobretudo, a mediação, contradição e particularidade do objeto. Com 
isso poderemos identificar outras categorias importantes como já mencionadas e utilizadas nessa pesquisa, para identificar a verdadeira essência dessa questão.

Outro suposto e, agora, conclusão importante desse trabalho, é que ao estabelecer integralidade e terminalidade próprias às licenciaturas, a Resolução $\mathrm{CNE} / \mathrm{CP} \mathrm{n}^{\circ}$ 01/2002 contribui para romper com o antigo modelo dual preconizado pela Resolução CFE n 03/87 conhecido como 3+1 abrindo espaço para o fortalecimento da base de formação do professor.

É necessário também ressaltar que em virtude do carater genérico das Diretrizes de formação de professores, todos os cursos necessitaram construir Resoluções complementares que pudessem explicitar com maior clareza os conhecimentos identificadores da área de conhecimento em questão. Os cursos que possibilitavam atuação fora da escola, como é o caso da Educação Física, acabaram por criar normativas que, além de apresentarem o conhecimento identificador da área, também puderam gerar orientações curriculares para a formação no nível do bacharelado. Assim, entendemos que em virtude das diretrizes de formação de professores determinarem uma formação para atuar na Educação Básica por meio das licenciaturas, houve margens para a criação do bacharelado. Nesse sentido, e pela elucidação dos fatos históricos relacionados com a constituição histórica da Resolução CNE/CES nº 07/2004, é equivocado afirmar que o sistema CONFEF/CREF tenha sido responsável pela divisão da formação em Educação Física.

Também podemos concluir que é falacioso o embate sobre o divórcio entre a diretriz de graduação/bacharelado com a diretriz da licenciatura. Na verdade elas se complementam, sobretudo, a resolução CNE/CES n ${ }^{\circ}$ 07/2004, quando apresenta a especificidade da Educação Física. Portanto, é nessa Resolução que as licenciaturas irão buscar os conhecimentos/conteúdos que deverão se fazer presentes na formação do licenciado. Devemos lembrar que esses são os mesmos conhecimentos a serem tratados na formação do bacharel, entretanto, a diferença reside no grau de complexidade e no enfoque pedagógico de cada conteúdo tendo em vista o contexto de atuação de cada profissional.

Outro aspecto importante que nos dedicamos nesse trabalho foi o de analisar criticamente o processo de constituição histórica das diretrizes curriculares da Educação Física, sobretudo, a Resolução CNE/CES nº 07/2004. Assim, por meio da revisão de artigos, capítulos de livros, teses e dissertações, da transcrição de embates acadêmicos dos profissionais da área sobre este assunto, chegamos à confirmação da hipótese de que parte das análises sobre esse processo apresentam graves contradições, além de um profundo maniqueísmo em que determinados grupos se colocam na condição de defensores dos direitos dos trabalhadores da Educação Física, enquanto situam outros como traidores a serviço do projeto burguês. A partir 
desse processo, parece ter se instalado um embate junto ao segmento crítico da Educação Física sobre a legitimidade das atuais diretrizes, em especial a Resolução CNE/CES nº 07/2004. Com efeito, não é intenção desse trabalho apaziguar o campo da esquerda da Educação Física. Não temos dúvida de que ele estará unido quando as circunstâncias históricas assim exigir. Portanto, parece-nos haver espaço para avançarmos na conquista de uma formação docente capaz de formar seres humanos que possam contribuir para a construção de um mundo mais justo e mais humano.

Em relação à construção da Diretrizes de Graduação em Educação Física, chegamos à constatação de que houve ingerências diversas, tanto no sentido da elaboração de um documento voltado aos interesses de setores conservadores como também de setores progressistas da Educação Física. Nesse sentido, basta compararmos o parecer CNE/CP 138/02 em relação ao o parecer CNE/CES 058/04. São unânimes as opiniões e análises no ambiente acadêmico de que houveram grandes avanços de um para o outro. Isso se deu precisamente em virtude da participação dos diversos coletivos da Educação Física no desmonte do parecer 138/02 e na construção do parecer 058/04, base da Resolução CNE/CES nº 07/2004.

Esses dados e reflexões são importantes, pois nos ajudam a compreender as Diretrizes Curriculares da Educação Física exatamente como elas são, um documento contraditório que expressa conflitos e embates inerentes à correlação de forças políticas em seu processo de elaboração. A contradição nesse caso, não significa demérito ao documento, ao contrário, representa os seus avanços e retrocessos, seus limites e possibilidades e, o principal, o reconhecimento de que a luta está completamente aberta no interior das universidades, faculdades e centros universitários de todo o país no processo de interpretação das diretrizes e da elaboração e execução dos novos currículos. É precisamente nesse espaço que a luta é mais importante e onde a correlação de forças é também desfavorável aos segmentos mais progressistas da Educação Física.

Chamamos atenção também que a luta pela revogação das atuais diretrizes não parece ser uma boa estratégia em virtude dos setores progressistas da Educação Físíca se encontrarem ainda mais frágeis e desarticulados politicamente, dentro de um quadro congressual de índole ainda mais conservadora do que à época da aprovação da Regulamentação da profissão.

Por fim, e chamamos bastante atenção para isso, é necessário compreender que licenciatura ampliada ou unificada não é o mesmo que formação ampliada. A primeira se refere aos campos de intervenção profissional, ou seja, à atuação profissional, e a segunda ao aprofundamento e consistência do processo de formação profissional. Assim, entendemos que a defesa da licenciatura ampliada ou unificada esbarra numa absoluta contradição com aquilo 
que os seus defensores vem pregando. Criticam as diretrizes curriculares com o argumento de que empobreceram a formação pelo seu pragmatismo e acabam se contradizendo na medida em que a licenciatura ampliada ou unificada busca oportunizar uma formação que permita ao egresso atuar no vasto mercado da Educação Física.

Pelo conjunto das análises feitas ao longo desse trabalho a formação em Educação Física vem passando por problemas recorrentes e que ainda não foram superados. As Diretrizes atuais podem, a partir da capacidade crítica dos seus intérpretes, estruturar projetos curriculares que possibilitem a formação de profissionais com capacidade pedagógica e conhecimento para atuar na Educação Básica por meio da Licenciatura e, também, nos diversos outros espaços fora da escola, por meio da Graduação/Bacharelado, tendo sempre como princípio o enriquecimento do sujeito, o desenvolvimento da sua autonomia e a melhoria permanente das suas condições de vida.

Dando prosseguimento ao nosso esforço de síntese, destacaremos mais um dos objetivos específicos do nosso trabalho, "Avaliar consoante o ordenamento legal e o debate sobre a formação profissional, a estrutura e organização curricular do Curso de Educação Física da UNEB de Guanambi." Como primeira hipótese, identificamos que as diretrizes curriculares, a depender do contexto, são apropriadas e materializadas nos projetos curriculares dos cursos de formas diferenciadas. Assim pudemos comprovar esse suposto, tanto quando analisamos o projeto do curso de Educação Física da UNEB como pelas leituras de artigos relacionados com experiências de projetos curriculares em outras universidades. É cada vez maior o número de experiências exitosas na construção de projetos avançados e capazes de contribuir para uma formação mais ampla e sintonizada com as necessidades da sociedade brasileira.

Ainda sobre essa capacidade de apropriação das diretrizes curriculares e, tendo como suporte de análise o projeto do curso de Educação Física da UNEB-Campus XII em GuanambiBA, percebemos que a sua estrutura e organização curricular ficaram condicionadas a outras variáveis, que não se referem ao atual marco legal. O curso, quando redimensionado em 2003, atendeu às orientações emanadas pelas Resoluções CNE/CP n ${ }^{\circ} 01$ e 02/2002 e, na ausência da Resolução CNE/CES n n 07/2004 ainda em processo de discussão, utilizou-se da Resolução CFE $n^{\circ}$ 03/87 para configurar o seu currículo. A partir disso, podemos confirmar mais duas hipóteses. Uma que podem existir tanto aproximações como distanciamentos nos projetos curriculares de cursos de Educação Física em relação às atuais diretrizes curriculares na medida em que, nesse projeto, a estrutura e organização curricular obedecem às orientações das Diretrizes para a formação de professores, entretanto, se distancia dela ao, por exemplo, preparar o aluno para 
atuar tanto na Escola como fora dela, modelo similar aos projetos de cursos previstos pela Resolução CFE nº 03/87.

A outra hipótese é que a licenciatura ampliada atualmente em vigor na UNEB de Guanambi, apresenta uma configuração equivocada, além de estar desamparada legalmente. Afirmamos isso por meio da análise do currículo, identificando uma série de desajustes legais já relatados nesse trabalho, entre os quais destacamos a divisão do Estágio Curricular Obrigatório em duas modalidades quais sejam: Estagio Formal e Não Formal. Esse fato é grave pois em nenhuma parte do texto das Resoluções CNE/CP n ${ }^{\circ} 01$ e 02/2002 está previsto isso. Ao contrário, essas normas dão ênfase à uma formação profissional voltada para a atuação exclusiva na Educação Básica. Assim, nos parece um grande equívoco esse expediente, tanto do ponto de vista pedagógico quanto legal, uma vez que o projeto deveria estar potencializando a formação do professor para atuar na escola e não em espaços extraescolares.

Abaixo, outras conclusões e confirmações de hipóteses relacionadas ao projeto a que chegamos:

1. O curso avança em sua estrutura e funcionalidade, ou seja, a ideia da flexibilidade curricular preconizada pela Resolução CNE/CP No 01/2002, possibilita a estruturação de atividades capazes de produzir o diálogo acadêmico e o conhecimento da realidade, muito embora esteja preso ao processo histórico de fragmentação da área;

2. Que o currículo escrito nem sempre determina o tipo de formação que sofrerá o aluno, uma vez que existem outras variáveis intervinientes no percurso formativo;

3. Que a divisão na formação profissional em Educação Física se dá por dentro do próprio currículo de formação, consubstanciados por práticas de conhecimento e convívio ligados ao campo da saúde em detrimento das áreas sociais e pedagógicas.

4. O currículo se mostra contraditório, às vezes avançando criticamente em relação às competências e perfil profissiográfico, às vezes se adequando ao paradigma da racionalidade técnico-instrumetal;

5. Em virtude do seu hibridismo, não existe uma referência teórica predominante ou hegemônica que embase o processo de formação profissional;

6. Não existe um projeto que oriente as ações político-pedagógicas no processo formativo;

7. O currículo se estrutura, se organiza e se molda com vistas ao atendimento do mercado de trabalho escolar e não escolar;

8. Embora com o discurso da unificação das áreas de atuação profissional, por dentro, o curso se divide e se desarticula em relação ao ensino, pesquisa e extensão. Ao mesmo 
tempo em que propõe um discurso integrador, expõe profundas contradições em sua prática curricular;

Por fim, abordamos o último objetivo específico do nosso trabalho, "Analisar criticamente a produção de conhecimento do Curso de Educação Física da Uneb de Guanambi a partir dos trabalhos de conclusão de curso - TCC." O TCC, embora seja uma experiência preliminar com a pesquisa e com a produção de conhecimento, representa o desfecho das aprendizagens dos alunos ao longo do curso e, nesse sentido, ao delimitarmos esse objetivo, tínhamos como suposto que a produção de conhecimento por meio desse processo apresenta nexos e também contradições com os objetivos de formação do curso e com o que está previsto nas atuais normas para uma licenciatura em Educação Física.

Se tomássemos o projeto do curso, muito embora em desacordo com a Resolução $\mathrm{CNE} / \mathrm{CP} \mathrm{n}^{\circ}$ 01/2002, que prevê objetivos de formação voltados para a atuação na escola e não em outros campos de atuação profissional como aparece neste projeto, teríamos uma expectativa de encontrar TCCs com temáticas distribuídas em igual proporção nos campos escolar e não escolar. Entretanto, pelas análises feitas nesse trabalho, o que podemos constatar é que há uma superioridade de temáticas relacionadas com o campo não escolar, sobretudo, com a atividade física relacionada à saúde. Portanto, isso contraria completamente a justificativa social das licenciaturas que seria contribuir para a melhoria da qualidade da Educação Física na Educação Básica. Também distoa dos objetivos do próprio curso que prevê um equilíbrio entre o estudo dessas temáticas.

Portanto, o que tivemos oportunidade de identificar é que as licenciaturas ampliadas, pelo seu foco na atuação profissional, acaba promovendo uma formação difusa e pouco consistente, estimulando o aluno a conhecer um pouco de um universo muito grande de conhecimentos. Constatamos que esse ecletismo acaba empobrecendo a formação e permitindo que os alunos naveguem por esses conhecimentos e estabeleçam metas próprias de formação que estão relacionadas com o seu imaginário de formação e atuação profissional sem o devido preparo. A produção de conhecimento por meio dos TCCs irá então dar o diagnóstico final em relação à aquisição de conhecimento do aluno ao longo do curso, ou o que ele mais priorizou independente dos objetivos de formação estabelecidos pelo currículo. No caso da UNEB de Guanambi, ao analisarmos a referida produção percebemos que há uma superioridade e trabalhos relacionados com a área da sáude ou do campo de atuação não formal/não escolar. Isso é preocupante porque as atuais diretrizes de formação de professores emanam orientações 
para a construção de currículos que possam qualificar a prática pedagógica dos professores, seja de qual for a área, para atuarem na Educação Básica.

Sabemos que o estudo sobre a formação profissional comporta uma série de análises e se consubstancia como uma atividade bastante complexa como é a própria formação de profissionais das diversas áreas. Nesse trabalho, buscamos refletir sobre as principais questões relacionadas com a formação profissional em Educação Física, muitas delas polêmicas, com uma única preocupação, melhorar a sua qualidade. E quando falamos em qualidade, estamos nos referindo à densidade e à capacidade de intervenção possibilitada pelos nossos cursos de formação em Educação Física aos profissionais gestados em seu interior. É preciso que os currículos construídos a partir das atuais Diretrizes Curriculares contribuam decisivamente para a formação de um profissional crítico, capaz de interpretar a realidade dinâmica do seu tempo, as contradições e necessidades de evolução e transformação social.

Em nosso entendimento, as atuais diretrizes curriculares abrem grandes possibilidades de estruturarmos currículos que possuam essa qualidade, que definam melhor quais os seus verdadeiros e factíveis objetivos de formação. Se pensarmos apenas na atuação profissional, na defesa de uma formação eclética, difusa e confusa para os nossos profissionais, jamais alcançaremos isso. Portanto, o que esteve em jogo o tempo todo em nossas análises foi a formação. Não adianta defendermos uma formação precarizada pensando em atuar em diversas frentes profissionais, mas sem capacidade em termos de conhecimento e de interpretação crítica dessas realidades. A defesa e a luta dos profissionais da Educação Física deveria ser a da melhoria das condições objetivas de trabalho, tanto na escola como em outros espaços como clubes e academias. A verdadeira precarização do trabalhador dessa área profissional tem sido exatamente a sua submissão ao mercado de trabalho, peregrinando em todos esses espaços tornando, assim como a sua formação, difusa e inconsistente a sua atuação profissional.

Em tom de finalização apontamos para a necessidade de novos desdobramentos em relação a esse trabalho. O principal deles seria um estudo mais abrangente e detalhado sobre as diversas realidades brasileiras com a formação em Educação Física a partir das Diretrizes Curriculares atuais. É necessário identificar, no contexto formativo, as principais e reais experiências curriculares construídas por intermédio dessas normas e, o principal, qual tem sido os resultados desse processo formativo. É importante, antes de condenarmos as atuais diretrizes, sabermos concretamente quais as suas possibilidades e limites.

Desta forma, concluímos o nosso trabalho com o sentimento de termos contribuído com as reflexões sobre a formação profissional em Educação Física, sobretudo aquelas que se propõem a pensar os nexos entre as atuais Diretrizes Curriculares da Educação Física e suas 
repercussões com o processo formativo dos milhares de profissionais brasileiros. Reconhecemos a existência de limites e de possíveis imprecisões em nosso trabalho e também de novas direções a serem seguidas o que, por certo, representarão desafios e esforços individuais e coletivos na continuidade das nossas vidas. Concluo com o sentimento de dever cumprido e de ter colocado mais um tijolo nessa complexa edificação chamada formação profissional em Educação Física. 


\section{REFERÊNCIAS BIBLIOGRÁFICAS}

ALVES, Dalton José. A filosofia no Ensino Médio: ambigüidades e contradições na LDB.

ANDRADE FILHO, Nelson Figueiredo de . Formação profissional em educação física brasileira: uma súmula da discussão dos anos de 1996 a 2000. Revista Brasileira de Ciências do Esporte, Campinas - SP, v. 22, n.3, p. 23-37, 2001.

AZEVEDO, A. C. B. ; MALINA, A. . Memória do Currículo de Formação Profissional em Educação Física no Brasil. Revista Brasileira de Ciências do Esporte, Campinas, v. 25, p. 7 160, 2004.

APPLE, Michael W. Ideologia e currículo. São Paulo: Brasiliense, 1982.

ARRUDA, Ana Lúcia Borba de. Expansão da Educação Superior no Brasil e as implicações para a Gestão. 2012. (Apresentação de Trabalho/Conferência ou palestra).

Expansão da Educação Superior: uma análise do Programa de Apoio a Planos de Reestruturação e Expansão das Universidades Federais.

BEHRING, Elaine Rossetti. Política Social no capitalismo tardio. $4^{\text {a }}$ ed., São Paulo: Cortez, 2009.

BERGO, A. C. O positivismo como superestrutura ideológica no Brasil e sua influência na educação. São Paulo: PUC/SP, 1979.

BETTI, Mauro. Perspectivas na formação profissional. In: MOREIRA, W.W. (Org.). Educação Física \& esportes: perspectivas para o século XXI. Campinas: Papirus, 1992.

BRASIL. Lei de Diretrizes e Bases da Educação Nacional n 9.394, de dezembro de 1996. Brasília: Câmara dos Deputados, 1996.

. Lei de Diretrizes e Bases da Educação Nacional nº 4.024, de 20 de dez. de 1961. Brasília: Câmara dos Deputados, 1961.

Lei no 9.696, de $1^{\circ}$ de setembro de 1998. Diário Oficial da União, Brasília, DF, 1998. Brasileira, 1994. [1 edição de 1968).

. Conselho Federal de Educação. Parecer n. 292, 14 nov. 1962. Diário Oficial da União, Brasília, DF, 1962.

Proposta da Política Nacional de Educação Física e Desportos 1986 - 1989” MEC / SEED, 1085b, Brasília, DF, 1986.

Conselho Federal de Educação. Resolução no 03, de 16 de Junho de 1987. Fixa os mínimos de conteúdo e duração a serem observados nos cursos de graduação em Educação Física (Bacharelado e/ou Licenciatura Plena). Diário Oficial da União, Brasília: DF, 10 set. $1987 \mathrm{~b}$. 
. Conselho Nacional de Educação. Câmara de Educação Superior. Resolução CNE/CES 07/2004, Diário Oficial da União, Brasília: DF , 31 de março de 2004.

. Conselho Nacional de Educação. Parecer CNE/CP 09/2001, Diário Oficial da União, Brasília: DF, 08 de maio de 2001.

. Conselho Nacional de Educação. Parecer CNE/CP 138/2002, Diário Oficial da União, Brasília: DF, 03 de abril de 2002.

Conselho Nacional de Educação. Resolução CNE/CP 01/2002, Diário Oficial da União, Brasília: DF, 18 de fevereiro de 2002.

. Conselho Nacional de Educação. Resolução CNE/CP 02/2002, Diário Oficial da União, Brasília: DF, 19 de fevereiro de 2002.

. Conselho Nacional de Educação/Câmara de Educação Superior. Parecer CNE/CES n. 0058, Diário Oficial da União, Brasília: DF, 18 de fevereiro de 2004.

. Presidência da República. Decreto Presidencial n 3.276, de 06 de dezembro de 1999. Diário Oficial da União, Brasília, 07 dez. 1999. Disponível em <http:// www. presidencia. gov.br/ccivil_03 /decreto/D3276.htm>. Acesso em: 13 jul.2006.

Presidência da República. Decreto $n^{\circ}$ 6.755, que institui a Política Nacional de Formação de Profissionais do Magistério da Educação Básica. Diário Oficial da União, Brasília, DF, 29 de janeiro de 2009.

BRAUNER, Vera Lúcia Pereira ; MULLER, Flávio . Professor José: vivências e reflexões sobre uma formação em educação física. Movimento (Porto Alegre), Porto Alegre, v. ano V, n.no 10 , p. 21-25, 1999.

BURBULES, Nicholas C. Uma gramática da diferença: algumas formas de repensar a diferença e a diversidade como tópicos educacionais. In: GARCIA, R L.; MOREIRA, A. F. B. (Orgs). Currículo na contemporaneidade: incertezas e desafios. São Paulo: Cortez, 2003.

CALDEIRA, A. M. S. . Formação de Professores de Educação Física; quais saberes quais habilidades?. Revista Brasileira de Ciências do Esporte, CAMPINAS/CBCE e Autores Assoc., v. 22, n.3, p. 87-103, 2001. Campinas/SP: Autores Associados, 2002. 170 p.

CARVALHO, Olgamir Francisco de. Educação e formação profissional - trabalho e tempo livre. Brasília: Plano Editora, 2003. 176p.

CASTEllani filho, Lino e CARVAlho, Yara Maria de. In: CASTRO, Adriana e MALO, Miguel (Orgs.). SUS ressignificando a promoção da saúde. São Paulo: Hucitec, 2006.

CASTELlANI FILHO, Lino. Educação Física, esporte e lazer: reflexões nada aleatórias. Campinas, SP: Autores e Associados, 2013.

Formação Em Educação Física No Âmbito da Educação Superior Brasileira: Aproximações ao Cenário Sulamericano. In: Almeida, Maria de Lourdes Pinto de; Catani, 
Afrânio. (Org.). Políticas de Educação Superior na América Latina. Rio de janeiro - RJ: Editora Mercado das Letras, 2011, v. 1, p. -.

Educação Física no Brasil: a história que não se conta. Campinas: Papirus, 1988. $224 \mathrm{p}$.

CORBUCCI, Paulo Roberto. Financiamento e democratização do acesso à educação superior no Brasil: da deserção do Estado ao projeto de reforma. Educação e Sociedade, São Paulo: Cortez, v.25, n.88, p.681-696, out.2004.

CORRÊA, Denise A. Ensinar e aprender educação física na "Era Vargas": lembranças de velhos tempos de professores. In: VI EDUCERE - Congresso Nacional de Educação - PUCPR - PRAXIS, 2006, Curitiba.

COSTA, A. S. F. . A Produção Científica relacionada com a temática "formação de professores" na Revista Brasileira de Ciências do Esporte: 1979 a 2003. In: Zenólia Cristina Campos Figueiredo. (Org.). Formação Profissional em Educação Física e Mundo do Trabalho. 1ed.Vitória: Editora da Faculdade Salesiana de Vitória, 2005, v. 1, p. 237-265.

DANTAS JUNIOR, H. S. . A esportivização da Educação Física no século do espetáculo: reflexões historiográficas. Revista HISTEDBR On-line, v. 29, p. 215-232, 2008.

DAVID, Nivaldo A. Nogueira. Novos Ordenamentos Legais e a Formação de Professores de Educação Física: pressupostos de uma nova Pedagogia de Resultados. 2003. 128 f. (Dissertação de Mestrado) Universidade Estadual de Campinas (UNICAMP). Campinas: 2003.

Formação de Professores para a Educação Física: Dilemas Atuais para a Educação Física . Revista Brasileira de Ciências do Esporte, Autores Associados, v. 23, n.2, p. 119-133, 2002.

DELORS, Jacques. Educação: um tesouro a descobrir --- Relatório para a UNESCO da COMISSÃ̃ Internacional sobre Educação para o Século XXI), São Paulo, Cortez Editora, 1998.

DIÁRIO DA ASSEMBLÉIA NACIONAL CONSTITUINTE. Anais do Senado Federal e Publicações Oficiais da Câmara dos Deputados. Disponível na Internet via www.senado.gov.br e www.camara.gov.br. Acessos: acesso em novembro de 2013.

DUARTE, N. . Conhecimento tácito e conhecimento escolar na formação do professor (Porque Donald Schön não entendeu Luria). Educação e Sociedade, Campinas-SP, v. 24, n.83, p. 601626, 2003.

DUSSEL, Inés. O currículo híbrido: domesticação ou pluralização das diferenças? In: LOPES, Alice R. C. e MACEDO, Elizabeth (Orgs.) Currículo: Debates Contemporâneos. São Paulo: Cortez, 2002, p.55-77.

DUNNING, E. A dinâmica do desporto moderno: notas sobre a luta pelos resultados e o significado social do desporto. In: ELIAS, N. A busca da excitação. Tradução: Maria Manuela Almeida e Silva. Lisboa: Difel, 1992. p. 299- 325. 
FARIA JUNIOR, A. G. Professor de educação física, licenciado generalista. In: OLIVEIRA, V. M. de (Org.). Fundamentos pedagógicos da educação física. Rio de Janeiro: Ao Livro Técnico, 1987, p. 11-33.

Reflexões sobre a Educação Física Brasileira: a carta de Belo Horizonte. Revista Brasileira de Ciências do Esporte, v. 23, n. 1, p. 19-31, set. 2001.

FERNANDES, Florestan. Nova República? Rio de Janeiro: Zahar, 1986.

FIGUEIREDO, Z. C. C. . Formação Docente em Educação Física: experiências sociais e relação com o saber. Movimento (UFRGS. Impresso) Porto Alegre UFRGS, v. 10, p. 89-112, 2004.

FIGUEIREDO, Z. C. C. . Uma Experiência de Formação de Professores de Educação Física na Perspectiva do Formar-se Professor. Pensar a Prática (UFG), v. 12, p. X-X, 2009.

FIGUEIREDO, Z. C. C. ; MARQUES, F. B.. Diretrizes Curriculares Nacionais para os Cursos de Educação Física: fronteiras entre orientações e aprisionamentos legais. $<$ http://cbce.tempsite.ws/congressos/index.php/conbrace2013/5conice/paper/viewFile/5 $\underline{052 / 2819>}$. Acesso em 08 agosto 2013.

FIGUEIREDO, Z. C. C. ; MORAIS, E. A. L. . Histórias de vida e de aprendizagem da docência de professores de um curso de Licenciatura em Educação Física. Pensar a Prática (UFG. Impresso), v. 16, p. 54-68, 2013.

FRIGOTO, Gaudêncio. Educação e formação humana: ajuste neoconservador e alternativa democrática. In: GENTILI, Pablo, SILVA, Tomaz Tadeu da (Orgs). $7^{\mathrm{a}}$ ed. Neoliberalismo, qualidade total e educação: visões críticas. Petrópolis, RJ: Vozes, 1999. p. 33-92.

FRIGOTTO, G. . Reformas educativas e o retrocesso democrático no Brasil nos anos 90.In: LINHARES, Célia (Org.). Os professores e a reinvenção da escola. Brasil e Espanha. São Paulo: Cortez, 2001. Cap II. p. 57-80.

GALVÃO, A. . O neoliberalismo na perspectiva marxista. In: $5^{\circ}$ Colóquio Internacional Marx e Engels, 2007, Campinas. $5^{\circ}$ Colóquio Internacional Marx e Engels, 2007. 64 ${ }^{\mathrm{a}}$ REUNIÃO ANUAL DA SOCIEDADE BRASILEIRA PARA O PROGRESSO DA CIÊNCIA. Mesaredonda organizada pelo CBCE intitulada Formação profissional em Educação Física: uma antítese que se arrasta... Maranhão, São Luis: UFMA, 2012. Disponível em: https://www.youtube.com/watch?v=WJDxzkvLN14\&list=UUDsdj4NGukumVZ_zpT9bF_w \&index=1\&feature=plcp Acesso em: 17/03/2014.

GIL, A. C. Como Elaborar Projetos de Pesquisa. 4ª ed., São Paulo: Atlas, 2007.

GOMES, Alfredo Macedo. As Reformas e Políticas da Educação Superior no Brasil: avanços e recuos. In: MANCEBO, Deise; SILVA JÚNIOR, João do Reis; OLIVEIRA, João Ferreira (Org.). Reformas e políticas: educação superior e pós-graduação no Brasil. Campinas: Alínea, 2008.

GRAMSCI, Antonio. Cadernos do cárcere - Introdução ao Estudo da Filosofia. A Filosofia de Benedetto Croce. Rio de Janeiro: Civilização Brasileira, 1999. 494 p. v. 1. 
HARVEY, David (1992) Condição pós-moderna - Uma Pesquisa sobre as Origens da Mudança Cultural, Edições Loyola: São Paulo.

IANNI, Octavio. O colapso do populismo no Brasil. 5. ed. Rio de Janeiro: Civilização

KUENZER, A. Z. (org.) Ensino médio: construindo uma proposta para os que vivem do trabalho. São Paulo: Cortez, 2000. Parte I, p. 25-90.

KUNZ, E. et ali. Novas diretrizes curriculares para os cursos de graduação em Educação Física: justificativas - proposições - argumentações. Revista Brasileira de Ciências do Esporte, Campinas, v. 20, n. 1, p. 37-47, set. 1998.

LOPES, Alice R. C. Parâmetros curriculares para o ensino médio: quando a integração perde seu potencial crítico. In: LOPES, Alice C.; MACEDO, Elizabeth (Org.). Disciplinas $e$ integração curricular: história e políticas. Rio de Janeiro: DP\&A, 2002. p. 145-176.

. Política de currículo: recontextualização e hibridismo. Currículo sem Fronteiras, v. 5, n. 2, p. 50-64, jul./dez. 2005. Disponível em: <www.curriculosemfronteiras.org>. Acesso em: 30 jan. 2007.

Políticas de integração curricular. Rio de Janeiro: Ed. da UERJ, 2008.

LUKACS, G. Historia e consciencia de classe. Trad. Telma Costa. Porto : Escorpiao, 1974.

MANDEL, Ernest. A crise do capital: os fatos e sua interpretação marxista. São Paulo: Ensaio; Campinas: Ed. UNICAMP, 1990.

MARINHO, Inezil Penna. História da educação física e desportos no Brasil. Rio de Janeiro: DEF-MES, 1952 .

MARX, K. . Contribuições à crítica da economia política. $2^{a}$ ed. São Paulo: Martins Fontes, 1983.

MELO, Victor Andrade de. Dissertação de mestrado sob o título, "Escola Nacional de Educação Física e Desportos - Uma Possível História". Campinas - SP: UNICAMP, 1996

MÉSZÁROS, István. A crise do capital. São Paulo: Boitempo, 2009.

A crise estrutural do capital. In: Outubro. no. 4. São Paulo: Xamã, março, 2000.

MOLINA NETO, V. . A formação profissional em educação física e esportes.. Revista Brasileira de Ciências do Esporte, v. 19, p. 34-41, 1997.

MOCKER, Maria Cecília de Miranda. Currículo e formação profissional em Educação Física: algumas reflexões. Campinas, SP: RBCE, 1993, p. 60-64.

NÓVOA, António. Profissão professor. Portugal: Porto Editora, 1991.

NOZAKI, HajimeTakeuchi. Educação Física e reordenamento no mundo do trabalho: mediações da regulamentação da profissão. 2004. 383f. Tese (Doutorado em Educação)Faculdade de Educação, Universidade Federal Fluminense, Rio de Janeiro, 2004. 
OHNO, Taiichi. O sistema toyota de produção: além da produção em larga escala. Porto Alegre: Bookman, 1997. Trad. Cristina Schumacher.). ix-35.

PAIVA, F. S. L. ; ANDRADE FILHO, Nelson Figueiredo de ; FIGUEIREDO, Z. C. C. . Formação Inicial e Currículo no CEFD/UFES. Pensar a Prática (UFG), v. 9, p. 213-230, 2006.

PARASKEVA, J. M. Currículo como prática (regulada) de significações. In: Paraskeva, J. M. (Org.). Educação e poder: abordagens críticas e pós-estruturais. Porto: Edições Pedago. 2008, p. 135-168.

PAUlO NETTO, J. . Introdução ao estudo do método de Marx. 1. ed. São Paulo: Expressão Popular, 2011. v. 1.

PEREIRA FILHO, E. S. Educação Física: limites da formação e exercício profissional. In: Figueiredo, Zenólia. (Org.). Formação Profisional em Educação Física e Mundo do Trabalho. $1^{a}$ ed. Vitória-ES: Faculdade Salesiana de Vitória, 2005, v. 1, p. 47-69.

RANGEL, I. C. A. ; GALVÃO, Zenaide . Ensino reflexivo em uma experiência no ensino superior em Educação Física. Revista Brasileira de Ciências do Esporte, São Paulo, v. 22, n.3, p. 105-116, 2001.

RODRIGUES, A. T. . A questão da formação de professores de educação física e a concepção de professor enquanto intelectual-reflexivo-transformador. Pensar a Prática (UFG), Ed. da UFG - Goiânia - GO, v. 1, p. 48-58, 1998.

ROMANELLI, Otaíza de Oliveira. História da educação no Brasil. 6.ed. Rio de Janeiro: Vozes, 1984.

SANTOS, Boaventura de Sousa. A universidade no século XXI: para uma reforma democrática e emancipatória da universidade. São Paulo: Cortez, 2004.

SÃO PAULO. SECENP. Educação Física. Legislação Básica (Federal e Estadual). Org. e comp.de Leslie Maria José da Silva Rama e José Álvaro Pereira dos Santos. São Paulo, Secenp, 1985.

SÁ-SILVA, Jakson Ronie; ALMEIDA, Cristovão Domingos de; GUINDANI, Joel Felipe. Pesquisa documental: pistas teóricas e metodológicas. In: Revista Brasileira de História e Ciências Sociais, ano I, nº 1, jul./2009. Rio Grande do Sul: Feevale, 2013.

SAVIANI, D. Escola e Democracia. São Paulo: Cortez Autores Associados, 1983.

SCHEIBE, L. ; BAZZO, V. L. . Políticas governamentais para a formação de professores na atualidade. Revista Brasileira de Ciências do Esporte, Campinas, v. 22, p. 9-21, 2001.

SCHNEIDER, M. P. . Diretrizes Curriculares Nacionais para a formação dos profissionais da educação básica: o currículo integrado em questão. Educação (UFSM), v. 00, p. 316, 2007.

SHIROMA, E. O. et al. Política educacional. Rio de Janeiro: DP\&S, 2000.

SILVA JR., João dos Reis, SGUISSARDI, Valdemar. Novas faces da educação superior no Brasil: reforma do estado e mudanças na produção. $2^{a}$ ed. rev. Bragança Paulista, SP: Cortez, 2001. 
SILVA JR., J. dos R. Reforma da educação superior: a produção da ciência engajada ao mer cado e de um novo pacto social. In: DOURADO, L. F.; CATANI, A. M.; OLIVEIRA, J. F. de. (orgs.). Políticas e gestão da educação superior: transformações recentes e debates at uais. São Paulo: Xamã; Goiânia, Alternativa, 2003, p. 53-80.

SILVA, João Bosco da. Análise das relações existentes na legislação que orienta a formação profissional dos especialistas em Educação Física e Desportos e os planos nacionais nas áreas educacional e desportiva do Brasil. (Dissertação de Mestrado) Universidade de São Paulo (USP). São Paulo: 1983.

SOUZA NETO, S. ; ALEGRE, Atilio de Nardi ; HUNGER, Dagmar ; PEREIRA, Juliana Martins . A formação do profissional de Educação Física no Brasil: uma história sob a perspectiva da legislação federal no século XX. Revista Brasileira de Ciências do Esporte, Campinas, v. 25, n.2, p. 350-362, 2004.

SOARES, Carmen. Educação física, raízes européias no Brasil. Campinas: Autores Associados, 1994.

STECANELA, Nilda ; THOMÉ, Regina . A construção do professor reflexivo: um esntudo sobre os indicadores de simetria invertida. In: XV Encontro de Jovens pesquisadores da UCS, 2007, Caxias do Sul. Anais do XV Encontro de Jovens Pesquisadores da UCS, 2007.

TAFFAREL, C. N. Z. ; LACKS, S. . Diretrizes curriculares: Proposições superadoras para a formação humana. In: Zenólia Chistina Campos Figueiredo. (Org.). Formação profissional em educação física e mundo do trabalho. Vitória: Gráfica da Faculdade Salesiana da Vitória, 2005, v. 01, p. 89-110.

TAFFAREL, C. N. Z. e SANTOS JÚNIOR, C. de L. Formação Humana e Formação de Professores de Educação Física: Para Além da Falsa Dicotomia Licenciatura X Bacharelado. In: Formação em Educação Física \& Ciências do Esporte: Políticas e Cotidiano. TERRA, D. V. e SOUZA JÚNIOR, M. São Paulo: Aderaldo \& Rothschild. Goiânia, GO: CBCE. P13-47, 2010.

Nexos e determinações entre formação de professores de educação física e diretrizes curriculares: competências para quê?. In: Zenólia Chistina Campos Figueiredo. (Org.). Formação profissional em educação física e mundo do trabalho. Vitória: Gráfica da Faculdade Salesiana de Vitória, 2005, v. 01, p. 111-136.

TAFFAREL, C. N. Z.. Resenha sobre o trabalho acadêmico intitulado Formação acadêmica para atuação profissional no campo de trabaho da Educação Física em São Luiz/MA: estudo de caso de egressos mais críticos do curso de Educação Física da Universidade Federal do Maranhão. Campinas, SP: RBCE, 1990, p. 241.

TOJAL, João Batista. Currículo de Graduação em Educação Física: a busca de um modelo. Campinas, SP: UNICAMP, 1989.

TORRES SANTOMÉ, Jurjo. Globalização e interdisciplinaridade - o currículo integrado. Porto Alegre: Artes Médicas, 1998.

TRIVIÑOS, Nibaldo Silva. Introdução à pesquisa em ciências sociais: a pesquisa qualitativa em educação. São Paulo: Atlas, 1992. 
TUMOLO, Paulo Sérgio. A política nacional de formação sindical da central única dos trabalhadores diante do novo padrão de acumulação de capital. São Paulo, 1998. Tese (Doutorado em Educação: História e Filosofia da Educação). PUC/SP. p. 10-66.

Trabalho: categoria sociológica chave e/ou princípio educativo? O trabalho como princípio educativo diante da crise da sociedade do trabalho. Revista do Centro de Ciências da Educação da UFSC. Trabalho e educação: um olhar multirreferencial. Florianópolis, SC: Editora da UFSC, n. 26, p. 39-70, jul./dez. 1996.

Reestruturação produtiva no Brasil: um balanço crítico da produção bibliográfica. Florianópolis, SC, 1999.

UNIVERSIDADE DO ESTADO DA BAHIA. Projeto de Redimensionamento do Curso de Educação Física do Campus XII. Guanambi, 2004.

VENTURA, P. R. V. A. Educação Física e sua Constituição Histórica - Desvelando Ocultamentos, Ano de obtenção: 2010.

ZARIFIAN, Philippe. O modelo de competência: trajetória histórica, desafios atuais e propostas. São Paulo: SENAC São Paulo, 2003. 